\title{
ॠUSGS
}

science for a changing world

Prepared in Cooperation With the North Carolina Geological Survey

\section{Detailed Sections From Auger Holes in the Elizabethtown 1:100,000-Scale Quadrangle, North Carolina}

By Robert E. Weems, William C. Lewis, Joseph H. Murray, David B. Queen, Jeffrey B. Grey, and Benjamin D. DeJong

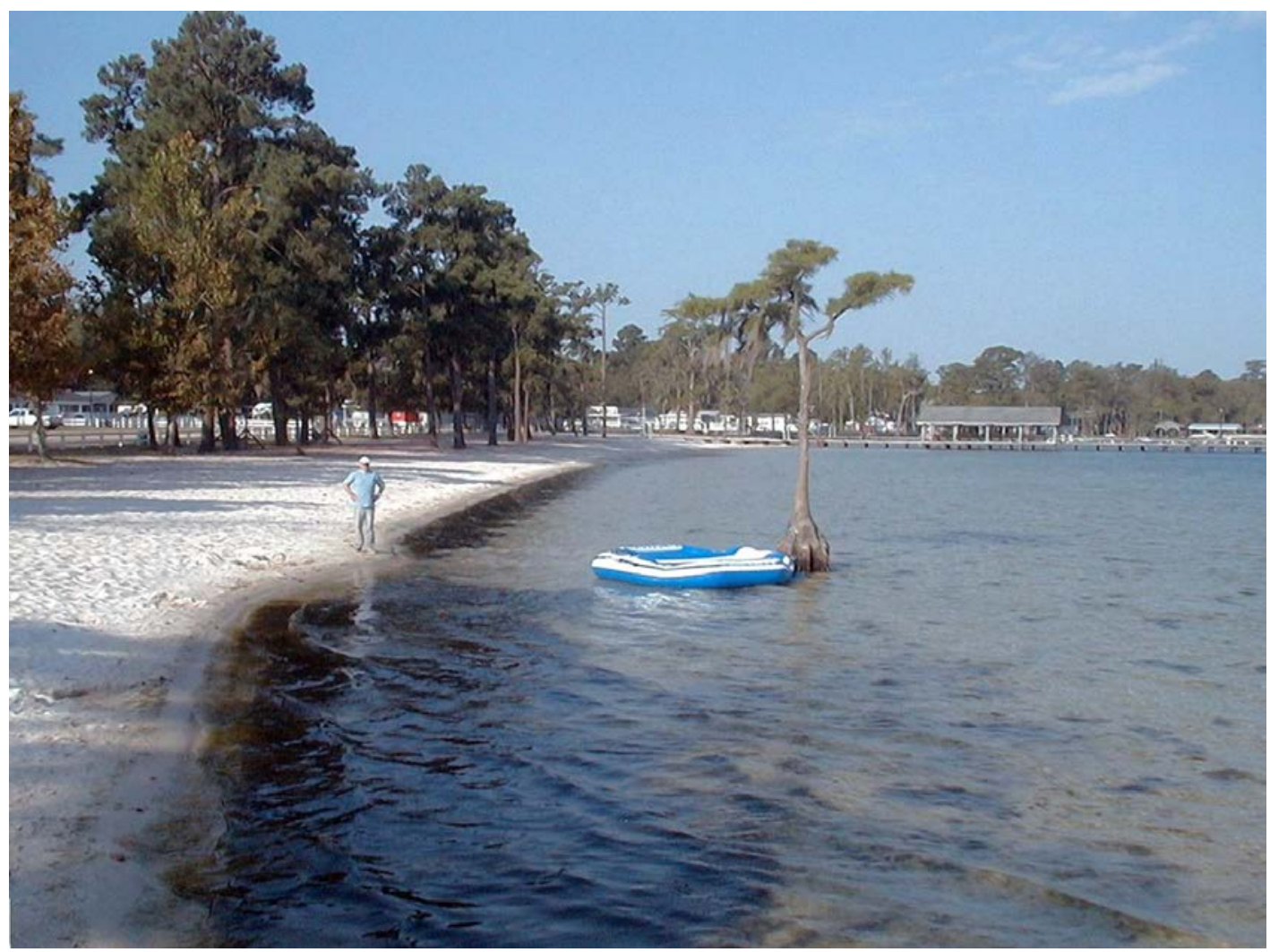

Open-File Report 2011-1115 


\section{U.S. Department of the Interior \\ KEN SALAZAR, Secretary}

\section{U.S. Geological Survey \\ Marcia K. McNutt, Director}

U.S. Geological Survey, Reston, Virginia: 2011

For product and ordering information:

World Wide Web: http://www.usgs.gov/pubprod

Telephone: 1-888-ASK-USGS

For more information on the USGS-the Federal source for science about the Earth,

its natural and living resources, natural hazards, and the environment:

World Wide Web: http://www.usgs.gov

Telephone: 1-888-ASK-USGS

Suggested citation:

Weems, R.E., Lewis, W.C., Murray, J.H., Queen, D.B., Grey, J.B., and DeJong, B.D., 2011, Detailed sections from auger holes in the Elizabethtown 1:100,000-scale map sheet, North Carolina: U.S. Geological Survey Open-File Report 2011-1115, 286 p.

Any use of trade, product, or firm names is for descriptive purposes only and does not imply endorsement by the U.S. Government.

Although this report is in the public domain, permission must be secured from the individual copyright owners to reproduce any copyrighted material contained within this report.

Cover: Southeast shore of White Lake, Bladen County, N.C. This lake, one of five natural lakes in the Elizabethtown 1:100,000 quadrangle, fills a Carolina bay that formed in dune sands of the Pinehurst Formation. Photograph by Robert E. Weems (U.S. Geological Survey). 


\section{Contents}

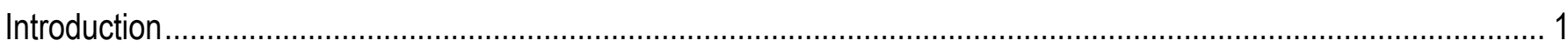

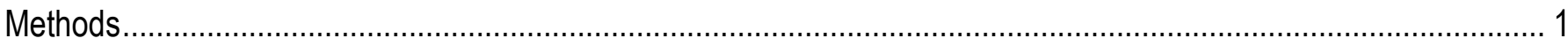

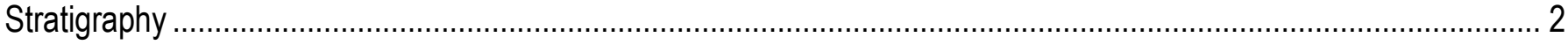

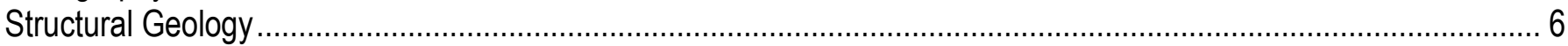

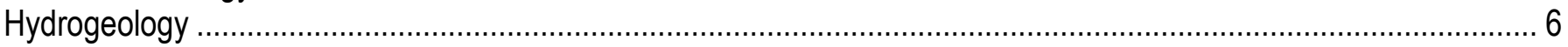

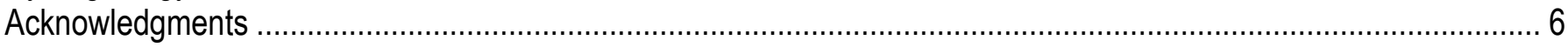

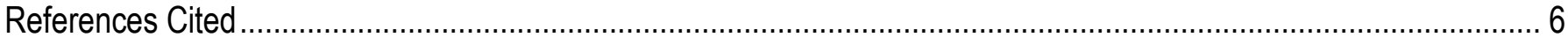

Appendix 1. Locality Descriptions and Detailed Lithologic Logs ..................................................................18

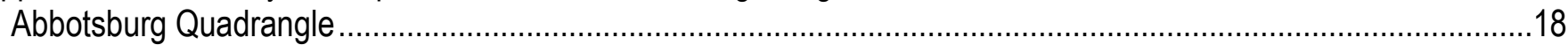

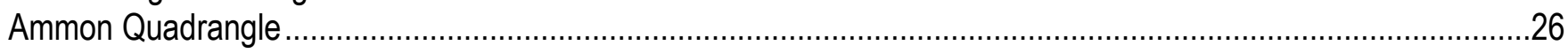

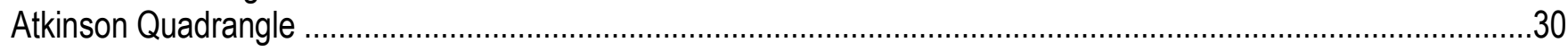

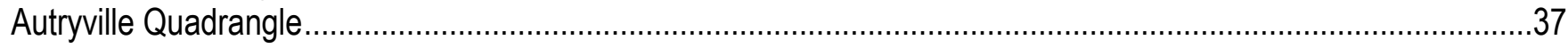

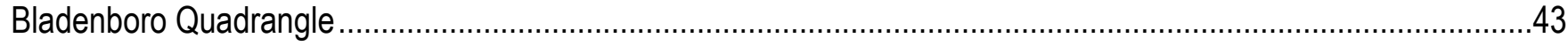

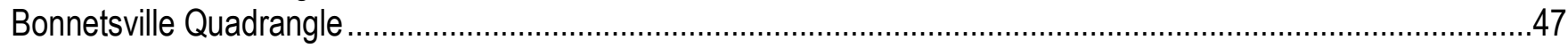

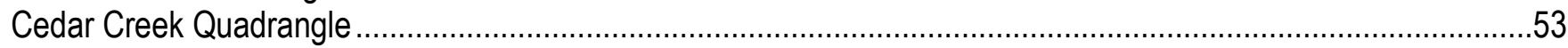

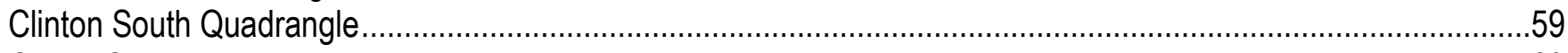

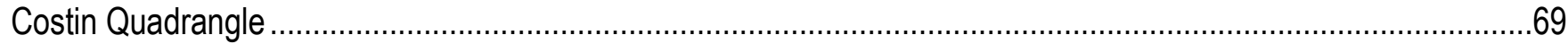

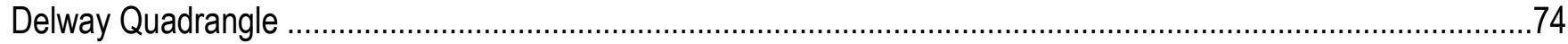

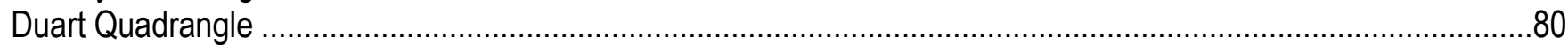

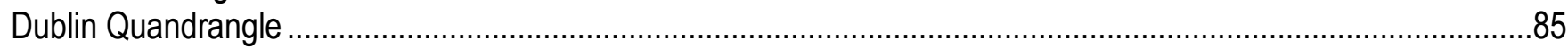

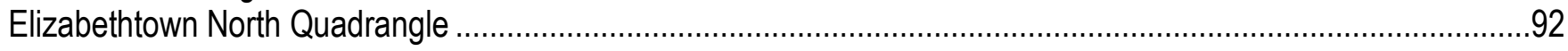

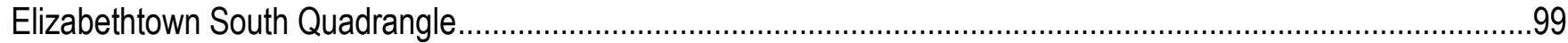

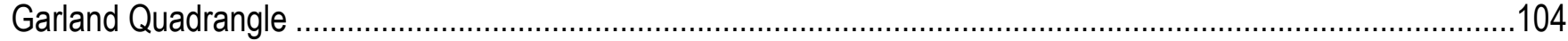

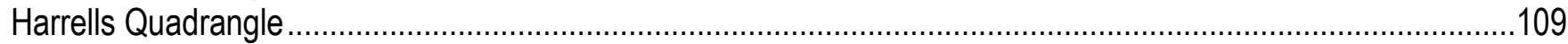

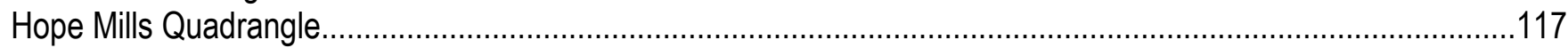

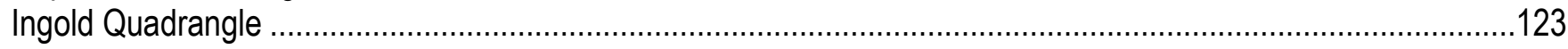

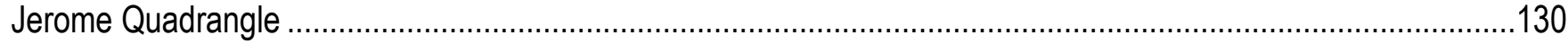

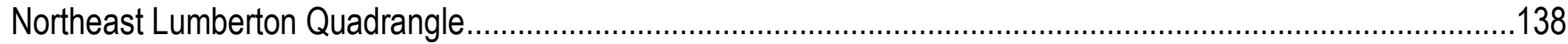

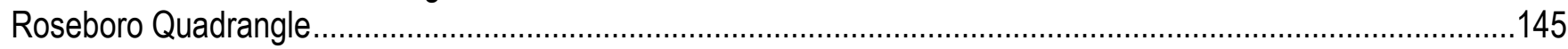

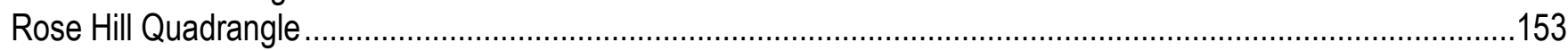

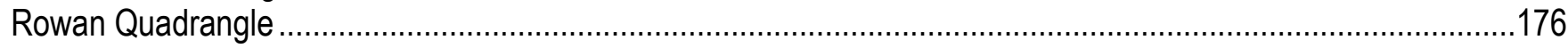

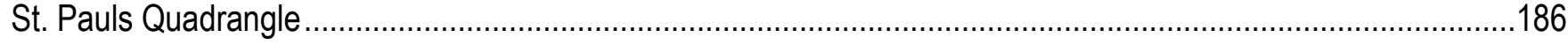

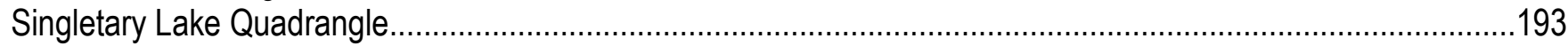

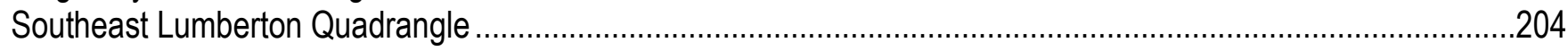

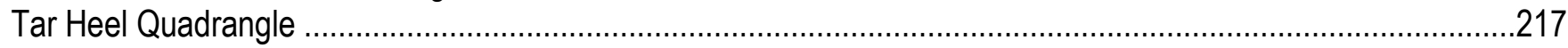

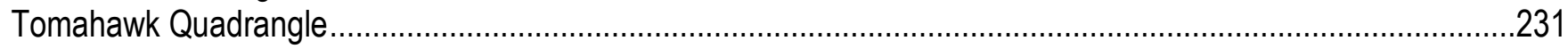

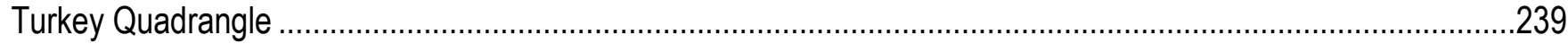

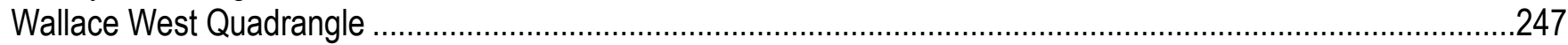

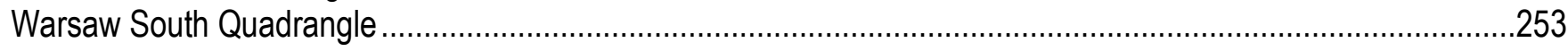

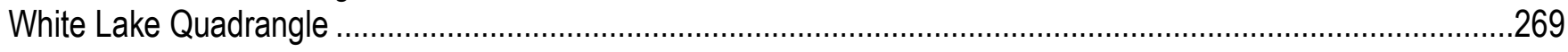

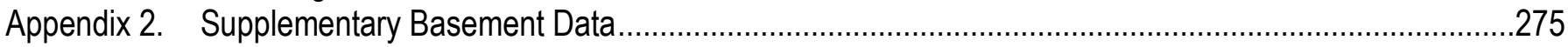

Appendix 3. Fossil Mollusk and Vertebrate Taxa Recovered in the Elizabethtown 1:100,000-Scale Quadrangle...277 Appendix 4. Upper Cretaceous Fossil Vertebrate Taxa Reported by Miller (1966, 1967, 1968), Baird and Horner (1979), and Robb (1989) From Phoebus Landing in the Elizabethtown 1:100,000-Scale Quadrangle .......................284 


\section{Figures}

1. Map of the Elizabethtown 1:100,000-scale quadrangle showing names and locations of constituent 1:24,000-scale topographic maps, county names and boundaries, and auger-hole locations......

2. Structure-contour map of the Elizabethtown 1:100,000-scale quadrangle showing the base of the

Coastal Plain ....

3. Generalized geologic map of the Elizabethtown 1:100,000-scale quadrangle showing faults and the subsurface distribution of Duplin Formation and older units beneath the Pliocene to Pleistocene terrace units.

4. Structure-contour map of the Elizabethtown 1:100,000-scale quadrangle showing the base of the

surficial aquifer .....

\section{Tables}

1. Age and sequence of stratigraphic units penetrated during augering..........

2. Nomenclature and maximum elevation for terrace units in map area 


\section{Conversion Factors}

\begin{tabular}{lcl}
\hline \multicolumn{1}{c}{ Multiply } & \multicolumn{1}{c}{ By } & \multicolumn{1}{c}{ To obtain } \\
\hline inch (in.) & Length & \\
inch (in.) & 2.54 & centimeter (cm) \\
foot (ft) & 25.4 & millimeter (mm) \\
mile (mi) & 0.3048 & meter (m) \\
mile, nautical (nmi) & 1.609 & kilometer (km) \\
yard (yd) & 1.852 & kilometer (km) \\
& 0.9144 & meter (m) \\
centimeter (cm) & & \\
millimeter (mm) & 0.3937 & inch (in.) \\
meter (m) & 0.03937 & inch (in.) \\
kilometer (km) & 3.281 & foot (ft) \\
kilometer (km) & 0.6214 & mile (mi) \\
meter (m) & 0.5400 & mile, nautical (nmi) \\
\hline
\end{tabular}





\section{Detailed Sections From Auger Holes in the Elizabethtown 1:100,000-Scale Quadrangle, North Carolina}

By Robert E. Weems, William C. Lewis, Joseph H. Murray, David B. Queen, Jeffrey B. Grey, and Benjamin D. DeJong

\section{Introduction}

The Elizabethtown 1:100,000 quadrangle is in the west-central part of the Coastal Plain of southeastern North Carolina (fig. 1). The Coastal Plain, in this region, consists mostly of unlithified sediments that range in age from Late Cretaceous to Holocene. These sediments lie with profound unconformity on complexly deformed metamorphic and igneous rocks similar to rocks found immediately to the west in the Piedmont province. Coastal Plain sediments generally dip gently to the southeast or south and reach a maximum thickness of about 850 feet $(\mathrm{ft})$ in the extreme southeast part of the map area (fig. 2). The gentle southerly and southeasterly dip is disrupted in several areas by faulting.

The U.S. Geological Survey (USGS) recovered one core and augered 196 research test holes in the Elizabethtown 1:100,000 quadrangle to supplement sparse outcrop data in the map area. The recovered sediments were studied and data from these sediments recorded to determine the lithologic characteristics, spatial distribution, and temporal framework of the represented Coastal Plain stratigraphic units. These test holes were critical for accurately determining the distribution of major geologic units and the position of unit boundaries on the Elizabethtown geologic map (Weems and others, 2011); however, because much of the detailed subsurface data cannot be shown readily by means of this quadrangle map, detailed descriptions (appendix 1) have been collected in this open-file report for geologists, hydrologists, engineers, and community planners to provide a detailed shallow-subsurface stratigraphic framework for the Elizabethtown map region.

\section{Methods}

Surface elevations for each drill site were obtained by hand leveling from a known elevation, commonly a bench mark or spot elevation point on the appropriate 7.5-minute quadrangle. Lithologic data were gathered at each test site by augering with a truck-mounted, Mobile Drill B-40 power auger equipped with 5-ft-long drill stem sections. First one stem was augered into the ground and pulled to describe the soil profile. Subsequent runs added one, two, or three new stems, depending on depth and the ease of augering. The sample rise on the drill stems was kept to a minimum for greater accuracy.

Auger holes generally targeted the upper few feet of the Upper Cretaceous Cape Fear or Tar Heel Formations, except in the far eastern map region where the Upper Cretaceous Bladen Formation, the Upper Cretaceous Donoho Creek Formation, or the middle Eocene Castle Hayne 
Limestone marked the deepest lithologic unit that could be readily reached with the B-40. Occasionally the drill bit would not penetrate an underlying lithified bed within the Coastal Plain section (here termed "refusal"). The nature of this rock unit sometimes could be inferred either by small chips on the end of the drill bit or by comparison to nearby outcrops or auger holes.

Lithologic descriptions were made by using a 10X hand lens, grain-size chart, and color charts. Auger sites were plotted on location with 7.5-minute topographic maps. Latitudes and longitudes were established either by using published USGS maps (North American Datum of 1927) or by using hand-held Garmin global positioning system (GPS) units.

\section{Stratigraphy}

A full listing of the stratigraphic names used here, their ages, and their general lithologic descriptions are given in table 1. Coastal Plain formational units are bounded by unconformities; formations generally start with a relatively coarse basal lag bed and fine upward. Members in formations, where present, generally represent distinctive lithologic facies that occur within that formation. Surficial stratigraphic units, bounding scarps, and overlying terrace surface names are summarized in table 2. Pre-Pliocene unit names mostly conform to those unit names used in this region by Owens (1989) and Sohl and Owens (1991). Names and definitions of Pliocene and Pleistocene terrace deposits largely follow the usages of Johnson and Berquist (1989) and Mixon and others (1989).

Older Coastal Plain units, mostly encountered in the shallow subsurface or along valley walls of deeply incised streams, include the Pleasant Creek Formation (Late Cretaceous, Coniacian and Santonian ages; documented in the map area only by Self-Trail, Wrege, and others (2004) from the deepest part of the Elizabethtown core), the updip and onshore lateral equivalent Cape Fear Formation (Late Cretaceous, Coniacian and Santonian ages), the Tar Heel Formation (Late Cretaceous, Campanian age), the Bladen Formation (Late Cretaceous, Campanian age), the Donoho Creek Formation (Late Cretaceous, Campanian age), the Castle Hayne Limestone (middle Eocene), and the Duplin Formation (late middle to late Pliocene). The subsurface distribution of these units is shown in figure 3.

The Cape Fear Formation was named for cross-bedded feldspathic sands that crop out in the northwestern map area along the lower Rockfish Creek. This unit appears to have been formed by anastomosing braided streams, which spread sand widely across the map area. In the eastern area, these deposits overlie and also seemingly intertongue with marine deposits of the age-equivalent Pleasant Creek Formation (Self-Trail, Prowell, and Christopher, 2004; Self-Trail, Wrege, and others, 2004).

The interbedded sands and clays of the overlying Tar Heel Formation, named for outcrops north of the community of Tar Heel along the Cape Fear River (Sohl and Owens, 1991), formed in marginal marine deltaic environments and contain abundant woody material, local diverse marine vertebrate faunas, and occasional remains of terrestrial vertebrates including dinosaurs (Miller, 1966, 1967, 1968; Baird and Horner, 1979; Robb, 1989; Self-Trail, Christopher, and others, 2004). Glauconitic sands in the Tar Heel Formation near Lumberton (auger holes SL-1-06 and SL-2-06) are probably the source of Late Cretaceous shark teeth reworked into the base of the Pliocene Duplin Formation in the Lumberton area (see appendix 3). These shark teeth attest to marine environments in the Lumberton area as early as the Campanian, and also attest to a steady westward expansion of the Coastal Plain marine depositional environment between the Santonian and Campanian ages. 
The Bladen Formation overlies the Tar Heel Formation and is widespread across the eastern and southeastern map region (fig. 3). The Bladen Formation is well exposed at Walkers Bluff (Farrell and others, 2001) and documents another marked westward shift in the Coastal Plain depositional environment beyond that represented by the Tar Heel Formation. All deposits preserved in this map area represent shallow to mid-shelf marine environments, and the landward equivalents have been long since eroded away. The overlying Donoho Creek Formation is very similar lithologically to the Bladen Formation, but the Donoho Creek is consistently somewhat darker (almost always dark-olive-gray (5Y 3/1)). The pattern of distribution (fig. 3) strongly suggests an interval of erosion and channeling between the time the Bladen was deposited and the time the Donoho Creek was deposited. The contact between the Bladen and the Donoho Creek was encountered in three auger holes (RH-6-04, RH-9-04, RH-12-04), where a distinct lag bed marks the contact.

The limited spatial distribution of the Castle Hayne Limestone in the northeastern map area (fig. 3) suggests that the preserved deposits occupy a deeply incised paleo-valley system. The fabric, lithology, and fauna of the Castle Hayne, however, clearly show that its preserved deposits accumulated in a shallow to mid-shelf depositional environment that was far from any significant source of detrital sediment. Therefore, the preserved deposits did not form in restricted, estuarine environments as their channel-like geometry might suggest. Either fluvial-estuarine deposits, if once present, were swept away by submarine erosion, or else these channels were entirely sculpted by submarine erosion. This unit must have been continuous over much or all of the map area when it was originally deposited and only later was removed from most of the area by regional erosion.

The Duplin Formation was named from a collapsed sinkhole feature called Natural Well in the northeastern map area (fig. 1, locality WS-6-04). This unit is a very shelly sand deposit that contains a planktonic foraminiferal assemblage characteristic of Zone PL3 (Dowsett and Wiggs, 1992; Gradstein and others, 2004); the age of the Duplin is likely between 3.1 and 3.6 million years old (mega-annum, or Ma) (latest Zanclean and (or) early Piacenzian). Recent strontium dating of shells from outcrops along the Lumber River in the southwestern map area, however, suggests that the age of the Duplin there may range from 2.8 to 2.2 Ma (Graybill and others, 2009), which is younger than previously assumed. The Duplin generally has been considered to be time-equivalent to the upper part of the Yorktown Formation in northern North Carolina and Virginia, and quite possibly is equivalent in age to the unit immediately overlying the Rushmere and Morgarts Beach Members in the Roanoke Rapids region, called “Ty3” by Weems and Lewis (2007). Like the Castle Hayne, the Duplin has a very patchy distribution (fig. 3) but must have been present across all or most of the map area. These patchy remnants indicate that the map area, astride a zone of relative uplift called the Cape Fear arch, has been intermittently upwarped throughout most of the Cenozoic Era; however, the presence of late Pliocene and Quaternary terrace deposits that are not perceptibly warped indicates that this uplift has not been active during the last 3 million years.

Most of the surficial stratigraphic units that lie above the Duplin contain very similar facies that formed in fluvial, backbarrier, and sometimes barrier, shoreface, and near-shore depositional environments. These various units, where not heavily eroded, all fine upward to terrace surfaces that have regionally distinctive ranges of elevation. Each of these terrace packages represents an interglacial high stand of sea level. Continuous growth of the East Antarctic ice sheet over the past 2.8 million years (Barrett and others, 1992; Wilson, 1995; Ingólfsson, 2004) has prevented each successive terrace sequence from reaching the same elevation that the sequence reached during the preceding transgression because of steady net lowering of the world ocean; therefore, successively younger terraces form a downward-descending, stairstep sequence of flat-topped terraces separated 
from each other by scarps that range from pronounced to subtle. Although each sequence is internally similar to the others, older terraces have progressively deeper and more pronounced weathering profiles and show progressively greater erosional degradation. Because each sequence becomes more nearly marine seaward (eastward), each unit shows an internal gradational shift southeastward toward finer lithologies, but shows an abrupt change from finer to coarser when moving from one terrace to the next younger one seaward. All of these criteria have been useful for distinguishing one terrace complex from another. Terrace, scarp, and formational usages are summarized in table 2 .

The oldest terrace unit exposed in the map area consists of poorly sorted, clayey sand that occurs beneath a terrace that tops regionally at elevations ranging from $230 \mathrm{ft}$ in the western part of its outcrop belt to $195 \mathrm{ft}$ in the eastern part of its outcrop belt. This unit was named the Coharie Formation by Stephenson (1912), but since then the name has been restricted to terrace nomenclature (Colquoun, 1969). In the southeastern part of the Emporia 1:100,000-scale quadrangle, a thick estuary fill underlies a portion of this terrace and links it southeastward with sediments in the Chowan River area (Weems and others, 2010); therefore, the Coharie terrace unit appears to represent coastal and onshore strata that are age equivalent to the lower Pleistocene (Gelasian) Edenhouse Member of the Chowan River Formation (Blackwelder, 1981; Gibbard and others, 2010). This unit is most widespread in the far northwestern map area, but outliers also have been recognized and mapped in the central and northeastern area.

Terrace deposits between the elevations of 185 and $105 \mathrm{ft}$ previously have been lumped together to the north in Virginia as the Bacons Castle Formation; however, two distinct units are represented in this complex, separated by a scarp at 137 to $147 \mathrm{ft}$. This scarp has been called the "Parler scarp" in South Carolina (Colquhoun, 1965) and the "Mechanicsville scarp" in northern South Carolina and southern North Carolina (DuBar and others, 1974). The name "Parler scarp" is used in this report. The older terrace deposit above the Parler scarp is designated as the "Varina Grove unit," after the Varina Grove Member of the Bacons Castle Formation as used by Johnson, Goodwin, and others (1987). The relative position of the Varina Grove unit in the regional stratigraphic system suggests that this unit may be the updip and nearshore to onshore equivalent of the Colerain Beach Member of the Chowan River Formation (Blackwelder, 1981).

The younger parts of what has been called the Bacons Castle Formation in Virginia are here assigned to the Waccamaw Formation and designated as the "Bahramsville unit" and the "Moorings unit" after the Bahramsville Member and the Moorings Member of the Bacons Castle Formation as used by Johnson, Goodwin, and others (1987) and Johnson, Ward and Peebles (1987). At Walkers Bluff in the southern part of the map southeast of Elizabethtown on the Cape Fear River, a shallow-shelf marine deposit is present that has been biostratigraphically dated as early Pleistocene (Newton and others, 1978; Graybill and others, 2009). This marine unit yields strontium ages (W. Burleigh Harris, University of North Carolina-Wilmington, oral commun., 2009; Badyrka and others, 2010) that are virtually identical to those ages from the type area of the Waccamaw Formation along the Waccamaw River (Dall, 1892; Blackwelder and Ward, 1979); therefore, this unit is assigned to the Waccamaw along with the conformably overlying Bahramsville and Moorings units. To avoid confusion, the shelly marine facies of the Waccamaw is here called the James City Member, after the James City Formation of DuBar and Solliday (1963), which is age equivalent to the marine beds of the Waccamaw Formation (Blackwelder, 1981). The marine beds have been traced in auger holes westward as far as Abbottsburg and Dublin, almost to the toe of the westernmost barrier ridge of the Moorings unit. Local rapid infilling of the coastal region during the Waccamaw transgression probably allowed successive barrier ridges to form 
seaward of each other, burying these shallow-shelf marine sediments beneath successive, slightly younger and more seaward barriers. In other areas where multiple barrier ridges did not develop, age-equivalent shallow-shelf deposits were not preserved.

Similar lagoonal deposits closer to shore are associated with the next younger Windsor Formation near Rose Hill and Costin. These deposits are somewhat younger than the Waccamaw Formation but still early Pleistocene in age. In the past, the shelly parts of the Windsor often have been lumped together with the Waccamaw Formation. All younger Pleistocene units in the map area (the Charles City, Chuckatuck, Shirley, and Tabb Formations) represent nonmarine (fluvial to estuarine) marsh depositional environments. Their estuarine to marine facies are found only to the east and south of the map area.

Extensive sheets of dune sand (referred to the Pinehurst Formation in Weems and others, 2011) are present across all but the southeastern part of the map area and have been mapped as a separate unit distinct from the terrace deposits. Many have weak or no soil profile development and locally are often called "sugar sands" because they have only incipient soil profiles developed on them. Local deposits of this sort occur over a wide area in the Carolina and Georgia Coastal Plains (Markewich and Markewich, 1994) but are exceptionally thick and widespread in the Elizabethtown region. Two optically stimulated luminescence (OSL) ages from these dune sands in the map region indicate that they range in age at least from 8,575 $\pm 1,420$ to 13,000 \pm 930 years before present (B.P.) (one standard deviation (s.d.)) (Shannon A. Mahan, U.S. Geological Survey, written commun., 2005 and 2006, concerning localities HA-6-04 and AU-5-05, respectively). Radiocarbon ages from wood and peat samples taken from within these dune sand deposits in the map area yield ages ranging from 2,050 40 to greater than 51,800 yrs B.P. (John P. McGeehin, U.S. Geological Survey, written commun., 2005, 2007, and 2008, concerning localities CC-1-07, CS-7-08, ES-4-08, HA-5-04, NL-2-06, SL-4-07, SL-6-07, and TO-3-08). These dates are consistent with other studies that indicate these dune fields and associated Carolina bays mostly formed during the Wisconsin glacial interval (Frey, 1953, 1955; Whitehead, 1964; Markewich and Markewich, 1994; Ivester and others, 2004, 2007), though the sands locally were reactivated in Holocene time. These deposits are closely associated with the "Carolina bays” (Johnson, 1942; Kaczorowski, 1977) that are prominent in this region, and the alignment of the dunes generally matches the long axis of the bays. Indeed, although some bays seem to represent wind-created deflation features, many seem to have resulted from ellipsoidal dune development that built up the bay rims above the terrace surfaces on which they rest. Where bays sit directly on older terrace surfaces that have thick, clay-rich weathering profiles, the underlying clayey soils block downward water percolation and tend to allow the bays to become swamps or lakes. Where bays resulted from wind-driven excavation and deflation, and the underlying materials consist of fairly fresh and unweathered sands, bays tend to be well drained through subsurface flow and do not contain swamps or lakes. The dune fields and bays appear to have formed through the action of persistent strong winds that blew from northwest to southeast during the Wisconsin glacial interval. These winds paralleled the edge of the great ice sheet that then covered northern North America and thus are probably eastward extensions of the wind patterns that formed the extensive wind-blown loess deposits of the central United States and the Sand Hills of Nebraska (Zanner and Kuzila, 2001).

In the Cape Fear River valley, alluvium occurs beneath two distinctly different terrace surfaces that have been mapped separately. A similar stratigraphy has been documented in the Roanoke River Valley (Weems and Lewis, 2007), and a sample from the basal sands beneath the higher (older) terrace deposit in the Roanoke River valley yielded a quartz blue-light OSL age of $17,200 \pm 780$ years B.P. (one s.d.). This age indicates that this unit in the Roanoke River valley is 
no older than late Wisconsinan. The comparable terrace along the Cape Fear River also appears to represent a late Wisconsinan braided-river regime of the Cape Fear River that preceded a later postWisconsinan meandering-river regime (Leigh and others, 2004).

\section{Structural Geology}

Four faults (fig. 2) have been recognized in the Elizabethtown map area from anomalies in the Coastal Plain basement structure-contour map. These faults are the Clinton fault, the South River fault, the Turnbull fault, and the Cape Fear fault. A fifth structural feature, which marks the toe of a line of stream-gradient anomalies across the map area, appears to be a south-trending subsurface extension of the Tidewater Fall Line of Weems (1998). The Turnbull fault seems to deflect the course of the Cape Fear River to the south and also aligns with a remarkably straight region along Turnbull Creek. The South River also is remarkably linear along the trace of South River fault, and the zone of gradient anomalies has an obvious effect on most of the major stream gradients that cross the fault. No obvious surficial expression of the Clinton fault or the Cape Fear fault was observed within the map area.

\section{Hydrogeology}

In the map region, the surficial aquifer generally lies at the base of the surficial terrace unit. The surficial aquifer is the main stream recharge unit throughout the map area, and this aquifer is quite vulnerable to the introduction of surface pollutants. The geometry of the base of this aquifer is shown in figure 4. Deeper wells in the area generally tap aquifer horizons in the Cape Fear or Tar Heel Formations. These aquifers also are frequently tapped to the southeast as far as Wilmington, N.C., and overdrawing water from these aquifers could result in saltwater intrusion in the coastal regions to the southeast.

\section{Acknowledgments}

The authors would like to thank Lucy E. Edwards and Jean M. Self-Trail of the USGS for their thorough review of this manuscript. We also are grateful to Jean M. Self-Trail (USGS) for her numerous nannofossil identifications, which greatly helped in sorting out the very similar facies of the Bladen Formation, Donoho Creek Formation, and Castle Hayne Limestone in the eastern map area, and to Lucy E. Edwards for making dinoflagellate identifications from auger hole TH-1-06 that greatly helped in constraining the age of the basal unit in that hole. Finally, we thank Shannon A. Mahan (USGS) and John P. McGeehin (USGS) for providing very helpful OSL and carbon-14 dates on samples from various late Pleistocene units in the map area.

\section{References Cited}

Badyrka, K.A., Kelley, P.H., Harris, W.B., Dietl, G.P., and Visaggi, C.C., 2010, Paleontologic and strontium isotopic age analysis of the Waccamaw Formation, Waccamaw River and Intracoastal Waterway, Horry County, South Carolina [abs.]: Geological Society of America Abstracts with Programs, v. 42, no. 1, p. 187.

Baird, D., and Horner, J.R., 1979, Cretaceous dinosaurs of North Carolina: Brimleyana, v. 2, p. 128. 
Barrett, P.J., Adams, C.J., McIntosh, W.C., Swisher, C.C., and Wilson, G.S., 1992,

Geochronological evidence supporting Antarctic deglaciation three million years ago: Nature, $\mathrm{v}$. 359, p. 816-818.

Blackwelder, B.W., 1981, Stratigraphy of upper Pliocene and lower Pleistocene marine and estuarine deposits of northeastern North Carolina and southeastern Virginia; Contributions to stratigraphy: U.S. Geological Survey Bulletin, 1502-B, 16 p., 1 pl.

Blackwelder, B.W., and Ward, L.W., 1979, Stratigraphic revision of the Pliocene deposits of North and South Carolina: South Carolina Division of Geology, Geologic Notes, v. 23, no. 1, p. 33-43. Campbell, L.D., 1993, Pliocene molluscs from the Yorktown and Chowan River formations in Virginia: Virginia Division of Mineral Resources Publication 127, 259 p., 43 pls.

Colquhoun, D.J., 1965, Terrace sediment complexes in central South Carolina, Atlantic Coastal Plain Geological Association field conference 1965 Guidebook, Sixth Annual Field Conference Guidebook, Columbia, S.C.: Columbia S.C., University of South Carolina, 62 p.

Colquhoun, D.J., 1969, Geomorphology of the lower Coastal Plain of South Carolina: State Development Board, Division of Geology, Publication MS-15, 36 p., 1 pl.

Dall, W.H., 1892, Contributions to the Tertiary fauna of Florida, with special reference to the Miocene Silex beds of Tampa and the Pliocene beds of the Caloosahatchie River: Wagner Free Institute of Science Transactions, v. 3, pt. 2, 1654 p.

Dowsett, H.J., and Wiggs, L.B., 1992, Planktonic foraminiferal assemblage of the Yorktown Formation, Virginia, USA: Micropaleontology, v. 38, no. 1, p. 75-86.

DuBar, J.R., Johnson, H.S., Jr., Thom, B., and Hatchell, W.O., 1974, Neogene stratigraphy and morphology, south flank of the Cape Fear Arch, North and South Carolina, in Oaks, R.Q., Jr., and DuBar, J.R., eds., Post-Miocene stratigraphy; Central and southern Atlantic Coastal Plain: Logan, Utah, Utah State University Press, p. 139-173.

DuBar, J.R., and Solliday, J.R., 1963, Stratigraphy of the Neogene deposits, lower Neuse estuary, North Carolina: Southeastern Geology, v. 4, no. 4, p. 213-233.

Farrell, K.M., Ward, L.W., Heron, S.D., Jr., 2001, Cape Fear River transect-The Upper Cretaceous Cape Fear, Black Creek and Peedee Formations of southeastern North Carolina and overlying Cenozoic section (milepost 111 to milepost 25), field trip guidebook (April, 2001): Geological Society of America, Southeastern Section, v. 50, p. 93-118.

Frey, D.G., 1953, Regional aspects of the late-glacial and post-glacial pollen succession of southeastern North Carolina: Ecological Monographs, v. 23, no. 3, p. 289-313.

Frey, D.G., 1955, A time revision of the Pleistocene pollen chronology of southeastern North Carolina: Ecology, v. 36, no. 4, p. 762-763.

Gibbard, P.L., Head, M.J., Walker, M.J.C., and the Subcommission on Quaternary Stratigraphy, 2010, Formal ratification of the Quaternary System/Period and the Pleistocene Series/Epoch with a base at 2.58 Ma: Journal of Quaternary Science, v. 25, p. 96-102.

Gradstein, F.M., Ogg, J.G., Smith, A.G., and others, 2004, A geologic time scale 2004: Cambridge, United Kingdom, Cambridge University Press, 610 p.

Graybill, E.A., Harris, W.B., Kelley, Patricia, Dietl, Gregory, and Visaggi, C.C., 2009, Age of the Duplin and Waccamaw Formations, Cape Fear River basin, North Carolina [abs.]: Geological Society of America Abstracts with Programs, v. 41, no. 1, p. 45.

Ingólfsson, Ólafur, 2004, Quaternary glacial and climate history of Antarctica, in Ehlers, J., and Gibbard, P.L., eds., Quaternary glaciations-Extent and chronology, part III; South America, Asia, Australia, Antarctica: Amsterdam, Elsevier, p. 3-43. 
Ivester, A.H., Brooks, M.J., and Taylor, B.E., 2007, Sedimentology and ages of Carolina bay sand rims [abs.]: Geological Society of America Abstracts with Programs, v. 39, no. 2, p. 5.

Ivester, A.H., Godfrey-Smith, D.I., Brooks, M.J., and Taylor, B.E., 2004, Chronology of Carolina bay sand rims and inland dunes on the Atlantic Coastal Plain, USA; The Third New World Luminescence Dating Workshop, Department of Earth Science, Dalhousie University, Halifax, Nova Scotia, July 4-7, 2004: Halifax, Nova Scotia, Canada, Dalhousie University, p. 23.

Johnson, D.W., 1942, The origin of the Carolina Bays: New York, Columbia University Press, 341

p.

Johnson, G.H., and Berquist, C.R., 1989, Geology and mineral resources of the Brandon and Norge quadrangles, Virginia: Virginia Division of Mineral Resources Publication 87, 28 p.

Johnson, G.H., Goodwin, B.K., Ward, L.W., and Ramsey, K.W., 1987, Tertiary and Quaternary stratigraphy across the Fall Zone and western Coastal Plain, southern Virginia, Trip 3 in Whittecar, G.R., ed., Geological excursions in Virginia and North Carolina-Geological Society of America, Southeast Section, 36th Annual Meeting, 1987, Guidebook: Norfolk, Va., Old Dominion University, p. 87-144.

Johnson, G.H., Ward, L.W., and Peebles, P.C., 1987, Stratigraphy and paleontology of Pliocene and Pleistocene deposits of southeastern Virginia, in Whittecar, G.R., ed., Geological excursions in Virginia and North Carolina-Geological Society of America, Southeast Section, 36th Annual Meeting, 1987, Guidebook: Norfolk, Va., Old Dominion University, p. 189-218.

Kaczorowski, R.T., 1977, The Carolina bays-A comparison with modern oriented lakes: University of South Carolina, Coastal Research Division, Technical Report Number 13, 124 p.

Lawrence, D.P., and Hoffman, C.H., 1993, Geology of basement rocks beneath the North Carolina Coastal Plain: North Carolina Geological Survey Bulletin 95, 60 p., map, scale 1:500,000.

Leigh, D.S., Srivastrava, Pradeep, and Brook, G.A., 2004, Late Pleistocene braided rivers of the Atlantic Coastal Plain, USA: Quaternary Science Reviews, v. 23, p. 65-84.

Markewich, H.W., and Markewich, William, 1994, An overview of Pleistocene and Holocene inland dunes in Georgia and the Carolinas-Morphology, distribution, age, and paleoclimate: U.S. Geological Survey Bulletin 2069, 32 p.

Miller, H.W., 1966, Cretaceous vertebrate fauna from Phoebus Landing, North Carolina [abs.]: Journal of the Elisha Mitchell Scientific Society, v. 82, no. 2, p. 93.

Miller, H.W., 1967, Cretaceous vertebrates from Phoebus Landing, North Carolina: Proceedings of the Academy of Natural Sciences of Philadelphia, v. 119, p. 219-239.

Miller, H.W., 1968, Additions to the Upper Cretaceous vertebrate fauna of Phoebus Landing, North Carolina: Journal of the Elisha Mitchell Scientific Society, v. 84, no. 4, p. 467-471.

Mixon, R.B., Berquist, C.R., Jr., Newell, W.L., Johnson, G.H., Powars, D.S., Schindler, J.S., and Rader, E.K., 1989, Geologic map and generalized cross sections of the Coastal Plain and adjacent parts of the Piedmont, Virginia with generalized geologic cross sections: U.S. Geological Survey Miscellaneous Investigations Map I-2033, scale 1:250,000.

Newton, C.R., Belknap, D.F., and Lynts, G.W., 1978, Early Pleistocene (Calabrian) age of the Waccamaw Formation at Walker's Bluff, Elizabethtown, N.C.[abs.]: Geological Society of America Abstracts with Programs, v. 10, no. 4, p. 194.

North Carolina Geological Survey, 2010, Ground water databases: Raleigh, N.C., North Carolina Geological Survey database accessed February 4, 2011 at http://www.ncwater.org/Data_and_Modeling/Ground_Water_Databases/.

Owens, J.P., 1989, Geologic map of the Cape Fear region, Florence $1^{\circ} \times 2^{\circ}$ quadrangle and northern half of the Georgetown $1^{\circ} \times 2^{\circ}$ quadrangle, North Carolina and South Carolina: U.S. 
Geological Survey Miscellaneous Investigations Series Map, I-1948-A, 2 sheets, scale 1:250,000.

Robb, A.J., III, 1989, The Upper Cretaceous (Campanian, Black Creek Formation) fossil fish fauna of Phoebus Landing, Bladen County, North Carolina: The Mosasaur, v. 4, p. 75-92.

Self-Trail, J.M., Christopher, R.A., Prowell, D.C., and Weems, R.E., 2004, The age of dinosaurbearing strata at Phoebus Landing, Cape Fear River, North Carolina [abs.]: Geological Society of America Abstracts with Programs, v. 36, no. 2, p. 117.

Self-Trail, J.M., Prowell, D.C., and Christopher, R.A., 2004, The Collins Creek and Pleasant Creek Formations-Two new Upper Cretaceous subsurface units in the Carolina/Georgia Coastal Plain: Southeastern Geology, v. 42, no. 4, p. 237-252.

Self-Trail, J.M., Wrege, B.M., Prowell, D.C., Seefelt, E.L., and Weems, R.E., 2004, Preliminary physical stratigraphy and geophysical data of the USGS Elizabethtown core (BL-244/BL-C-12003), Bladen County, North Carolina: U.S. Geological Survey Open-File Report 2004-1301, CD-ROM, scale 1:500,000.

Sohl, N.F., and Owens, J.P., 1991, Cretaceous stratigraphy of the Carolina Coastal Plain, in Horton, J.W., Jr., and Zullo, V.A., eds, The geology of the Carolinas, Carolina Geological Society fiftieth anniversary volume: Knoxville, Tenn., University of Tennessee Press, p. 191-220.

Stephenson, L.W., 1912, The Cretaceous, Lafayette, and Quaternary formations, in The coastal plain of North Carolina; Part 1, The physiography and geology of the coastal plain of North Carolina: North Carolina Geological and Economic Survey [Report], v. 3, p. 73-171, 258-290.

Trapp, Henry, Jr., 1992, Hydrogeologic framework of the northern Atlantic Coastal Plain in parts of North Carolina, Virginia, Maryland, Delaware, New Jersey, and New York: U.S. Geological Survey Professional Paper 1404-G, p. G1-G59.

Weems, R.E., 1998, Newly recognized en echelon fall lines in the Piedmont and Blue Ridge provinces of North Carolina and Virginia, with a discussion of their possible ages and origins: U.S. Geological Survey Open-File Report 98-374, 28 p.

Weems, R.E., and Lewis, W.C., 2007, Detailed sections from auger holes in the Roanoke Rapids 1:100,000 map sheet, North Carolina: U.S. Geological Survey Open-File Report 2007-1092, 220 p., scale 1:100,000.

Weems, R.E., Lewis, W.C., and Crider, E.A., 2011, Surficial geologic map of the Elizabethtown $30^{\prime} \times 60^{\prime}$ quadrangle, North Carolina: U.S. Geological Survey Open-File Report 2011-1121, 1 sheet, scale 1:100,000, available only online at http://pubs.usgs.gov/of/2011/1121/.

Weems, R.E., Schindler, J.S., and Lewis, W.C., 2010, Detailed sections from auger holes in the Emporia 1:100,000-scale quadrangle, North Carolina and Virginia: U.S. Geological Survey Open-File Report 2010-1121, 288 p.

Whitehead, D.R., 1964, Fossil pine pollen and full-glacial vegetation in southeastern North Carolina: Ecology, v. 45, no. 4, p. 767-777.

Wilson, G.S., 1995, The Neogene east Antarctic ice sheet-A dynamic or stable feature: Quaternary Science Reviews, v. 14, no. 2, p. 101-123.

Zanner, C.W., and Kuzila, M.S., 2001, Nebraska’s Carolina bays [abs.]: Geological Society of America Abstracts with Programs, v. 33, no. 6, p. 438. 



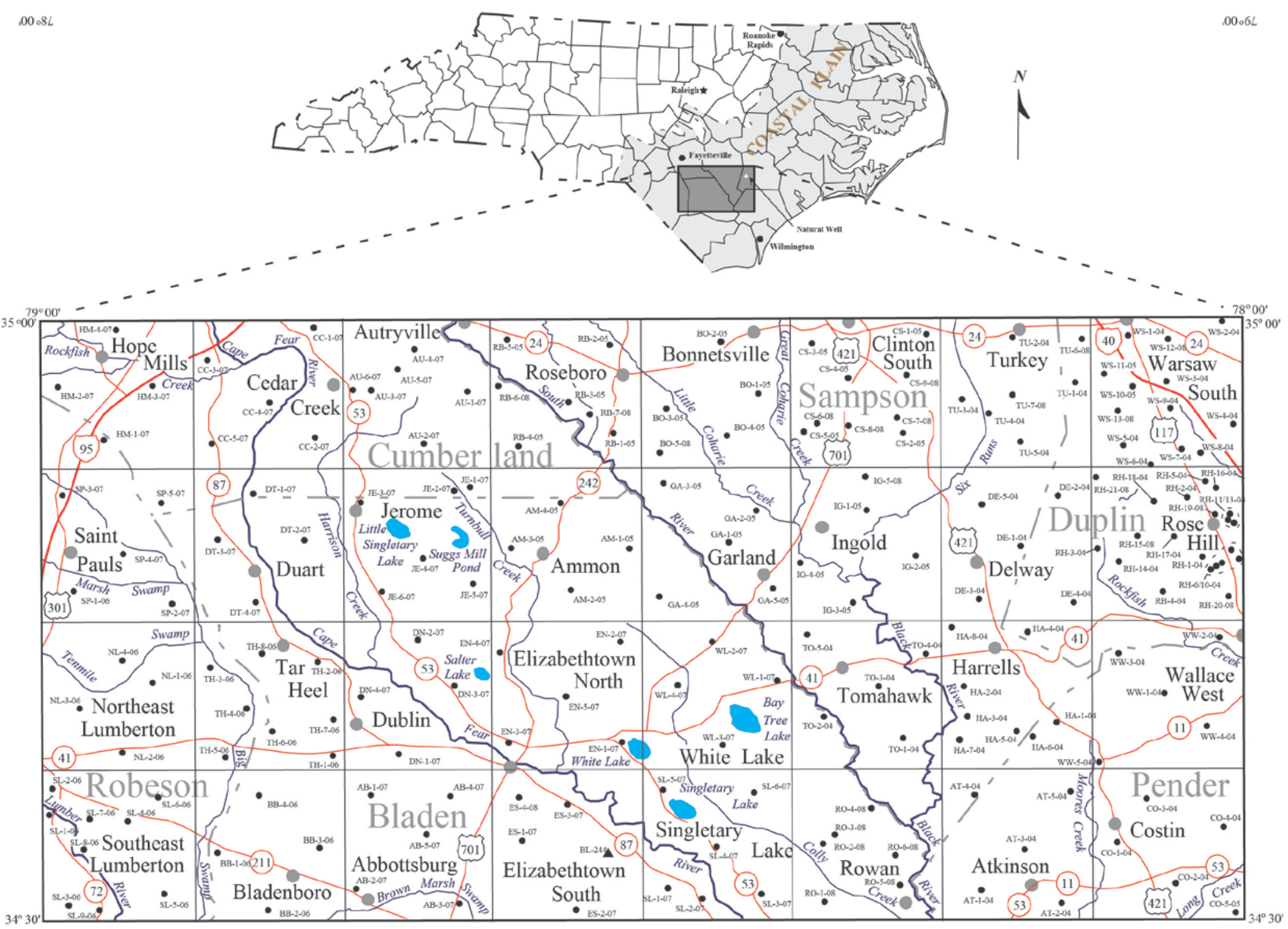

Figure 1. Map of the Elizabethtown 1:100,000-scale quadrangle showing names and locations of constituent 1:24,000-scale topographic maps, county names and boundaries, and auger-hole locations (small black circles). Base from U.S. Geological Survey State Map Index, 2001. 


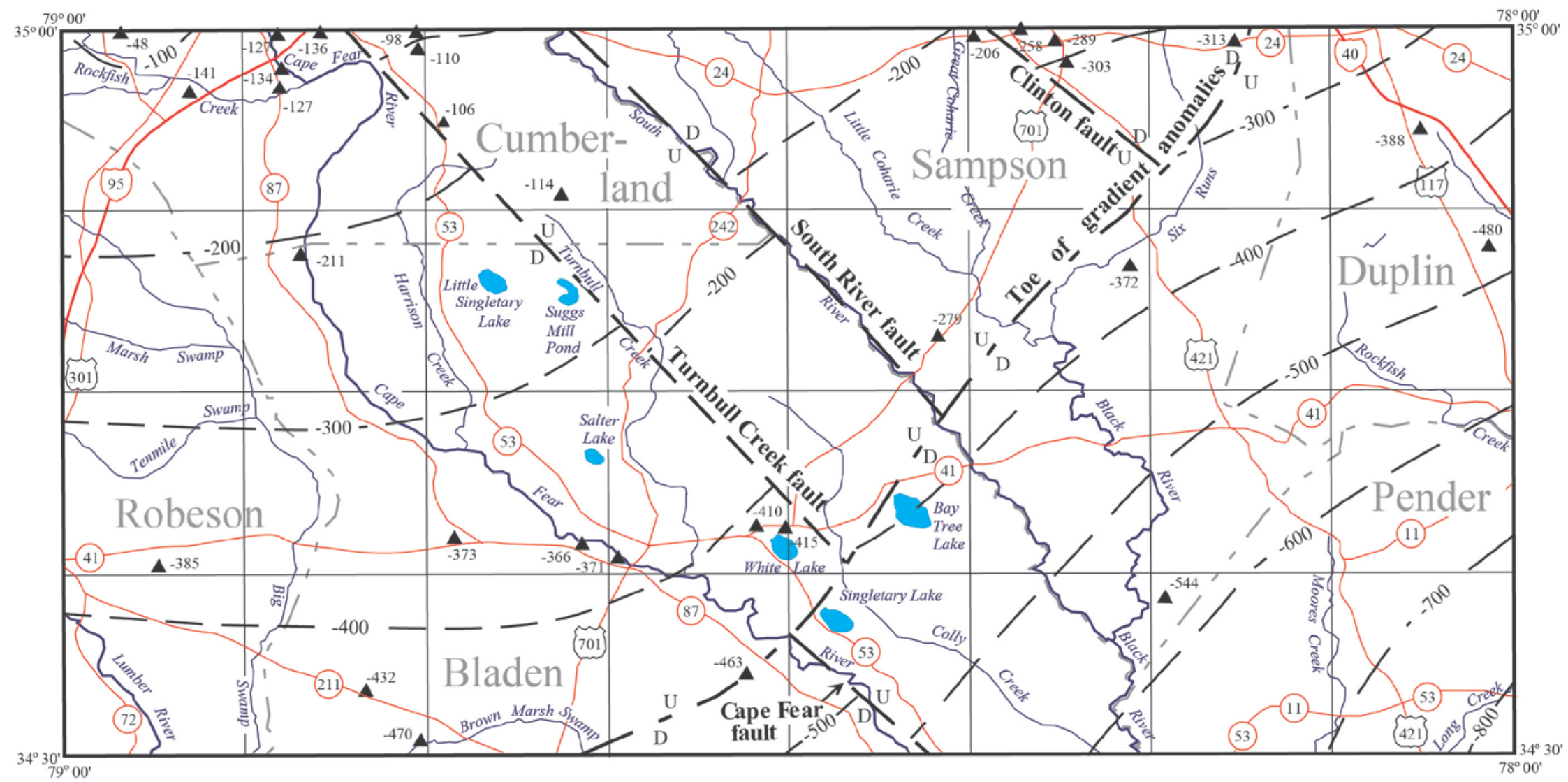

Figure 2. Structure-contour map of the Elizabethtown 1:100,000-scale quadrangle showing the base of the Coastal Plain. Structure contours (short-dashed lines) are in feet below sea level. Faults shown by long-dashed bold lines; U, upthrown block; D, downthrown block. Basement control points are shown by black triangles; values shown are in feet below sea level. The toe of gradient anomalies line (shown by the bold long- and shortdashed line) indicates the downstream end of a series of steepened stream gradients that are interpreted to mark the trace of a reactivated basement fault that moved up on its western side recently enough to prevent the intersected stream gradients from re-equilibrating. Base from U.S. Geological Survey State Map Index, 2001. 


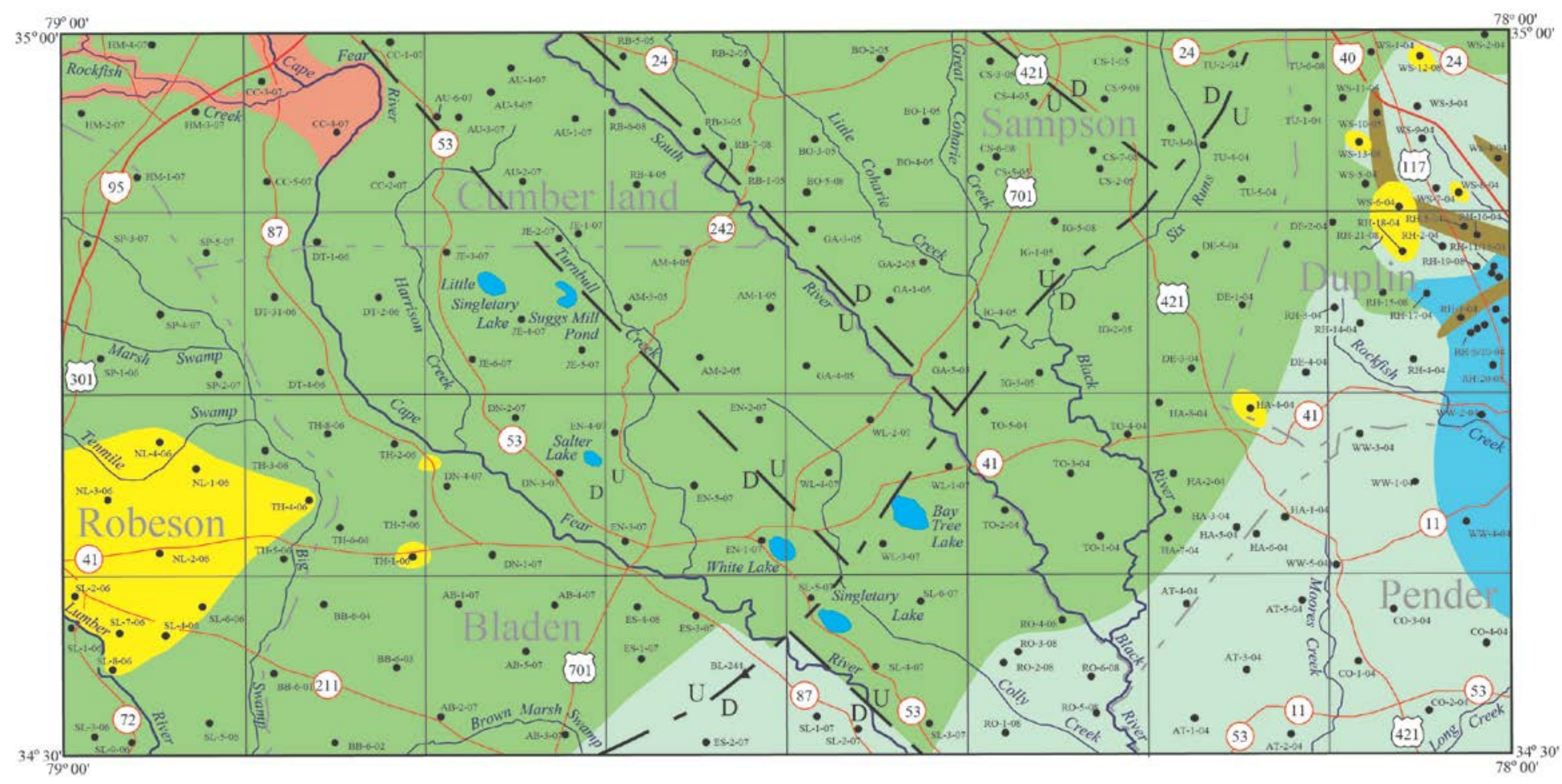

EXPLANATION

Cape Fear Formation

Upper Cretaceous,

Coniacian-Santonian)

Tar Heel Formation

(Upper Cretaceous, Campanian)
Bladen Formation

(Upper Cretaceous, Campanian)

Donoho Creek Formation

(Upper Cretaceous, Campanian
Castle Hayne Formation

(Eocene)

Duplin Formation (Pliocene)

- Location of subsurface control point (see "Locality Descriptions and Detailed Lithologic Logs.")

Figure 3. Generalized geologic map of the Elizabethtown 1:100,000-scale quadrangle showing faults and the subsurface distribution of Duplin Formation and older units beneath the Pliocene to Pleistocene terrace units. Subsurface control points (black circles) are described in "Locality Descriptions and Detailed Lithologic Logs." Base from U.S. Geological Survey State Map Index, 2001. 


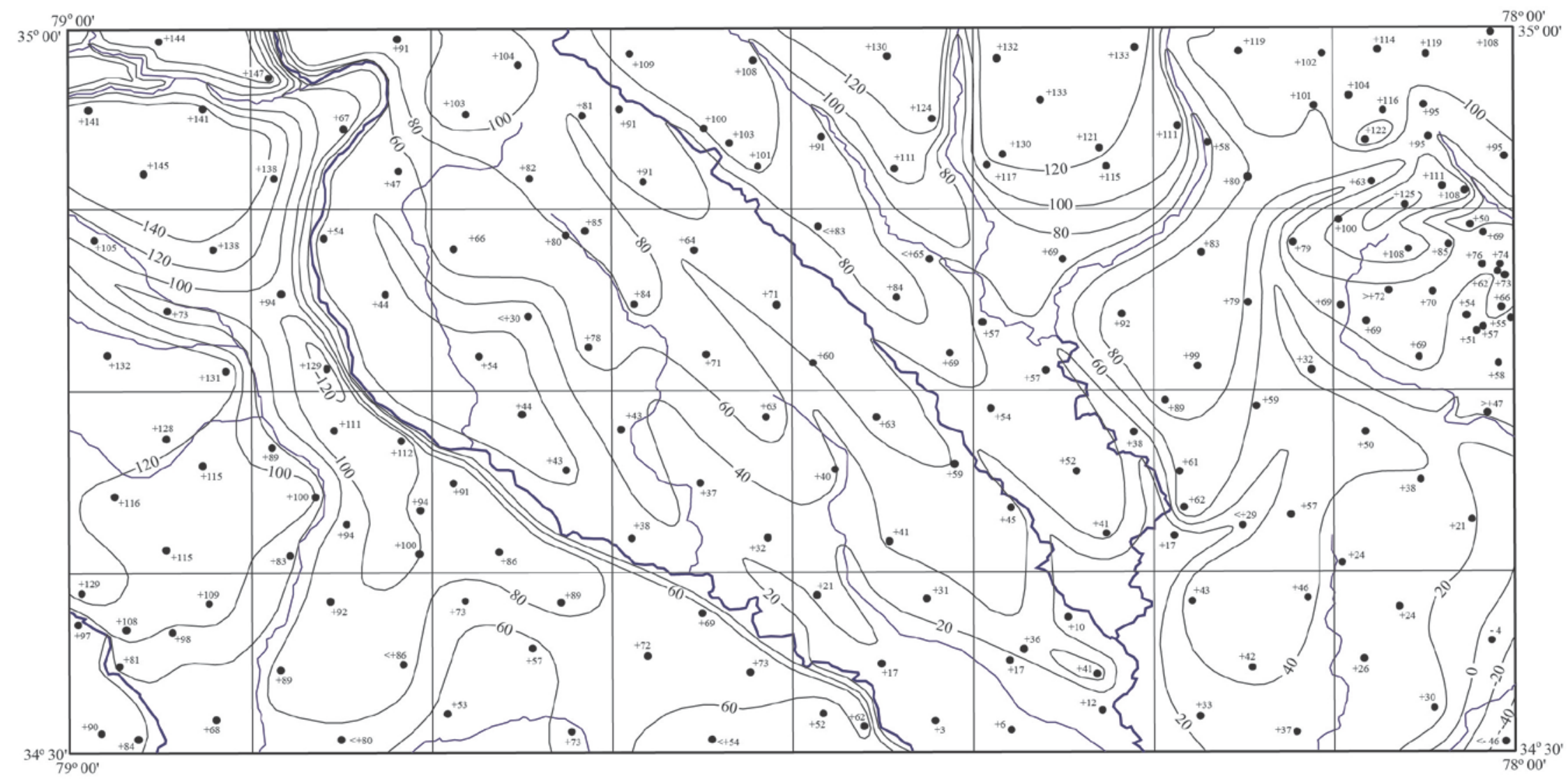

Figure 4. Structure-contour map of the Elizabethtown 1:100,000-scale quadrangle showing the base of the surficial aquifer. Subsurface control points are shown by black circles; values shown are elevations (in feet) above or below sea level. Base from U.S. Geological Survey State Map Index, 2001. 
Table 1. Age and relative position of stratigraphic units in map area.

\begin{tabular}{|c|c|c|}
\hline Unit & Lithology & Age \\
\hline Artificial fill & Materials variable & Holocene. \\
\hline Peaty marsh deposits & Peat and muck & Holocene and Pleistocene(?). \\
\hline Alluvium & $\begin{array}{l}\text { Fine to coarse quartz sand, silty or clayey, } \\
\text { pebbly }\end{array}$ & Holocene and Pleistocene(?). \\
\hline Older alluvium & $\begin{array}{l}\text { Fine to coarse quartz sand, silty or clayey, } \\
\text { gravelly }\end{array}$ & Holocene(?) and Pleistocene. \\
\hline Dune sand & $\begin{array}{l}\text { Fine to medium quartz sand, well-sorted, } \\
\text { clean }\end{array}$ & Holocene(?) and Pleistocene. \\
\hline Tabb Formation ${ }^{1}$ & $\begin{array}{l}\text { Fine to coarse quartz sand, poorly sorted, } \\
\text { clayey }\end{array}$ & Pleistocene. \\
\hline Shirley Formation & $\begin{array}{l}\text { Fine to coarse quartz sand, poorly sorted, } \\
\text { clayey }\end{array}$ & Pleistocene. \\
\hline Chuckatuck Formation & $\begin{array}{l}\text { Fine to coarse quartz sand, poorly sorted, } \\
\text { clayey }\end{array}$ & Pleistocene. \\
\hline Charles City Formation & $\begin{array}{l}\text { Fine to coarse quartz sand, poorly sorted, } \\
\text { clayey }\end{array}$ & Pleistocene. \\
\hline Windsor Formation & $\begin{array}{l}\text { Fine to coarse quartz sand, poorly sorted, } \\
\text { locally gravelly }\end{array}$ & Pleistocene. \\
\hline $\begin{array}{l}\text { Waccamaw Formation, } \\
\text { Moorings unit }\end{array}$ & Fine to medium quartz sand, well-sorted & Pleistocene. \\
\hline $\begin{array}{l}\text { Waccamaw Formation, } \\
\text { Bahramsville unit }\end{array}$ & $\begin{array}{l}\text { Fine to coarse quartz sand, poorly sorted, } \\
\text { muddy, gravelly }\end{array}$ & Pleistocene. \\
\hline $\begin{array}{l}\text { Waccamaw Formation, } \\
\text { James City Member }\end{array}$ & $\begin{array}{l}\text { Fine to coarse quartz sand, well- to poorly } \\
\text { sorted, muddy, shelly }\end{array}$ & Pleistocene. \\
\hline Varina Grove unit & $\begin{array}{l}\text { Fine to coarse quartz sand, poorly sorted, } \\
\text { muddy, gravelly }\end{array}$ & Pleistocene. \\
\hline $\begin{array}{l}\text { Chowan River Formation, } \\
\text { Coharie Member }\end{array}$ & $\begin{array}{l}\text { Fine to coarse quartz sand, poorly sorted, } \\
\text { clayey, silty }\end{array}$ & Pleistocene. \\
\hline Duplin Formation & $\begin{array}{l}\text { Fine to medium quartz sand; mollusk } \\
\text { shells often abundant }\end{array}$ & Pliocene. \\
\hline Castle Hayne Limestone & $\begin{array}{l}\text { Fine to medium silty calcite-quartz sand, } \\
\text { well-sorted }\end{array}$ & Middle Eocene. \\
\hline Donoho Creek Formation & $\begin{array}{l}\text { Fine to medium silty calcareous quartz } \\
\text { sand, glauconitic, locally shelly; contains } \\
\text { scattered round quartz granules }\end{array}$ & Upper Cretaceous. \\
\hline Bladen Formation & $\begin{array}{l}\text { Fine to coarse silty calcareous quartz sand, } \\
\text { locally shelly, poorly sorted, glauconitic }\end{array}$ & Upper Cretaceous. \\
\hline
\end{tabular}


Table 1. Age and relative position of stratigraphic units in map area.—Continued

\begin{tabular}{|c|c|c|}
\hline Unit & Lithology & Age \\
\hline Tar Heel Formation & $\begin{array}{l}\text { Fine to coarse quartz sand, silty and } \\
\text { clayey, pyritic, lignitic, dense; interbedded } \\
\text { with dense clays }\end{array}$ & Upper Cretaceous. \\
\hline Cape Fear Formation & $\begin{array}{l}\text { Fine to coarse feldspathic quartz sand, silty } \\
\text { and clayey, dense, varicolored }\end{array}$ & Upper Cretaceous. \\
\hline Pleasant Creek Formation ${ }^{1}$ & $\begin{array}{l}\text { Silt, clayey, sandy (very fine), dense, } \\
\text { varicolored; interbedded with fine to } \\
\text { medium quartz sand and dense, } \\
\text { varicolored clays }\end{array}$ & Upper Cretaceous. \\
\hline
\end{tabular}

${ }^{1}$ Within map area, but not augered 
Table 2. Nomenclature and maximum elevation for terrace units used in map area.

\begin{tabular}{|c|c|c|c|c|c|}
\hline Map unit names & $\begin{array}{l}\text { Equivalent unit names in } \\
\text { southern North Carolina } \\
\text { (and South Carolina) }\end{array}$ & $\begin{array}{l}\text { Overlying surface } \\
\text { (Virginia names) }\end{array}$ & $\begin{array}{l}\text { Overlying surface } \\
\text { (Carolina names) }\end{array}$ & $\begin{array}{l}\text { Maximum elevation } \\
\text { (feet) }\end{array}$ & Intervening scarp \\
\hline \multirow[t]{2}{*}{$\begin{array}{l}\text { Chowan River } \\
\text { Formation }\end{array}$} & & Ashland Plain $^{1}$ & Coharie terrace & 235 & \\
\hline & & & & & Broad Rock scarp. \\
\hline \multirow[t]{2}{*}{ Varina Grove unit } & & Essex Plain $^{1}$ & Sunderland terrace & 182 & \\
\hline & & & & & Parler scarp. \\
\hline \multirow{2}{*}{$\begin{array}{l}\text { Waccamaw } \\
\text { Formation }\end{array}$} & & Norge Uplands & Okefenokee terrace & 137 & \\
\hline & & & & & Surry scarp. \\
\hline \multirow[t]{2}{*}{ Windsor Formation } & & Lackey Plain & Wicomico terrace & 105 & \\
\hline & & & & & Ruthville scarp. \\
\hline \multirow{2}{*}{$\begin{array}{l}\text { Charles City } \\
\text { Formation }\end{array}$} & & Grove Plain & Penholoway terrace & 80 & \\
\hline & & & & & Lee Hall scarp. \\
\hline \multirow[t]{2}{*}{$\begin{array}{l}\text { Chuckatuck } \\
\text { Formation }\end{array}$} & $\begin{array}{l}\text { Canepatch Formation, } \\
\text { (Ladson Formation) }\end{array}$ & Grafton Plain & Upper Talbot terrace & 62 & \\
\hline & & & & & Kings Mill scarp. \\
\hline \multirow[t]{2}{*}{ Shirley Formation } & $\begin{array}{l}\text { Flanner Beach Formation, } \\
\text { (Ten Mile Hill beds) }\end{array}$ & Huntington Flat & Lower Talbot terrace & 49 & \\
\hline & & & & & Suffolk scarp. \\
\hline \multirow[t]{3}{*}{ Tabb Formation } & Socastee Formation & Todds Flat & Pamlico terrace & 26 & \\
\hline & (Wando Formation) & & Princess Anne terrace & 17 & \\
\hline & & & Silver Bluff terrace & 7 & \\
\hline
\end{tabular}

${ }^{1}$ Name introduced in Weems and Lewis (2007) 


\section{Appendix 1. Locality Descriptions and Detailed Lithologic Logs}

(Sands are quartz sands unless otherwise indicated.)

\section{Abbotsburg Quadrangle}

AB-1-07: $5.9 \mathrm{mi}$ west of eastern quadrangle border, $7.15 \mathrm{mi}$ north of southern quadrangle border, in northwestern $1 / 9$ th of map area (latitude $34.6027^{\circ} \mathrm{N}$., longitude $78.7287^{\circ} \mathrm{W}$.). Surface elevation $115 \mathrm{ft}$.

\section{LITHOLOGY}

DEPTH, IN FEET

Fill material. $0-0.5$

\section{UNCONFORMITY}

\section{Waccamaw Formation, Bahramsville unit}

Sand, fine, silty, slightly clayey; yellowish brown (10YR 5/2) with

dusky-yellowish-brown (10YR 2/2) mottles, grading down to

yellowish gray $(5 Y$ 6/2)

Sand, fine, slightly silty; pale yellowish gray ( $5 Y$ 8/2) with dusky-yellowish-brown (10YR 2/2) streaks

Sand, dominantly fine (but can be very fine to medium), silty, clayey; grayish-brown (5YR 4/2) with light-brown (5YR 5/6) mottles ....

Sand, poorly sorted, fine to very coarse, granular, slightly silty; grayish brown (5YR 4/2) with light-brown (5YR 5/6) mottles grading down around $8 \mathrm{ft}$ to yellowish gray (5Y 8/1); lower contact somewhat gradational

Sand, very fine to fine, well-sorted, pale-yellowish-gray (5Y 9/1);

bottom 4 inches (in.) dark orange (10YR 8/6) ....

Sand, very fine, clayey; grades down to very fine to fine, silty, slightly clayey, soft; olive gray (5Y 4/1)

Sand, fine to medium, silty, slightly clayey, soft; sparse fine mica; olive gray ( $5 Y$ 4/1)

\section{Waccamaw Formation, James City Member}

Sand, fine, light-olive-gray (5Y 7/1); very abundant aragonitic shell hash; lower contact somewhat gradational

Sand; very fine to fine, light-olive-gray (5Y 7/1); coarsens downward to fine to medium; abundant calcite silt and aragonite shells; rounded phosphate pebbles up to $2 \mathrm{~cm}$ in diameter abundant near base..... 


\section{Tar Heel Formation}

Sand, fine to medium, clayey, dense, medium brownish gray

( $5 Y R$ 5/1); grades down to very fine to fine, silty, clayey,

dense, finely micaceous sand that is dark greenish gray (5G 4/1) with

pale-greenish-gray (5GY 7/1) mottles .

$42-46$

Base of Waccamaw Formation, Bahramsville unit:

$+90 \mathrm{ft}$ above sea level

Base of Waccamaw Formation, James City member:

$+73 \mathrm{ft}$ above sea level

\section{Bottomed in Tar Heel Formation}


AB-2-07: 6.2 mi west of eastern quadrangle border, 1.6 mi north of southern quadrangle border, in southwestern 1/9th of map area (latitude $34.5232^{\circ} \mathrm{N}$., longitude $78.7330^{\circ} \mathrm{W}$.). Surface elevation about $110 \mathrm{ft}$.

LITHOLOGY

DEPTH, IN FEET

Fill, silty, fine sand $0-2$

\section{UNCONFORMITY}

\section{Waccamaw Formation, Bahramsville unit}

Sand, very fine to fine, silty; grayish brown (10YR 4/2) grading down through yellowish gray (5Y 7/2) to dark yellowish orange

(10YR 6/6 to 10YR 7/6)

Sand, very fine, silty, clayey, grayish-yellow (5Y 7/4)

Silt, very clayey, sandy (very fine), yellowish-gray (5Y 8/1);

slightly sticky.....

Sand; very fine grading down rapidly to fine to medium;

light gray ( $N 7)$...

Clay, silty, dense, stiff; medium gray ( $N 5$ ) grading down through grayish brown (5YR 4/2) with greenish-gray (5GY 6/1) mottles (16-17 ft) and medium gray $(N 5)$ (17 to $19 \mathrm{ft}$ ) then back to grayish brown (5YR 4/2)

Clay, dense, sticky, slightly greasy; scattered medium to coarse, subrounded quartz grains increasingly abundant downward; dark olive gray (5Y 3/1) grading down through dark olive gray (5Y 3/1) with dark-greenish-gray ( $5 G$ 4/1) mottles (24-26 ft) to all dark greenish gray $(5 G 4 / 1)$

Silt, very clayey, sticky, greasy; sparse very fine mica; light olive gray ( $5 Y$ 5/2); fragment of olive-brown (5Y 3/4) wood

Sand, very fine to fine, silty, clayey, olive-brown (5Y 3/4). $41-42$

\section{Waccamaw Formation, James City Member}

Coquina; mostly fragments of oyster shell in matrix of silty and clayey fine sand; medium dark gray $(N 4)$

Sand, fine to medium, olive-gray ( $5 Y 3 / 2)$; sparse shells and fragments of dark-reddish-brown (10R 3/4) wood.

Sand, very fine, silty, clayey, dark-greenish-gray (5GY 4/1);

abundant dark-reddish-brown (10R 3/4) lignite fragments

Sand; fine to medium grading down to medium to coarse in basal

foot; dark greenish gray ( $5 G Y 4 / 1)$; rounded clasts of

dark-reddish-brown (10R 3/4) lignite up to $2 \mathrm{~cm}$ in diameter 


\section{Tar Heel Formation}

Silt, very clayey, dense, lignitic; dark greenish gray (5GY 4/1)

grading down to olive gray (5Y 4/1)

$.57-61$

Base of Waccamaw Formation, Bahramsville unit:

Base of Waccamaw Formation, James City Member:

$+68 \mathrm{ft}$ above sea level

$+53 \mathrm{ft}$ above sea level

\section{Bottomed in Tar Heel Formation}


AB-3-07: 1.5 mi west of eastern quadrangle border, 1.4 mi north of southern quadrangle border, in southeastern 1/9th of map area (latitude $34.5204^{\circ} \mathrm{N}$., longitude $78.6503^{\circ} \mathrm{W}$.). Surface elevation about $100 \mathrm{ft}$.

\section{LITHOLOGY}

DEPTH, IN FEET

\section{Waccamaw Formation, Bahramsville unit}

Silt, sandy (very fine), slightly clayey; grayish yellow (5Y 7/4)

grading down through dark yellowish orange (10YR 6/6) to

medium brown (5Y 4/6)

Silt, very clayey, medium-brown (5Y 4/6)

Clay, dense, silty; yellowish gray ( $5 Y 7 / 1$ ) grading down (at $11 \mathrm{ft}$ )

to yellowish gray (5Y 7/1) with pale-yellowish-gray (5Y 8/2) mottles

and dark yellowish orange (10YR 6/6); lower contact gradational.

Clay, greasy, silty, dark-olive-gray ( $5 Y 3 / 1)$; softer than interval above;

scattered laminae of very fine sand; lower contact gradational

\section{Waccamaw Formation, James City Member}

Sand, very fine to fine, silty, dark-gray $(N 3)$

Sand, fine to medium, silty; grades down to fine to coarse, poorly sorted, silty and clayey; light gray $(N 7)$ grading down to medium dark gray $(N 4)$; abundant mollusk shells and black, subrounded phosphate pebbles up to $2 \mathrm{~cm}$ in diameter

\section{Tar Heel Formation}

Clay, silty, dense, massive, dark-olive-gray (5Y 3/1); pervasive

Base of Waccamaw Formation, Bahramsville unit: Base of Waccamaw Formation, James City Member:
$+77 \mathrm{ft}$ above sea level

$+73 \mathrm{ft}$ above sea level

\section{Bottomed in Tar Heel Formation}


AB-4-07: $1.95 \mathrm{mi}$ west of eastern quadrangle border, $7.55 \mathrm{mi}$ north of southern quadrangle border, in northeastern 1/9th of map area (latitude $34.6092^{\circ} \mathrm{N}$., longitude $78.6587^{\circ} \mathrm{W}$.). Surface elevation about $122 \mathrm{ft}$.

LITHOLOGY

DEPTH, IN FEET

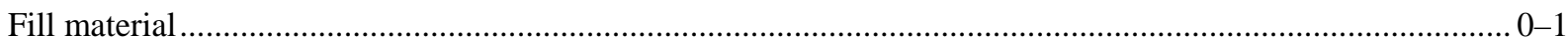

\section{UNCONFORMITY}

\section{Waccamaw Formation, Bahramsville unit}

Sand, very fine to fine with scattered medium grains, silty, slightly

clayey; grayish brown (5YR 3/2) grading down through light yellowish

brown (10YR 6/4) (2-3 ft) and dark yellowish orange

(10YR 6/6) (3-4 ft) to pale brown (5YR 5/2).

Sand; very fine to medium, dominantly fine; moderately well

sorted; silty; pale yellowish orange (10YR $8 / 6)$ grading down through

light olive gray $(5 Y 5 / 2)(8-10 \mathrm{ft})$ to dark olive gray $(5 Y 3 / 1)$

Silt, very clayey, greasy; massive texture; medium greenish

gray $(5 G Y 5 / 1)$...

Silt, very clayey; scattered fine to medium quartz grains

and wood chips; grayish green ( $5 G 5 / 2$ ); lower contact

somewhat gradational

Sand, fine to medium; scattered subrounded quartz granules;

yellowish gray $(5 Y 8 / 1)$

\section{UNCONFORMITY}

\section{Tar Heel Formation}

Clay, silty, very stiff, olive-gray ( $5 Y$ 4/1); wood chips and occasional thin laminae of very fine to fine sand 33-36

Base of Waccamaw Formation, Bahramsville unit:

$+89 \mathrm{ft}$ above sea level

\section{Bottomed in Tar Heel Formation}


AB-5-07: $3.35 \mathrm{mi}$ west of eastern quadrangle border, $5.05 \mathrm{mi}$ north of southern quadrangle border, in central 1/9th of map area (latitude $34.5636^{\circ} \mathrm{N}$., longitude $78.6862^{\circ} \mathrm{W}$.). Surface elevation about $130 \mathrm{ft}$.

\section{LITHOLOGY}

DEPTH, IN FEET

\section{Waccamaw Formation, Moorings unit}

Sand, fine, silty and clayey; medium grayish brown (5YR 4/2)

grading down through pale grayish orange (10YR 8/4) (4-8 in.)

to dark yellowish orange (10YR 6/6).....

Sand, very fine to fine, silty and clayey, dark-yellowish-orange $(10 Y R$ 6/6) .................................................. 2-3

Sand, very fine to fine, silty; yellowish gray ( $5 Y 7 / 2)$ with sparse

light-brown (5YR 5/6) mottles

Sand, very fine to fine, silty, pale-grayish-orange (10YR 8/4);

abundant very fine mica

Sand, very fine to fine, silty; abundant very fine mica; pale red

(10R 6/2) grading down through yellowish orange (10YR 7/6)

intermingled with white $(N$ 9) to light yellowish brown (10YR 6/4)

Sand, fine, humic; dusky brown (5YR 2/2) grading down to pale

brown (5YR 5.5/2); lower contact somewhat gradational

Sand, fine to coarse, poorly sorted, clean, medium-brown (5Y 4/6)

Sand, fine to very coarse, poorly sorted, clean; medium brown

(5Y 4/6) grading down through medium yellowish brown (10YR 5/4)

(22-24 ft) to pale grayish orange (10YR 8/4); lower contact gradational

Sand, very fine to fine, clean; yellowish brown (10YR 5/2) with streaks of pale grayish orange (10YR 8/4) and yellowish orange $(10 Y R$ 7/6) in basal $2 \mathrm{ft}$

\section{Waccamaw Formation, Bahramsville unit}

Silt, very clayey, sandy (very fine); pale olive gray (5Y 7/1)

with dark-yellowish-orange (10YR 5/6) mottles

Sand, fine to coarse, poorly sorted, subrounded, silty; grayish orange (10YR 7/4) grading to yellowish orange (10YR 7/6)

at $43 \mathrm{ft}$ with reddish-brown (10R 5/6), and pale-yellowish-gray

$(5 Y 8 / 2)$ streaks $41-46$

Sand, fine to coarse, poorly sorted; sparse quartz granules;

yellowish orange (10YR 7/6); lower contact somewhat gradational $46-52$

Sand, fine, well-sorted; slightly silty but fairly clean; dark gray ( $N 3$ ) $52-58$

Silt, very clayey, medium-gray ( $N$ 5); 1-cm-diameter, sand-filled burrows below $62 \mathrm{ft}$; lower contact somewhat gradational.

Sand, fine to coarse, poorly sorted, medium-gray ( $N$ 5); contains lignite clasts of Tar Heel Formation reworked from unit below 


\section{Tar Heel Formation}

Clay, silty, massive, very dense, olive-gray (5Y 4/1);

abundant dusky-brown (5YR 2/2) lignite

73-76

Base of Waccamaw Formation, Moorings unit:

$+90 \mathrm{ft}$ above sea level

Base of Waccamaw Formation, Bahramsville unit:

$+57 \mathrm{ft}$ above sea level

Bottomed in Tar Heel Formation 


\section{Ammon Quadrangle}

AM-1-05: $0.39 \mathrm{mi}$ west of eastern quadrangle border, $3.81 \mathrm{mi}$ north of southern quadrangle border, in east-central 1/9th of map area, along road into Smith Bay, $0.3 \mathrm{mi}$ from end of road (latitude $34.8040^{\circ} \mathrm{N}$., longitude $78.5067^{\circ} \mathrm{W}$.). Surface elevation $97 \mathrm{ft}$.

\section{LITHOLOGY}

DEPTH, IN FEET

\section{Windsor Formation}

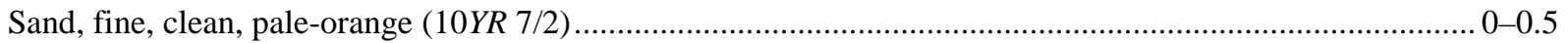

Sand, fine to medium, very humic, brownish-black $(10 Y R$ 2/1) ………........................................................... 0.5-3

Sand, fine to medium, less humic than interval above; dark yellowish

brown $(10 Y R$ 4/2) ...................

Sand, fine to medium, more humic than interval above; yellowish

brown $(10 Y R$ 3/1)

Sand; medium to coarse grading down to medium to very coarse;

subrounded; slightly humic; yellowish brown (10YR 4/4) grading down

through light yellowish brown (10YR 6/4) to pale yellowish gray

(5Y 7/2); lower contact somewhat gradational.....

Sand, fine, silty, woody, light-olive-gray (5Y 5/2)

Silt, sandy (very fine), clayey; denser than interval above; pale olive gray

$(5 Y 7 / 1)$

\section{UNCONFORMITY}

\section{Tar Heel Formation}

Silt, very clayey, micaceous, dark-greenish-gray (5GY 4/1); very

dense and sticky

Sand, very fine to fine, very micaceous, very lignitic, dark-greenishgray $(5 G Y 4 / 1)$

Silt, very clayey, micaceous, dark-greenish-gray (5GY 4/1); very

dense and sticky

\section{Bottomed in Tar Heel Formation}


AM-2-05: $3.50 \mathrm{mi}$ west of eastern quadrangle border, $1.78 \mathrm{mi}$ north of southern quadrangle border, along northern side of road north of Charlie Long Millpond, 0.75 mi east of intersection with North Carolina State Road 1505 in southcentral 1/9th of map area (latitude $34.7758^{\circ} \mathrm{N}$., longitude $78.5614^{\circ} \mathrm{W}$.). Surface elevation $93 \mathrm{ft}$.

\section{LITHOLOGY}

DEPTH, IN FEET

\section{Windsor Formation}

Sand; fine with sparse medium grains; soft; grayish yellow (5Y 7/4)

Sand; fine with sparse medium grains; silty; stiff; dusky yellowish orange $(10 Y R 5 / 6)$.

Sand, fine to medium, slightly silty, yellowish-orange (10YR 5/6);

much softer than interval above

Sand, fine to medium, thixotropic, light yellowish brown (10YR 6/4);

lower contact somewhat gradational...

Sand, medium to coarse, yellowish-orange (10YR 7/6), soft, thixotropic; lower contact gradational.

Sand, medium to very coarse, subangular to subrounded; abundant subangular to subrounded quartz granules in basal foot; yellowish orange (10YR 7/6); soft and thixotropic.

\section{Tar Heel Formation}

Silt, sandy (very fine), stiff, micaceous, dark-greenish-gray (5GY 4/1); thin stringers or burrows of very fine, clean sand

\section{Bottomed in Tar Heel Formation}


AM-3-05: $6.38 \mathrm{mi}$ west of eastern quadrangle border, $4.82 \mathrm{mi}$ north of southern quadrangle border, along eastern side of North Carolina State Road 1331, $0.05 \mathrm{mi}$ south of power line crossing in west-central 1/9th of map area (latitude $34.8203^{\circ} \mathrm{N}$., longitude $78.6119^{\circ} \mathrm{W}$.). Surface elevation $95 \mathrm{ft}$.

\section{LITHOLOGY}

DEPTH, IN FEET

\section{Windsor Formation}

Sand; fine with sparse medium grains; dark yellowish brown

(10YR 4/2) over pale grayish orange (10YR 8/4); soft......

Sand; fine grading down to fine to medium; pale grayish orange

(10YR 8/4) grading down to dusky yellowish orange (10YR 5/6)

Sand, fine, silty, clayey, stiffer than interval above; pale yellowish gray

(5Y 8/2) with reddish-orange (10R 7/8) mottles

Sand, medium to coarse, subangular to subrounded, silty; pale

brown (5YR 6/6) grading down to dark yellowish orange

(10YR 6/6); tough drilling

\section{UNCONFORMITY}

\section{Tar Heel Formation}

Silt, clayey; dusky yellowish orange (10YR 5/6) with dark-

yellowish-brown (10YR 4/2) mottles; weathered zone on unit below $11-13$

Silt, dense; scattered very fine sand-filled burrows; dusky greenish gray $(5 G Y 3 / 1)$

\section{Bottomed in Tar Heel Formation}


AM-4-05: $6.38 \mathrm{mi}$ west of eastern quadrangle border, $4.82 \mathrm{mi}$ north of southern quadrangle border, along western side of North Carolina State Road 242, 1.5 mi southwest of intersection with North Carolina State Road 210 in north-central 1/9th of map area (latitude $34.8500^{\circ} \mathrm{N}$., longitude $78.5590^{\circ} \mathrm{W}$.). Surface elevation about $112 \mathrm{ft}$.

\section{LITHOLOGY}

DEPTH, IN FEET

\section{Dune sand}

Sand, fine to medium; pale orange (10YR 7/2) over dark reddish brown (5YR 3/4) with dusky-yellowish-brown (10YR 2/2) streaks.

Sand, medium to coarse, silty; increasingly humic downward;

light yellowish brown (10YR 6/4) grading down through very pale orange

(10YR 8/2) (2 to $4 \mathrm{ft})$ to brownish black (5YR 2/1)

Sand, medium to coarse, silty; very humic and humate cemented;

dark yellowish brown (10YR 4/2) grading rapidly at $9 \mathrm{ft}$ to

dusky yellowish brown (10YR 2/2).

\section{UNCONFORMITY}

\section{Windsor Formation}

Sand; fine grading down to fine to medium; yellowish gray $(5 Y$ 7/2) …………......................................... 11-18

Sand, medium to very coarse, yellowish-gray $(5 Y 7 / 1)$............................................................................ 18-28

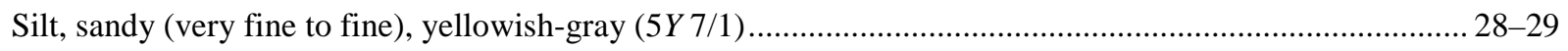

Sand; fine to medium grading down to medium to very coarse;

yellowish gray (5Y 7/1); rounded lignite lumps in basal $2 \mathrm{ft}$

\section{UNCONFORMITY}

\section{Tar Heel Formation}

Silt, clayey, micaceous, lignitic, dusky-greenish-gray (5GY 3/1);

interbedded with very fine, clean, micaceous, lignitic, dark-

grayish-green (5G 4/2) sand.

Base of dune sand:

Base of Windsor Formation:

Bottomed in Tar Heel Formation $+\mathbf{1 0 1} \mathbf{f t}$ above sea level $+64 \mathrm{ft}$ above sea level 


\section{Atkinson Quadrangle}

AT-1-04: $5.55 \mathrm{mi}$ west of eastern quadrangle border, $1.72 \mathrm{mi}$ north of southern quadrangle border, $50 \mathrm{ft}$ northwest of $102-\mathrm{ft}$ spot elevation at intersection of dirt roads in southwestern 1/9th of map area (latitude $34.5252^{\circ} \mathrm{N}$., longitude $78.2213^{\circ} \mathrm{W}$.). Surface elevation $102 \mathrm{ft}$.

\section{LITHOLOGY}

DEPTH, IN FEET

\section{Dune sand}

Sand, fine to coarse but dominantly medium, poorly sorted, mostly subangular, clean; dark yellowish brown (10YR 3/2) grading down through medium yellowish brown (10YR 5/4) to yellowish orange $(10 Y R$ 7/6).....

Sand; fine to coarse, dominantly medium; poorly sorted; mostly subangular; clean; grayish orange (10YR 7/4) grading down through dark yellowish brown (10YR 4/2) (2.5-3.5 ft) to pale yellowish brown $(10 Y R$ 6/2)

Sand; fine to coarse, dominantly medium; poorly sorted; mostly subangular; clean; dusky yellowish brown (10YR 2/2); thixotropic

Sand; fine to coarse, dominantly medium; poorly sorted; occasional lenses of fine sand cemented by humate; dark reddish brown (5YR 3/4); wood clast near base

\section{UNCONFORMITY}

\section{Charles City Formation}

Sand; mostly fine with some medium; silty and slightly clayey; medium brown (5YR 4/6) grading to light yellowish

Silt, clayey to very clayey, sandy (very fine), finely micaceous, light-olive-gray (5Y 6/1); much stiffer than interval above; lower contact somewhat gradational

Sand, very fine to fine, very silty and moderately clayey, stiff, light-

olive-gray (5Y 6/1); lower contact somewhat gradational

Sand, fine to coarse, poorly sorted, silty and clayey, stiff, grayishyellowish-green (10GY 6/2); sparse subangular to subrounded quartz pebbles up to $1 \mathrm{~cm}$ in diameter

\section{Windsor Formation}

Silt, very clayey, stiff and dense; sparse very fine sand grains; woody; dark grayish green (5GY 4/2); becomes sandier downward; lower contact somewhat gradational.....

Sand; fine to medium grading down to medium to coarse; silty; medium gray $(N 5)$; quartz pebbles and a few clayballs up to $1 \mathrm{~cm}$ in diameter at base.... 
Sand; fine to medium grading to coarse to very coarse; medium

gray $(N 5)$; abundant subrounded quartz pebbles up to $1 \mathrm{~cm}$ in diameter;

some clayballs

\section{UNCONFORMITY}

\section{Bladen Formation}

Sand, fine to medium, silty, clayey, dark-olive-gray (5Y 2/2) .

69-76

Base of dune sand:

Base of Charles City Formation:

Base of Windsor Formation:

$+74 \mathrm{ft}$ above sea level

$+54.5 \mathrm{ft}$ above sea level

$+33 \mathrm{ft}$ above sea level

Bottomed in Bladen Formation 
AT-2-04: $1.93 \mathrm{mi}$ west of eastern quadrangle border, $0.82 \mathrm{mi}$ north of southern quadrangle border, beside dirt road 0.15 mi south of the letter "D" in the word "RAILROAD" (see label on quadrangle map) in southeastern 1/9th of map area (latitude $34.5124^{\circ} \mathrm{N}$., longitude $78.1581^{\circ} \mathrm{W}$.). Surface elevation $55 \mathrm{ft}$.

\section{LITHOLOGY}

DEPTH, IN FEET

\section{Chuckatuck Formation}

Sand, very fine, silty and clayey, dark-yellowish-orange (10YR 6/6) $0-1$

Silt, sandy (very fine), clayey, stiff, dense, slightly sticky; medium brown

(5YR 5/6) with light-yellowish-gray (5Y 7/1) mottles below

$3 \mathrm{ft}$ that increase in abundance downward ....

Sand, fine to coarse, poorly sorted, angular to subangular, granular, clayey and

silty; medium brown (5YR 5/6) with light-yellowish-gray (5Y 7/1) mottles

Sand, fine to coarse, poorly sorted, subangular to subrounded, pebbly,

slightly silty, soft, light-brown (5YR 6/4).

\section{UNCONFORMITY}

\section{Charles City Formation}

Silt, clayey, greasy, massive, sandy (very fine), dark-greenish-gray

(5GY 4/1); becomes sandier downward

Sand, fine to very fine, silty, dark-greenish-gray (5GY 4/1);

quartz pebbles up to $1 \mathrm{~cm}$ in diameter and wood fragments

\section{UNCONFORMITY}

\section{Bladen Formation}

Sand, fine, well-sorted, dark-greenish-gray ( $5 G Y 3 / 1)$; sparse quartz

pebbles and dense clayballs at base

Dense interval, very slow drilling, no recovery

Sand, fine, well-sorted, silty, dark-grayish-olive (10Y 3/2); more

dense and harder drilling than in sand above

Base of Chuckatuck Formation:

Base of Charles City Formation:

$+44 \mathrm{ft}$ above sea level

$+37 \mathrm{ft}$ above sea level

\section{Bottomed in Bladen Formation}


AT-3-04: $3.07 \mathrm{mi}$ west of eastern quadrangle border, $3.51 \mathrm{mi}$ north of southern quadrangle border, at beginning of dirt road 0.7 mi north-northeast of Woodcock Cemetery in central 1/9th of map area (latitude $34.5513^{\circ} \mathrm{N}$., longitude $78.1782^{\circ} \mathrm{W}$.). Surface elevation $68 \mathrm{ft}$.

\section{LITHOLOGY}

DEPTH, IN FEET

Road fill $0-1$

\section{UNCONFORMITY}

\section{Charles City Formation}

Sand, very fine, silty and clayey; dark yellowish brown (10YR 3/2)

grading downward to yellowish orange (10YR 7/6) with

light-yellowish-gray (5Y 7/1) mottles

Silt, clayey, sandy (very fine); light yellowish gray (5Y 7/1) (6-7 ft)

grading down to light olive gray (5Y 6/1)

Sand; mostly fine grading down to fine to medium; angular to subangular; silty and clayey; medium dark gray $(N 4)$ grading down to dark greenish gray ( $5 G 4 / 1)$; lower contact gradational

Sand, medium to coarse, subangular, silty, very porous and permeable, olive-gray ( $5 Y$ 4/2); subrounded quartz pebbles up to $1 \mathrm{~cm}$ in diameter in basal foot

\section{UNCONFORMITY}

\section{Bladen Formation}

Sand, fine to medium, well-sorted, silty and slightly clayey, olive-gray ( $5 Y 3 / 2)$; scattered rounded quartz granules; includes parts of two adjacent fining-upward cycles that break at $33 \mathrm{ft}$

\section{Base of Charles City Formation:}

\section{Bottomed in Bladen Formation}


AT-4-04: $5.41 \mathrm{mi}$ west of eastern quadrangle border, $7.01 \mathrm{mi}$ north of southern quadrangle border, at southwestern corner of field $0.3 \mathrm{mi}$ north-northeast of Cypress Lake in northwestern 1/9th of map area (latitude $34.6018^{\circ} \mathrm{N}$., longitude $78.2193^{\circ} \mathrm{W}$.). Surface elevation $85 \mathrm{ft}$.

\section{LITHOLOGY}

DEPTH, IN FEET

\section{Dune sand}

Sand; fine grading down to fine to medium at base; well-sorted; silty; pale yellowish brown $10 Y R$ 6/2) grading down through dusky yellowish brown (10YR 2/2) to dark reddish brown (5YR 3/4).

Sand, fine, silty; grayish yellow ( $5 Y 5 / 4)$ grading down to dark yellowish brown $(10 Y R$ 4/2) ....

Sand, fine, silty, humic, dusky-brown (10YR 2/2) .

Sand, fine to medium; medium fraction angular; dark reddish brown (5YR 3/4) grading down to dusky brown (10YR 2/2)

\section{UNCONFORMITY}

\section{Charles City Formation}

Sand; fine grading down to very fine; silty and clayey; dusky yellow (5Y 6/4); much denser and stiffer than unit above, lower contact somewhat gradational

Silt, very clayey, sandy (very fine), pale-olive-gray (5Y 6/2);

dense and stiff; lower contact gradational.

Sand, very fine, silty and clayey, pale-olive-gray ( $5 Y$ 6/2);

softer than interval above; sparse pebbles and wood chips

near basal contact

\section{UNCONFORMITY}

\section{Windsor Formation}

Silt, clayey, sandy (very fine), dense and stiff, dark-greenishgray $(5 G 4 / 1)$.

Sand; fine to medium grading to medium to coarse near base; feldspathic; clean; medium olive gray ( $5 Y 5 / 1)$; thixotropic; quartz pebbles up to $1 \mathrm{~cm}$ in diameter 


\section{Bladen Formation}

Sand, fine, silty to silty and clayey, dark-greenish-gray (5GY 3/1);

much denser than unit above.

$42-46$

Base of dune sand:

Base of Charles City Formation:

Base of Windsor Formation:

$+77 \mathrm{ft}$ above sea level

$+63 \mathrm{ft}$ above sea level

$+43 \mathrm{ft}$ above sea level

Bottomed in Bladen Formation 
AT-5-04: $1.26 \mathrm{mi}$ west of eastern quadrangle border, $7.49 \mathrm{mi}$ north of southern quadrangle border, $0.7 \mathrm{mi}$ northwest of Marshburn Cemetery in northeastern 1/9th of map area (latitude $34.6088^{\circ} \mathrm{N}$., longitude $78.1466^{\circ} \mathrm{W}$.). Surface elevation $66 \mathrm{ft}$.

\section{LITHOLOGY}

DEPTH, IN FEET

\section{Charles City Formation}

Sand, very fine to fine, silty, slightly clayey; dark yellowish brown (10YR 3/2) grading down through light yellowish brown (10YR 6/4) to yellowish orange (10YR 7/6)

Sand, very fine to fine, silty, slightly clayey; yellowish orange

(10YR 7/6) with yellowish-gray (5Y 7/2) mottles grading down through

yellowish orange (10YR 7/6) with yellowish-gray (5Y 7/2) mottles

and medium reddish brown (10R 4/6) to yellowish gray

(5Y 7/2) with yellowish-orange (10YR 7/6) mottles

Silt, clayey, sandy (very fine to medium); light brown (5YR 5/6)

grading rapidly to dark yellowish orange (10YR 6/6); lower contact

somewhat gradational

Sand, fine to medium, silty and slightly clayey, light-yellowish-

brown (10YR 6/4), lower contact somewhat gradational

Sand, fine to coarse, poorly sorted, silty, medium-gray $(N 5)$;

clayey and pebbly in basal foot; subrounded quartz pebbles

up to $3 \mathrm{~cm}$ in diameter

\section{UNCONFORMITY}

\section{Bladen Formation}

Sand, fine to medium, silty, olive-gray (5Y 3/2)

$20-26$

\section{Base of Charles City Formation:}

$+46 \mathrm{ft}$ above sea level

\section{Bottomed in Bladen Formation}




\section{Autryville Quadrangle}

AU-1-05: $0.96 \mathrm{mi}$ west of eastern quadrangle border, $4.50 \mathrm{mi}$ north of southern quadrangle border, at entrance to farm road on western side of North Carolina State Road 2030, 1.1 mi south-southeast of Union Hill Church in east-central 1/9th of map area (latitude $34.9405^{\circ} \mathrm{N}$., longitude $78.6416^{\circ} \mathrm{W}$.). Surface elevation $112 \mathrm{ft}$.

\section{LITHOLOGY}

DEPTH, IN FEET

\section{Waccamaw Formation, Bahramsville unit}

Sand, very fine to fine, silty, slightly clayey; brownish black

(5YR 5/1) overlying dark yellowish brown (10YR 5/4)....

Sand, very fine to fine, silty, slightly clayey; dusky yellowish brown (10YR 5/6) with light-brown (5YR 5/6) mottles;

lower contact somewhat gradational

Sand, fine to medium, silty, subangular, medium-gray $(N 5)$

Sand; fine to medium grading down to medium to coarse; silty; yellowish brown (5YR 5/2) grading down through pale yellowish gray (5Y 8/2) and pale grayish orange (10YR $8 / 4)$ to yellowish gray $(5 Y$ 8/1).

Sand, fine to medium, very silty and clayey, very-pale-orange (10YR 8/2)

Sand, medium to very coarse, silty; pale yellowish gray (5Y 8/2)

grading to medium gray $(N 5)$ at about $24 \mathrm{ft}$; subrounded to rounded quartz

pebbles up to $1.5 \mathrm{~cm}$ in diameter at top; pebbles become subangular to

subrounded downward and increase in diameter to a maximum of $2.5 \mathrm{~cm}$.

Sand, fine to medium, very silty, micaceous, medium-gray ( $N$ 5);

subrounded to rounded quartz pebbles up to $1 \mathrm{~cm}$ in diameter

and wood chips (mostly concentrated at base).

\section{UNCONFORMITY}

\section{Tar Heel Formation}

Sand; fine grading down to fine to medium; silty; slightly clayey; very micaceous; very lignitic; sulfurous odor; medium greenish gray (5G $5 / 1$ );

a few dark-greenish-gray (5GY 3/1), clayey silt lenses $31-46$

\section{Base of Waccamaw Formation, Bahramsville unit:}

\section{Bottomed in Tar Heel Formation}


AU-2-05: $3.53 \mathrm{mi}$ west of eastern quadrangle border, $1.58 \mathrm{mi}$ north of southern quadrangle border, at entrance to dirt road on southwest side of North Carolina State Road 1002, $0.45 \mathrm{mi}$ southeast of St. Marks Church in south-central 1/9th of map area (latitude $34.8980^{\circ} \mathrm{N}$., longitude $78.6870^{\circ} \mathrm{W}$.). Surface elevation $111 \mathrm{ft}$.

\section{LITHOLOGY}

DEPTH, IN FEET

\section{Waccamaw Formation, Bahramsville unit}

Sand, fine to medium, clean; brownish black (5YR 2/1)

overlying pale yellowish brown (10YR 6/2) overlying

dark yellowish brown $(10 Y R 3 / 4)$

Silt, clayey, sandy (very fine); dark yellowish brown (10YR 4/2)

grading down through dusky yellowish brown (10YR 2/2) to yellowish

brown $(10 Y R 5 / 2)$ at about $6 \mathrm{ft}$

Sand, very fine to fine, silty, yellowish-brown (10YR 5/2)

Sand; fine grading down through fine to medium to medium to very coarse; quartz pebbles at base; pale yellowish brown (10YR 6/2).

\section{Tar Heel Formation}

Silt, dense, very clayey; sparse lignite and mica; dusky greenish gray $(5 G Y 3 / 1)$

\section{Bottomed in Tar Heel Formation}


AU-3-05: $5.64 \mathrm{mi}$ west of eastern quadrangle border, $4.61 \mathrm{mi}$ north of southern quadrangle border, at entrance to dirt road (not on map) on northwestern side of North Carolina State Road 2024, 1.05 mi northeast of Cedar Creek Lookout Tower in west-central $1 / 9$ th of map area (latitude $34.9422^{\circ} \mathrm{N}$., longitude $78.7237^{\circ} \mathrm{W}$.). Surface elevation $118 \mathrm{ft}$.

\section{LITHOLOGY}

DEPTH, IN FEET

\section{Waccamaw Formation, Bahramsville unit}

Sand, fine to medium, silty; dusky yellowish brown (10YR 2/2)

overlying pale yellowish brown (10YR 6/2) with dark-

yellowish-orange (10YR 6/6) mottles

Silt, sandy (very fine), clayey, stiff; yellowish brown (10YR 5/2)

with dark-yellowish-orange (10YR 6/6) mottles grading down to pale

olive gray (5Y 7/1) $1-6$

Sand, very fine to fine, very silty and clayey, pale-olive-gray (5Y 7/1)

Sand; fine to medium grading down to medium to coarse; slightly

silty; yellowish gray ( $5 Y 8 / 1$ ) grading down to light olive gray

(5Y 6/1); subangular quartz pebbles up to $1 \mathrm{~cm}$ in

diameter toward base

\section{UNCONFORMITY}

\section{Tar Heel Formation}

Silt, dense, very clayey, sparsely lignitic and micaceous, duskygreenish-gray (5GY 3/1)

Sand, fine to medium, very micaceous and lignitic, medium- to

light-greenish-gray (5GY 7/1)

Silt, very clayey, dense, sparsely lignitic and micaceous, duskygreenish-gray (5GY 3/1)

\section{Bottomed in Tar Heel Formation}


AU-4-05: $3.91 \mathrm{mi}$ west of eastern quadrangle border, $7.07 \mathrm{mi}$ north of southern quadrangle border, at old home site on southeastern side of North Carolina State Road 2022, 1.95 mi west of Christian Light Church in north-central 1/9th of map area (latitude $34.9776^{\circ} \mathrm{N}$., longitude $78.6933^{\circ} \mathrm{W}$.). Surface elevation $122 \mathrm{ft}$.

\section{LITHOLOGY}

DEPTH, IN FEET

\section{Waccamaw Formation, Bahramsville unit}

Sand, very fine to fine, silty, clayey; dark yellowish brown

(10YR 3/2) over dark yellowish orange (10YR 6/6).

Sand; very fine to fine grading down to fine to medium; silty and clayey; yellowish gray (5Y 8/1) grading down through light grayish orange (10YR 7/8) to yellowish orange (10YR 7/6)

Sand; medium to coarse grading down to medium to very coarse; subangular; slightly silty; pale grayish orange (10YR $8 / 4)$ grading down to pale orange (10YR $8 / 2)$.

Sand, medium to very coarse, pale-grayish-orange (10YR 8/4);

subrounded quartz pebbles up to $1.5 \mathrm{~cm}$ in diameter

\section{Tar Heel Formation}

Sand, very fine to fine, silty and clayey; grades down to fine to medium, very silty, very micaceous, lignitic; top 2 in. light grayish orange (10YR 7/8), dusky greenish gray (5GY 3/1) below

Sand, fine, well-sorted, very micaceous; light gray ( $N 7$ ) (24-25 ft) grading down to dark greenish gray (5GY 3/1); clay lens at $27 \mathrm{ft}$ with lignite fragments $24-27.5$

Sand, coarse, silty, micaceous, dusky-greenish-gray (5GY 3/1) $27.5-31$

Base of Waccamaw Formation, Bahramsville unit: $+104 \mathrm{ft}$ above sea level

\section{Bottomed in Tar Heel Formation}


AU-5-05: $4.47 \mathrm{mi}$ west of eastern quadrangle border, $5.75 \mathrm{mi}$ north of southern quadrangle border, $100 \mathrm{ft}$ northeast of North Carolina State Highway 210 on southern rim of Sewell Bay on boundary between north-central and central 1/9th of map area (latitude $34.9776^{\circ} \mathrm{N}$., longitude $78.6933^{\circ} \mathrm{W}$.). Surface elevation $118 \mathrm{ft}$.

Surface outcrop along back edge of small borrow pit adjacent to road. Took sand sample in polyvinylchloride (PVC) pipe from bay rim to obtain optically stimulated luminescence (OSL) age date. Sample yielded a quartz blue-light OSL age of 13,000 \pm 930 years B.P. (one s.d.) (Shannon A. Mahan, USGS, written commun., 2006). 
AU-6-05: $6.51 \mathrm{mi}$ west of eastern quadrangle border, $3.93 \mathrm{mi}$ north of southern quadrangle border, $400 \mathrm{ft}$ south of Cedar Creek Lookout Tower in west-central $1 / 9$ th of map area (latitude $34.9776^{\circ} \mathrm{N}$., longitude $78.6933^{\circ} \mathrm{W}$.). Surface elevation about $130 \mathrm{ft}$.

\section{LITHOLOGY}

DEPTH, IN FEET

\section{Dune sand}

Sand, fine to medium, soft, clean; dusky yellowish orange (10YR 5/6) grading down through light grayish brown (5YR 4/2) (2-6 ft), pale yellowish gray $(5 Y 8 / 2)(6-7 \mathrm{ft})$, medium yellowish brown (10YR 5/4) (7-8 ft), pale olive brown (5YR 6/6) (8-10 ft), dark olive gray $(5 Y 2 / 2)(10-13 \mathrm{ft})$ to dark yellowish brown $(10 Y R 4 / 4)$..... $0-14$

\section{UNCONFORMITY}

\section{Waccamaw Formation, Bahramsville unit}

Sand, fine, silty, slightly clayey, brownish-gray (5YR 4/1). $14-14.5$

Silt, clayey, sticky, sandy (very fine); yellowish gray (5Y 7/2)

with dark-yellowish-orange (10YR 6/6) mottles below $18 \mathrm{ft}$ $14.5-25$

Sand, very fine to fine, slightly silty, finely micaceous, light-greenish-gray (5G 7/1).....

Base of dune sand:

$+116 \mathrm{ft}$ above sea level

Bottomed in Waccamaw Formation, Bahramsville unit 


\section{Bladenboro Quadrangle}

BB-1-06: $5.62 \mathrm{mi}$ west of eastern quadrangle border, $3.94 \mathrm{mi}$ north of southern quadrangle border, $100 \mathrm{ft}$ east of North Carolina State Road 1128, 0.2 mi south of crossing over CSX Railroad just south of Butters, in west-central 1/9th of map area (latitude $34.5573^{\circ} \mathrm{N}$., longitude $78.8481^{\circ} \mathrm{W}$.). Surface elevation $113 \mathrm{ft}$.

\section{LITHOLOGY}

DEPTH, IN FEET

Sand-pit fill $0-12$

\section{Waccamaw Formation, Bahramsville unit}

Sand, very fine, silty and clayey; abundant cypress(?)

wood shreds; brownish gray (5YR 4/1)

Sand, fine to medium, angular to subangular, rather clean;

yellowish gray (5Y 7/1) grading down at $18 \mathrm{ft}$ to pale

pinkish gray (5YR 9/1)

Sand, medium to very coarse, angular to subangular, clean, dark-yellowish-orange (10YR 6/6)

\section{Duplin Formation(?)}

Silt, sandy (very fine), olive-gray (5Y 3/2).

$24-26$

\section{Tar Heel Formation}

Sand, medium to coarse, slightly micaceous, silty, clayey, dense, pale-bluish-gray (5B 8/1)

Base of Waccamaw Formation, Bahramsville unit: Base of Duplin Formation(?):

Bottomed in Tar Heel Formation
$+89 \mathrm{ft}$ above sea level $+87 \mathrm{ft}$ above sea level 
BB-2-06: $3.48 \mathrm{mi}$ west of eastern quadrangle border, $0.57 \mathrm{mi}$ north of southern quadrangle border, on western side of North Carolina State Road 1177, 0.12 mi north of end of road, south-central 1/9th of map area (latitude $34.5082^{\circ} \mathrm{N}$., longitude $78.8105^{\circ} \mathrm{W}$.). Surface elevation $116 \mathrm{ft}$.

\section{LITHOLOGY}

DEPTH, IN FEET

\section{Waccamaw Formation, Bahramsville unit}

Sand, very fine to fine, silty; dark yellowish brown (10YR 3/2)

grading down to yellowish gray (5Y 6/2) at $1 \mathrm{ft}$.

Sand, very fine to fine, silty; dark yellowish orange (10YR 5/6)

grading to grayish orange pink $(10 Y R$ 7/2) at $4 \mathrm{ft}$

Sand; very fine with scattered medium grains grading down to fine to very fine at $11 \mathrm{ft}$; silty; about 1 percent very fine, dark, heavy minerals; thixotropic; pale yellowish gray (5Y 9/1) with paleyellowish-orange (10YR 8/6) blotches

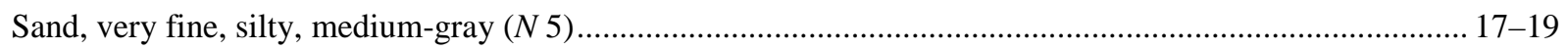

Silt, clayey, sandy (very fine), medium-gray ( $N$ 5)

Sand, very fine, silty, clayey, medium-gray ( $N$ 5); abrupt contact with bed below....

\section{UNCONFORMITY}

\section{Varina Grove unit}

Sand, fine to medium, angular to subangular; grades down to fine and slightly micaceous; silty; medium olive gray (5Y 5/1).

Sand, medium to very coarse, angular to subangular, clayey and silty, dark-gray ( $N 3$ ); possible basal lag bed.....

\section{Bottomed in Varina Grove unit}


BB-3-06: $1.19 \mathrm{mi}$ west of eastern quadrangle border, $4.33 \mathrm{mi}$ north of southern quadrangle border, on sand rim on northwestern border of small bay, $400 \mathrm{ft}$ west-southwest of intersection of North Carolina State Roads 1117 and 1118, east-central 1/9th of map area (latitude $34.5630^{\circ} \mathrm{N}$., longitude $78.7705^{\circ} \mathrm{W}$.). Surface elevation $142 \mathrm{ft}$.

\section{LITHOLOGY}

DEPTH, IN FEET

\section{Waccamaw Formation, Moorings unit}

Sand, very fine to fine, humic; brownish black (5YR 1/1)

grading down through dusky yellowish brown (10YR $2 / 2)$ to

dark reddish brown (5YR 3/4)

Sand, very fine to fine, humic; dusky brown (5YR 2/2)

grading down through medium grayish brown (5YR 4/2)

(3-4 ft) to grayish orange pink (5YR 6/2) .....

Sand, very fine to fine, thixotropic; grayish orange pink

(5YR 6/2) grading down through pale orange (10YR 7/2)

$(9-20 \mathrm{ft})$, dark yellowish orange (10YR 6/6) (20-24 ft),

very dark yellowish orange (10YR 5/6) (24-28 ft),

and pale olive brown (5Y 6/6) (28-36 ft) to dusky

yellow (5Y 6/4).

\section{Waccamaw Formation, Bahramsville unit}

Sand, very fine to fine, silty, clayey; olive gray (5Y 4/2)

grading down to olive gray (5Y 4/1) at $40 \mathrm{ft}$;

interbedded with clayey, sandy (very fine), medium-

greenish-gray $(5 G 5 / 1)$ silt

Sand; medium to coarse grading down to medium to very

coarse; olive gray ( $5 Y 4 / 1)$; subangular to angular quartz

pebbles up to $0.5 \mathrm{~cm}$ in diameter near base; possible basal lag bed.

$52-56$

Base of Waccamaw Formation, Moorings unit:

$+104 \mathrm{ft}$ above sea level

\section{Bottomed in Waccamaw Formation, Bahramsville Member}


BB-4-06: $4.53 \mathrm{mi}$ west of eastern quadrangle border, $7.15 \mathrm{mi}$ north of southern quadrangle border, at southern corner of field located $0.32 \mathrm{mi}$ west-northwest of intersection of North Carolina State Roads 1101 and 1100, north-central 1/9th of map area (latitude $34.6035^{\circ} \mathrm{N}$., longitude $78.8258^{\circ} \mathrm{W}$.). Surface elevation $116 \mathrm{ft}$.

\section{LITHOLOGY}

DEPTH, IN FEET

\section{Waccamaw Formation, Bahramsville unit}

Sand, fine to medium, slightly silty; dark yellowish orange

(10YR 6/6) grading down to very dark yellowish orange (10YR 5/6)

Sand, fine to medium, subangular to angular; dark orange

(10YR 6/8) grading down through yellowish orange (10YR 7/6)

(3-4 ft), yellowish gray $(5 Y 7 / 2)(4-5 \mathrm{ft})$, and medium

yellowish brown (10YR 5/4) (5-5.5 ft) to dark reddish brown (5YR 3/4)......

Sand, fine to coarse, subangular to angular, soft, dark-reddish-

brown $(5 Y R 3 / 4)$

Sand, very fine, silty, clayey, grayish-orange-pink (5YR 6/2)

Sand, very fine to fine, silty; grayish orange pink (5YR 6/2)

with very pale orange (10YR 8/2) mottles...

Sand, fine to medium, silty, soft, subangular to angular;

yellowish orange (10YR 7/6) with a reddish-orange

$(10 R 5 / 6)$ streak at $14 \mathrm{ft}$.

Sand, medium to coarse, silty, soft, subangular to angular,

dark-yellowish-orange (10YR 6/6)

Silt, clayey, sandy (very fine), medium-greenish-gray (5GY 5/1)

\section{UNCONFORMITY}

\section{Tar Heel Formation}

Sand, fine to medium; greenish black (5GY 2/1) grading down to medium greenish gray ( $5 G Y 5 / 1)$

Sand, fine to very coarse, poorly sorted, very clayey and silty, stiff, dense; pinkish gray (5YR 7/1) grading down through medium gray $(N 5)(27-29 \mathrm{ft})$ to light bluish gray (5B 7/1) and

bluish gray ( $5 B 6 / 1)$; interval includes three complete fining-upward

cycles, each about $2 \mathrm{ft}$ thick and grading at base from

medium to very coarse and granular with subrounded granules

upward to fine at top; coarser fractions feldspathic, finer

fractions kaolinitic

\section{Bottomed in Tar Heel Formation}




\section{Bonnetsville Quadrangle}

BO-1-05: $1.90 \mathrm{mi}$ west of eastern quadrangle border, $4.63 \mathrm{mi}$ north of southern quadrangle border, on southeastern rim of small bay $0.35 \mathrm{mi}$ southwest of intersection of North Carolina State Roads 1234 and 1235 in east-central 1/9th of map area (latitude $34.9422^{\circ} \mathrm{N}$., longitude $78.4083^{\circ} \mathrm{W}$.). Surface elevation $152 \mathrm{ft}$.

\section{LITHOLOGY}

DEPTH, IN FEET

\section{Dune sand}

Sand, fine, slightly silty, soft; yellowish brown (10YR 5/2)

grading down to pale grayish orange (10YR $8 / 4)$

\section{Varina Grove unit}

Sand, very fine to medium, silty, clayey; much stiffer and denser than unit above; scattered coarse grains and granules toward base; dark yellowish orange (10YR 6/6) grading down through light brown ( $5 R 5 / 6)$ to reddish brown $(10 R 5 / 6)$ with yellowish-gray ( $5 Y 7 / 2)$ mottles

Sand, fine to coarse, silty, dusky-yellowish-orange (10YR 5/6);

lower contact somewhat gradational $11-18$

Sand; medium to coarse grading down to coarse to very coarse; very pale orange $(10 Y R$ 8/2) grading down to orange pink (10R 7/4); sharp contact with unit below

\section{UNCONFORMITY}

\section{Chowan River Formation, Coharie Member}

Silt, clayey, sandy (very fine), stiff and dense; light orange

(10YR 7/2) with orange-pink (10R 7/4) mottles

Sand; very fine to fine grading rapidly downward to medium to coarse; light orange (10YR 7/2); about 1 percent fine, dark heavy minerals; thixotropic and soft

\section{Tar Heel Formation}

Silt, clayey, sandy (very fine), stiff; yellowish orange (10YR 7/6) with pale-yellowish-brown (10YR 6/2) streaks; weathered. 
Silt, clayey, sandy (very fine), stiff, dusky-greenish-gray

(5GY 3/1); sparse lignite; thin, very fine sand-filled

burrows

29.5-31

Base of dune sand:

Base of Varina Grove unit:

Base of Chowan River Formation, Coharie Member:

$+151 \mathrm{ft}$ above sea level

$+127 \mathrm{ft}$ above sea level

$+124.5 \mathrm{ft}$ above sea level

Bottomed in Tar Heel Formation 
BO-2-05: $3.10 \mathrm{mi}$ west of eastern quadrangle border, $6.98 \mathrm{mi}$ north of southern quadrangle border, on western side of North Carolina State Road 1303, 100 yards (yd) south of abandoned home, 0.8 mi southwest of Concord in northcentral 1/9th of map area (latitude $34.9765^{\circ} \mathrm{N}$., longitude $78.4293^{\circ} \mathrm{W}$.). Surface elevation $167 \mathrm{ft}$.

\section{LITHOLOGY}

DEPTH, IN FEET

\section{Dune sand}

Sand, fine, slightly silty, soft; yellowish brown (10YR 5/2)

grading down to light yellowish brown (10YR 6/4) ..... $0-1$

Sand, fine to medium, silty, stiff; dark yellowish orange

(10YR 6/6) grading down through light brown (5YR 5/6) to

light yellowish brown (10YR 6/4)

Sand, fine to medium, silty, thixotropic, reddish-orange (10YR 5/6).

\section{Varina Grove unit}

Sand, very fine, clayey and silty, stiff and dense; grayish red

( $5 R 4 / 2)$ grading down through medium brownish gray (5YR 5/1)

to yellowish gray (5Y 8/1) in basal foot

Sand; fine grading down through fine to medium and medium to coarse

to medium to very coarse and granular; silty; yellowish gray

(5Y 8/1) grading down through pale grayish orange (10YR 8/4)

(27-34 ft) and medium yellowish brown (10YR 5/4) (34-36 ft) to

dark yellowish orange (10YR 6/6); clayballs containing lignite lumps

in basal $3 \mathrm{ft}$.

\section{UNCONFORMITY}

\section{Tar Heel Formation}

Silt, very clayey, sandy (very fine), micaceous, lignitic, duskygreenish-gray (5GY 3/1). $37-41$

Base of dune sand:

Base of Varina Grove unit:

\section{Bottomed in Tar Heel Formation}

$+155 \mathrm{ft}$ above sea level

$+130 \mathrm{ft}$ above sea level 
BO-3-05: $5.57 \mathrm{mi}$ west of eastern quadrangle border, $3.47 \mathrm{mi}$ north of southern quadrangle border, on northern side of North Carolina State Road 1240, 0.25 mi east of Andrews Chapel in west-central 1/9th of map area (latitude $34.9254^{\circ} \mathrm{N}$., longitude $78.4726^{\circ} \mathrm{W}$.). Surface elevation $115 \mathrm{ft}$.

\section{LITHOLOGY}

DEPTH, IN FEET

\section{Dune sand}

Sand, fine, silty, soft; yellowish brown (10YR 5/2) grading down to grayish yellow (5Y 7/4).

\section{Waccamaw Formation, Bahramsville unit}

Sand, very fine to fine, silty and clayey; denser than unit above; dark yellowish orange (10YR 6/6) grading down to dark yellowish orange (10YR 6/6) with light-gray (N 7) and light-brown (5YR 5/6) mottles in basal $2 \mathrm{ft}$.

Sand, coarse to very coarse, dark-yellowish-orange (10YR 6/6); subangular to subrounded quartz pebbles up to $2 \mathrm{~cm}$ in diameter

Sand, fine to medium, silty, thixotropic, pale-yellowish-orange (10YR 8/6) $8-11$

Sand; fine to medium grading down to medium to very coarse; pale yellow (5Y 8/6); rare, scattered quartz pebbles.....

Gravel, quartz; angular to subrounded pebbles up to $2 \mathrm{~cm}$ in diameter; yellowish orange (10YR 7/6)

\section{Tar Heel Formation}

Sand, very fine, silty and clayey, micaceous, lignitic, olive-brown (5Y 3/4)

Silt, very clayey, dense and stiff, lignitic, micaceous, duskygreenish-gray (5GY 3/1); iron-oxide tubes (root ghosts?).

Base of dune sand:

Base of Waccamaw Formation, Bahramsville unit:

\section{Bottomed in Tar Heel Formation}


BO-4-05: $3.29 \mathrm{mi}$ west of eastern quadrangle border, $2.29 \mathrm{mi}$ north of southern quadrangle border, on eastern side of North Carolina State Road 1217 and southern side of cemetery, $0.6 \mathrm{mi}$ north of intersection with North Carolina State Road 1214 in south-central 1/9th of map area (latitude $34.9085^{\circ} \mathrm{N}$., longitude $78.4325^{\circ} \mathrm{W}$.). Surface elevation $140 \mathrm{ft}$.

\section{LITHOLOGY}

DEPTH, IN FEET

\section{Waccamaw Formation, Bahramsville unit}

Sand, very fine to fine, grayish-orange (10YR 6/4)

Sand, very fine to fine, clayey and silty, dense and tough; pale brown (5YR 6/6) with medium-brown (5YR 4/6), medium-red ( $5 R$ 4/6), and yellowish-gray ( $5 Y$ 8/1) mottles

Sand; fine to medium grading down to fine to coarse;

silty; dark orange (10YR 6/8).

Sand, medium to very coarse, angular to subangular, silty, medium-orange-pink (10R 7/4); abundant subrounded quartz pebbles up to $3 \mathrm{~cm}$ in diameter at base.

\section{Varina Grove unit}

Sand, fine, slightly silty, thixotropic, pinkish-gray (5YR 8/1)

Sand; fine to medium grading down to medium to coarse;

subangular to subrounded; medium reddish orange (10R 6/6)

\section{UNCONFORMITY}

\section{Tar Heel Formation}

Silt, sandy (very fine), clayey, weathered; yellowish orange (10YR 7/6) with yellowish-gray (5Y 7/1) mottles.

Sand, very fine, clayey and silty, micaceous, lignitic, duskygreenish-gray (5GY 3/1)

Base of Waccamaw Formation, Bahramsville unit: Base of Varina Grove unit:

Bottomed in Tar Heel Formation
$+117 \mathrm{ft}$ above sea level

$+111 \mathrm{ft}$ above sea level 
BO-5-08: 6.36 mi west of eastern quadrangle border, on western side of North Carolina State Road 1215 at entrance to private road, $0.65 \mathrm{mi}$ southwest of Mintz in southwestern 1/9th of map area (latitude $34.8889^{\circ} \mathrm{N}$., longitude $78.4863^{\circ} \mathrm{W}$.). Surface elevation $142 \mathrm{ft}$.

\section{LITHOLOGY}

DEPTH, IN FEET

\section{Dune sand}

Sand, fine to medium, clean, soft, humic; dark yellowish brown (10YR 3/2) grading down through light yellowish brown (10YR 6/4) (1-3 ft) to dark yellowish orange (10YR 6/6)

Sand, fine to medium, silty and slightly clayey; stiffer than interval above; pale brown (5YR 5/2) grading down to very pale brown $(5 Y R 6 / 2)$.....

Sand, fine to medium, silty, very humic, dusky-brown (5YR 2/2)

Sand, fine to medium, silty, soft; dark yellowish brown (10YR 4/2)

grading down to yellowish orange (10YR 7/4) at about $17 \mathrm{ft}$

\section{UNCONFORMITY}

\section{Waccamaw Formation, Bahramsville unit}

Silt, clayey, stiff, sticky, weathered; pale yellowish brown (10YR 6/2) with light brown (5YR 5/6) streaks; lower contact somewhat gradational

Silt, clayey, sandy (very fine), finely micaceous; medium olive gray (5Y 5/1) grading down to pale olive gray (5Y 7/1).

\section{Bottomed in Waccamaw Formation, Bahramsville unit}




\section{Cedar Creek Quadrangle}

CC-1-07: $1.70 \mathrm{mi}$ west of eastern quadrangle border, $8.09 \mathrm{mi}$ north of southern quadrangle border, $200 \mathrm{ft}$ east of North Carolina State Road 2010, 0.03 mi south of intersection of North Carolina State Roads 2010 and 2011 in northeastern 1/9th of map area (latitude $34.9925^{\circ} \mathrm{N}$., longitude $78.7795^{\circ} \mathrm{W}$.). Surface elevation about $142 \mathrm{ft}$.

\section{LITHOLOGY}

DEPTH, IN FEET

Disturbed ground, mottled and swirled sand with quartz

pebbles at base

\section{UNCONFORMITY}

\section{Dune sand}

Sand, fine to medium; increasingly more silty and carbonaceous downward; very pale orange (10YR 8/2) grading downward to pale brown (5YR 5/2)

Peat, dusky-brown (5YR 2/2) .

Sand, fine to medium, feldspathic, humic, thixotropic;

dark reddish brown (5YR 3/4) grading down to light

yellowish brown (10YR 6/4)

Peat, dusky-brown (5YR 2/2)* $11-12$

Sand, humic, dominantly fine with medium fraction, feldspathic, humic, dark-brown (5YR 2/4).

\section{UNCONFORMITY}

\section{Waccamaw Formation, Bahramsville unit}

Sand, fine, silty and slightly clayey, dark-gray (N 3);

much denser than unit above

Silt, clayey; greasy texture; medium yellowish gray (5Y 7/1);

lower contact gradational.

Silt, clayey, sandy (very fine grading down to very fine to fine), kaolinitic, very pale bluish green $(5 B G 8 / 2)$

Sand, fine to coarse, very clayey and silty, dense and sticky; greenish gray (5G 6/1) with light-gray $(N 7)$ mottles; kaolin streaks from weathered feldspar grains

Sand, medium to very coarse, poorly sorted, soft, silty; quartz pebbles toward base; pebbles subangular and up to $4 \mathrm{~cm}$ in diameter; rare clayballs; light olive gray (5Y 6/1) grading down to medium gray ( $N 5)$ 


\section{Chowan River Formation, Coharie Member(?)}

Sand, fine to medium; dark gray $(N 3)$ grading down to medium brownish gray (5YR 5/1); clasts of clayey sand with carbonized wood and fragments of aragonitic shells

\section{UNCONFORMITY}

\section{Tar Heel Formation}

Silt, very clayey, dense, medium-dark-gray $(N 4)$;

clasts of brown to black, lignitic wood

Base of dune sand:

Base of Waccamaw Formation, Bahramsville unit:

Base of Chowan River Formation, Coharie Member(?):

+127 feet elevation

+101 feet elevation

+91 feet elevation

\section{Bottomed in Tar Heel Formation}

*Wood fragment at base of peat yielded a radiocarbon age greater than 51,800 B.P.

(John P. McGeehin, USGS, written commun., 2008). 
CC-2-07: $1.72 \mathrm{mi}$ west of eastern quadrangle border, $1.90 \mathrm{mi}$ north of southern quadrangle border, on eastern side of dirt road near northern side of cemetery, $0.83 \mathrm{mi}$ northeast of intersection of North Carolina State Roads 2228 and 2023 in southeastern $1 / 9$ th of map area (latitude $34.9027^{\circ} \mathrm{N}$., longitude $78.7799^{\circ} \mathrm{W}$.). Surface elevation about $88 \mathrm{ft}$.

\section{LITHOLOGY}

DEPTH, IN FEET

\section{Dune sand}

Sand, fine to medium, soft; medium grayish brown

(5YR 4/2) grading down to very pale yellowish

brown $(10 Y R$ 7/2)......

Peat, sandy, dark-brown (5YR 2/4)

Sand, fine to medium, soft; grayish orange pink (5YR 7/2)

grading to dark yellowish orange (10YR 6/6) at $4 \mathrm{ft}$.....

UNCONFORMITY

\section{Charles City Formation}

Silt, clayey; much stiffer than unit above; pale yellowish

brown $(10 Y R 6 / 2)$ grading down to yellowish gray

$(5 Y 7.5 / 1)$.

Sand, very fine to fine, silty, slightly clayey, medium

yellowish gray ( $5 Y 6 / 2)$; lower contact gradational.

Sand; fine to medium grading down to medium to coarse;

silty; feldspathic; sparse subangular quartz granules;

medium yellowish gray (5Y 6/2); lower contact

somewhat gradational

Sand; fine grading down to fine to medium; pale

yellowish gray (5Y 8/2); $1-2$ percent very fine,

dark, heavy minerals; thixotropic.

Sand, medium to coarse, feldspathic, garnetiferous, medium-gray ( $N 5$ ); subrounded to rounded quartz granules and sparse shell and wood fragments; rounded quartz pebbles up to $1 \mathrm{~cm}$ in basal foot.

\section{Tar Heel Formation}

Silt, clayey, dense; occasional lumps of pyrite; dark olive gray (5Y 3/1) grading down to very dark gray ( $N 2.5)$.

Base of dune sand:

Base of Charles City Formation:

\section{Bottomed in Tar Heel Formation}

$+80 \mathrm{ft}$ above sea level

$+47 \mathrm{ft}$ above sea level 
CC-3-07: $6.30 \mathrm{mi}$ west of eastern quadrangle border, $6.42 \mathrm{mi}$ north of southern quadrangle border, $400 \mathrm{ft}$ east of North Carolina State Road 2212, 0.4 mi south-southeast of center of overpass across Interstate 95 in northwestern 1/9th of map area (latitude $34.9683^{\circ} \mathrm{N}$., longitude $78.8606^{\circ} \mathrm{W}$.). Surface elevation about $164 \mathrm{ft}$.

\section{LITHOLOGY}

DEPTH, IN FEET

\section{Varina Grove unit}

Sand, very fine to fine, slightly silty, soft; grayish brown (5YR 4/2) (3 in. thick) over pale grayish orange $(10 Y R$ 8/4)

Sand, very fine to fine, slightly silty; dark yellowish orange

(10YR 6/6) with dark-yellowish-gray (5Y 6/2) mottles $1-8$

Sand, very fine to fine, slightly silty; light brown (5YR 5/6) grading down to yellowish orange (10YR 7/6).

Sand, fine to medium, subangular, slightly silty; dark

yellowish orange $(10 Y R 5 / 6)$ grading down to pale grayish orange $(10 Y R$ 8/4)

\section{UNCONFORMITY}

\section{Tar Heel Formation}

Silt, clayey, sandy (very fine), very micaceous, yellowish-gray (5Y 8/1).

Sand; dominantly fine with some medium; silty; very micaceous; dark yellowish orange $(10 Y R 6 / 6)$ with medium-reddish-brown (10R 4/6) mottles around plinthite nodules.

Clay, silty, weathered; dark yellowish orange (10YR 6/6) with medium-yellowish-brown (10YR 5/4) streaks.

Clay, silty, dense, stiff, dark-gray ( $N$ 3); rare blebs of black, lignitic wood

Base of Varina Grove unit:

$+147 \mathrm{ft}$ above sea level

\section{Bottomed in Tar Heel Formation}


CC-4-07: $3.60 \mathrm{mi}$ west of eastern quadrangle border, $3.90 \mathrm{mi}$ north of southern quadrangle border, on western side of North Carolina State Road 2233, 0.15 mi south of intersection with southern end of North Carolina State Road 2224 in central 1/9th of map area (latitude $34.9318^{\circ} \mathrm{N}$., longitude $78.8131^{\circ} \mathrm{W}$.). Surface elevation about $80 \mathrm{ft}$.

\section{LITHOLOGY}

DEPTH, IN FEET

\section{Dune sand}

Sand, fine to medium, soft, pale-grayish-orange (10YR 8/4)

\section{UNCONFORMITY}

\section{Older alluvium}

Sand, medium to very coarse, poorly sorted, silty and slightly clayey, light-brown (5YR 5/6)...

Sand, medium to very coarse, poorly sorted, slightly silty, very pale grayish orange (10YR 9/4).

Sand, medium to very coarse, poorly sorted, very pale grayish orange (10YR 9/4); abundant pebbles up to $5 \mathrm{~cm}$ in diameter

Gravel, composed of subrounded to rounded quartz pebbles up to $5 \mathrm{~cm}$ in diameter; yellowish gray (5Y 8/1) grading down to medium dark gray $(N 4)$

\section{UNCONFORMITY}

\section{Cape Fear Formation}

Sand, fine to medium, angular to subangular; clay matrix mostly kaolin; dense; light gray ( $N$ 7.5) grading down to medium light gray ( $N$ 6)

Base of dune sand:

Base of older alluvium:

\section{Bottomed in Cape Fear Formation}

$+77 \mathrm{ft}$ above sea level $+67 \mathrm{ft}$ above sea level 
CC-5-07: $5.88 \mathrm{mi}$ west of eastern quadrangle border, $1.70 \mathrm{mi}$ north of southern quadrangle border, $100 \mathrm{ft}$ south of North Carolina State Road 2261, $300 \mathrm{ft}$ west of intersection of North Carolina State Roads 87 and 2261 in southwestern 1/9th of map area (latitude $34.8997^{\circ} \mathrm{N}$., longitude $78.8530^{\circ} \mathrm{W}$.). Surface elevation about $159 \mathrm{ft}$.

\section{LITHOLOGY}

DEPTH, IN FEET

\section{Varina Grove unit}

Sand; dominantly very fine but up to fine; silty; clayey in basal 6 in.; pale yellowish brown (10YR 6/2) grading

down through pale yellowish gray (5Y 8/2) (0.5-1.5 ft) to

light brown (5YR 5/6).

Sand, very fine, silty, slightly clayey; light brown (5YR 5/6)

grading down to dark yellowish orange (10YR 6/6) at $4 \mathrm{ft.}$.

Sand, very fine to fine grading down to fine to medium; clean;

pale yellowish orange $(10 Y R$ 8/8) grading down through yellowish

gray $(5 Y$ 8/1) $(10-12 \mathrm{ft})$ to light orange pink (10R 8/4)...

Sand, fine to coarse, poorly sorted, slightly silty and clayey,

grayish-orange (10YR 7/4); subrounded to rounded

quartz granules.

Sand, fine to medium, very silty and clayey; pale olive

gray ( $5 Y 7 / 1)$ with medium-red ( $5 R$ 5/4) mottles; interbedded

with very fine to fine, silty, grayish-orange(10YR 7/4) sand.

Sand, fine to medium, silty, medium-red ( $5 R 5 / 4)$.

\section{Tar Heel Formation}

Clay, silty, dense, stiff, sticky, medium-dark-gray ( $N 4)$;

occasional lenses of clean, angular, very fine quartz

sand and pyrite lumps

21-31

Base of Varina Grove unit:

$+138 \mathrm{ft}$ above sea level

Bottomed in Tar Heel Formation 


\section{Clinton South Quadrangle}

CS-1-05: $0.80 \mathrm{mi}$ west of eastern quadrangle border, $7.64 \mathrm{mi}$ north of southern quadrangle border, by abandoned house on farm road 0.9 mi northeast of Bethany Church in northeastern 1/9th of map area (latitude $34.9849^{\circ} \mathrm{N}$., longitude $78.2639^{\circ} \mathrm{W}$.). Surface elevation $150 \mathrm{ft}$.

\section{LITHOLOGY}

DEPTH IN FEET

\section{Dune sand}

Sand, very fine to fine with sparse medium to coarse grains, clean; yellowish orange $(10 Y R$ 7/6) grading down to light yellowish brown (10YR 6/4)

\section{Varina Grove unit}

Sand, very fine, clayey and silty, dark reddish brown

(10R 3/6) with brownish-gray (5YR 4/1) mottles grading down to medium brownish gray (5YR 5/1) .

Sand; fine grading down to fine to medium; medium

brownish gray $(5 Y R$ 5/1) with very light gray $(N 8)$ mottles.

Silt, very clayey, sticky and dense, light-gray $(N 7)$......

Silt, sandy (very fine), slightly clayey; scattered grains of

fine to medium, subangular quartz sand; medium

dark gray $(N 4)$; grades rapidly to very fine to coarse, poorly sorted, silty clay; dense clasts of lignitized wood and a discoidal quartz pebble $2.5 \mathrm{~cm}$ in maximum diameter near base.

\section{UNCONFORMITY}

\section{Tar Heel Formation}

Silt, very clayey, finely micaceous, dense and sticky, darkgreenish-gray (5GY 3/1)

Base of dune sand:

Base of Varina Grove unit:

\section{Bottomed in Tar Heel Formation}

$+147 \mathrm{ft}$ above sea level

$+133 \mathrm{ft}$ above sea level 
CS-2-05: $1.92 \mathrm{mi}$ west of eastern quadrangle border, $2.25 \mathrm{mi}$ north of southern quadrangle border, by abandoned house southeast of North Carolina State Road 1150, 0.3 mi northwest of intersection with North Carolina State Road 1147 in southeastern $1 / 9$ th of map area (latitude $34.9077^{\circ} \mathrm{N}$., longitude $78.2831^{\circ} \mathrm{W}$.). Surface elevation $143 \mathrm{ft}$.

\section{LITHOLOGY}

DEPTH, IN FEET

\section{Varina Grove unit}

Sand, very fine to fine, clean, light-yellowish-brown

$(10 Y R$ 6/4) $0-1$

Sand, very fine, silty and clayey, stiff and dense, massive;

light brown (5YR 6/6) grading down to medium reddish

brown (10R 4/6); plinthite nodules up to $0.5 \mathrm{~cm}$ in diameter

Sand; very fine to fine grading down to fine; less silty and

clayey downward; medium reddish brown $(10 R 4 / 6)$

grading down to yellowish orange (10YR 7/6).

Sand, fine, slightly silty; much softer than interval above;

yellowish gray (5Y 8/1); lower contact somewhat gradational

Sand, medium to coarse; contains sparse subrounded

Quartz granules; dark yellowish orange (10YR 5/6) .....

\section{UNCONFORMITY}

\section{Tar Heel Formation}

Sand, medium to coarse, coarsely micaceous, dense, yellowish-orange (10YR 7/6); fine, silty, lignitic, light olive gray ( $5 Y 5 / 2)$ to pale grayish orange (10YR 8/4)

and medium brown (5YR 4/6) sand lenses ......

Base of Varina Grove unit:

$+115 \mathrm{ft}$ above sea level

Bottomed in Tar Heel Formation 
CS-3-05: $6.13 \mathrm{mi}$ west of eastern quadrangle border, $7.18 \mathrm{mi}$ north of southern quadrangle border, on eastern side of North Carolina State Road 1262, 0.5 mi north of intersection with North Carolina State Road 1228 in northwestern 1/9th of map area (latitude $34.9790^{\circ} \mathrm{N}$., longitude $78.3575^{\circ} \mathrm{W}$.). Surface elevation $137 \mathrm{ft}$.

\section{LITHOLOGY}

DEPTH, IN FEET

\section{Varina Grove unit}

Sand, fine to medium; scattered coarse grains; silty; dark yellowish orange (10YR 6/6)

Sand, medium to very coarse, poorly sorted, slightly silty, dark-yellowish-orange (10YR 6/6); subrounded to rounded quartz pebbles up to $2 \mathrm{~cm}$ in diameter near base

\section{UNCONFORMITY}

\section{Tar Heel Formation}

Sand, very fine to fine, silty, dense, medium-brown (5YR 4/6)

Sand; very fine to fine, scattered grains up to very

coarse; very micaceous (coarse mica plates); silty; dark

yellowish orange (10YR 6/6).

Sand, fine to medium, subangular; clayey matrix;

pale olive gray (5Y 6/2)

Silt, clayey, sandy (very fine), dense, finely micaceous, very dark greenish gray (5GY 3/1)

Base of Varina Grove unit:

$+132 \mathrm{ft}$ above sea level

\section{Bottomed in Tar Heel Formation}


CS-4-05: $4.23 \mathrm{mi}$ west of eastern quadrangle border, $5.15 \mathrm{mi}$ north of southern quadrangle border, at home site on northern side of North Carolina State Road 1146, $0.3 \mathrm{mi}$ west of intersection with U.S. Highway 701 in central 1/9th of map area (latitude $34.9496^{\circ} \mathrm{N}$., longitude $78.3241^{\circ} \mathrm{W}$.). Surface elevation $162 \mathrm{ft}$.

\section{LITHOLOGY}

DEPTH, IN FEET

\section{Dune sand}

Sand, very fine to fine, silty; dark yellowish brown

(10YR 4/2) grading down to medium yellowish

orange (10YR 7/6)

Sand; coarsens slightly downward to dominantly

fine; silty; pale reddish brown (10R 5/6) with

yellowish-gray (5Y 7/1) streaks

Sand, fine, slightly silty, pale-grayish-orange

(10YR 8/4); white kaolin powder visible upon drying.

\section{UNCONFORMITY}

\section{Varina Grove unit}

Sand, fine to medium, slightly silty, thixotropic; very

fine, dark, heavy minerals; pale yellow (5Y 8/6)

grading down to pale yellowish gray ( $5 Y 8 / 2)$

Sand, fine, silty and clayey, pale yellowish gray

(5Y 8/2) with reddish-brown (10R 5/6) mottles

Sand, fine to coarse, poorly sorted, subangular, yellowishorange (10YR 7/6)

Sand, medium to very coarse, poorly sorted, feldspathic; sparse fine, dark, heavy minerals; angular to subrounded; clean; yellowish gray (5Y 8/1) grading down to yellowish orange (10YR 7/6).

\section{UNCONFORMITY}

\section{Tar Heel Formation}

Sand, fine to coarse, poorly sorted, silty, lignitic;

olive gray (5Y 4/2) with olive-black (5Y 2/1) clayballs

Sand, fine, silty and clayey, micaceous, olive-black (5Y 2/1).....

Sand, fine to coarse, poorly sorted, silty, lignitic, olive-gray (5Y 4/2).

Base of dune sand:

Base of Varina Grove unit:

\section{Bottomed in Tar Heel Formation}

$+152 \mathrm{ft}$ above sea level

$+133 \mathrm{ft}$ above sea level 
CS-5-05: $6.58 \mathrm{mi}$ west of eastern quadrangle border, $2.74 \mathrm{mi}$ north of southern quadrangle border, on old road (not on map) 1.35 mi southwest by west of Tyndall Grove Church in southwestern $1 / 9$ th of map area (latitude $34.9107^{\circ} \mathrm{N}$., longitude $78.3651^{\circ} \mathrm{W}$.). Surface elevation $140 \mathrm{ft}$.

\section{LITHOLOGY}

DEPTH, IN FEET

\section{Varina Grove unit}

Sand, fine to medium, subangular to subrounded, slightly

silty, light-yellowish-brown (10YR 6/4).....

Sand, medium to coarse, silty; light yellowish brown

(10YR 6/4) grading down to medium brown (5YR 4/6);

granules and small, subangular to subrounded

quartz pebbles up to $0.7 \mathrm{~cm}$ in diameter.

Sand, medium to coarse, silty; pale brown ( $5 Y R$ 6/2)

grading down to dark yellowish orange (10YR 6/6);

quartz-pebble gravel at base with subrounded pebbles

up to $1.1 \mathrm{~cm}$ in diameter.

Sand; fine to coarse, dominantly medium; angular to

subangular; pale grayish orange (10YR 8/4)

Sand; fine to coarse, dominantly medium; angular to

subangular; silty; kaolinitic; coarsely micaceous;

pale yellowish brown (10YR 5/6).

Sand, fine to coarse, angular to subangular, poorly sorted,

very pale orange (10YR $8 / 2)$; quartz granule to pebble

bed at base; subangular to subrounded pebbles

up to $0.7 \mathrm{~cm}$ in diameter.

\section{UNCONFORMITY}

\section{Tar Heel Formation}

Sand, fine to medium, very silty and kaolinitic, very micaceous; yellowish gray ( $5 Y$ 8/1) grading down to pale yellowish orange (10YR 8/6)

Base of Varina Grove unit:

$+117 \mathrm{ft}$ above sea level

Bottomed in Tar Heel Formation 
CS-6-08: $6.11 \mathrm{mi}$ west of eastern quadrangle border, $2.73 \mathrm{mi}$ north of southern quadrangle border, on northern side of North Carolina State Road 1221, 0.48 mi east of intersection with North Carolina State Road 1219 in southwestern 1/9th of map area (latitude $34.9105^{\circ} \mathrm{N}$., longitude $78.3573^{\circ} \mathrm{W}$.). Surface elevation $152 \mathrm{ft}$.

\section{LITHOLOGY}

DEPTH, IN FEET

\section{Dune sand}

Sand, fine to medium, slightly silty, soft; yellowish orange

(10YR 7/6) grading down to dark yellowish orange (10YR 6/6) $0-4$

\section{UNCONFORMITY}

\section{Varina Grove unit}

Sand; very fine to fine grading down to fine to medium;

silty; slightly clayey; stiff; dark yellowish orange

(10YR 6/6) with darker yellowish-orange (10YR 5/6) streaks

Sand, very fine to fine, clayey, silty; yellowish gray ( $5 Y 7 / 2)$

grading down to grayish orange pink (5YR 7/2) at $11 \mathrm{ft}$

Sand, fine to medium, silty; much softer than interval above; light

orange (10YR 7/8); contains one clay-rich, pale-grayish-orange pink (5YR 8/2)

sand rip-up clast; lower contact somewhat gradational

Sand; fine to coarse grading down to medium to very coarse;

poorly sorted; silty; soft; yellowish gray (5Y 8/1); abundant subrounded

to rounded quartz granules and pebbles up to $1 \mathrm{~cm}$ in diameter in basal foot

\section{UNCONFORMITY}

\section{Tar Heel Formation}

Sand, very fine to fine, clayey and silty; dark yellowish

orange (10YR 6/6) with darker yellowish-orange (10YR 5/6)

streaks; dense, rounded clasts of lignitic wood up to $3 \mathrm{~cm}$ in diameter

Clay, silty, greasy, very dense; pale yellowish brown

(10YR 6/2) with dark-yellowish-orange (10YR 6/6)

and yellowish-brown (10YR 5/2) streaks

Base of dune sand:

Base of Varina Grove unit:

\section{Bottomed in Tar Heel Formation}

$+148 \mathrm{ft}$ above sea level

$+130 \mathrm{ft}$ above sea level 
CS-7-08: $2.15 \mathrm{mi}$ west of eastern quadrangle border, $2.88 \mathrm{mi}$ north of southern quadrangle border, at entrance to dirt road on eastern side of North Carolina State Road 1150, 1.05 mi north-northwest of intersection with North Carolina State Road 1147 on boundary between east-central and southeastern 1/9th of map area (latitude $34.9167^{\circ} \mathrm{N}$., longitude $78.2873^{\circ} \mathrm{W}$.). Surface elevation $156 \mathrm{ft}$.

\section{LITHOLOGY}

DEPTH, IN FEET

\section{Dune sand}

Sand, fine, well-sorted, silty, grayish-yellow (5Y 7/4)

Sand; dominantly fine with some medium grains; slightly

silty; soft; pale yellowish gray ( $5 Y$ 8/2) with dark-yellowish-orange

(10YR 6/6) streaks grading down through pale brown and

humic (5YR 6/2) (3-4 ft) to pale pinkish gray (5YR 9/1)

Sand; dominantly fine with some medium grains; slightly

silty; soft; dark yellowish orange (10YR 6/6) grading

down to yellowish gray (5Y 8/1).

Sand, very fine to fine, silty and slightly clayey, pale-brown

(5YR 5/2); stiffer than interval above; 1 -cm-thick layer of

carbonaceous material at top.....

Sand, very fine to fine, silty and slightly clayey, pale-

yellowish-brown (10YR 7/2); lower contact gradational.

Sand, fine, silty, clayey, yellowish-gray (5Y 8/1);

clay stringers; lower contact abrupt

Peat, woody, dusky-brown (5YR 2/2)*

Clay, silty, sandy (very fine grading down to very

fine to fine), medium-dark-gray ( $N 4)$.....

\section{UNCONFORMITY}

\section{Varina Grove unit}

Sand, very fine to fine, silty and clayey; dark yellowish orange (10YR 6/6) with pale-orange (10YR 7/2) mottles

Sand, fine to medium, slightly silty, yellowish-gray $(5 Y$ 8/1) ..................................................................... 25-26

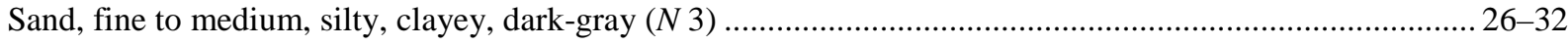

Sand; dominantly fine with rare, scattered, medium to very

coarse grains; silty; clayey; medium-olive-brown (5Y 4/6)

Sand, fine, silty, clayey, olive-gray ( $5 Y 3 / 2)$; scattered quartz granules and pebbles at base up to $0.5 \mathrm{~cm}$ in diameter 


\section{Tar Heel Formation}

Clay, micaceous, lignitic, very stiff and dense, dark-greenishgray $(5 G Y 4 / 1) \ldots$

Base of dune sand:

Base of Varina Grove unit:

\section{Bottomed in Tar Heel Formation}

*Wood fragment in peat yielded a radiocarbon age greater than 51,800 B.P. (John P. McGeehin, USGS, written commun., 2008).
$+131.5 \mathrm{ft}$ above sea level $+121 \mathrm{ft}$ above sea level 
CS-8-08: $4.63 \mathrm{mi}$ west of eastern quadrangle border, $2.28 \mathrm{mi}$ north of southern quadrangle border, on eastern side of U.S. Highway 701, 1.1 mi south of intersection with North Carolina State Road 1222 (west side) and 1149 (east side) at Butlers Crossroads in south-central 1/9th of map area (latitude $34.9080^{\circ} \mathrm{N}$., longitude $78.3310^{\circ} \mathrm{W}$.). Surface elevation $166 \mathrm{ft}$.

\section{LITHOLOGY}

DEPTH, IN FEET

\section{Dune sand}

Sand, fine, soft, slightly silty and clayey toward base; yellowish brown (10YR 5/2) grading down through pale grayish orange (10YR 8/4) to dark yellowish orange (10YR 6/6).

Sand; dominantly fine but with some medium grains;

clean to slightly silty; pale grayish yellow (5Y 9/4)

with dark-yellowish-orange (10YR 6/6)

Sand, fine, clean, thixotropic; intermingled pale orange (10YR 8/2)

and grayish yellow (5Y 7/4) .....

Sand, fine, silty, slightly clayey, soft; very pale brown

(5YR 6/2) grading down to grayish brown (5YR 3/2).....

Sand, fine, slightly silty, soft, pale-brown (5YR 5/2)

\section{Varina Grove unit}

Sand; dominantly fine but with some medium grains; silty, clayey, pale-grayish-orange-pink (10YR 8/2);

much stiffer and denser than unit above; lower contact gradational

Sand; dominantly fine but with some medium grains;

slightly silty; slightly clayey; pale grayish orange

(10YR 8/4) grading down to pale yellowish gray (5Y 9/1);

lower contact gradational

Sand; fine to coarse with minor fraction of very coarse;

subangular to angular; poorly sorted; pale yellowish gray

$(5 Y 9 / 1)$

\section{Base of dune sand:}

\section{$+153 \mathrm{ft}$ above sea level}

\section{Bottomed in Varina Grove unit}


CS-9-08: $1.70 \mathrm{mi}$ west of eastern quadrangle border, $5.51 \mathrm{mi}$ north of southern quadrangle border, on northern side of North Carolina State Road 1935, 0.78 mi northeast of intersection with U.S. Highway 421 in east-central 1/9th of map area (latitude $34.9551^{\circ} \mathrm{N}$., longitude $78.2793^{\circ} \mathrm{W}$.). Surface elevation $160 \mathrm{ft}$.

\section{LITHOLOGY}

DEPTH, IN FEET

\section{Dune sand}

Sand, fine, slightly silty; upper half humic and yellowish

brown (5YR 5/2), lower half light yellowish brown (10YR 6/4).

Sand; dominantly fine but with some medium grains; slightly

silty; dark yellowish orange (10YR 6.5/6) with medium-

brown (5YR 4/6) mottles below $3 \mathrm{ft}$......

Sand; dominantly fine but with some medium grains; soft;

very fine; dark, heavy minerals or charcoal flakes;

yellowish gray (5Y 8/1) grading down to dark yellow (5Y 6/6)

Sand, fine, silty, slightly clayey; stiffer and denser than interval above; pale yellowish brown (10YR 6/2) with medium-orange (10YR 7/8) mottles .

Sand, fine, clean; yellowish gray (5Y 8/1) grading down through

yellowish orange (10YR 7/6) (11-12 ft) to pale yellowish

gray (5Y 7/2) intermingled with dark yellow (5Y 7/4);

less than 1 percent very fine, dark, heavy minerals.

Silt, clayey, yellowish-gray (5Y 8/1); 2 in. thick

Sand, fine, clean, thixotropic; pale yellowish gray (5Y 7/2)

intermingled with dark yellow (5Y 7/4)

\section{UNCONFORMITY}

\section{Varina Grove unit}

Sand, fine to very coarse, poorly sorted, clayey, silty; very pale orange (10YR $8 / 2)$ grading down to pale orange (10YR $7 / 2)$;

subangular granules of quartz

Base of dune sand:

$+138 \mathrm{ft}$ above sea level

\section{Bottomed in Varina Grove unit}




\section{Costin Quadrangle}

CO-1-04: $5.80 \mathrm{mi}$ west of eastern quadrangle border, $4.53 \mathrm{mi}$ north of southern quadrangle border, $200 \mathrm{ft}$ south of North Carolina State Road 1216, 0.22 mi west of intersection with North Carolina State Road 11 and U.S. Highway 421 (Piney Wood) in west-central 1/9th of map area (latitude $34.5659^{\circ} \mathrm{N}$., longitude $78.1014^{\circ} \mathrm{W}$.). Surface elevation $65 \mathrm{ft}$.

\section{LITHOLOGY}

DEPTH, IN FEET

\section{Charles City Formation}

Sand, fine to medium, subangular, silty, clayey; olive brown

(5Y 6/6) grading down to dusky yellowish orange (10YR 5/6);

round quartz pebbles at base up to $1 \mathrm{~cm}$ in diameter

Silt, clayey and sandy (very fine), tough; light brown

(5YR 5/6) with yellowish-gray (5Y 7/2) mottles grading down

to yellowish gray (5Y 7/2) with light-brown (5YR 5/6) mottles

Sand medium to coarse grading down to medium to very

coarse; angular to subangular; poorly sorted; some

granules; silty; dark yellowish orange (10YR 6/6)

$11-23$

Silt, clayey, sandy (very fine), grayish-orange (10YR 7/4)

Sand, coarse to very coarse, pebbly, dark-yellowish-orange

(10YR 6/6)

\section{UNCONFORMITY}

\section{Windsor Formation}

Silt, sandy (very fine), clayey, yellowish-orange (10YR 7/6) 34-35

Silt, sandy (very fine), slightly clayey, slightly micaceous, dark-greenish-gray (5G 4/1)

\section{Bladen Formation}

Sand, fine to medium, silty, olive-gray (5Y 3/2)

39-46

Base of Charles City Formation:

+31 ft above sea level

Base of Windsor Formation:

+26 ft above sea level

\section{Bottomed in Bladen Formation}


CO-2-04: $2.96 \mathrm{mi}$ west of eastern quadrangle border, $1.84 \mathrm{mi}$ north of southern quadrangle border, on northern side of North Carolina State Road 1403 at entrance to dirt road, 1.25 mi east-southeast of Wards Corner, in south-central 1/9th of map area (latitude $34.5270^{\circ} \mathrm{N}$., longitude $78.0515^{\circ} \mathrm{W}$.). Surface elevation $47 \mathrm{ft}$.

\section{LITHOLOGY}

DEPTH, IN FEET

\section{Charles City Formation}

Sand; very fine to fine but with scattered medium to very coarse grains; silty and clayey; yellowish brown (10YR 5/2) (2 in. thick) over dark yellowish gray (5Y 6/2).....

Sand, dominantly fine to medium, poorly sorted, clayey, silty, stiff; dark yellowish orange (10YR 6/6) grading

down to pale orange (10YR 7/2)

Sand; dominantly medium to coarse but with some very coarse grains and granules; silty; yellowish gray (5Y 7/4) (6-8 ft) grading down to yellowish gray (5Y 8/1); contains quartz pebbles up to $2 \mathrm{~cm}$ in diameter

\section{UNCONFORMITY}

\section{Windsor Formation}

Sand, very fine to fine, silty, slightly clayey; pale olive (10Y 6/4) grading down through dark yellowish orange (10YR 6/6)

(17.5-18.5 ft) to dark greenish gray (5GY 4/1).

Base of Charles City Formation:

$+30 \mathrm{ft}$ above sea level

\section{Bottomed in Windsor Formation}


CO-3-04: $4.58 \mathrm{mi}$ west of eastern quadrangle border, $7.32 \mathrm{mi}$ north of southern quadrangle border, on southern side of North Carolina State Road 1209 at entrance to dirt road, 1.7 mi east-northeast of Shiloh Church, in north-central 1/9th of map area (latitude $34.6064^{\circ} \mathrm{N}$., longitude $78.0799^{\circ} \mathrm{W}$.). Surface elevation $66 \mathrm{ft}$.

\section{LITHOLOGY}

DEPTH, IN FEET

\section{Charles City Formation}

Sand, very fine, silty and clayey; dark yellowish brown

(10YR 4/2) with pale-yellowish-brown (10YR 6/2) mottles

over dusky yellow (10Y 6/4) with light-brown

(5YR 5/6) and light-olive-gray (5Y 6/1) mottles

Sand, very fine, clayey and silty; light olive gray (5Y 6/1)

with dusky-yellow (10Y 6/4) and light-brown (5YR 5/6) mottles

grading down to yellowish orange (10YR 7/6) with light-

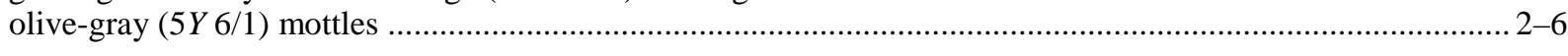

Silt, sandy (very fine), clayey, yellowish-orange (10YR 7/6)......................................................................... 6-13

Silt, clayey, light-olive-gray $(5 Y$ 6/1) ........................................................................................................ 13-15

Sand, very fine, silty, clayey; grades down to fine,

silty sand; medium olive gray $(5 Y$ 5/1) ……....................................................................................... 15-20

\section{UNCONFORMITY}

\section{Windsor Formation}

Silt, clayey, greasy, dark-greenish-gray (5G 4/1) .

Sand; fine to medium grading down to medium to coarse;

silty, medium dark gray $(N 4)$; quartz pebbles up to

$2 \mathrm{~cm}$ in diameter in basal foot

\section{UNCONFORMITY}

\section{Bladen Formation}

Sand, fine to medium, silty, dark-grayish-olive (10Y 3/2)...

Base of Charles City Formation:

Base of Windsor Formation:

$+46 \mathrm{ft}$ above sea level

$+24 \mathbf{f t}$ above sea level

\section{Bottomed in Bladen Formation}


CO-4-04: $1.13 \mathrm{mi}$ west of eastern quadrangle border, $5.11 \mathrm{mi}$ north of southern quadrangle border, on dirt road on western side of power line, $0.95 \mathrm{mi}$ north of New Hope Church, in east-central 1/9th of map area (latitude $34.5743^{\circ} \mathrm{N}$., longitude $78.0196^{\circ} \mathrm{W}$.). Surface elevation $53 \mathrm{ft}$.

\section{LITHOLOGY}

DEPTH, IN FEET

Road fill $0-1$

\section{UNCONFORMITY}

\section{Charles City Formation}

Sand, very fine, silty and clayey; dusky yellowish brown (10YR 2/2) grading rapidly down to dark yellowish gray (5Y 7/1); sand grades rapidly to dark yellowish orange (10YR 6/6) with light-brown (5YR 5/6) and dark-yellowish-gray (5Y 7/1) mottles at $3 \mathrm{ft}$

Silt, clayey; greasy texture; greenish gray (5GY 6/1) grading to olive gray $(5 Y 4 / 1)$ at $12 \mathrm{ft}$.

Sand, very fine to fine, slightly silty, thixotropic, olive-gray (5Y 4/1)

\section{Windsor Formation}

Silt, clayey, dark-greenish-gray (5G 4/1).

Sand, fine to medium, soft, dark-greenish-gray

$(5 G 4 / 1)$.

\section{Bladen Formation}

Sand, fine to medium, olive-gray ( $5 Y 3 / 2)$; much denser than unit above.

Base of Charles City Formation:
Base of Windsor Formation:

\section{Bottomed in Bladen Formation}

\section{$+14 \mathrm{ft}$ above sea level $-4 \mathrm{ft}$ below sea level}


CO-5-05: $0.26 \mathrm{mi}$ west of eastern quadrangle border, $0.37 \mathrm{mi}$ north of southern quadrangle border, on southwestern side of North Carolina State Road 1402, 0.45 mi northwest of southeastern corner of quadrangle, in southeastern 1/9th of map area (latitude $34.5055^{\circ} \mathrm{N}$., longitude $78.0041^{\circ} \mathrm{W}$.). Surface elevation $52 \mathrm{ft}$.

\section{LITHOLOGY}

DEPTH, IN FEET

\section{Chuckatuck Formation}

Sand, very fine, silty, slightly clayey; yellowish brown

(10YR 5/2) over grayish yellow (5Y 7/4).....

Sand, very fine, silty and clayey; grayish yellow (5Y 7/4)

with reddish-brown (10R 5/6) mottles grading down through

yellowish orange (10YR 7/6) with medium-gray $(N 5)$

(6-7 ft) to yellowish-gray (5Y 8/1) mottles

Sand, fine, silty; softer than interval above; reddish brown $(10 R$ 5/6)

grading down to yellowish orange (10YR 7/6) at $8.5 \mathrm{ft}$......

Sand, fine to medium, light-yellowish-brown (10YR 6/4)

Sand, medium to coarse; light yellowish brown (10YR 6/4) grading

down to yellowish orange (10YR 7/6) at $19 \mathrm{ft}$.

Sand, medium to very coarse; pale brown (5YR 6/6) grading

down through orange (10YR 7/8) to olive gray (5Y 4/2)

at $32 \mathrm{ft}$; subangular to subrounded quartz pebbles

up to $1.2 \mathrm{~cm}$ in diameter.

\section{UNCONFORMITY}

\section{Windsor Formation}

Sand, fine, well-sorted, silty, dark-greenish-gray (5GY 4/1);

thixotropic in top $10 \mathrm{ft}$; micaceous below $55 \mathrm{ft}$. 35-98

Base of Chuckatuck Formation:

$+17 \mathrm{ft}$ above sea level

\section{Bottomed in Windsor Formation}




\section{Delway Quadrangle}

DE-1-04: 3.27 mi west of eastern quadrangle border, $4.50 \mathrm{mi}$ north of southern quadrangle border, on northwestern side of North Carolina State Road 1003, 0.65 mi east-northeast of intersection with North Carolina State Road 1946, in central 1/9th of map area (latitude $34.8155^{\circ} \mathrm{N}$., longitude $78.1822^{\circ} \mathrm{W}$.). Surface elevation $118 \mathrm{ft}$.

\section{LITHOLOGY}

DEPTH, IN FEET

\section{Waccamaw Formation, Bahramsville unit}

Sand; fine with scattered medium to coarse grains;

silty, clayey; yellowish brown (10YR 5/2) grading down

through light yellowish brown (10YR 6/4) $(0.5-1 \mathrm{ft})$ to

dusky yellowish orange (10YR 5/6)

Sand, fine, silty, clayey, yellowish-orange (10YR 7/6)

Sand, fine to medium, silty, soft; yellowish orange (10YR 7/6) grading down through grayish olive (10Y 4/2)

(27-36 ft) to dark greenish gray (5GY 4/1) 14-39

\section{Tar Heel Formation}

Sand, very fine, very clayey, silty, dense; locally abundant coarse mica and lignite; dark olive gray (5Y 3/1) with grayish-green (10GY 5/2) blotches in basal foot.

\section{Bottomed in Tar Heel Formation}


DE-2-04: $1.62 \mathrm{mi}$ west of eastern quadrangle border, 7.27 mi north of southern quadrangle border, on northern side of North Carolina State Road 1118, 0.6 mi east of Duplin-Sampson County line, in northeastern 1/9th of map area (latitude $34.8554^{\circ} \mathrm{N}$., longitude $78.1534^{\circ} \mathrm{W}$.). Surface elevation $137 \mathrm{ft}$.

\section{LITHOLOGY}

DEPTH, IN FEET

\section{Waccamaw Formation, Bahramsville unit}

Sand, fine, silty, clayey; very dark yellowish brown

(10YR 3/2) over light yellowish brown (10YR 6/4).

Sand, fine, very clayey, silty; dark yellowish gray

(5Y 7/1) with pale-brown (5YR 6/6) streaks in basal foot .............................................................................. 2-6

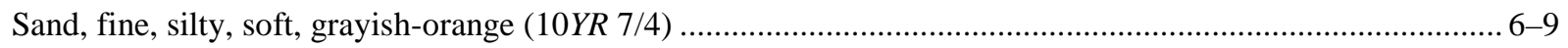

Sand, fine, silty, soft, pale-yellowish-orange (10YR 7/6)............................................................................ 9-10

Silt, clayey, sandy (very fine), very pale orange (10YR 8/2).................................................................. 10-11

Sand, fine to medium, silty; rounded quartz pebbles up to

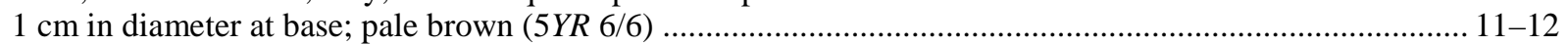

\section{UNCONFORMITY}

\section{Varina Grove unit}

Sand, fine, silty, clayey; light yellowish gray (5Y 8/2)

grading down to medium yellowish brown $(10 Y R 5 / 4)$

Sand, fine, slightly silty, soft, very light gray $(N 8) \ldots$

Sand; fine to medium grading down to fine to coarse; poorly sorted;

slightly silty; soft; pale yellowish gray (10Y 8/2) ......

Sand, fine to coarse, poorly sorted, silty, soft, olive-gray $(5 Y$ 4/2) …........................................................... 34-42

Sand, fine to coarse, poorly sorted, slightly silty, pale-olive-brown $(5 Y$ 6/6) …............................................ 42-47

Sand, fine, silty, clayey, pale-olive-brown (5Y 6/6) .................................................................................. 47-57

Sand, medium, clean but humic, olive-gray (5Y 4/1);

clayballs of lithology of unit below that are weathered

to yellowish brown (10YR 5/2), dark orange (10YR 6/8),

and dark olive gray $(5 Y 3 / 1)$. 


\section{Tar Heel Formation}

Sand, very fine to fine, clayey, lignitic, coarsely micaceous; much denser than unit above; dark olive gray (5Y 3/1) with grayish-olive-green (5GY 3/2) blotches

Base of Waccamaw Formation, Bahramsville unit: Base of Varina Grove unit:

\section{Bottomed in Tar Heel Formation}


DE-3-04: $5.17 \mathrm{mi}$ west of eastern quadrangle border, $1.47 \mathrm{mi}$ north of southern quadrangle border, at beginning of northern dirt-road fork off unnumbered paved road, 0.6 mi northwest of Shanghai, in southwestern 1/9th of map area (latitude $34.7715^{\circ} \mathrm{N}$., longitude $78.2154^{\circ} \mathrm{W}$.). Surface elevation $114 \mathrm{ft}$.

\section{LITHOLOGY}

DEPTH, IN FEET

\section{Waccamaw Formation, Bahramsville unit}

Sand, fine, clean; dusky yellowish brown (10YR 2/2) grading

down to pale yellowish brown (10YR 6/2)..... $0-1$

Sand, fine, silty, clayey; dusky yellowish brown (10YR 5/6)

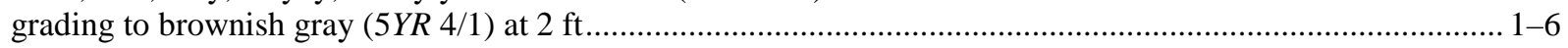

Sand, very fine, clayey, silty, light-greenish-gray $(5 G Y$ 7/1) ........................................................................... 6

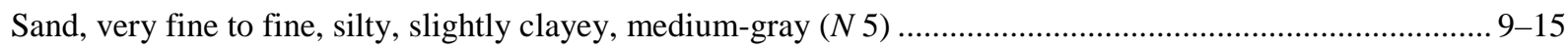

\section{UNCONFORMITY}

\section{Tar Heel Formation}

Sand, fine to medium, slightly silty, dark-yellowishorange $(10 Y R 6 / 6)$

Sand, very fine to fine, silty, clayey, micaceous, lignitic, olive-gray (5Y 4/1).....

Silt, sandy (very fine), clayey, coarsely micaceous, lignitic, olive-gray (5Y 4/1).

\section{Bottomed in Tar Heel Formation}


DE-4-04: 1.34 mi west of eastern quadrangle border, 1.03 mi north of southern quadrangle border, on dirt road $400 \mathrm{ft}$ southeast of 89-ft spot elevation point at intersection with North Carolina State Road 1129, in southeastern 1/9th of map area (latitude $34.7651^{\circ} \mathrm{N}$., longitude $78.1483^{\circ} \mathrm{W}$.). Surface elevation $87 \mathrm{ft}$.

\section{LITHOLOGY}

DEPTH, IN FEET

\section{Windsor Formation}

Sand, fine, clean; abundant roots; dusky yellowish brown (10YR 2/2) grading down through yellowish brown $(10 Y R 5 / 2)$ to very pale orange (10YR $8 / 2)$

Sand, fine, well-sorted, humic; dusky yellowish brown

(10YR 2/2) grading down through yellowish brown (10YR 5/2)

$(2-5 \mathrm{ft})$ to very dark yellowish brown $(10 Y R 3 / 2)$

Silt, clayey, sandy (very fine to fine), pale-yellowish-

brown $(10 Y R$ 6/2).

Sand, very fine to fine, silty, clayey, light-olive-gray (5Y 6/1)

Sand, fine, silty; softer than interval above; olive gray (5Y 4/1)

grading at $24 \mathrm{ft}$ to dark greenish gray (5GY 4/1)...

Sand, fine, slightly silty, massive, dark-greenish-gray

(5GY 4/1); scattered medium to coarse quartz

grains and rounded wood chips in basal foot. 26-55

\section{UNCONFORMITY}

\section{Bladen Formation}

Sand, very fine to fine, clayey, silty, dense, lignitic, darkgreenish-gray (5GY 4/1).

Sand, very fine to fine, clayey, silty, sparsely shelly, very

dark greenish gray $(5 G Y 3 / 1)^{*}$

Silt, sandy (very fine to fine); abundant shell fragments;

dark greenish gray $(5 G Y 4 / 1)$

Base of Windsor Formation:

$+32 \mathrm{ft}$ above sea level

\section{Bottomed in Bladen Formation}

*Contains a Cretaceous calcareous nannofossil Zone CC 15 or younger assemblage (Jean M. Self-Trail, USGS, oral commun., 2004). 
DE-5-04: $5.72 \mathrm{mi}$ west of eastern quadrangle border, $6.78 \mathrm{mi}$ north of southern quadrangle border, $0.05 \mathrm{mi}$ north of North Carolina State Road 1945, along dirt road, 0.7 mi west of Trinity Church, in northwestern 1/9th of map area (latitude $34.8485^{\circ} \mathrm{N}$., longitude $78.2252^{\circ} \mathrm{W}$.). Surface elevation $134 \mathrm{ft}$.

\section{LITHOLOGY}

DEPTH, IN FEET

\section{Waccamaw Formation, Bahramsville unit}

Sand, fine, slightly silty; yellowish brown (10YR 5/2)

grading down through dark grayish yellow (5Y 7/4) (1-3

$\mathrm{ft})$ to grayish yellow (5Y 8/4)

Sand, fine, silty; much stiffer than interval above; dark yellowish orange (10YR 6/6) grading down at $9 \mathrm{ft}$

to grayish orange (10YR 7/4)

Sand; fine to medium grading down to medium to

coarse; silty; light brown (5YR 5/6)

Sand, medium to coarse, dark-yellowish-orange

(10YR 6/6); abundant quartz pebbles up

to $2 \mathrm{~cm}$ in diameter

Sand, medium to coarse, silty, dark-yellowishorange (10YR 6/6); gravelly at base with rounded quartz pebbles up to $3 \mathrm{~cm}$ in diameter and lightolive-gray (5Y 6/1) clayballs

\section{UNCONFORMITY}

\section{Chowan River Formation, Coharie Member}

Silt, clayey, sandy (very fine); grades down to fine, silty, clayey sand; very dark greenish gray (5GY 3/1)

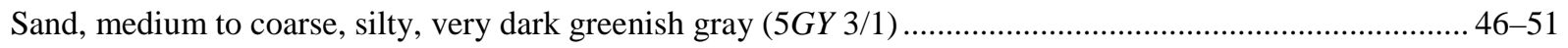

\section{Tar Heel Formation}

Silt, very clayey, lignitic, dense, stiff, dark-olive-gray (5Y 3/1) $51-54$

Sand, fine to medium, clayey, silty, micaceous; lignitic with some rounded detrital wood chips; dark olive gray (5Y 3/1); very dense and stiff; very hard drilling .....

Base of Waccamaw Formation, Bahramsville unit: Base of Chowan River Formation, Coharie Member:
$+107 \mathrm{ft}$ above sea level $+83 \mathrm{ft}$ above sea level

\section{Bottomed in Tar Heel Formation}




\section{Duart Quadrangle}

DT-1-07: $3.62 \mathrm{mi}$ west of eastern quadrangle border, $6.88 \mathrm{mi}$ north of southern quadrangle border, at entrance to dirt road on western side of North Carolina State Road 2229, $200 \mathrm{ft}$ north of Cumberland and Bladen County line, in northcentral 1/9th of map area (latitude $34.8500^{\circ} \mathrm{N}$., longitude $78.8134^{\circ} \mathrm{W}$.). Surface elevation $64 \mathrm{ft}$.

\section{LITHOLOGY}

DEPTH, IN FEET

\section{Older alluvium}

Sand, very fine to fine, silty, slightly clayey; medium yellowish brown (10YR 5/4) grading down through grayish orange (10YR 7/4) and dark yellowish orange (10YR 6.5/6) to very pale orange $(10 Y R$ 8/2).

Sand, fine to medium, silty; yellowish orange (10YR 7/6) grading down to dark yellowish orange(10YR 6/6)...

Sand, very fine, very silty and slightly clayey, very pale yellowish brown (10YR 6.5/2)

Sand, fine to medium, silty; softer than interval above; yellowish gray $(5 Y 7 / 2)$

Sand; fine to medium grading down to medium to coarse and granular; subangular to subrounded; yellowish orange (10YR 7/6)

\section{UNCONFORMITY}

\section{Tar Heel Formation}

Sand, very fine, clayey, silty, micaceous; scattered wood chips; dark gray $(N 3)$; scattered very fine, clean, very angular, very dark greenish gray (5G 3/1) sand lenses

Clay, silty, sandy (very fine), very dark greenish gray (5G 3/1);

bits of wood and pyrite lumps.....

\section{Bottomed in Tar Heel Formation}


DT-2-07: $1.70 \mathrm{mi}$ west of eastern quadrangle border, $4.74 \mathrm{mi}$ north of southern quadrangle border, $400 \mathrm{ft}$ northwest of unnumbered road, $0.11 \mathrm{mi}$ west of power line and $0.28 \mathrm{mi}$ south of Pine Acres Road, in east-central 1/9th of map area (latitude $34.8189^{\circ} \mathrm{N}$., longitude $78.7797^{\circ} \mathrm{W}$.). Surface elevation $82 \mathrm{ft}$.

\section{LITHOLOGY}

DEPTH, IN FEET

\section{Dune sand}

Sand; mostly fine but up to medium; soft; grayish brown $(5 Y R$ 3/2) grading down to dark yellowish orange $(10 Y R 6 / 6)$

Sand; mostly fine but up to medium; soft; yellowish

orange (10YR 7/6) grading down through dark yellowish orange

$10 Y R$ 5.5/6) (4-5 ft) to pale grayish orange (10YR 8/4).....

\section{UNCONFORMITY}

\section{Charles City Formation}

Silt, clayey, sandy (very fine), grayish-brown (5YR 3/2)

Silt; more clayey than interval above; sandy (very fine); olive gray (5Y 4/1); lower contact abrupt

Sand, fine to coarse, poorly sorted, feldspathic, slightly silty, soft, pale-yellowish-brown (10YR 6/2); local concentrations of subrounded to rounded quartz pebbles up to $1 \mathrm{~cm}$ in diameter

Sand, medium to very coarse, poorly sorted, medium-yellowishgray (5Y 7/1); abundant subrounded to rounded quartz pebbles up to $3 \mathrm{~cm}$ in diameter and a lignitized wood clast

\section{UNCONFORMITY}

\section{Tar Heel Formation}

Clay, silty, sandy (very fine), stiff, dense; sparse wood

fragments; dark brownish gray (5YR 3/1)

Base of dune sand:

Base of Charles City Formation:

Bottomed in Tar Heel Formation
$+70 \mathrm{ft}$ above sea level

$+44 \mathrm{ft}$ above sea level 
DT-3-07: $5.83 \mathrm{mi}$ west of eastern quadrangle border, $4.92 \mathrm{mi}$ north of southern quadrangle border, on southwestern side of North Carolina State Road 1302, 0.95 mi east of intersection with North Carolina State Road 1305, in westcentral 1/9th of map area (latitude $34.8214^{\circ} \mathrm{N}$., longitude $78.8522^{\circ} \mathrm{W}$.). Surface elevation about $142 \mathrm{ft}$.

\section{LITHOLOGY}

DEPTH, IN FEET

\section{Varina Grove unit}

Sand, fine to coarse, poorly sorted, subangular, silty, clayey, pale-yellowish-brown (10YR 6/2); lower contact somewhat gradational

Sand; fine to medium grading down to very fine to fine at $6 \mathrm{ft}$; angular to subangular; slightly clayey and silty; pale gray ( $N$ 8.5).....

Sand, fine to coarse, poorly sorted; increasingly silty downward; subrounded to rounded quartz granules; dark yellowish orange (10YR 6/6) grading down through yellowish gray (5Y 8/1) (12-12.5 ft) and pale grayish orange (10YR 8/4) (12.5-14 ft) to grayish yellow (5Y 7/4)....

Sand, very fine, silty, clayey; pale brown ( $5 Y R$ 5/2) with yellowish-orange (10YR 7/6) mottles.

Sand, medium to very coarse, poorly sorted; subrounded to rounded quartz granules and sparse subangular pebbles up to $0.5 \mathrm{~cm}$ in diameter; pale yellowish gray $(5 Y 8 / 2)$ grading down through pale grayish orange (10YR 8/4) $(26-30 \mathrm{ft})$ and yellowish gray (5Y 8/1) (30-30.5 ft) to dark reddish orange (10R 5/6)

Sand, medium to very coarse, poorly sorted; more clayey and silty than interval above; medium gray $(N 5)$ grading downward to light olive gray ( $5 Y 5 / 2$ ); scattered wood chips; clayball with black lignite and grayish-black (N 2) matrix at $33-33.5 \mathrm{ft}$

Sand, fine to medium, silty; not clayey; very wet; medium brown (5YR 4/6) grading down to medium yellowish brown (10YR 5/4); lower contact somewhat gradational

Sand, fine to medium, silty; increasingly clayey downward;

medium dark gray $(N 4)$; scattered wood chips

throughout and scattered subrounded to rounded quartz granules near base $46-48$

\section{UNCONFORMITY}

\section{Tar Heel Formation}

Clay, silty, sandy (very fine), dense, medium-dark-gray

$(N$ 4); graphite streaks from wood 
Sand, very fine to fine, clean, very micaceous;

light gray ( $N 7)$ grading down to dark bluish gray

(5B 4/1); scattered lignite clasts

$.51-55$

Base of Varina Grove unit:

+94 ft above sea level

Bottomed in Tar Heel Formation 
DT-4-07: $3.51 \mathrm{mi}$ west of eastern quadrangle border, $1.33 \mathrm{mi}$ north of southern quadrangle border, $200 \mathrm{ft}$ west of North Carolina State Highway 87, 0.1 mi north of 151-ft "Deed" benchmark in south-central 1/9th of map area (latitude $34.7694^{\circ} \mathrm{N}$., longitude $78.8112^{\circ} \mathrm{W}$.). Surface elevation $152 \mathrm{ft}$.

\section{LITHOLOGY}

DEPTH, IN FEET

\section{Varina Grove unit}

Sand; dominantly fine but occasionally very fine to medium; silty; clayey; sticky; plinthitic nodules at $4 \mathrm{ft}$; light yellowish brown (10YR 6/4) grading down through dark yellowish orange (10YR 6/6)

(2-6 ft) to reddish orange (10R 6/8).

Sand, very fine, very clayey and silty, dense, sticky, yellowish-gray (5Y 8/1).

Sand, very fine, silty, slightly clayey, light-orangepink (10R 8/4); some clay-rich lenses; lower contact somewhat gradational

Sand, fine to medium, silty, slightly clayey, mediumorange-pink (10R 6/6).

Sand, fine to medium, silty, clayey; light reddish orange

$(10 Y R$ 7/6) grading down to pale orange (10YR 8/8) at $19.4 \mathrm{ft}$

Silt, very clayey, sandy (very fine), grayish-pink ( $5 R$ 8/2)

Sand; fine to medium grading rapidly down to medium to very coarse; abundant subangular to subrounded quartz pebbles up to $3 \mathrm{~cm}$ in diameter; pale brownish orange (5YR 8/6); lower contact abrupt

\section{Tar Heel Formation}

Clay, silty, micaceous, stiff, sticky, dense; grayish orange (10YR 8/4) grading down to yellowish orange (10YR 7/6)

at $23.5 \mathrm{ft}$.

Base of Varina Grove unit:

$+129 \mathrm{ft}$ above sea level

\section{Bottomed in Tar Heel Formation}




\section{Dublin Quandrangle}

DN-1-07: $4.33 \mathrm{mi}$ west of eastern quadrangle border, $1.05 \mathrm{mi}$ north of southern quadrangle border, on eastern side of Knoxville Lane along old railroad grade, $0.35 \mathrm{mi}$ south-southeast of North Carolina Highway 41, on ridge between McNeil Bay and Sheriff White Bay, in south-central 1/9th of map area (latitude $34.6403^{\circ} \mathrm{N}$., longitude $78.7009^{\circ} \mathrm{W}$.). Surface elevation about $138 \mathrm{ft}$.

\section{LITHOLOGY}

DEPTH, IN FEET

\section{Waccamaw Formation, Moorings unit}

Sand, fine, well-sorted; pale yellowish brown

(10YR 6/2) grading down through grayish yellow

(5Y 7/4) to dark yellowish orange (10YR 6/6).

Sand, fine to medium, silty, dark-yellowish-orange

(10YR 6/6); lower contact somewhat gradational...

Sand, fine to coarse, poorly sorted; grades down through fine to medium to dominantly fine; yellowish gray $(5 Y 7 / 2)$ with light-brown $(5 Y R 5 / 6)$

mottles grading down through very pale orange $(10 Y R$ 8/2)

(5-6 ft) and pale yellowish orange (10YR 8/6) (7-9 ft)

to light grayish orange pink (5YR 8/2); lower contact

somewhat gradational

Sand; fine to medium grading down to medium; grayish orange pink (5YR 7/2) grading down through pale yellowish orange (10YR 8/6) to light yellowish gray (5Y 8/1); lower contact abrupt

\section{Waccamaw Formation, Bahramsville unit}

Silt, very clayey, sandy (very fine); very pale yellowish brown (10YR 7/2) grading down through pale brownish gray $(5 Y R 6 / 1)$ to medium gray

$(N 5)$; lower contact somewhat gradational.

Sand, very fine grading down to very fine to fine;

very silty and clayey; olive gray (5Y 4/1)

Sand, mostly fine, silty, dark-olive-gray (5Y 3/1) 28-30

\section{Waccamaw Formation, James City Member}

Sand; mostly fine but up to medium; silty; abundant chalky

shells; greenish gray $5 G Y$ 6/1)* 30-36

Coquina; fine to medium sand matrix; very silty;

pale olive gray (5Y 7/1) 36-38 
Sand; fine to medium grading down to fine to coarse;

poorly sorted; silty; sparsely shelly; olive gray

(5Y 4/1); large fragment of dusky-brown (5YR 2/2)

lignite at base

Sand; fine to coarse, poorly sorted, grading down

to fine to medium; subrounded; clean; soft; grayish

brown (5YR 3/2); scattered rounded lignite fragments

$1-2 \mathrm{~cm}$ in diameter

\section{Tar Heel Formation}

Sand, very fine to fine, very silty and clayey,

micaceous, sparsely lignitic, dense, stiff, tough;

light olive gray (5Y6/1) with dark-greenish-

gray (5G 4/1) mottles grading down through brownish

gray $(5 Y R$ 7/1) to medium grayish brown

(5YR 4/2)

Base of Waccamaw Formation, Moorings unit:

Base of Waccamaw Formation, Bahramsville unit:

Base of Waccamaw Formation, James City Member:

\section{Bottomed in Tar Heel Formation}

*Early Pleistocene calcareous nannofossil assemblage recovered at $36 \mathrm{ft}$

(Jean M. Self-Trail, USGS, oral commun., 2007).
$+124 \mathrm{ft}$ above sea level

$+108 \mathrm{ft}$ above sea level

$+86 \mathrm{ft}$ above sea level 
DN-2-07: $3.53 \mathrm{mi}$ west of eastern quadrangle border, $7.61 \mathrm{mi}$ north of southern quadrangle border, on southeastern side of North Carolina State Road 1323, 0.78 mi northeast of intersection with North Carolina Highway 53, in northcentral 1/9th of map area (latitude $34.7363^{\circ} \mathrm{N}$., longitude $78.6856^{\circ} \mathrm{W}$.). Surface elevation about $72 \mathrm{ft}$.

\section{LITHOLOGY}

DEPTH, IN FEET

\section{Dune sand}

Sand, fine to coarse, poorly sorted, soft, clean, yellowish-gray $(5 Y 8 / 1)$...

Sand, fine to medium, humate-cemented; dusky

brown (5YR 2/2) grading down at $3.5 \mathrm{ft}$ to

medium yellowish brown 10YR 5/2).

Sand, fine to medium, soft, very pale orange

(10YR 8/2).

Sand, fine to coarse, poorly sorted, soft; pale yellowish brown (10YR 7/2) grading down through

dark yellowish brown (10YR 3/2) (7-7.5 ft),

yellowish gray $(5 Y 7 / 2)(7.5-14 \mathrm{ft})$, pale

yellowish brown (10YR 6/2) (14-14.5 ft), and orange (10YR 7/8) (14.5-15 ft) to pale

grayish orange (10YR 8/4).

\section{Older alluvium}

Peat, sandy (very fine to fine), micaceous, dark-

yellowish-brown (10YR 3/2)....

Sand; dominantly medium to coarse with minor

fine fraction; soft; pale grayish orange (10YR 8/4);

lower contact somewhat gradational

Sand, medium to very coarse, poorly sorted, feldspathic, yellowish-gray (5Y 8/1); subrounded to rounded quartz pebbles up to $1 \mathrm{~cm}$ in diameter; soft; becomes silty downward...

Sand, fine to coarse, poorly sorted, granular, silty and slightly clayey, yellowish-orange (10YR 7/6) ... 


\section{Tar Heel Formation}

Sand, fine to medium, silty, clayey, micaceous,

medium-olive-gray ( $5 Y$ 5/1); dark-brown (5YR 2/4)

lignite clasts

Base of dune sand:

Base of older alluvium:

$+56 \mathrm{ft}$ above sea level

$+44 \mathrm{ft}$ above sea level

\section{Bottomed in Tar Heel Formation}


DN-3-07: $3.62 \mathrm{mi}$ west of eastern quadrangle border, $6.88 \mathrm{mi}$ north of southern quadrangle border, at southern terminus of North Carolina State Road 1334, in east-central 1/9th of map area (latitude $34.6984^{\circ} \mathrm{N}$., longitude $78.6570^{\circ} \mathrm{W}$.). Surface elevation $60 \mathrm{ft}$.

\section{LITHOLOGY}

DEPTH, IN FEET

\section{Dune sand}

Sand, fine to medium, soft, slightly silty; brownish gray (5YR 4/1) grading down to grayish orange $(10 Y R 7 / 4)$ at 2 in.

Sand, fine to medium, silty, clayey; very dark yellowish orange $(10 Y R 5 / 6)$ grading down to pale grayish orange (10YR 8/4) with light-brown (5YR 5/6) streaks

\section{UNCONFORMITY}

\section{Chuckatuck Formation}

Sand, fine to medium, silty, clayey, very light gray

$(N 8)$; root fragments.

Sand; fine to medium grading down through medium

to very coarse at $10 \mathrm{ft}$ then back to fine to medium

at $12 \mathrm{ft}$ and then back to medium to very coarse at

15-17 ft; clean; soft; yellowish gray (5Y 7/2).....

\section{UNCONFORMITY}

\section{Tar Heel Formation}

Clay, silty, micaceous, dense, stiff, dark-olive-gray

(5Y 3/1); abundant very fine sand-filled

burrows 0.5 to $1 \mathrm{~cm}$ in diameter and pyrite lumps

Base of dune sand:

Base of Chuckatuck Formation:

Bottomed in Tar Heel Formation
$+57 \mathrm{ft}$ above sea level

$+43 \mathrm{ft}$ above sea level 
DN-4-07: $3.62 \mathrm{mi}$ west of eastern quadrangle border, $6.88 \mathrm{mi}$ north of southern quadrangle border, along dirt road $0.08 \mathrm{mi}$ west of North Carolina State Road 1339, $0.6 \mathrm{mi}$ north of intersection with North Carolina State Road 1338, in west-central $1 / 9$ th of map area (latitude $34.6766^{\circ} \mathrm{N}$., longitude $78.7224^{\circ} \mathrm{W}$.). Surface elevation $140 \mathrm{ft}$.

\section{LITHOLOGY}

DEPTH, IN FEET

\section{Waccamaw Formation, Moorings unit}

Sand, very fine to fine; pale yellowish brown (10YR 6/2)

grading down to dark yellowish orange (10YR 6/6).....

Sand, very fine to fine, silty, clayey; very dark yellowish

orange (10YR 5/6) with dark-orange (10YR 6/8) mottles

Sand, very fine to fine, sugary, soft; white ( $N$ 9)

grading rapidly down to silty and light brown (5YR 5/6)

Sand, very fine to fine, slightly silty, thixotropic;

1-2 percent very fine, dark, heavy minerals; grayish

orange pink (5YR 7/2) grading down to yellowish gray

(5Y 8/1) in basal foot; lower contact abrupt

\section{Waccamaw Formation, Bahramsville unit}

Silt, very clayey, greasy, sandy (very fine); dark orange

(10YR 8/6) with yellowish-gray (5Y 8/1) blotches

Sand; very fine to fine grading down to very fine to

medium; poorly sorted; silty; yellowish gray (5Y 7/2)

Silt, very clayey, greasy, sandy (very fine); upper foot

yellowish orange (10YR 7/6) grading rapidly down to

medium gray $(N 5)$

Sand; dominantly fine to medium, but ranges from

very fine to coarse; poorly sorted; silty; dark greenish

gray $(5 G Y 3 / 1)$.

\section{UNCONFORMITY}

\section{Chowan River Formation, Coharie Member}

Sand, very fine, very clayey and silty, dense, stiff, micaceous, medium-greenish-gray (5GY 5/1)...

Sand, very fine to fine, silty, micaceous; softer than interval above; yellowish gray (5Y 7/1); lower contact somewhat gradational

Sand; fine to medium grading down to fine to coarse; poorly sorted; silty; yellowish gray (5Y 7/1) with grayish-brown (5YR 3/2) blotches; lower contact abrupt 


\section{Tar Heel Formation}

Silt, very clayey, sandy (very fine), sparsely micaceous,

stiff, dense; medium olive gray (5Y 5/1) with mediumgreenish-gray ( $5 G 5 / 1)$ mottles, lower contact somewhat gradational

Sand, very fine, silty, clayey, micaceous, dense, olivegray (5Y 4/1); thin laminae of fine sand; lignite clasts

Sand, fine to medium, silty, yellowish-brown (10YR 5/2);

lower contact abrupt.

Sand, very fine to fine, silty, very micaceous, light-olivegray (5Y 6/1); 3-in.-thick layer of clayey, carbonaceous, micaceous, dusky-brown (5YR 2/2) silt at $63 \mathrm{ft}$.

Sand, medium to coarse, silty, clayey, brownish-gray

(5YR 4/1); scattered lignite fragments.

Sand, medium to coarse, subrounded, silty, medium-brownishgray $(5 Y R 5 / 1)$

Base of Waccamaw Formation, Moorings unit:

Base of Waccamaw Formation, Bahramsville unit: Base of Chowan River Formation, Coharie Member:

$+118 \mathrm{ft}$ above sea level $+98 \mathrm{ft}$ above sea level $+91 \mathrm{ft}$ above sea level

\section{Bottomed in Tar Heel Formation}




\section{Elizabethtown North Quadrangle}

EN-1-07: $0.99 \mathrm{mi}$ west of eastern quadrangle border, $1.43 \mathrm{mi}$ north of southern quadrangle border, on northeastern side of North Carolina Highway 53, 0.4 mi east of junction with U.S. Highway 701, in southeastern 1/9th of map area (latitude $34.6460^{\circ} \mathrm{N}$., longitude $78.5174^{\circ} \mathrm{W}$.). Surface elevation $71 \mathrm{ft}$.

\section{LITHOLOGY}

DEPTH, IN FEET

Sand, fine to medium; swirled colors; disturbed ground $0-3$

\section{Dune sand}

Sand, fine, clean; dusky brown (5YR 2/2) grading down through yellowish brown (10YR 5/2) (3.5-5 ft) to grayish yellow (5Y 7/4).

Sand; fine grading down to fine to medium; clean; dark yellowish brown (10YR 4/6) grading down through very pale orange $(10 Y R$ 8/2) (6.5-8.5 ft) and through dark yellowish brown (10YR 4/4)

\section{UNCONFORMITY}

\section{Chuckatuck Formation}

Sand, fine, clayey, silty; dark reddish brown (5YR 3/4)

rapidly grading down to grayish brown (5YR $3 / 2)$.

Silt, sandy (very fine), clayey, stiff, somewhat sticky;

light gray $(N 7)$ grading down through light greenish gray

(5G 7/1) (21-24 ft) to light greenish gray (5G 7/1)

with light-olive-brown ( $5 Y$ 5/4) mottles.

Sand, fine, well-sorted, yellowish-gray (5Y 8/1);

sparse very fine, dark , heavy minerals;

lower contact somewhat gradational

Sand, fine to coarse, poorly sorted, yellowish-gray

(5Y 8/1); very fine, dark, heavy minerals

\section{Tar Heel Formation}

Clay, silty, lignitic, coarsely micaceous, dense; olive gray

(5Y 4/1) grading down to dusky brown (5YR 2/4).

Sand, fine, silty and clayey, micaceous, dark-olive-gray

(5Y 2/2) to olive-gray (5Y 4/2); interbedded with

coarsely micaceous, woody peat layers. 
Clay, silty, sandy (very fine), finely micaceous, dense, very lignitic, dark-olive-gray (5Y 3/1); medium-greenishgray (5GY 7/1), very fine sand-filled burrows about $1 \mathrm{~cm}$ in diameter in basal $2 \mathrm{ft}$.

Base of dune sand:

Base of Chuckatuck Formation:

$+54 \mathrm{ft}$ above sea level $+32 \mathrm{ft}$ above sea level

\section{Bottomed in Tar Heel Formation}


EN-2-07: 1.37 mi west of eastern quadrangle border, 7.32 mi north of southern quadrangle border, on northern side of intersection of North Carolina State Roads 1524 and 1509, on Susies Hill in northeastern 1/9th of map area (latitude $34.7311^{\circ} \mathrm{N}$., longitude $78.5234^{\circ} \mathrm{W}$.). Surface elevation $111 \mathrm{ft}$.

\section{LITHOLOGY}

DEPTH, IN FEET

\section{Dune sand}

Sand, fine to medium, slightly silty, soft, paleyellowish-orange (10YR 8/6); lower contact somewhat gradational

Sand, fine to medium, clean, soft, grayish-orange

(10YR 7.5/4)

Sand, fine to medium, silty, soft, medium-brown

(5YR 4/4)

Sand, fine to medium, clean, soft; pale yellowish orange (10YR $8 / 6)$ grading down through very pale orange $(10 Y R 8 / 2)$ and very pale orange

(10YR 8/2) with dark-yellowish-orange streaks (10YR 6/6) (23-26 ft) to pale yellowish brown $(10 Y R$ 6/2)

Sand, fine to medium, very humic, soft, dark-brown

(5YR 2/4)

\section{UNCONFORMITY}

\section{Charles City Formation}

Sand, fine to medium, subangular, very clayey, pale-yellowish-gray (5Y 8.5/1); abundant kaolinite

Sand; fine to medium grading down through medium to coarse and granular to medium to very coarse; poorly sorted; pebbly (up to $3 \mathrm{~cm}$ diameter); soft; slightly silty; pale yellowish brown (10Y 6/2) grading down through dark yellowish brown (10YR 4/4) to light yellowish brown (10YR 6/4).

\section{Tar Heel Formation}

Sand, fine to medium, silty, clayey, coarsely micaceous, dark-reddish-brown (5YR 3/4); locally abundant lignitized wood;

much denser than unit above; dark yellowish brown

(10YR 4/2) grading down to olive gray (10Y 6/1)... 
Clay, slightly lignitic, finely micaceous, dense, massive, olive-gray (5Y 4/2)

$60-61$

Base of dune sand:

+77 ft above sea level

Base of Charles City Formation:

+63 ft above sea level

Bottomed in Tar Heel Formation 
EN-3-07: $6.11 \mathrm{mi}$ west of eastern quadrangle border, $1.76 \mathrm{mi}$ north of southern quadrangle border, on southern side of North Carolina Highway 53, 0.85 mi west of intersection with North Carolina Highway 242, in southwestern 1/9th of map area (latitude $34.6506^{\circ} \mathrm{N}$., longitude $78.6065^{\circ} \mathrm{W}$.). Surface elevation $48 \mathrm{ft}$.

\section{LITHOLOGY}

DEPTH, IN FEET

\section{Older alluvium}

Sand; mostly fine but up to medium; clean; contains

less than 1 percent very fine to fine, dark, heavy minerals;

dark yellowish brown (10YR 4/2) grading down

through grayish orange $(10 Y R$ 7/4) $(0.5-2 \mathrm{ft})$,

yellowish orange (10YR 7/6) (2-3 ft), and very

pale orange (10YR 8/2) (3-4 ft) to pale yellowish

brown $(10 Y R 6 / 2)$

Sand, medium to coarse, subrounded, soft, clean, pale-

yellowish-brown (10YR 7/2)....

\section{UNCONFORMITY}

\section{Tar Heel Formation}

Clay, silty, dense, stiff, dark-olive-gray (5Y 3/1);

3-in.-thick layer.

Sand; dominantly fine but up to medium; silty; slightly micaceous; olive gray (5Y 4/1) to medium gray $(N 5)$;

very dark reddish brown (10R $2 / 4)$ lignite clasts .

\section{Base of older alluvium:}

$+38 \mathrm{ft}$ above sea level

\section{Bottomed in Tar Heel Formation}


EN-4-07: $6.42 \mathrm{mi}$ west of eastern quadrangle border, $7.28 \mathrm{mi}$ north of southern quadrangle border, on southwestern side of North Carolina State Road 1324, 0.22 mi northwest of intersection with North Carolina Highway 242, in northwestern 1/9th of map area (latitude $34.7306^{\circ} \mathrm{N}$., longitude $78.6121^{\circ} \mathrm{W}$.). Surface elevation $85 \mathrm{ft}$.

\section{LITHOLOGY}

DEPTH, IN FEET

\section{Dune sand}

Sand, fine to medium, subrounded to rounded, soft;

very pale yellowish brown (10YR 7/2), grading

down to dusky brown (5YR 2/2) at $1 \mathrm{ft}$

Peat, sandy (very fine), dark-brown (5YR 2/4);

wood clast near base

Sand, fine to medium, subrounded to rounded, silty,

medium-brown (5YR 4/6).

Sand; dominantly fine but up to medium; subangular

to subrounded; silty; soft; medium-brown (5YR 4/6).

\section{Charles City Formation}

Silt, very clayey, stiff; light greenish gray ( $5 G$ 8/1)

grading down through light greenish gray $(5 G$ 8/1) with

light-olive-brown (5Y 5/4) mottles (11-19 ft) to light

olive brown ( $5 Y 5 / 4)$ with light-greenish-gray

(5G 8/1) mottles; lower contact somewhat gradational.

Sand, very fine, very clayey and silty; softer than

interval above; light greenish gray (5G 8/1)

Sand; fine to medium grading rapidly down to medium to

coarse; slightly silty to clean; pale yellowish brown

(10YR 7/2); lower contact gradational.

Sand, medium to very coarse, pale-yellowish-brown

(10YR 7/2); abundant subrounded quartz pebbles up to $4 \mathrm{~cm}$ in

diameter in basal few inches

\section{Tar Heel Formation}

Clay, very silty, dark-brownish-gray (5YR 3/1);

abundant yellowish-orange (10YR 7/6) and dark-brown

(5YR 2/4) lignite.

Base of dune sand:

Base of Charles City Formation:

\section{Bottomed in Tar Heel Formation}

$+77 \mathrm{ft}$ above sea level

$+43 \mathrm{ft}$ above sea level 
EN-5-07: $3.70 \mathrm{mi}$ west of eastern quadrangle border, $4.66 \mathrm{mi}$ north of southern quadrangle border, on dirt road 0.06 mi east of junction with North Carolina State Road 1511 (junction is location of 63-ft spot elevation), in central 1/9th of map area (latitude $34.6925^{\circ} \mathrm{N}$., longitude $78.5654^{\circ} \mathrm{W}$.). Surface elevation $64 \mathrm{ft}$.

\section{LITHOLOGY}

DEPTH, IN FEET

\section{Dune sand}

Sand, fine to medium, subrounded to round, humic;

dusky brown (5YR 2/2) grading down to light

yellowish brown (10YR 6/4)

Sand; dominantly fine but up to medium; silty;

very pale yellowish brown (10YR 7/2) grading

down to light brown (5YR 5/6).....

Sand; dominantly fine but up to medium;

humic; pale brown (5YR 5/26)

\section{Chuckatuck Formation}

Sand; dominantly fine but ranges from very fine

to medium; poorly sorted; subangular to subrounded;

humic slightly silty; medium brown (5YR 4/6)

Sand, medium to very coarse, poorly sorted; medium

brown $(5 Y R 4 / 6)$ grading down to yellowish

brown $(10 Y R$ 6/2) at $19 \mathrm{ft}$; lower contact gradational

Sand, coarse to very coarse, dark-brown (5YR 2/4);

abundant subrounded to rounded quartz pebbles

up to $1 \mathrm{~cm}$ in diameter.

\section{UNCONFORMITY}

\section{Tar Heel Formation}

Sand, very fine to fine, very clayey and silty, dense,

brownish-gray (5YR 4/1)

Clay, very silty, micaceous; light grayish green (10G 3/2)

interbedded with dark olive gray (5Y 3/1); medium-brown

(5YR 4/6) lignite clasts; burrows filled with very fine,

pale-yellowish-gray (5Y 9/1) sand in basal $2 \mathrm{ft}$.

Base of dune sand:

Base of Chuckatuck Formation:

\section{Bottomed in Tar Heel Formation}

$+58 \mathrm{ft}$ above sea level

$+37 \mathrm{ft}$ above sea level 


\section{Elizabethtown South Quadrangle}

ES-1-07: $5.58 \mathrm{mi}$ west of eastern quadrangle border, $4.55 \mathrm{mi}$ north of southern quadrangle border, along dirt road (not on map) $0.12 \mathrm{mi}$ east of North Carolina State Road 1700, $0.75 \mathrm{mi}$ south of junction with North Carolina State Road 1708 , in west-central $1 / 9$ th of map area (latitude $34.5661^{\circ} \mathrm{N}$., longitude $78.5976^{\circ} \mathrm{W}$.). Surface elevation $116 \mathrm{ft}$.

\section{LITHOLOGY}

DEPTH, IN FEET

\section{Waccamaw Formation, Bahramsville unit}

Sand, very fine to fine, silty, clayey; grayish orange (10YR 7/4)

with dark-yellowish-orange (10YR 6/6) streaks in upper $1 \mathrm{ft}$,

then medium brown (5YR 4/6) with grayish-orange (10YR 7/4)

mottles and dark yellowish orange (10YR 6/6)

Sand; very fine to fine grading down to very fine; silty;

clayey; yellowish gray (5Y 7/2); clay content increases

downward; lower contact somewhat gradational....

Silt, very clayey, sandy (very fine), stiff, dense; pale

olive gray (5Y 6/2) with pale-yellowish-orange (10YR 8/6)

streaks grading down through pale olive gray $(10 Y R$ 8/6)

(8-12 ft) to greenish gray (5GY 6/1) with dark-yellowish-orange

(10YR 6/6) streaks, yellowish orange (10YR 7/6), pale

yellowish orange (10YR 8/6), and medium olive brown (5Y 4/4)

Silt, very clayey, sandy (very fine), stiff, dense; greenish

gray (5GY 6/1) intermingled with medium gray $(N 5)$;

lower contact somewhat gradational

Waccamaw Formation, James City Member

Sand, very fine to medium, very clayey and silty,

olive-gray (5Y 4/1); sparse thin shells; lower

contact abrupt

Sand, fine, well-sorted, very light gray ( $N$ 8);

abundant shell hash (mostly oyster).

Coquina; fine to coarse quartz sand matrix; very light

gray ( $N$ 8); subrounded pyrite lumps up to $2 \mathrm{~cm}$ in

diameter abundant in basal foot .....

\section{UNCONFORMITY}

\section{Tar Heel Formation}

Clay, silty, sandy (very fine), dense, dark-olive-gray

(5Y 3/1); abundant pyrite nodules $1-2 \mathrm{~cm}$ diameter;

scattered very light gray $(N$ 8) to white $(N 9)$,

very fine sand-filled burrows up to $1 \mathrm{~cm}$ in diameter

Base of Waccamaw Formation, Bahramsville unit:

Base of Waccamaw Formation, James City Member:
$+82 \mathrm{ft}$ above sea level

$+72 \mathrm{ft}$ above sea level

\section{Bottomed in Tar Heel Formation}


ES-2-07: $3.22 \mathrm{mi}$ west of eastern quadrangle border, $0.34 \mathrm{mi}$ north of southern quadrangle border, at entrance to dirt road on eastern side of North Carolina State Road 1708, $0.36 \mathrm{mi}$ north-northeast of southern quadrangle border along trace of road, in south-central 1/9th of map area (latitude $34.5049^{\circ} \mathrm{N}$., longitude $78.5561^{\circ} \mathrm{W}$.). Surface elevation $98 \mathrm{ft}$.

\section{LITHOLOGY}

DEPTH, IN FEET

\section{Waccamaw Formation, Bahramsville unit}

Sand, very fine to fine, slightly silty; light yellowish brown (10YR 6/4) grading down through grayish yellow (5Y $7 / 4)$ to pale grayish orange $(10 Y R$ 8/4) .

Sand, very fine to fine, very silty and clayey, stiff; dark yellowish orange (10YR 6/6) with reddishorange $(10 R 5 / 6)$ and very light gray $(N 8)$ streaks

Silt, clayey, sandy (very fine), stiff, sticky; sparse very fine mica; dark yellowish orange (10YR 6/6) with reddish-orange (10R 5/6) and very light gray $(N 8)$ streaks; lower contact somewhat gradational

Silt, sandy (very fine), clayey, yellowish-orange (10YR 7/6); lower contact somewhat gradational.

Sand, very fine to fine, slightly silty; grayish orange

(10YR 7/4) grading to yellowish gray (5Y 8/1) at $19.5 \mathrm{ft}$;

sparse very fine to fine, silvery mica.

Sand, very fine to fine, silty, soft; orange (10YR 7/8)

mingled with light yellowish brown (10YR 6/4);

interbedded with centimeter-scale layers of yellowish-

gray $(5 Y 8 / 1)$, clayey silt

Silt, very clayey, sandy (very fine), yellowish-gray $(5 Y 7 / 2)$

Sand, very fine to fine, silty, dark-greenish-gray

(5GY 4/1); clay content increases downward; centimeter-scale, clayey, silt lenses scattered throughout interval

\section{Waccamaw Formation, James City Member}

Sand, fine to medium, silty, medium-greenish-gray

(5GY 5/1); moderately abundant shell hash (mostly oyster)

Sand, fine to coarse (modally medium), dark-gray (5Y 3/1);

coarse fraction rounded; clean; basal foot contains

brownish-black (5YR 2/1) lignite lumps and clayballs

39-44

Base of Waccamaw Formation, Bahramsville unit:

$+63 \mathrm{ft}$ above sea level

\section{Bottomed in Waccamaw Formation, James City Member}


ES-3-07: $3.44 \mathrm{mi}$ west of eastern quadrangle border, $6.57 \mathrm{mi}$ north of southern quadrangle border, on southwestern side of North Carolina Highway 87, 1.5 mi northwest of junction with North Carolina State Road 1709, in north-central 1/9th of map area (latitude $34.5954^{\circ} \mathrm{N}$., longitude $78.5597^{\circ} \mathrm{W}$.). Surface elevation $107 \mathrm{ft}$.

\section{LITHOLOGY}

DEPTH, IN FEET

\section{Waccamaw Formation, Bahramsville unit}

Sand, very fine to fine, silty; grayish brown $(5 Y R 3 / 2)$

grading down to light yellowish brown (10YR 6/4) $0-1$

Sand, fine to coarse (modally medium), silty, clayey,

dense; dark yellowish orange (10YR 6/6) with reddish-brown

mottles $(10 R 5 / 6)$ below $6 \mathrm{ft}$

Silt, very clayey, stiff, dense; light olive gray (5Y 6/1)

with reddish-brown (10R 5/6) mottles

Sand, very fine to fine; pale yellowish orange (10YR 8/6)

grading down through light brown (5YR 5/6) (8-9 ft) to

light yellowish brown (10YR 6/4)...

Sand, very fine, silty, very clayey; light red (5R 6/6) with

yellowish-gray $(5 Y 7 / 2)$ streaks.

Sand very fine, silty, pale-yellowish-orange (10YR 8/6)....

Silt, very clayey, sandy (very fine), tough, dense; grayish

orange (10YR 7/4) grading down through grayish orange pink

(5YR 7/2) (12.5-13.5 ft) to light olive gray (5Y 6/1);

lower contact somewhat gradational

Sand, very fine to fine, silty, clayey; light brown

(5YR 5/6) grading down to light yellowish brown (10YR 6/4)

Sand, fine to medium, silty; light brown (5YR 5/6)

grading down through pale reddish brown $(10 R 5 / 6)$

$(26-27 \mathrm{ft})$ and grayish yellow (5Y 7/4) (27-28 ft)

to light brown (5YR 6/4)...

Sand, very fine to fine, micaceous, yellowish-orange

(10YR 7/6); interbedded with very clayey, light-

olive-gray (5Y 6/1) silt

Sand, very fine to fine, very clayey and silty, micaceous, dark olive gray (5Y 3/1);

abundant burrows filled with sand (very fine

to fine), clean, light greenish gray (5GY 7/1); some

dark-brown (5YR 2/4) lignite fragents.

\section{Waccamaw Formation, James City Member}

Sand, medium to coarse, clean, dark-greenish-gray

( $5 G 3 / 1)$; sparse shell fragments 


\section{Tar Heel Formation}

Silt, very clayey, dense, stiff, finely micaceous, dark-olive-gray (5Y 3/1)

38-46

Base of Waccamaw Formation, Bahramsville unit:

Base of Waccamaw Formation, James City Member:
+72 ft above sea level $+69 \mathrm{ft}$ above sea level

\section{Bottomed in Tar Heel Formation}


ES-4-08: $5.88 \mathrm{mi}$ west of eastern quadrangle border, $6.96 \mathrm{mi}$ north of southern quadrangle border, along dirt road 200 $\mathrm{ft}$ of junction with North Carolina State Road 1700, 0.50 mi north of junction with North Carolina State Road 1705, in northwestern 1/9th of map area (latitude $34.6007^{\circ} \mathrm{N}$., longitude $78.6027^{\circ} \mathrm{W}$.). Surface elevation about $132 \mathrm{ft}$.

\section{LITHOLOGY}

DEPTH, IN FEET

\section{Waccamaw Formation, Moorings unit}

Sand, fine; well-sorted, but with scattered coarse to very coarse grains; silty; yellowish brown (10YR 5/2) grading down to yellowish orange (10YR 6.5/6)

Sand, fine, well-sorted, silty; medium yellowish brown (10YR 5/4) grading down through grayish orange

pink (5YR 7/2) (3-5 ft) to pale brown (5YR 5/2)

Sand, fine, very silty, pale-yellowish-brown

(10YR 6/2); dark-reddish-brown (10YR 3/2)

wood fragments*

Sand, fine, slightly silty; yellowish gray (5Y 8/1)

grading down through pale brown (5YR 6/2) to light

grayish brown (5YR 4/2)

\section{Waccamaw Formation, Bahramsville unit}

Silt, clayey, sandy (very fine), sticky, stiff; light olive gray

(5Y 5.5/2) grading down to medium olive gray (5Y 5/1)

Sand, very fine to fine, clayey, silty, light-olive-gray

( $5 Y$ 5/2); lower contact gradational......

Sand, very fine to fine, very silty, slightly clayey, olive-gray (5Y 4/1)

Base of Waccamaw Formation, Moorings unit:

\section{Bottomed in Waccamaw Formation, Bahramsville unit}

*Wood fragment at base of peat yielded a radiocarbon age greater than 51,800 B.P.

(John P. McGeehin, USGS, written commun., 2008). 


\section{Garland Quadrangle}

GA-1-05: $1.78 \mathrm{mi}$ west of eastern quadrangle border, $4.56 \mathrm{mi}$ north of southern quadrangle border, at intersection of old railroad right-of-way and end of unnumbered paved road 1/9 mi east-northeast of Green Bridge, in central 1/9th of map area (latitude $34.8163^{\circ} \mathrm{N}$., longitude $78.4237^{\circ} \mathrm{W}$.). Surface elevation $115 \mathrm{ft}$.

\section{LITHOLOGY}

DEPTH, IN FEET

Railroad roadbed fill $0-2$

\section{Dune sand}

Sand, fine to medium, slightly silty; dark yellowish brown $(10 Y R$ 4/2) grading down through pale yellowish brown (5YR 6/2) (3-5 ft) to yellowish gray (5Y 8/1); lower contact somewhat gradational

\section{UNCONFORMITY}

\section{Waccamaw Formation, Bahramsville unit}

Sand; very fine to fine grading down to medium to coarse near base; very clayey and silty; stiff; dense; pale olive gray ( $5 Y 5 / 1$ ) grading near base to pale orange (5YR 7/2); scattered quartz granules and pebbles up to $0.7 \mathrm{~cm}$ in diameter.

\section{Tar Heel Formation}

Sand, very fine, very clayey and silty, finely micaceous, very dense, dark-greenish-gray ( $5 G Y 3 / 1)$

Base of dune sand:

Base of Waccamaw Formation, Bahramsville unit:
$+103 \mathrm{ft}$ above sea level

$+84 \mathrm{ft}$ above sea level

\section{Bottomed in Tar Heel Formation}


GA-2-05: $1.62 \mathrm{mi}$ west of eastern quadrangle border, $6.22 \mathrm{mi}$ north of southern quadrangle border, $0.05 \mathrm{mi}$ south of North Carolina State Road 1207, 0.95 mi east-northeast of intersection of North Carolina State Road 1207 and North Carolina Highway 411 , in northeastern $1 / 9$ th of map area (latitude $34.8402^{\circ} \mathrm{N}$., longitude $78.4032^{\circ} \mathrm{W}$.). Surface elevation $106 \mathrm{ft}$.

\section{LITHOLOGY}

DEPTH, IN FEET

\section{Dune sand}

Sand, medium to coarse, slightly silty; dusky yellowish brown (10YR 2/2) grading down through grayish brown (5YR 3/2) to pale yellowish brown (10YR 6/2)

Sand; medium to coarse grading down to fine to medium; silty; slightly humic in lower part; yellowish gray (5Y 7/2) grading down to medium brown (5YR 4/2)

at $2 \mathrm{ft}$; abundant wood material (stump?) at base..... $1-12$

\section{UNCONFORMITY}

\section{Windsor Formation}

Sand; fine grading down to medium to coarse; silty; pale grayish orange (10YR 8/4) grading down to very pale yellow (5Y 9/1).

Sand, fine to medium, silty, very pale orange (10YR 8/2). $16-17$

Silt, sandy (very fine), slightly clayey, light-gray ( $N 7)$.

Sand, very fine grading down to fine to medium; light gray ( $N$ 7).

Sand, fine to medium, pale-yellowish-gray (5Y 8/2). 31-34

Sand; fine to medium grading down to medium to coarse; silty; pale yellowish gray ( $5 Y$ 8/2); denser than interval above.

Base of dune sand:

\section{Bottomed in Windsor Formation}


GA-3-05: $5.98 \mathrm{mi}$ west of eastern quadrangle border, $7.98 \mathrm{mi}$ north of southern quadrangle border, just south of intersection of dirt road with North Carolina State Road 1214 at 146-ft spot elevation, in northwestern 1/9th of map area (latitude $34.8658^{\circ} \mathrm{N}$., longitude $78.4795^{\circ} \mathrm{W}$.). Surface elevation $144 \mathrm{ft}$.

\section{LITHOLOGY}

DEPTH, IN FEET

\section{Dune sand}

Sand, medium, clean and soft; pale yellowish brown $(10 Y R$ 6/2) over dark yellowish brown $(10 Y R 4 / 2)$

Sand; medium grading down to medium to coarse;

clean; soft; dark yellowish brown (10YR 4/2)

grading down to pale yellowish brown (10YR 7/2).

Sand, medium to coarse, humic, dusky-yellowish-

brown $(10 Y R 2 / 2)$.

Sand, fine to medium, clean to slightly silty;

medium yellowish brown (10YR 5/4) grading

down to pale yellowish brown (10YR 7/2) at $25 \mathrm{ft}$;

lower contact abrupt but no lag bed.....

\section{UNCONFORMITY}

\section{Waccamaw Formation, Bahramsville unit}

Silt, clayey, sandy (very fine); scattered fine to

medium grains; sticky and moderately dense; light

olive gray (5Y 6/1) grading down in basal foot to

olive gray ( $5 Y 4 / 1)$

Sand, very fine to medium, clayey, silty, olive-black

(5Y 2/1); wood fragments.

Sand, medium to very coarse, poorly sorted, slightly

silty; medium olive gray ( $5 Y 5 / 1)$ grading down in

basal foot to pale olive gray (5Y 7/1); abrupt basal

contact but no lag bed

Silt, very clayey, sandy (very fine), medium-greenishgray $(5 G Y 5 / 1)$...

Sand, medium to coarse, silty, medium-olive-gray

$(5 Y 5 / 1)$

Silt, clayey, dark-greenish-gray (5GY 4/1).

Gravel; angular to rounded quartz clasts up to 3.5

$\mathrm{cm}$ in diameter; dark greenish gray (5GY 4/1);

peaty in basal 4 in.

Base of dune sand:

$+116 \mathrm{ft}$ above sea level

\section{Bottomed in Waccamaw Formation, Bahramsville unit}


GA-4-05: $6.36 \mathrm{mi}$ west of eastern quadrangle border, $1.30 \mathrm{mi}$ north of southern quadrangle border, on southern side of North Carolina State Road 1002 just south of abandoned house located 0.15 mi southeast of Sinai Church, in southeastern 1/9th of map area (latitude $34.7692^{\circ} \mathrm{N}$., longitude $78.4859^{\circ} \mathrm{W}$.). Surface elevation $91 \mathrm{ft}$.

\section{LITHOLOGY}

DEPTH, IN FEET

\section{Windsor Formation}

Sand, very fine to fine, silty, clayey; dark yellowish brown

(10YR 4/2) grading down to yellowish brown (10YR 5/2)......

Sand; very fine to fine grading down to fine; dark yellowish

orange (10YR 6/6) grading down through dark yellowish orange

$(10 Y R$ 6/6) with reddish-brown (10R 5/6) and pale-olive-gray

(5Y 7/1) mottles (2-4 ft) to pale olive gray (5Y 7/1);

lower contact somewhat gradational

Sand, medium to coarse, pale-orange (10YR 7/2); lower contact

somewhat gradational

Sand, medium to very coarse, angular to subangular, poorly

sorted, pale-olive-gray (5Y 7/1); lower contact gradational.

Sand, coarse to very coarse, granular, slightly silty;

light olive gray ( $5 Y$ 6/1) to olive gray ( $5 Y 4 / 1)$;

angular metamorphic pebble $1.5 \mathrm{~cm}$ in diameter

\section{UNCONFORMITY}

\section{Tar Heel Formation}

Sand, very fine to fine, silty, clayey, micaceous, lignitic, dark-greenish-gray (5GY 4/1)

\section{Base of Windsor Formation:}

$+60 \mathrm{ft}$ above sea level

\section{Bottomed in Tar Heel Formation}


GA-5-05: $0.83 \mathrm{mi}$ west of eastern quadrangle border, $1.98 \mathrm{mi}$ north of southern quadrangle border, along old railroad right-of-way at southeastern edge of town of Garland, 0.4 mi northwest of Evening Light Church, in southeastern 1/9th of map area (latitude $34.7789^{\circ} \mathrm{N}$., longitude $78.3894^{\circ} \mathrm{W}$.). Surface elevation $134 \mathrm{ft}$.

\section{LITHOLOGY}

DEPTH, IN FEET

Railroad roadbed fill

\section{Dune sand}

Sand, fine to coarse, silty, humic; dusky yellowish brown (10YR 2/2) grading down through yellowish brown (10YR 5/2) (4-18ft) and medium yellowish brown $(10 Y R$ 5/4) (18-30 ft) to yellowish orange (10YR 7/6); a few zones in this interval humate cemented; lower contact abrupt.

\section{UNCONFORMITY}

\section{Windsor Formation}

Silt, very clayey, dense and stiff; dark yellowish orange

(10YR 6/6) grading down to light olive gray (5Y 6/1)..... 32-35

Silt, clayey, sandy (very fine), greenish-gray (5GY 6/1).

Sand, fine, silty, micaceous, light-greenish-gray

(5GY 7/1), lower contact somewhat gradational

Sand; medium to coarse grading down to medium to very coarse and granular with small quartz pebbles up to $1 \mathrm{~cm}$ in diameter; pale yellowish gray (5Y 8/2)

\section{UNCONFORMITY}

\section{Tar Heel Formation}

Silt, clayey, micaceous, dense, dark-greenish-gray (5GY 3/1).

Base of dune sand:

Base of Windsor Formation:
$+102 \mathrm{ft}$ above sea level

$+68.5 \mathrm{ft}$ above sea level

\section{Bottomed in Tar Heel Formation}




\section{Harrells Quadrangle}

HA-1-04: $1.21 \mathrm{mi}$ west of eastern quadrangle border, $2.93 \mathrm{mi}$ north of southern quadrangle border, on western side of U.S. Highway 421, 0.45 mi north-northwest of intersection of North Carolina State Road 1211 with U.S. Highway 421, in east-central 1/9th of map area (latitude $34.6675^{\circ} \mathrm{N}$., longitude $78.1461^{\circ} \mathrm{W}$.). Surface elevation $81 \mathrm{ft}$.

\section{LITHOLOGY}

DEPTH, IN FEET

\section{Dune sand}

Sand, fine to medium, subangular, silty, light-olive-brown (5Y 5/4)

\section{Windsor Formation}

Sand, very fine to fine, clayey, silty; medium brownish gray (5YR 5/1) with yellowish-gray (5Y 7/1) mottles

Sand; very fine to fine interbedded with fine to medium;

clayey; silty; yellowish gray (5Y 8/1) grading down to

grayish orange pink (5YR 7/2)

Silt, clayey, sandy (very fine), yellowish-orange (10YR 7/6)

Silt, clayey, intermittently sandy (very fine); medium gray

$(N 5)$ grading down through medium greenish gray (5GY 5/1)

to dark greenish gray (5GY 4/1)

Sand; fine grading down to fine to medium; slightly silty; dark greenish gray (5GY 4/1); scattered wood fragments and small quartz pebbles near base

\section{UNCONFORMITY}

\section{Bladen Formation}

Sand, fine to medium, silty, olive-gray ( $5 Y 3 / 2)$ $24-26$

Sandstone, fine to medium, calcite-cemented, medium-olive-gray ( $5 Y$ 5/1) $26-28$

Sand, fine to medium, silty, calcareous, olive-gray (5Y 3/2)

Base of dune sand:

Base of Windsor Formation:

\section{Bottomed in Bladen Formation}

$+79 \mathrm{ft}$ above sea level $+57 \mathrm{ft}$ above sea level 
HA-2-04: $6.07 \mathrm{mi}$ west of eastern quadrangle border, $5.21 \mathrm{mi}$ north of southern quadrangle border, along northwest side of dirt road, $0.3 \mathrm{mi}$ south-southwest of intersection with North Carolina State Road 1118, $0.8 \mathrm{mi}$ north-northwest of intersection of North Carolina State Road 1118 and 1007, in west-central 1/9th of map area (latitude $34.7007^{\circ} \mathrm{N}$., longitude $78.2310^{\circ} \mathrm{W}$.). Surface elevation $80 \mathrm{ft}$.

\section{LITHOLOGY}

DEPTH, IN FEET

\section{Windsor Formation}

Sand, fine to medium, soft, humic; medium brown

(5YR 4/6) grading down to dusky brown (5YR 2/2)

Sand, fine to medium, well-sorted, subangular; slightly

silty and clayey in basal foot; yellowish gray (5Y 8/1) .

Sand, fine to medium, silty; pale orange (10YR 8/2)

grading down through light yellowish brown (10YR 7/4)

(8-9 ft) to dark yellowish orange (10YR 6/6).

\section{UNCONFORMITY}

\section{Tar Heel Formation}

Sand, very fine to fine; interbedded with clay; micaceous;

lignitic; dark olive gray (5Y 3/1) grading down

at 3 in. to dark greenish gray $(5 G Y 3 / 1)$.

$19-21$

Base of Windsor Formation:

+61 ft above sea level

\section{Bottomed in Tar Heel Formation}


HA-3-04: $5.56 \mathrm{mi}$ west of eastern quadrangle border, $3.11 \mathrm{mi}$ north of southern quadrangle border, on western side of abandoned house, $0.05 \mathrm{mi}$ east of North Carolina State Road 1106, in west-central 1/9th of map area (latitude $34.6702^{\circ} \mathrm{N}$., longitude $78.2222^{\circ} \mathrm{W}$.). Surface elevation $78 \mathrm{ft}$.

\section{LITHOLOGY}

DEPTH, IN FEET

\section{Charles City Formation}

Sand, fine to medium, clean; dark yellowish brown (10YR 4/2) grading down to light yellowish brown $(10 Y R$ 6/4)

Sand, fine to medium, very humic; yellowish brown

(10YR 5/2) grading down to dusky brown (10YR 2/2)

Sand, very fine to fine, clayey, silty, pale-brown ( $5 Y R$ 5/2)

Sand; fine to medium grading down to fine to coarse; poorly sorted; clean; thixotropic; dark reddish brown (5YR 3/4)

\section{UNCONFORMITY}

\section{Tar Heel Formation}

Sand, very fine to fine, micaceous, dense, dark-greenishgray (5GY 4/1); clay lenses and lignite in basal foot.

Sandstone, fine to medium, calcite-cemented, medium-olive-

gray $(5 Y 5 / 1)$

Sand, fine to medium, silty, calcareous, olive-gray (5Y 3/2)

Base of Charles City Formation:

$+62 \mathrm{ft}$ above sea level

\section{Bottomed in Tar Heel Formation}


HA-4-04: $3.17 \mathrm{mi}$ west of eastern quadrangle border, $7.59 \mathrm{mi}$ north of southern quadrangle border, at northwestern end of dirt road, $0.3 \mathrm{mi}$ northwest of Peterson Cemetery, in north-central 1/9th of map area (latitude $34.7355^{\circ} \mathrm{N}$., longitude $78.1802^{\circ} \mathrm{W}$.). Surface elevation $73 \mathrm{ft}$.

\section{LITHOLOGY}

DEPTH, IN FEET

\section{Charles City Formation}

Sand, fine, silty; dark yellowish brown (10YR 3/2) grading

down at $1 \mathrm{ft}$ to light yellowish brown (10YR 6/4)..... $0-4$

Sand, very fine to fine, silty and clayey, stiff, yellowishgray $(5 Y 8 / 1)$

Sand, fine to medium, soft, silty, yellowish-orange (10YR 7/6).

Sand, medium to coarse, clean, slightly silty, grayish-yellow

(5Y 8/4); abrupt contact with bed below

\section{Windsor Formation}

Silt, clayey, sandy (very fine), very stiff and dense; yellowish orange $(10 Y R$ 7/6) with very light gray $(N 8)$ and medium-reddish-brown (10R 4/6) mottles in basal $2 \mathrm{ft}$

\section{Duplin Formation}

Sand, fine to medium, subangular, silty, slightly clayey, dark-yellowish-orange (10YR 5.5/6); softer than unit above..

Sand; fine to medium grading down to medium to coarse;

Sand, medium to coarse, shelly, dark-yellowish-orange

Coquina, quartzose, pale-olive (10Y 6/2); abundant echinoid spines and bryozoans

Sand, medium to coarse, shelly; pale olive (10Y 6/2)

grading down to medium light gray $(N 6)$....

Base of Charles City Formation:

$+64 \mathrm{ft}$ above sea level

Base of Windsor Formation:

\section{Bottomed in Duplin Formation}


HA-5-04: $2.77 \mathrm{mi}$ west of eastern quadrangle border, $3.09 \mathrm{mi}$ north of southern quadrangle border, on road through Gap Bay, $0.35 \mathrm{mi}$ northeast of road intersection at 85-ft spot elevation, in central 1/9th of map area (latitude $34.6699^{\circ} \mathrm{N}$., longitude $78.1731^{\circ} \mathrm{W}$.). Surface elevation $85 \mathrm{ft}$.

\section{LITHOLOGY}

DEPTH, IN FEET

Road fill $0-1$

\section{UNCONFORMITY}

\section{Carolina Bay fill}

Peat, compact, greasy, dusky-yellowish-brown (10YR 2/2); wood fragments*

\section{Windsor Formation}

Silt, clayey, sandy (very fine); medium yellowish brown (10YR 5/4) grading down to yellowish gray (5Y 7/2)....

Silt, soft, medium-greenish-gray ( $5 G 5 / 1)$; lower contact abrupt

Silt, sandy (very fine), clayey, dark-greenish-gray (5G 4/1);

much denser than interval above.

Silt, sandy (very fine), clayey, olive-black (5Y 2/1);

wood fragments.

Silt, sandy (very fine), clayey, dark-greenish-gray (5G 4/1).

Silt, sandy (very fine), shelly, dark-greenish-gray (5G 4/1).

Silt, clayey, dark-greenish-gray (5G 4/1); very calcareous

but no shells

Sand; very fine to fine grading down to fine to medium;

sparsely shelly; very calcareous; dark greenish gray (5G 4/1).

Sand, medium to coarse, dark greenish gray (5GY 4/1);

phosphate granules and wood fragments ....

\section{Base of Carolina Bay fill:}

$+81 \mathrm{ft}$ above sea level

\section{Bottomed in Windsor Formation}

*Wood fragment at base of peat yielded a radiocarbon age of 2,050 \pm 40 years B.P. (John P. McGeehin, USGS, written commun., 2005). 
HA-6-04: $2.11 \mathrm{mi}$ west of eastern quadrangle border, $2.83 \mathrm{mi}$ north of southern quadrangle border, on road through Gap Bay where road crosses the southeastern sand rim of the bay, 0.25 mi east-southeast of the Sampson and Pender County line, in southeastern 1/9th of map area (latitude $34.6663^{\circ} \mathrm{N}$., longitude $78.1619^{\circ} \mathrm{W}$.). Surface elevation $85 \mathrm{ft}$.

\section{LITHOLOGY}

DEPTH IN FEET

\section{Dune sand}

Obtained subsurface sample of sand from rim at southeastern end of

Gap Bay for optically stimulated thermoluminescence (OSL) dating.

Sample yielded quartz blue-light OSL age of 8,575 $\pm 1,420$ years B.P.

(Shannon Mahan, USGS, written commun., 2005). 
HA-7-04: $6.03 \mathrm{mi}$ west of eastern quadrangle border, $1.63 \mathrm{mi}$ north of southern quadrangle border, on northeastern side of unnumbered road, $0.1 \mathrm{mi}$ southeast of junction of that road with North Carolina State Road 1100, 0.55 mi southsouthwest of Royal Chapel, in southwestern $1 / 9$ th of map area (latitude $34.6487^{\circ} \mathrm{N}$., longitude $78.2302^{\circ} \mathrm{W}$.). Surface elevation $64 \mathrm{ft}$.

\section{LITHOLOGY}

DEPTH, IN FEET

\section{Charles City Formation}

Sand, fine to medium, silty; dark yellowish brown

(10YR 4/2) over light yellowish brown (10YR 6/4)

Sand, fine, silty; dusky yellowish orange (10YR 5/6)

grading at $4 \mathrm{ft}$ to yellowish gray ( $5 Y$ 8/1).

Sand, fine to medium, silty, dark-yellowish-orange

(10YR 6/6)

Sand, medium to coarse, silty, pale-yellowish-brown

(10YR 7/2); lower contact abrupt

\section{UNCONFORMITY}

\section{Windsor Formation}

Sand, very fine to fine, silty; dusky yellowish orange

(10YR 5/6) with light-olive gray ( $5 Y$ 5/2) mottles; cemented

in top 1 in.

Sand, fine, silty, soft, thixotropic; yellowish orange

(10YR 7/6) grading down to dark greenish yellow

$(10 Y$ 6/4)

Silt, sandy (very fine), slightly clayey, olive-gray

( $5 Y 4 / 2$ ); grades down to fine, slightly silty,

dark-greenish-gray (5GY 4/1) sand.

Sand, very fine, clayey, dark-greenish-gray ( $5 G Y$ 4/1);

sparse wood fragments.

Coquina; cemented shell fragments; very hard; greenish

gray $(5 G 6 / 1)$.

Sand, fine to medium, very shelly, dark-greenish-gray

(5GY 4/1).

\section{UNCONFORMITY}

\section{Tar Heel Formation(?)}

Impenetrable hard bed. at 53

Base of Charles City Formation:

Base of Windsor Formation:

\section{Bottomed on Tar Heel Formation?}

$+51 \mathrm{ft}$ above sea level

$+11 \mathrm{ft}$ above sea level 
HA-8-04: $6.80 \mathrm{mi}$ west of eastern quadrangle border, $8.20 \mathrm{mi}$ north of southern quadrangle border, on northwestern side of dirt road, $0.2 \mathrm{mi}$ northeast of $146-\mathrm{ft}$ spot elevation, $0.5 \mathrm{mi}$ southeast of northwestern corner of quadrangle, in northwestern 1/9th of map area (latitude $34.7442^{\circ} \mathrm{N}$., longitude $78.2437^{\circ} \mathrm{W}$.). Surface elevation $146 \mathrm{ft}$.

\section{LITHOLOGY}

DEPTH, IN FEET

\section{Dune sand}

Sand, fine, well-sorted; pale yellowish brown (10YR 6/2)

grading down to pale grayish orange $(10 Y R$ 8/4).

Sand, fine, well-sorted; dark yellow (5Y 7/4) grading

down to yellowish gray (5Y 8/1)

Sand, fine, slightly clayey and silty; denser than interval above;

yellowish gray $(5 Y$ 8/1)....

Sand; fine grading down to fine to medium; very pale yellowish brown (10YR 7/2)

\section{UNCONFORMITY}

\section{Waccamaw Formation, Bahramsville unit}

Sand, medium to coarse, pale-grayish-orange (10YR 8/4);

lower contact gradational.

Sand; coarse to very coarse, with quartz granules and

small pebbles up to $1 \mathrm{~cm}$ in diameter; yellowish orange

(10YR 7/6) grading down to yellowish gray $(5 Y 8 / 1)$ at $41 \mathrm{ft}$

\section{Tar Heel Formation}

Sand, very fine to fine, silty, clayey; pale grayish orange

(10YR 7/4) grading down through dark yellowish gray

(5Y 7/2) to dark yellowish orange (10YR 6/6).

Silt, very clayey, dense, dark-greenish-gray (5GY 3/1); interbedded with thin layers of very fine to fine sand;

micaceous; locally abundant lignite..... $61-76$

Base of dune sand:

Base of Waccamaw Formation, Bahramsville unit:
$+118 \mathrm{ft}$ above sea level

$+89 \mathrm{ft}$ above sea level

\section{Bottomed in Tar Heel Formation}




\section{Hope Mills Quadrangle}

HM-1-07: 4.19 mi west of eastern quadrangle border, $1.97 \mathrm{mi}$ north of southern quadrangle border, on northwestern side of North Carolina State Road 1718, $0.68 \mathrm{mi}$ west of North Carolina State Road 1718 overpass over Interstate 95, in south-central $1 / 9$ th of map area (latitude $34.9033^{\circ} \mathrm{N}$., longitude $78.9463^{\circ} \mathrm{W}$.). Surface elevation $167 \mathrm{ft}$.

\section{LITHOLOGY}

DEPTH, IN FEET

\section{Dune sand}

Sand, very fine to fine, silty; brownish gray (5YR 4/1) grading down to dusky yellowish orange $(10 Y R 5 / 6)$

Sand, very fine to medium, poorly sorted, silty; dusky yellowish orange $(10 Y R 5 / 6)$ grading down to pale yellowish brown (10YR 6/2)

\section{UNCONFORMITY}

\section{Varina Grove unit}

Sand, fine to coarse, poorly sorted, subangular to angular, silty; pale yellowish brown (10YR 6/2) grading down

to very pale orange $(10 Y R$ 8/2)

Sand; medium to coarse grading down to medium to very coarse; light pink (5R 8/4); scattered rounded and polished quartz pebbles up to $3 \mathrm{~cm}$ in diameter

\section{UNCONFORMITY}

\section{Tar Heel Formation}

Clay, silty, dense, sticky; weathered to grayish orange

(10YR 7/4) with pale-yellowish-brown (10YR 6/2)

and dark-yellowish-orange (10YR 6/6) mottles;

lower contact somewhat gradational

Base of dune sand:

Base of Varina Grove unit:

\section{Bottomed in Tar Heel Formation}

$+161 \mathrm{ft}$ above sea level

$+145 \mathrm{ft}$ above sea level 
HM-2-07: $6.40 \mathrm{mi}$ west of eastern quadrangle border, $4.56 \mathrm{mi}$ north of southern quadrangle border, on western rim of a Carolina bay, $0.07 \mathrm{mi}$ southeast of North Carolina State Road 1115 and 0.27 mi northeast of intersection of North Carolina State Road 1115 and 1116, in west-central 1/9th of map area (latitude $34.9412^{\circ} \mathrm{N}$., longitude $78.9872^{\circ} \mathrm{W}$.). Surface elevation $190 \mathrm{ft}$.

\section{LITHOLOGY}

DEPTH, IN FEET

\section{Dune sand}

Sand, medium to coarse, slightly silty; dark yellowish orange

(10YR 6/6) grading down to dusky yellowish orange (10YR 5/6)

Sand; dominantly fine but up to medium; silty; clayey; grayish

orange pink (5YR 6/2) with dark-reddish-brown (5YR 3/4) streaks

grading down to pale yellowish brown (10YR 6/2).

Sand, medium to coarse, silty, sticky; medium pinkish gray

(5YR 7/1) grading down to pale yellowish orange (10YR 8/6)

in basal 3 in.; lower contact abrupt

Sand, very fine, clayey, silty, dense, stiff, very light gray

$(N$ 8); tough drilling

Sand, very fine, clean, slightly silty, pale-orange (10YR 8/8);

much softer than interval above

UNCONFORMITY

\section{Varina Grove unit}

Sand, fine to medium, subangular to angular, silty; yellowish orange (10YR 7/6) grading down to pale grayish orange $(10 Y R 8 / 4)$ at $12 \mathrm{ft}$

Sand, fine to medium, subangular to angular, kaolinitic, yellowish-gray (5Y 8/1); occasional quartz granules and pebbles including a 2-cm-long discoid; silty clayballs

between 30 and $31 \mathrm{ft}$...

Sand, fine to medium grading down to medium to coarse; permeable; dark orange (10YR 6/8) grading down to yellowish orange (10YR 7/6) at $36 \mathrm{ft}$.

Clay, silty, sticky, dense; medium yellowish brown (10YR 5/4) with medium-red (5R 4/6) mottles.

Sand, fine to medium, silty, slightly clayey, dark-orange (10YR 6/8)

Sand, medium to very coarse, poorly sorted, slightly silty, transmissive, dark-red (5R 3/6) 


\section{Tar Heel Formation}

Sand, fine, micaceous, orange (10YR 7/8) ..... $49-49.5$

Clay, silty, light-yellowish-brown (10YR 6/4) $49.5-50$

Sand, fine, micaceous, dark-reddish-brown (10R 3/4). $50-61$

Base of dune sand:

$+179 \mathrm{ft}$ above sea level

Base of Varina Grove unit:

$+141 \mathrm{ft}$ above sea level

\section{Bottomed in Tar Heel Formation}


HM-3-07: $2.02 \mathrm{mi}$ west of eastern quadrangle border, $4.50 \mathrm{mi}$ north of southern quadrangle border, on eastern side of unnumbered dirt road, $0.73 \mathrm{mi}$ east-northeast of North Carolina State Road 2252 overpass over Interstate 95, in eastcentral 1/9th of map area (latitude $34.9403^{\circ} \mathrm{N}$., longitude $78.9102^{\circ} \mathrm{W}$.). Surface elevation $163 \mathrm{ft}$.

\section{LITHOLOGY}

DEPTH, IN FEET

\section{Dune sand}

Sand; dominantly fine but up to medium grained; clean;

soft, grayish orange (10YR 7/4).

Sand; dominantly fine but up to medium grained;

slightly silty; dark yellowish orange (10YR 6/6)

Sand; dominantly fine but up to medium-grained; clean;

pale grayish orange (10YR 8/4)....

\section{Varina Grove unit}

Sand, fine grading down to fine to medium; clayey; silty;

light brown (5YR 6/6) grading down to light olive gray

(5Y 6/1) with medium-reddish-brown (10R 4/8) mottles at $9 \mathrm{ft}$;

tough drilling.

Sand, fine to medium, clayey, silty, subangular to angular, pale-brown (5YR 5/2); tough drilling

Sand, medium to coarse, silty; reddish brown (10R 6/8)

grading down through pale reddish brown (10R 5/6) (17-18 ft)

to dark red $(5 R 3 / 6)$

Sand, fine to medium, silty; yellowish orange (10YR 7/6)

grading to grayish orange pink (5YR 7/2) at $20 \mathrm{ft}$; 1 -in.-thick,

pale-grayish-orange (10YR 8/4) layer at base with subrounded

to rounded quartz pebbles up to $3 \mathrm{~cm}$ in diameter

\section{UNCONFORMITY}

\section{Tar Heel Formation}

Clay, silty, tough; top 6 in. weathered to medium yellowish brown (10YR 5/4) then grades to dark brownish gray $(5 Y R 3 / 1)$...

Base of dune sand:

Base of Varina Grove unit:

\section{Bottomed in Tar Heel Formation}

$+157 \mathrm{ft}$ above sea level

$+141 \mathrm{ft}$ above sea level 
HM-4-07: $3.59 \mathrm{mi}$ west of eastern quadrangle border, $8.29 \mathrm{mi}$ north of southern quadrangle border, on western side of CSX Railroad cut at top of bluff, $0.37 \mathrm{mi}$ along railroad from top border of quadrangle, in north-central 1/9th of map area (latitude $34.9957^{\circ} \mathrm{N}$., longitude $78.9380^{\circ} \mathrm{W}$.). Surface elevation $188 \mathrm{ft}$.

\section{LITHOLOGY}

DEPTH, IN FEET

\section{Dune sand}

Sand, very fine to fine, slightly silty, grayish-orange (10YR 7/4)

Sand, very fine to fine, slightly silty, dark-yellowish orange $(10 Y R 6 / 6)$

Sand, very fine to fine, clean; pale grayish orange (10YR 8/4)

grading down to very pale grayish orange (10YR 9/4) at $6 \mathrm{ft}$.

\section{UNCONFORMITY}

\section{Chowan River Formation, Coharie Member}

Sand, fine to medium, silty, clayey; dark yellowish orange

(10YR 6/6) grading down through light yellowish brown (10YR 6/4)

to medium yellowish brown (10YR 5/4); contains rounded

quartz pebbles up to $1 \mathrm{~cm}$ in diameter

Sand, fine to medium, soft, clean, pale-yellowish-gray

(5Y 9/1); possible filled paleo-groundhog burrow

Sand, very fine to dominantly fine, silty, clayey; sparse

fine mica flakes; dark yellowish brown (10YR 4/2);

lower contact gradational

Sand; very fine to fine grading down to fine to medium;

silty; slightly clayey; micaceous; grayish orange (10YR 7/4)

Silt, clayey, sandy (very fine); yellowish orange (10YR 7/6)

grading down rapidly to pale yellowish brown (10YR 6/2).

Sand; medium to coarse grading down to medium to very coarse; silty; soft; dark yellow (5Y 6/6)

Sand, fine to medium, silty, soft; pale yellowish gray

$(5 Y 8 / 2)$ grading down at $34 \mathrm{ft}$ to white $(N 8)$; very

kaolinitic; abundant large mica flakes.

Sand; medium to coarse grading down in basal foot to medium to very coarse; poorly sorted, with subangular to subrounded quartz pebbles up to $1 \mathrm{~cm}$ in diameter; slightly silty; soft; yellowish orange (10YR 7/6) 


\section{Tar Heel Formation}

Clay, silty, dense, dark-gray ( $N$ 3); medium-light-gray ( $N$ 6), clean, very fine quartz-sand laminae and scattered pyrite lumps

Base of dune sand:

Base of Chowan River Formation, Coharie Member:

$+180 \mathrm{ft}$ above sea level

$+144 \mathrm{ft}$ above sea level

\section{Bottomed in Tar Heel Formation}




\section{Ingold Quadrangle}

IG-1-05: 3.39 mi west of eastern quadrangle border, $6.58 \mathrm{mi}$ north of southern quadrangle border, behind abandoned house on northeastern side of North Carolina State Road 1004, 1.75 mi west-southwest of Union School, in northcentral 1/9th of map area (latitude $34.8455^{\circ} \mathrm{N}$., longitude $78.3093^{\circ} \mathrm{W}$.). Surface elevation $130 \mathrm{ft}$.

\section{LITHOLOGY}

DEPTH, IN FEET

\section{Waccamaw Formation, Bahramsville unit}

Sand, fine to medium, silty; very dark yellowish brown

(10YR 3/2) grading down through light yellowish brown

(10YR 6/4) to dusky yellowish orange (10YR 5/6)

Sand, fine to medium, silty, sparsely granular and pebbly,

dusky-yellowish-orange (10YR 5/6); lower contact gradational

Sand, fine, silty, medium-reddish-brown (10R 4/6)...

Sand, very fine to fine, silty, clayey, dense, medium-light-

gray $(N 6)$

Silt, very clayey, dense, pale-olive-gray (5Y 7/1)

Sand, fine to coarse, poorly sorted, light-brown (5YR 5/6);

sparse quartz granules and pebbles up to $0.7 \mathrm{~cm}$ in diameter

Silt, very clayey, sandy (very fine), pale-brown (5YR 6/6)

Sand, fine to coarse, poorly sorted, silty, soft, thixotropic;

pale grayish orange (10YR $8 / 4)$ grading down to yellowish

white (5Y 9/1)

Silt, sandy (very fine); pale yellowish orange (10YR 8/6) with

medium-reddish-orange $(10 R$ 6/6) streaks

Sand, medium to very coarse, poorly sorted, silty, yellowish-

orange $(10 Y R 7 / 6)$.

Silt, clayey; pale yellowish orange (10YR 8/6) with

medium-reddish-orange $(10 R$ 6/6) streaks

Sand, fine to coarse, poorly sorted, silty, yellowish-orange (10YR 7/6); abundant quartz pebbles up to $1 \mathrm{~cm}$ in diameter at base

UNCONFORMITY

\section{Chowan River Formation, Coharie Member}

Sand, fine, well-sorted, thixotropic; reddish orange (10R 5/6)

grading down to pale yellow (5Y 8/6)

Silt, very clayey, dense; pale olive gray (5Y 6/2) with darkreddish-brown (10R 3/4) mottles grading down to dark olive gray $(5 Y 3 / 1)$ 
Sand; fine grading down to fine to medium; silty; light olive brown $(5 Y 5 / 4)$

Sand, fine, silty, slightly clayey, yellowish-orange (10YR 7/6) $56-58$

Sand, fine to medium, silty, light-olive-brown (5Y 5/4) $58-61$

\section{UNCONFORMITY}

\section{Tar Heel Formation}

Silt, micaceous, clayey, sandy (very fine), very lignitic, medium-greenish-gray (5G 5/1) $61-62$

Sand; fine to coarse, dominantly medium; pale grayish orange $(10 Y R$ 8/4) $62-65.5$

Silt, medium-greenish-gray (5G 5/1) $65.5-66$

Base of Waccamaw Formation, Bahramsville unit: Base of Chowan River Formation, Coharie Member:
$+97 \mathrm{ft}$ above sea level +69 ft above sea level

\section{Bottomed in Tar Heel Formation}


IG-2-05: $1.17 \mathrm{mi}$ west of eastern quadrangle border, $3.67 \mathrm{mi}$ north of southern quadrangle border, on hillcrest north of North Carolina State Road 1003, 0.25 mi north of Salem Church, in east-central 1/9th of map area (latitude $34.8033^{\circ} \mathrm{N}$., longitude $78.2700^{\circ} \mathrm{W}$.). Surface elevation $142 \mathrm{ft}$.

\section{LITHOLOGY}

DEPTH, IN FEET

\section{Dune sand}

Sand, fine, clean, soft; yellowish brown (10YR 4/2)

grading down to pale grayish orange (10YR $8 / 4)$.

Sand, fine to medium, subangular; dusky yellowish orange (10YR 5/6) grading down through pale grayish orange (10YR $8 / 4)(4-10 \mathrm{ft})$ and very pale orange $(10 Y R$ 8/2) (10-12 ft) to grayish brown (5YR 3/2).....

\section{UNCONFORMITY}

\section{Waccamaw Formation, Bahramsville unit}

Sand, fine, silty, clayey; light brown (5YR 4/2) grading down to pale yellowish brown (10YR 6/2); denser than unit above.

Silt, very clayey, dense and stiff; yellowish gray (5Y 8/1) with pale-grayish-orange (10YR 8/4) and pale-brown (5YR 6/6) streaks

Sand, fine to medium, silty, finely micaceous; yellowish orange (10YR 7/6) grading down to yellowish gray $(5 Y 8 / 1)$

Sand; fine to medium, dominantly medium; slightly silty; light orange (10YR 7/2) grading down to yellowish gray $(5 Y 8 / 1)$

Sand, medium to coarse, silty, yellowish-gray (5Y 8/1); scattered clayballs and quartz granules, lower contact somewhat gradational

Sand, medium to very coarse, poorly sorted, slightly silty, dark-yellowish-orange (10YR 6/6); lower contact abrupt

\section{UNCONFORMITY}

\section{Chowan River Formation, Coharie Member}

Sand; fine grading down though fine to medium to medium to coarse; thin, clayey silt layers at $46 \mathrm{ft}$ and $48 \mathrm{ft}$; dark-yellowish-orange (10YR 6/8) sand and yellowish-gray (5Y 7/2), clayey silt layers with light-brown (5YR 5/6) streaks 


\section{Tar Heel Formation}

Sand, very fine to fine, silty, yellowish-gray ( $5 Y 7 / 2)$; thin

interbeds of very lignitic, yellowish orange (5YR 7/6), fine sand,

$50-51$

Base of dune sands:

Base of Waccamaw Formation, Bahramsville unit:

Base of Chowan River, Formation, Coharie Member:

$+124 \mathrm{ft}$ above sea level $+98 \mathrm{ft}$ above sea level $+92 \mathrm{ft}$ above sea level

Bottomed in Tar Heel Formation 
IG-3-05: $4.19 \mathrm{mi}$ west of eastern quadrangle border, $0.95 \mathrm{mi}$ north of southern quadrangle border, on eastern side of North Carolina State Highway 411, in south-central 1/9th of map area (latitude $34.7638^{\circ} \mathrm{N}$., longitude $78.3230^{\circ} \mathrm{W}$.). Surface elevation $65 \mathrm{ft}$.

\section{LITHOLOGY}

DEPTH, IN FEET

\section{Charles City Formation}

Sand, fine to medium, clean, soft; yellowish brown $(10 Y R 5 / 2)$ grading down to pale grayish orange $(10 Y R$ 8/4)

Sand, fine to medium, clean, soft; dark yellowish orange (10YR 6/6) grading down to pale yellowish brown (10YR 6/2); abundant subrounded to rounded quartz pebbles up to $3 \mathrm{~cm}$ in diameter in basal foot

\section{Tar Heel Formation}

Sand; very fine to fine interbedded with sandy (very fine) silt; dense; silt intervals sticky; yellowish orange (10YR 7/6) with yellowish-gray $(5 Y 7 / 2)$ mottles

Silt, very clayey, stiff, dense, dark-greenish-gray (5GY 3/1) $11-12$

Sand, very fine to fine, silty, clayey, very micaceous, darkgreenish-gray (5GY 3/1)

Sand, fine to medium, micaceous, lignitic, mediumgreenish-gray (5GY 5/1)

Silt, very clayey, massive, dense, lignitic, dark-greenishgray $(5 G Y 3 / 1)$

Base of Charles City Formation:

Bottomed in Tar Heel Formation 
IG-4-05: $6.87 \mathrm{mi}$ west of eastern quadrangle border, $3.20 \mathrm{mi}$ north of southern quadrangle border, on southern side of North Carolina State Road 1135, 0.25 mi east of western quadrangle border, in west-central 1/9th of map area (latitude $34.7967^{\circ} \mathrm{N}$., longitude $78.3700^{\circ} \mathrm{W}$.). Surface elevation

$75 \mathrm{ft}$.

LITHOLOGY

DEPTH, IN FEET

\section{Charles City Formation}

Sand, fine to coarse, subangular to subrounded, poorly

sorted, clean; pale yellowish brown (10YR 6/2)

grading down to pale grayish orange (10YR $8 / 4)$.

Sand, fine to coarse, poorly sorted, grayish-brown

(5YR 3/2); contains subrounded quartz pebbles up

to $1 \mathrm{~cm}$ in diameter

Sand, fine to medium, clayey, silty, sticky; denser

than interval above; pale yellowish brown (10YR 6/2)

Sand, fine, silty; softer than interval above; dark yellowish

brown (10YR 4/2); lower contact somewhat gradational

Gravel; quartz pebbles up to $1 \mathrm{~cm}$ in diameter in a matrix of coarse to very coarse sand; dark yellowish

brown $(10 Y R 4 / 2)$

\section{UNCONFORMITY}

\section{Tar Heel Formation}

Sand, very fine to fine, silty, clayey, micaceous; grayish olive (10Y 4/2) grading rapidly down to dark greenish gray (5GY 4/1)

Base of Charles City Formation:

+57 ft above sea level

\section{Bottomed in Tar Heel Formation}


IG-5-08: $3.72 \mathrm{mi}$ west of eastern quadrangle border, $8.14 \mathrm{mi}$ north of southern quadrangle border, on northeastern side of North Carolina State Road 1141, 0.21 mi west of intersection with North Carolina State Road 1142, in north-central 1/9th of map area (latitude $34.8681^{\circ} \mathrm{N}$., longitude $78.3145^{\circ} \mathrm{W}$.). Surface elevation $146 \mathrm{ft}$.

\section{LITHOLOGY}

DEPTH, IN FEET

\section{Dune sand}

Sand, fine to medium, angular to subangular, silty; medium yellowish brown (10YR 5/4) over dark yellowish orange (10YR 6/6) (4-12 in.).

Sand, fine to medium, angular to subangular, slightly silty, soft; dark yellowish orange (10YR 6/6) grading down through pale grayish orange (10YR 8/4) (2-5 ft), light yellowish brown (10YR 6/4) (5-7 ft), and pale yellowish brown $(10 Y R$ 7/6) (7-8 ft) to yellowish brown (10YR 5/2)......

\section{UNCONFORMITY}

\section{Waccamaw Formation, Bahramsville unit}

Sand, fine, silty, pale-yellowish-brown (10YR 6/2);

stiffer than unit above; lower contact somewhat gradational

Sand, very fine to fine, very silty, slightly clayey; very fine mica flakes; yellowish brown (10YR 5/2)

Sand, fine, very clayey and silty, stiff, slightly sticky, yellowish-brown (10YR 5/2); lower contact gradational

Sand, fine, very silty, pale-pinkish-gray (5YR 9/1);

lower contact gradational.

Sand, fine to coarse, poorly sorted, silty, yellowishorange (10YR 7/6); lower contact rapidly gradational.

Sand, medium to very coarse, subangular to angular, poorly sorted; less than 1 percent very fine, dark, heavy minerals; slightly silty; transmissive; yellowish orange (10YR 7/6) grading down to yellowish gray (5Y 8/1)....

\section{Bottomed in Waccamaw Formation, Bahramsville unit}




\section{Jerome Quadrangle}

JE-1-07: $0.82 \mathrm{mi}$ west of eastern quadrangle border, $7.36 \mathrm{mi}$ north of southern quadrangle border, on southern side of unnumbered road $100 \mathrm{ft}$ west of intersection with North Carolina State Road 1002, $0.1 \mathrm{mi}$ northwest of China Grove Church, in northeastern 1/9th of map area (latitude $34.8567^{\circ} \mathrm{N}$., longitude $78.6393^{\circ} \mathrm{W}$.). Surface elevation $118 \mathrm{ft}$.

\section{LITHOLOGY}

DEPTH, IN FEET

\section{Dune sand}

Sand, fine to medium, slightly silty, soft; dusky yellowish

orange $(10 Y R 4 / 2)$ grading down through pale orange $(10 Y R 7 / 2)$

(0.5-1.5 ft) to dark yellowish orange (10YR 6/6).

Sand, fine to medium, silty; dark yellowish orange (10YR 6/6)

grading down through light brown (5YR 5/6) and grayish

orange (10YR 7/4) to grayish orange pink (5YR 7/2)

Sand; fine to medium, dominantly fine; slightly silty; softer

than interval above; very light gray $(N 8)$; lower contact abrupt.

\section{Windsor Formation}

Silt, very clayey, dense, stiff, orange-pink (5YR 7/4). $11-12$

Silt, very clayey, sandy (fine to medium), dense, very stiff;

light gray $(N 7)$ with grayish-orange (10YR 7/4) mottles...

Sand, medium to coarse, angular to subangular, very clayey

and silty, yellowish-orange (10YR 7/6); lower contact gradational.

Sand, medium to coarse, angular to subangular, clayey,

silty, orange (10YR 7/8)

Sand, medium to coarse, slightly silty, transmissive, yellowish-gray ( $5 Y$ 8/1); lower contact gradational

Sand, medium to very coarse, poorly sorted; quartz granules abundant in basal 3 in.; pale orange (10YR 8/8) mingled with orange (10YR 8/7)

\section{Tar Heel Formation}

Clay, sticky, stiff; abundant fine mica flakes; dark gray $(N 3)$.....

Base of dune sand:

Base of Windsor Formation:

$+107 \mathrm{ft}$ above sea level $+85 \mathrm{ft}$ above sea level

\section{Bottomed in Tar Heel Formation}


JE-2-07: $1.36 \mathrm{mi}$ west of eastern quadrangle border, $7.35 \mathrm{mi}$ north of southern quadrangle border, in field $0.11 \mathrm{mi}$ northeast of unnumbered road, 1.0 mi west of intersection of unnumbered road with North Carolina State Road 1002 (intersection located 0.1 mi northwest of China Grove Church), in northeastern 1/9th of map area (latitude $34.8565^{\circ} \mathrm{N}$., longitude $78.6483^{\circ} \mathrm{W}$.). Surface elevation

$102 \mathrm{ft}$.

\section{LITHOLOGY}

DEPTH, IN FEET

\section{Windsor Formation}

Sand, fine to medium, slightly silty, soft; grayish brown

(5YR 3/2) grading down through grayish orange (10YR 7/4)

and dusky yellowish orange (10YR 5/6) to

yellowish orange (10YR 7/6)

Sand, fine to medium, silty, slightly clayey; grades down to

fine, very clayey, and silty; light yellowish brown (10YR 6/4)

Sand, fine to medium, silty, soft, medium-yellowish-

brown (10YR 5/4); lower contact gradational

Sand, medium to very coarse, poorly sorted, silty, soft,

medium-yellowish-brown (10YR 5/4); lower contact gradational

Sand, fine to medium, silty, soft, medium-yellowish-

brown (10YR 5/4); lower contact gradational

Sand, medium to very coarse, poorly sorted, soft, light-olive-

gray (5Y 6/1); abundant subrounded quartz pebbles

up to $3 \mathrm{~cm}$ in diameter; silty and clayey in basal foot

\section{UNCONFORMITY}

\section{Tar Heel Formation}

Clay, silty, stiff, dense; abundant fine mica

flakes; dark olive gray (5Y 3/1).

Sand, fine, silty, slightly clayey, medium-olive-gray

(5Y 3/2); fine to coarse mica flakes and scattered

wood clasts; interbedded with dense clay layers.

\section{Bottomed in Tar Heel Formation}


JE-3-07: $6.23 \mathrm{mi}$ west of eastern quadrangle border, $6.60 \mathrm{mi}$ north of southern quadrangle border, on eastern side of North Carolina Highway 53, 0.20 mi north of Jerome and $0.88 \mathrm{mi}$ north of intersection with North Carolina State Road 1327 , in northwestern $1 / 9$ th of map area (latitude $34.8462^{\circ} \mathrm{N}$., longitude $78.7340^{\circ} \mathrm{W}$.). Surface elevation $104 \mathrm{ft}$.

\section{LITHOLOGY}

DEPTH, IN FEET

\section{Dune sand}

Sand, fine to medium, dominantly fine, soft; dark yellowish brown $(10 Y R$ 4/2) grading down to grayish orange (10YR 7/6).

Sand, fine to medium, dominantly fine, soft; yellowish orange $(10 Y R$ 7/6) grading down through yellowish gray (5Y 8/1) (6-9 ft) and grayish orange pink (5YR 7/2) $(9-10 \mathrm{ft})$ to very pale orange $(10 Y R \mathrm{8} / 2)$...

\section{Windsor Formation}

Sand, very fine, silty, clayey, moderately stiff, darkbrownish-gray (5YR 3/1)

Sand, fine; dark yellowish brown (10YR 3/2) grading down to grayish orange (10YR 7.5/4) at about $22 \mathrm{ft}$; root fragments

Silt, clayey, sandy (very fine), stiff; grades down to very fine to fine, silty, clayey sand; pale orange (10YR 7/2) in upper foot grading rapidly down to pale olive gray $(5 Y 7 / 1)$.....

Sand; fine to medium grading down to medium to coarse; pale olive gray ( $5 Y 7 / 1)$; rounded to subrounded quartz pebbles up to $1 \mathrm{~cm}$ in diameter; lower contact gradational

Sand, coarse to very coarse, pale-olive-gray ( $5 Y 7 / 1)$; abundant subangular to subrounded quartz granules

\section{UNCONFORMITY}

\section{Tar Heel Formation}

Clay, silty, dense; abundant fine mica

flakes; dark olive gray (5Y 3/1).

Base of dune sand:

Base of Windsor Formation:

\section{Bottomed in Tar Heel Formation}

$+88 \mathrm{ft}$ above sea level $+66 \mathrm{ft}$ above sea level 
JE-4-07: $3.23 \mathrm{mi}$ west of eastern quadrangle border, $3.69 \mathrm{mi}$ north of southern quadrangle border, on northeastern side of North Carolina State Road 1327, 1.57 mi northwest of intersection with North Carolina State Road 1325, in central 1/9th of map area (latitude $34.8037^{\circ} \mathrm{N}$., longitude $78.6812^{\circ} \mathrm{W}$.). Surface elevation $101 \mathrm{ft}$.

\section{LITHOLOGY}

DEPTH, IN FEET

\section{Dune sand}

Sand; fine to medium, dominantly fine; slightly

silty; grayish orange (10YR 7/4) grading down to

dark yellowish orange (10YR 6/6).

Sand; fine to medium, dominantly fine; soft;

yellowish gray (5Y 9/1) grading down through very pale

yellowish brown (10YR 7/2) with dark-orange

(10YR 6/8) mottles (2-3 ft) to pale pinkish gray (5YR 9/1).

Sand; fine to medium, dominantly fine; soft; slightly

humic; medium yellowish brown (10YR 5/4);

lower contact abrupt

\section{UNCONFORMITY}

\section{Charles City Formation}

Silt, sandy (very fine), clayey, micaceous; top 3 in.

light olive gray ( $5 Y 6 / 1$ ), grades down to grayish brown

(5YR 3/2)

Sand, fine to medium, silty, yellowish-brown (10YR 5/2);

lower contact gradational.

Sand; fine to coarse with coarse fraction subrounded;

poorly sorted; slightly silty; yellowish gray ( $5 Y 7 / 2)$; grades

down to sand, medium to very coarse and granular;

granules subangular to subrounded, very pale yellowish

brown (10YR 7/2); kaolin ghosts of feldspar

crystals in basal $2 \mathrm{ft}$.

Sand, medium to very coarse, granular, poorly sorted, slightly kaolinitic, transmissive, yellowish-gray

(5Y 7/1); sparse coarse, silvery mica; less

than 1 percent very fine, dark, heavy minerals; about

10 percent of granular fraction composed of white feldspar.

\section{UNCONFORMITY}

\section{Windsor(?) Formation}

Silt, very clayey, sandy (very fine), finely micaceous, greenish-gray ( $5 G 6 / 1$ ); lower contact gradational.

Sand, very fine to fine, silty, variably clayey;

abundant coarse, silvery mica; greenish gray (5GY 6/1) 
Sand, medium to very coarse, subangular, poorly sorted, pale-olive-gray (5Y 7/1); abundant subrounded

to rounded quartz pebbles up to $3 \mathrm{~cm}$ in diameter

$67-71$

Base of dune sand:

Base of Charles City Formation:

$+79 \mathrm{ft}$ above sea level

$+57 \mathrm{ft}$ above sea level

Bottomed in Windsor Formation (?) 
JE-5-07: $0.67 \mathrm{mi}$ west of eastern quadrangle border, $1.83 \mathrm{mi}$ north of southern quadrangle border, $200 \mathrm{ft}$ northeast of North Carolina State Road 1325, 0.45 mi west-northwest of 103-ft elevation benchmark station, in southeastern 1/9th of map area (latitude $34.7769^{\circ} \mathrm{N}$., longitude $78.6367^{\circ} \mathrm{W}$.). Surface elevation $100 \mathrm{ft}$.

\section{LITHOLOGY}

DEPTH, IN FEET

\section{Dune sand}

Sand, fine, silty; dusky yellowish brown (10YR 2/2)

grading down through dark yellow (5Y 6/6) to

light yellowish brown $(10 Y R$ 6/4) $(1-3 \mathrm{ft})$......

Sand, fine, clean, soft, pinkish-gray (5YR 8/1)

Sand, fine to medium, humic, soft; pale grayish orange

(10YR 8/4) grading down to very dark yellowish

brown (10YR 3/2) in basal foot

\section{UNCONFORMITY}

\section{Windsor Formation}

Sand, fine, silty, clayey, pale-yellowish-brown (10YR 6/2); much denser than unit above

Sand; fine to medium grading down to medium to very coarse; poorly sorted; slightly silty; pale yellowish gray (5Y 8/2) grading down to medium olive gray $(5 Y 5 / 1)$

\section{UNCONFORMITY}

\section{Tar Heel Formation}

Sand, fine, silty, clayey, micaceous, dark-brownishgray (5YR 3/1) to olive-gray (5Y 4/1); numerous

clasts of wood

Peat, dark-brownish-gray (5YR 3/1).....

Sand, fine, silty, clayey, micaceous, dark-brownishgray (5YR 3/1) to olive-gray (5Y 4/1); sparse clasts of wood; silt and clay content decreases downward.

Sand, fine, slightly silty, micaceous; dark greenish gray $(5 G 3 / 1)$ grading down to dark greenish gray (5GY 3/1); scattered clasts of wood; increasingly silty and clayey downward

Clay, silty, dense, dusky-greenish-gray (5GY 3/1);

laminae of clean, very fine, angular, olive (10Y 5/2) sand, $52-53$ 
Sand, fine, silty, clayey, micaceous, dusky-greenish-gray

(5GY 3/1); abundant wood fragments

Base of dune sand:

$+88 \mathrm{ft}$ above sea level

Base of Windsor Formation:

$+78 \mathrm{ft}$ above sea level

Bottomed in Tar Heel Formation 
JE-6-07: $5.19 \mathrm{mi}$ west of eastern quadrangle border, $1.40 \mathrm{mi}$ north of southern quadrangle border, on northeastern side of North Carolina Highway 53, $0.47 \mathrm{mi}$ north-northeast of 82-ft benchmark station, in southwest 1/9th of map area (latitude $34.7704^{\circ} \mathrm{N}$., longitude $78.7157^{\circ} \mathrm{W}$.). Surface elevation $83 \mathrm{ft}$.

\section{LITHOLOGY}

DEPTH, IN FEET

\section{Dune sand}

Sand, fine to medium, clean, soft; 1 in. of pale-brown

(5YR $5 / 2)$ topsoil, very pale orange (10YR 8/2) below

Sand, fine to medium, clean, soft; grayish orange

pink $(5 Y R 7 / 2)$ grading down through yellowish orange

$(10 Y R$ 7/6) (3-4 ft) and very pale orange (10YR 8/2)

(4-9 ft) to medium yellow (5Y 7/6)

\section{UNCONFORMITY}

\section{Charles City Formation}

Silt, clayey, sandy (very fine), sticky but not dense; dark brownish gray (5YR 3/1) grading down through light gray $(N 7)(10.5-12 \mathrm{ft})$ to light gray $(N 7)$

with dark-yellow (5Y 6/6) mottles.

Silt, clayey, sandy (very fine), stiff, dense,

finely micaceous; light gray $(N 7)$ with dark-yellow

(5Y 6/6) mottles; grades downward to sand, very

fine to fine, silty, clayey, dark yellow ( $5 Y$ 6/6)

with light-gray $(N 7)$ mottles.

Sand, fine to coarse, subangular to angular, poorly

sorted, clean, pale-yellowish-brown (10YR 6/2);

rounded quartz granules in basal 6 in......

\section{UNCONFORMITY}

\section{Tar Heel Formation}

Clay, silty, dense, dark-brownish-gray (5YR 3/1);

thinly laminated with laminae marked by coarse

mica flakes; sparse black wood fragments...

Base of dune sand:

Base of Charles City Formation:

\section{Bottomed in Tar Heel Formation}

$+73 \mathrm{ft}$ above sea level

$+54 \mathrm{ft}$ above sea level 


\section{Northeast Lumberton Quadrangle}

NL-1-06: $1.78 \mathrm{mi}$ west of eastern quadrangle border, $5.13 \mathrm{mi}$ north of southern quadrangle border, on northern side of drainage ditch and $200 \mathrm{ft}$ southwest of North Carolina State Road 1975, $0.33 \mathrm{mi}$ east of junction of North Carolina State Roads 1975 and 1955, in east-central 1/9th of map area (latitude $34.6996^{\circ} \mathrm{N}$., longitude $78.9061^{\circ} \mathrm{W}$.). Surface elevation $146 \mathrm{ft}$.

\section{LITHOLOGY}

DEPTH, IN FEET

\section{Varina Grove unit}

Sand, fine, slightly silty and clayey; very dark yellowish brown $(10 Y R 3 / 2)$ grading down to medium yellowish brown (10YR 5/4)....

Sand, very fine to fine, silty, clayey, stiff, dense; pale yellowish brown (10YR 6/2) grading down through pale yellowish brown (10YR 6/2) with dark-yellowish-orange (10YR 6/6) mottles (2-4 ft) to pale yellowish brown (10YR 7/2) with dark-yellowish-orange (10YR 6/6) mottles

Sand, very fine, silty, clayey; pale yellowish orange (10YR 8/6) with yellowish-gray (5Y 8/1) streaks ....

Sand; very fine grading down to very fine to fine; silty; yellowish gray $(5 Y 7 / 2)$ grading down to yellowish gray $(5 Y 8 / 1)$.

Sand, fine to medium, silty, light-yellowish-brown (10YR 6/4) $14-18$

Silt, sandy (very fine), very clayey, stiff, sticky; yellowish orange (10YR 7/6) grading down to light olive gray (5Y 6/1)

Sand, fine to medium, light-yellowish-brown

(10YR 6/4).

Silt, sandy (very fine), light-olive-gray (5Y 6/1)

Sand, fine to coarse, poorly sorted, very clayey and silty, bluish-gray (5B 6/1)

\section{Duplin Formation}

Sand, fine to medium, silty, soft, micaceous; light

olive gray $(5 Y 5 / 2)$ grading to medium

light gray $(N 6)$ at $34 \mathrm{ft}$.

Sand, fine to medium, silty, soft, very micaceous,

light-olive-gray (5Y 5/2)..

Sand, fine to medium, silty, soft, micaceous, medium-

light-gray ( $N$ 6) 


\section{Tar Heel Formation}

Silt, very clayey, sandy (very fine), dense, stiff, micaceous; medium olive gray ( $5 Y 5 / 1$ ) grading down to dark brownish gray (5YR 3/1); locally abundant black plant fragments $42-46$

Base of Varina Grove unit:

Base of Duplin Formation:

$+115 \mathrm{ft}$ above sea level

$+104 \mathrm{ft}$ above sea level

Bottomed in Tar Heel Formation 
NL-2-06: $3.88 \mathrm{mi}$ west of eastern quadrangle border, $1.08 \mathrm{mi}$ north of southern quadrangle border, on eastern side of road to cemetery located $0.08 \mathrm{mi}$ south-southeast of North Carolina Highway 41 at junction of North Carolina Highway 41 and North Carolina State Road 1954, in south-central 1/9th of map area (latitude $34.6410^{\circ}$ N., longitude $78.9427^{\circ} \mathrm{W}$.). Surface elevation $158 \mathrm{ft}$.

\section{LITHOLOGY}

DEPTH, IN FEET

\section{Dune sand}

Sand, fine, well-sorted, clean, soft; brownish black (5YR 2/1) grading rapidly to greenish

yellow $(10 Y 7 / 2)$ at 3 in.

Sand, fine, well-sorted, slightly silty and clayey; pale yellowish brown (10YR 6/2) grading down through yellowish gray (5Y 7/1), dusky yellow (5Y 6/4), and grayish orange pink

(5YR 6/2) to light yellowish brown (10YR 6/4)

Peat, sandy (very fine), greenish-black (5GY 1/1); abundant wood fragments*

\section{Varina Grove unit}

Sand; mostly fine but with scattered subrounded medium grains; silty; thixotropic; very dark yellowish orange (10YR 5/6); lower contact gradational

Sand, fine, silty, thixotropic; dark yellowish orange (10YR 6/6) grading down through pale grayish orange (10YR 7/6) (22 to $23 \mathrm{ft})$ to pale yellow (5Y 8/6).

Sand; very fine to fine, dominantly very fine; slightly silty; thixotropic; contains 1-2 percent very fine, dark, heavy minerals; pale yellow (5Y 8/6) grading down through pale orange (10YR 7/2) (29-30 ft), very pale orange (10YR 8/2) (30-40 ft), and yellowish orange (10YR 7/6)

(40-42 ft) to dark yellowish orange (10YR 6/6)...

\section{UNCONFORMITY}

\section{Duplin Formation}

Sand; fine with scattered subrounded to rounded medium grains; very silty; slightly clayey; light olive ( $5 Y 5 / 2)$;

lower contact gradational....

Sand, fine to medium, very silty, slightly clayey; dark greenish gray $(5 G 4 / 2)$ grading down to greenish gray $(5 G Y$ 6/1) at $51 \mathrm{ft}$; lower contact gradational 
Sand, medium to coarse, dark-olive-gray (5Y 4/1);

scattered subrounded to rounded quartz granules

and pebbles up to $0.5 \mathrm{~cm}$ in diameter.

\section{Tar Heel Formation}

Silt, very clayey, sandy (very fine), dense, stiff, very micaceous;

bluish gray (5B 6/1) grading down to light bluish gray (5B 7/1)

Sand; fine to medium with scattered subrounded coarse grains;

feldspathic; slightly silty and clayey; light bluish gray (5B 7/1)

Silt, very clayey, sandy (very fine), dense, stiff, very micaceous,

light-olive-gray (5Y 6/1)...

Base of dune sand:

Base of Varina Grove unit:

Base of Duplin Formation:
$+140 \mathrm{ft}$ above sea level

$+115 \mathrm{ft}$ above sea level

$+101 \mathrm{ft}$ above sea level

\section{Bottomed in Tar Heel Formation}

*Wood fragment at base of peat yielded a radiocarbon age greater than 51,800 B.P.

(John P. McGeehin, USGS, written commun., 2007). 
NL-3-06: 5.33 mi west of eastern quadrangle border, $3.71 \mathrm{mi}$ north of southern quadrangle border, on northeastern side of abandoned house $0.10 \mathrm{mi}$ south-southeast of junction of North Carolina State Roads 1529 and 1947, in westcentral 1/9th of map area (latitude $34.6790^{\circ} \mathrm{N}$., longitude $78.9683^{\circ} \mathrm{W}$.). Surface elevation $139 \mathrm{ft}$.

\section{LITHOLOGY}

DEPTH, IN FEET

\section{Varina Grove unit}

Sand, very fine to fine, yellowish-brown (10YR 5/2)

Peat, sandy (very fine), very dusky red (10R 2/2);

bottoms in pine stump with turpentine odor.

Sand, very fine, clayey, silty, stiff; dusky yellow (5Y 5/4) with pale-reddish-brown (10R 5/6) mottles.

Sand, fine to medium, subangular to subrounded; clayey and silty grading down to silty; pale yellowish gray $(5 Y 8 / 2)$ grading down at $7 \mathrm{ft}$ to bright reddish orange (10R 6/8)

Sand; fine to medium with scattered coarse to very coarse grains; subrounded to subangular; slightly silty; yellowish orange (10YR 7/6)

\section{Duplin Formation}

Sand, fine to medium, silty; light olive brown (5Y 5/6) grading down to grayish yellow (5Y 7/4) at $25 \mathrm{ft}$; shell fragments and lime-cemented nodules

Sand, fine to coarse, poorly sorted, silty; pale olive (10Y 6/2) grading to medium bluish gray $(5 B 5 / 1)$ at $28 \mathrm{ft}$; very shelly including Mulinia congesta; subrounded quartz granules abundant in basal $2 \mathrm{ft}$

\section{Tar Heel Formation}

Sand; very fine to fine grading down to very fine to medium; subangular to angular; poorly sorted; silty; very micaceous; dense; light gray $(N 7)$ grading down to greenish gray $(5 G Y$ 6/1) at about $36 \mathrm{ft}$......

Silt, very clayey, sandy (very fine), dense, stiff, carbonaceous; medium greenish gray (5GY 6/1) grading down to dark brownish gray (5YR $3 / 1$ ); contains 0.5 -cm-diameter waxy clayballs

Base of Varina Grove unit:

Base of Duplin Formation:

$+116 \mathrm{ft}$ above sea level

$+104 \mathrm{ft}$ above sea level

\section{Bottomed in Tar Heel Formation}


NL-4-06: $3.45 \mathrm{mi}$ west of eastern quadrangle border, $7.20 \mathrm{mi}$ north of southern quadrangle border, on eastern side of abandoned house $0.05 \mathrm{mi}$ south-southwest of junction of North Carolina State Roads 1932 and 1977, in north-central 1/9th of map area (latitude $34.7296^{\circ} \mathrm{N}$., longitude $78.9352^{\circ} \mathrm{W}$.). Surface elevation $145 \mathrm{ft}$.

\section{LITHOLOGY}

DEPTH, IN FEET

\section{Varina Grove unit}

Sand, fine to coarse, subangular to subrounded, silty,

clayey; dusky yellow (5Y 6/4) grading down to

dark yellowish orange (10YR 6/6).

Sand, fine to medium, subangular to subrounded, silty,

clayey, stiff; dark yellowish orange (10YR 6/6)

grading down to light gray $(N 7)$ with light-

yellowish-brown (10YR 6/4) mottles

Sand, fine to coarse, subangular to subrounded, silty,

clayey, stiff, dense; brownish gray (5YR 4/1)

grading down to grayish brown (5YR 4/2) ...

Sand; fine to medium grading down to medium to

coarse; subangular to subrounded; slightly silty;

grayish brown (5YR 4/2)

\section{UNCONFORMITY}

\section{Duplin Formation}

Sand, fine, well-sorted, silty, light-yellowishorange (10YR 7/8); lower contact gradational.

Sand, fine to coarse, poorly sorted, silty, brightyellowish-orange (10YR 6/8); scattered clayballs up to $0.5 \mathrm{~cm}$ in diameter

\section{UNCONFORMITY}

\section{Tar Heel Formation}

Sand, very fine, silty, clayey, micaceous, medium-gray $(N 5)$; lower contact gradational

Silt, very clayey, stiff, very dense, mediumgray ( $N 5)$

Silt, very clayey, stiff, very dense, carbonaceous; greasy luster; dark brownish gray (5YR 3/1); lower contact gradational 
Silt, very clayey, stiff, very dense, medium-

olive-gray (5Y 5/1)....

28-31

Base of Varina Grove unit:

$+128 \mathrm{ft}$ above sea level

Base of Duplin Formation:

$+124 \mathrm{ft}$ above sea level

Bottomed in Tar Heel Formation 


\section{Roseboro Quadrangle}

RB-1-05: $1.21 \mathrm{mi}$ west of eastern quadrangle border, $2.26 \mathrm{mi}$ north of southern quadrangle border, on eastern side of North Carolina Highway 242, 1.4 mi south-southeast of Mill Creek Church, in southeast 1/9th of map area (latitude $34.9077^{\circ} \mathrm{N}$., longitude $78.5212^{\circ} \mathrm{W}$.). Surface elevation $135 \mathrm{ft}$.

LITHOLOGY

DEPTH, IN FEET

\section{Dune sand}

Sand, fine to medium, clean; dusky yellowish brown

(10YR 2/2) grading rapidly to light yellowish brown

(10YR 6/4)

Sand, fine to medium, silty; light yellowish brown

(10YR 6/4) grading down through dark yellowish orange

$(10 Y R$ 6/6) (2-5 ft) and pale grayish orange (10YR 8/4)

$(5-17 \mathrm{ft})$ to orange $(10 Y R$ 7/8)

\section{Waccamaw Formation, Bahramsville unit}

Silt, clayey, sandy (very fine); pale yellowish brown

$(10 Y R 6 / 2)$ grading down through pale yellowish gray

$(5 Y 8 / 2)(18.5-26 \mathrm{ft})$ to yellowish orange (10YR 7/6)

Sand; very fine to fine grading down to medium to

coarse; pale grayish orange (10YR $8 / 4)$ grading in

basal foot to dark yellowish orange (10YR 6/6)

\section{UNCONFORMITY}

\section{Tar Heel Formation}

Sand, very fine, clayey, silty, micaceous, lignitic, stiff, dense; interbedded with clayey, very

fine, sandy silt; dark greenish gray $(5 G Y 3 / 1)$.

Base of dune sand:

Base of Waccamaw Formation, Bahramsville unit:

\section{Bottomed in Tar Heel Formation}

$+117 \mathrm{ft}$ above sea level

+101 ft above sea level 
RB-2-05: $1.09 \mathrm{mi}$ west of eastern quadrangle border, $7.15 \mathrm{mi}$ north of southern quadrangle border, on southeastern side of North Carolina State Road 1401, 0.15 mi west-southwest of intersection of North Carolina State Road 1401 and 1002 , in northeastern $1 / 9$ th of map area (latitude $34.9789^{\circ} \mathrm{N}$., longitude $78.5187^{\circ} \mathrm{W}$.). Surface elevation $132 \mathrm{ft}$.

\section{LITHOLOGY}

DEPTH, IN FEET

\section{Waccamaw Formation, Bahramsville unit}

Sand, very fine to fine, silty, light-yellowish-brown

$(10 Y R$ 6/4)

Sand; very fine to fine grading down to fine to medium;

clayey; silty; stiff; dense; light brown (5YR 6/6)......

Sand, medium to very coarse, poorly sorted, granular,

light-brown (5YR 56/6) .

Silt, sandy (very fine), clayey, stiff; yellowish gray (5Y 8/1) grading down to dark

yellowish orange (10YR 6/6) at $11 \mathrm{ft}$.

Sand; very fine to fine grading down to fine to medium;

yellowish orange (10YR 7/6); lower contact

somewhat gradational

Sand, coarse to very coarse, pebbly; pale grayish

orange (10YR 8/4) grading down to dark yellowish

orange (10YR 6/6) .....

\section{UNCONFORMITY}

\section{Tar Heel Formation}

Silt, sandy (very fine); interbedded with very fine, silty sand; micaceous; lignitic; stiff; dark greenish gray $(5 G Y 3 / 1)$

Base of Waccamaw Formation, Bahramsville unit:

$+108 \mathrm{ft}$ above sea level

\section{Bottomed in Tar Heel Formation}


RB-3-05: $3.54 \mathrm{mi}$ west of eastern quadrangle border, $4.30 \mathrm{mi}$ north of southern quadrangle border, on northeastern side of North Carolina State Road 1255 on western side of cemetery, $1.1 \mathrm{mi}$ northwest of intersection of North Carolina State Road 1255 and 1246, in central 1/9th of map area (latitude $34.9375^{\circ} \mathrm{N}$., longitude $78.5617^{\circ} \mathrm{W}$.). Surface elevation $128 \mathrm{ft}$.

\section{LITHOLOGY}

DEPTH, IN FEET

\section{Dune sand}

Sand, fine to medium, slightly silty; dark yellowish brown (10YR 3/2) grading rapidly

to light yellowish brown (10YR 6/4)

Sand, fine to medium, silty; pale yellowish gray (5Y 8/2)

grading down to dark yellowish orange $10 Y R$ 6/6).....

\section{UNCONFORMITY}

\section{Waccamaw Formation, Bahramsville unit}

Silt, clayey, very fine to fine sandy, stiff, yellowishgray $(5 Y 7 / 2)$

Silt, clayey, sandy (very fine), stiff, dense; yellowish gray

(5Y 8/1) with sparse reddish-brown (10R 5/6) mottles....

Sand; fine to medium grading rapidly down to medium to coarse; pale yellowish gray ( $5 Y$ 8/2) grading down through orange (10YR 7/8) (16-20 ft) and through light yellowish gray (5Y 8/1) (20-26 ft), returning to orange $(10 Y R$ 7/8)

\section{UNCONFORMITY}

\section{Tar Heel Formation}

Silt, very clayey, micaceous; upper 6 in. weathered to dark yellowish brown (10YR 4/2);

dark greenish gray $(5 G Y 3 / 1)$ below

Base of dune sand:

Base of Waccamaw Formation, Bahramsville unit:

\section{Bottomed in Tar Heel Formation}

$+123 \mathrm{ft}$ above sea level

$+100 \mathrm{ft}$ above sea level 
RB-4-05: $5.84 \mathrm{mi}$ west of eastern quadrangle border, $1.42 \mathrm{mi}$ north of southern quadrangle border, on northeastern side of North Carolina State Road 2040 on western side of cemetery, $1.25 \mathrm{mi}$ west of Beaver Dam School, in southwest 1/9th of map area (latitude $34.8956^{\circ} \mathrm{N}$., longitude $78.6023^{\circ} \mathrm{W}$.). Surface elevation $117 \mathrm{ft}$.

\section{LITHOLOGY}

DEPTH, IN FEET

\section{Dune sand}

Sand, fine to medium, soft, humic, dusky-yellowishbrown $(10 Y R 2 / 2)$

Sand; fine to medium grading down to medium; soft;

pale orange (10YR 7/2) grading down to light

grayish brown (5YR 4/2).

\section{Waccamaw Formation, Bahramsville unit}

Sand, fine, silty, clayey, very pale brown (5YR 6/2).....

Silt, clayey, stiff and dense; dark grayish orange (10YR 5/6) grading down to dark grayish orange (10YR 5/6) with pale-yellowish-gray (5Y 8/2) mottles

Sand; very fine grading down through fine to medium and medium to coarse to medium to very coarse; subangular to subrounded; silty; clayey; micaceous; yellowish orange (10YR 7/6) grading rapidly down through pale grayish orange (10YR 8/4) (23-24 ft) to orange (10YR 7/8); locally abundant quartz granules and small pebbles

\section{Tar Heel Formation}

Silt, clayey, micaceous, very lignitic, darkgreenish-gray (5GY 3/1); thin lenses of micaceous, fine sand below $29 \mathrm{ft}$

Base of dune sand:

Base of Waccamaw Formation, Bahramsville unit:

\section{Bottomed in Tar Heel Formation}


RB-5-05: $6.22 \mathrm{mi}$ west of eastern quadrangle border, $7.48 \mathrm{mi}$ north of southern quadrangle border, on southern side of power line south of (and parallel to) North Carolina Highway 24, 0.9 mi east of western quadrangle boundary, in northwest $1 / 9$ th of map area (latitude $34.9837^{\circ} \mathrm{N}$., longitude $78.6089^{\circ} \mathrm{W}$.). Surface elevation $145 \mathrm{ft}$.

\section{LITHOLOGY}

DEPTH, IN FEET

\section{Dune sand}

Sand; fine to medium grading down to medium to coarse;

light yellowish brown (10YR 6/4) grading down through pale

orange (10YR 7/2) to yellowish orange (10YR 7/6).

Sand, fine to medium; pale orange (10YR $7 / 2)$ grading down

through yellowish orange (10YR 7/6) (8-10 ft),

back to pale orange (10YR 7/2) (10-11 ft), and

then to light yellowish brown (10YR 6/4)

\section{UNCONFORMITY}

\section{Waccamaw Formation, Bahramsville unit}

Silt, clayey, sandy (very fine), yellowish-gray (5Y 8/1).

Sand; very fine to fine grading down to medium to coarse;

subangular; yellowish orange (10YR 7/6); lower contact

somewhat gradational

Sand, medium to very coarse, subangular, poorly sorted,

silty, yellowish-gray (5Y 8/1).

Sand, medium to very coarse, subangular, poorly sorted, silty; yellowish gray ( $5 Y$ 8/1) grading down to grayish yellow (5Y 7/4); abundant rounded quartz granules and small pebbles...

\section{UNCONFORMITY}

\section{Tar Heel Formation}

Silt, very clayey, micaceous, sparsely lignitic, dense, sticky, dark-greenish-gray (5GY 3/1)

Base of dune sand:

Base of Waccamaw Formation, Bahramsville unit:
$+132 \mathrm{ft}$ above sea level

$+109 \mathrm{ft}$ above sea level

\section{Bottomed in Tar Heel Formation}


RB-6-08: $1.21 \mathrm{mi}$ west of eastern quadrangle border, $2.26 \mathrm{mi}$ north of southern quadrangle border, on southeastern side of dirt road, $0.05 \mathrm{mi}$ northeast of North Carolina Highway 210 and $0.14 \mathrm{mi}$ north of Evergreen Church, westcentral 1/9th of map area (latitude $34.9492^{\circ} \mathrm{N}$., longitude $78.6205^{\circ} \mathrm{W}$.). Surface elevation $117 \mathrm{ft}$.

\section{LITHOLOGY}

DEPTH, IN FEET

\section{Dune sand}

Sand, fine to medium, slightly silty, soft; light

yellowish brown (10YR 6/4) grading down through dark

yellowish orange (10YR 6/6) to dark yellowish

orange (10YR 5/6); one large, subrounded, elongate

quartz granule at base

\section{UNCONFORMITY}

\section{Waccamaw Formation, Bahramsville unit}

Sand, fine to medium, silty, slightly clayey, dense, yellowish-orange (10YR 7/6); lower contact somewhat gradational

Sand, very fine to fine, very clayey, silty, stiff; very light gray ( $N$ 8) with light-brown (5YR 5/6) mottles; lower contact somewhat gradational

Sand, very fine to fine, very silty, slightly clayey; very light gray $(N 8)$ grading down to pale yellowish gray (5Y 8/2) with dark-orange (10YR 6/8) mottles; lower contact somewhat gradational

Sand, fine to very coarse, subangular to angular, very poorly sorted, silty, soft; yellowish orange (10YR 7/6) with pale-grayish-orange (10YR 7/4) mottles.

Sand, fine to coarse, subangular to angular, poorly sorted, silty, soft; yellowish orange (10YR 7/6) grading down to medium orange $(10 Y R$ 7/8) at $13 \mathrm{ft}$; lower contact somewhat gradational

Sand, medium to very coarse, subangular to angular, poorly sorted, medium-orange (10YR 7/8); contains rounded to subrounded quartz pebbles up to $1 \mathrm{~cm}$ in diameter

Sand, fine, well-sorted; 2-5 percent very fine, dark, heavy mineral grains; pale yellowish gray (5Y 8/2) with pale-olive $(10 Y 6 / 2)$ streaks.

Sand, medium to very coarse, subangular to angular, poorly sorted; medium orange (10YR 7/4) grading down through very pale orange (10YR $8 / 2$ ) to bright orange (10YR 6/8); contains rounded to subrounded quartz pebbles up to $3 \mathrm{~cm}$ in diameter .... 


\section{Tar Heel Formation}

Clay, silty, very micaceous; weathered dark yellowish

orange (10YR 6/6) at top, dark brownish gray (5YR 3/1)

beneath; laminae of clean, very fine sand ....

Base of dune sand:

Base of Waccamaw Formation, Bahramsville unit:
$+112 \mathrm{ft}$ above sea level $+91.5 \mathrm{ft}$ above sea level

\section{Bottomed in Tar Heel Formation}


RB-7-08: $2.38 \mathrm{mi}$ west of eastern quadrangle border, $3.05 \mathrm{mi}$ north of southern quadrangle border, at crest of small hill on southern side of unnumbered dirt road, $0.6 \mathrm{mi}$ southeast of junction of unnumbered dirt road with North Carolina State Road 1246, on boundary between central and east-central 1/9th of map area (latitude $34.9192^{\circ} \mathrm{N}$., longitude $78.5414^{\circ} \mathrm{W}$.). Surface elevation $125 \mathrm{ft}$.

\section{LITHOLOGY}

DEPTH, IN FEET

\section{Dune sand}

Sand, fine to medium, slightly silty, soft, dark-yellowishorange (10YR 6/6); lower contact gradational.

Sand; fine grading down to fine to medium,

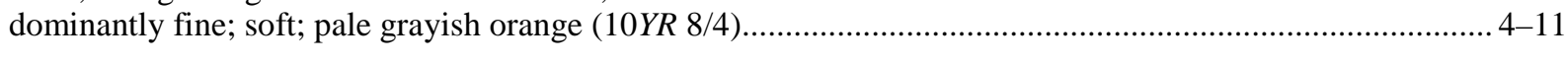

Sand, fine to medium, soft, yellowish-orange (10YR 7/6) …....................................................................... 11-12

\section{UNCONFORMITY}

\section{Waccamaw Formation, Bahramsville unit}

Sand, fine to medium, silty, clayey, stiff, yellowishorange (10YR 7/6); lower contact gradational.

Sand, fine to coarse, poorly sorted, clayey, silty, stiff, pale-grayish-orange pink (5YR 8/2); clay and silt content decreases downward.

Sand, medium to very coarse, poorly sorted, clayey, silty, dark-yellowish-orange (10YR 6/6); contains subangular to subrounded granules.

\section{Tar Heel Formation}

Clay, dense, sticky, silty; weathered yellowish brown $(10 Y R 5 / 2)$ at top but grades rapidly down to dark olive gray $(5 Y 3 / 1)$ at $22.5 \mathrm{ft}$; sparse fine mica and very fine quartz-sand laminae.

Sand; fine to medium grading down to fine; silty; clayey; locally woody; abundant coarse mica; yellowish brown (10YR 5/2) grading down through yellowish brown $(10 Y R 5 / 2)$ with streaks of medium orange (10YR 7/8) and bright orange (10YR 6/8) to all medium orange (10YR 7/8)

Base of dune sand:

Base of Waccamaw Formation, Bahramsville unit:
$+113 \mathrm{ft}$ above sea level

$+103 \mathrm{ft}$ above sea level

\section{Bottomed in Tar Heel Formation}




\section{Rose Hill Quadrangle}

RH-1-04: 1.55 mi west of eastern quadrangle border, $3.41 \mathrm{mi}$ north of southern quadrangle border, on western side of road leading to old quarry, 0.3 mi south of North Carolina State Road 1148, 1.55 mi west of eastern quadrangle boundary, in east-central 1/9th of map area (latitude $34.7997^{\circ} \mathrm{N}$., longitude $78.0273^{\circ} \mathrm{W}$.). Surface elevation $70 \mathrm{ft}$.

\section{LITHOLOGY}

DEPTH, IN FEET

\section{Charles City Formation}

Sand, very fine to fine, silty, dark-yellowish-

brown $(10 Y R 3 / 2)$

Sand, very fine, silty, clayey, dark-yellowishorange $(10 Y R$ 6/6)

Silt, clayey, sandy (very fine), yellowish-gray

$(5 Y 8 / 1)$

Sand, fine to medium, yellowish-gray (5Y 8/1);

lower contact somewhat gradational

Sand, medium to coarse, slightly silty, medium-

olive-gray (5Y 5/1)

\section{Castle Hayne Limestone}

Sand, fine to medium, silty, thixotropic, lightolive-brown (5Y 5/4); abundant shell fragments

Calcarenite, medium to coarse, weathered, soft, crumbly, light-yellowish-brown (10YR 6/4)

Calcarenite, medium to coarse, quartzose, soft, crumbly, light-greenish-gray (5GY 7/1); abundant shell fragments and echinoid spines; phosphate pebble $1 \mathrm{~cm}$ in diameter at base*

Calcarenite, fine, silty, medium-greenish-gray (5GY 5/1); medium to coarse quartz -sand grains in basal 6 in.

\section{UNCONFORMITY}

\section{Donoho Creek Formation}

Sand, fine, silty, micaceous, dark-greenishgray $(5 G Y 3 / 1)$ 
Sand, fine, silty, clayey, micaceous, sparsely

shelly, dark-greenish-gray (5GY 3/1)

$41-46$

Base of Charles City Formation:

+54 ft above sea level

Base of Castle Hayne Limestone:

$+42 \mathrm{ft}$ above sea level

\section{Bottomed in Donoho Creek Formation}

*Eocene calcareous nannofossil assemblage recovered at $23 \mathrm{ft}$ (Jean M. Self-Trail, USGS, oral commun., 2004). 
RH-2-04: $2.63 \mathrm{mi}$ west of eastern quadrangle border, $7.44 \mathrm{mi}$ north of southern quadrangle border, on eastern side of dirt road leading south from North Carolina State Road 1177, $0.3 \mathrm{mi}$ south of southern end of Johnsons Lake dam, in north-central 1/9th of map area (latitude $34.8579^{\circ} \mathrm{N}$., longitude $78.0459^{\circ} \mathrm{W}$.). Surface elevation $100 \mathrm{ft}$.

\section{LITHOLOGY}

DEPTH, IN FEET

\section{Windsor Formation, barrier sand facies}

Sand, medium, clean, medium-grayish-orange-

pink $(5 Y R$ 8/2)

Sand, fine to medium; yellowish brown (10YR 5/2)

grading down through dusky brown (5YR 2/1) (2-5 ft)

to dark yellowish brown (10YR 3/2)

Windsor Formation, back-barrier facies

Sand, fine, silty, clayey, pale-olive-gray (5Y 7/1)

Sand, fine to medium, silty, clayey, medium-light-

gray $(N 6)$

\section{Bladen Formation}

Sand, very fine, clayey, silty, light-olive-gray (5Y 6/1).

Sand, fine to medium, silty, clayey, massive, olive-

gray ( $5 Y 5 / 1)$; phosphate pebbles up to $2 \mathrm{~cm}$ in

diameter at basal contact.....

$15.5-39$

\section{UNCONFORMITY}

\section{Tar Heel Formation}

Clay, dense, massive, light-olive-gray ( $5 Y$ 5/2);

contains sparse nodules

Base of Windsor Formation, barrier sand facies:

Base of Windsor Formation, back-barrier facies:

Base of Bladen Formation:

$+94 \mathrm{ft}$ above sea level

$+85 \mathrm{ft}$ above sea level

$+61 \mathrm{ft}$ above sea level

\section{Bottomed in Tar Heel Formation}


RH-3-04: $6.89 \mathrm{mi}$ west of eastern quadrangle border, $3.84 \mathrm{mi}$ north of southern quadrangle border, at abandoned home site on southeastern side of North Carolina State Road 1102, 0.05 mi south of intersection of North Carolina State Road 1102 and 1126 , in west-central 1/9th of map area (latitude $34.8058^{\circ} \mathrm{N}$., longitude $78.12005^{\circ} \mathrm{W}$.). Surface elevation $90 \mathrm{ft}$.

\section{LITHOLOGY}

DEPTH, IN FEET

Artificial fill $0-1$

\section{UNCONFORMITY}

\section{Windsor Formation}

Sand; very fine to fine with minor medium to coarse grains;

silty; clayey; stiff; dense; light brown ( $5 Y R$ 5/6) grading down

through yellowish orange (10YR 5/6) (3-6 ft) to light brown

(5YR 5/6); thin layers of very clayey silt at $9 \mathrm{ft}$ and $14 \mathrm{ft}$

Sand, fine to medium, silty, soft, yellowish-orange

(10YR 7/6); contains a light-olive-gray ( $5 Y 5 / 2)$, very

clayey silt lens at $18 \mathrm{ft}$.

\section{UNCONFORMITY}

\section{Bladen Formation}

Sand, very fine to fine, silty, clayey, dense, dark-greenish-

gray $(5 G Y 4 / 1)$...

Sand; varies from fine to medium to medium to coarse;

silty; clayey; dark greenish gray (5GY 4/1).

Sand, medium, silty, shelly, light-olive-gray (5Y 5/2);

quartz granules and sparse phosphate sand*....

\section{Base of Windsor Formation:}

\section{Bottomed in Bladen Formation}

*Recovered Upper Cretaceous (Campanian) calcareous nannofossil

Zone CC 21 assemblage at $50 \mathrm{ft}$ (Jean M. Self-Trail, USGS, oral commun., 2004). 
RH-4-04: 3.90 mi west of eastern quadrangle border, $1.43 \mathrm{mi}$ north of southern quadrangle border, on southern side of North Carolina State Road 1135, 0.35 mi west-southwest of Providence Church, in south-central 1/9th of map area (latitude $34.7710^{\circ} \mathrm{N}$., longitude $78.0681^{\circ} \mathrm{W}$.). Surface elevation $75 \mathrm{ft}$.

\section{LITHOLOGY}

DEPTH, IN FEET

\section{Charles City Formation}

Sand, very fine, silty, clayey; yellowish brown (10YR 5/6)

grading down through light yellowish brown (10YR 6/4) (1-5 ft)

to dark yellowish gray $(5 Y 7 / 1)$ $0-6$

\section{UNCONFORMITY}

\section{Bladen Formation}

Sand; fine to medium grading down to fine; slightly silty and clayey; grayish yellow ( $5 Y$ 7/4) grading rapidly down to dark grayish olive green (5GY 2/2) at $7 \mathrm{ft}$.

Sand, fine, silty, clayey, micaceous, dark-grayish-olivegreen (5GY 2/2); sparsely shelly below $30 \mathrm{ft}$; pyrite nodules at $33 \mathrm{ft} *$.

\section{Base of Charles City Formation:}

\section{Bottomed in Bladen Formation}

*Recovered Upper Cretaceous (Campanian) calcareous nannofossil

Zone CC 21 assemblage at $33 \mathrm{ft}$ (Jean M. Self-Trail, USGS, oral commun., 2004). 
RH-5-04: $1.48 \mathrm{mi}$ west of eastern quadrangle border, $8.07 \mathrm{mi}$ north of southern quadrangle border, in field on western side of North Carolina State Road 1915, 0.25 mi northwest of bridge over Beaverdam Creek, in northeastern 1/9th of map area (latitude $34.8670^{\circ} \mathrm{N}$., longitude $78.0255^{\circ} \mathrm{W}$.). Surface elevation $80 \mathrm{ft}$.

\section{LITHOLOGY}

DEPTH, IN FEET

\section{Charles City Formation}

Sand; fine with scattered rounded, medium to coarse grains; slightly silty; yellowish orange (10YR 7/6)

Sand, fine; yellowish orange (10YR 7/6) grading down through dusky yellowish brown (10YR 2/2) (4-5 ft)

to medium yellowish brown (10YR 5/4) ....

\section{Windsor Formation}

Sand, very fine to fine, very clayey and silty, sticky, soft, light-olive-gray (5Y 5/2)...

Sand, fine, slightly silty and clayey, light-olivegray $(5 Y 5 / 2)$

Sand, very fine to fine, very silty and clayey, olivegray $(5 Y 3 / 2)$

Sand, fine, slightly silty and clayey, dark-greenishgray (5GY 4/1); sparse wood chips

Sand, fine to medium, clayey, silty, dark-greenishgray (5GY 4/1); sparse wood chips

Sand, fine to medium, dark-greenish-gray (5GY 4/1); interbedded with very clayey and silty, very fine sand; micaceous

\section{UNCONFORMITY}

\section{Castle Hayne Limestone}

Calcarenite, very fine, very clayey, dense, stiff, dark-greenish-gray (5GY 4/1); interbedded with scattered lenses of fine sand.

Calcarenite, fine to medium, locally very clayey; chalky shells; dark greenish gray (5GY 4/1)..... 
Calcarenite, very fine, dense, very clayey and silty, dark-greenish-gray (5GY 4/1); sparse rotten shells

scattered throughout; sparse wood chips...

43-51

Base of Charles City Formation:

Base of Windsor Formation:

$+50 \mathrm{ft}$ above sea level

Bottomed in Castle Hayne Limestone 
RH-6-04: $1.12 \mathrm{mi}$ west of eastern quadrangle border, $3.14 \mathrm{mi}$ north of southern quadrangle border, on northern side of far northeastern end of dirt road, $0.05 \mathrm{mi}$ west of Seaboard Railroad Line, $0.35 \mathrm{mi}$ southeast of abandoned quarry, in east-central 1/9th of map area (latitude $34.7956^{\circ} \mathrm{N}$., longitude $78.0190^{\circ} \mathrm{W}$.). Surface elevation $74 \mathrm{ft}$.

\section{LITHOLOGY}

DEPTH, IN FEET

\section{Charles City and Windsor Formations (undivided)}

Sand, silty, dark-greenish-gray (5G 4/1); not logged

in detail; sparsely shelly below $49 \mathrm{ft}$; abrupt basal

contact.

\section{UNCONFORMITY}

\section{Donoho Creek Formation}

Sand, very fine, silty, clayey, shelly, olive-gray

(5Y 4/2); contains lumps of limestone up to $5 \mathrm{~cm}$

in diameter; basal lag bed present

\section{Bladen Formation}

Calcarenite, fine, well-sorted, quartzose, sparsely shelly,

dark-greenish-gray (5GY 4/1) to dark-grayish-green (5GY 4/2)

Base of Charles City Formation:

Base of Windsor Formation:

Base of Donoho Creek Formation:

Bottomed in Bladen Formation (not determined)

$+15 \mathrm{ft}$ above sea level

$+\mathbf{1 1} \mathbf{f t}$ above sea level 
RH-7-04: $2.63 \mathrm{mi}$ west of eastern quadrangle border, $7.44 \mathrm{mi}$ north of southern quadrangle border, $0.5 \mathrm{mi}$ westsouthwest of RH-6-04 on southeastern side of road, in east-central 1/9th of map area (latitude $34.7923^{\circ} \mathrm{N}$., longitude $78.0262^{\circ} \mathrm{W}$.). Surface elevation $74 \mathrm{ft}$.

\section{LITHOLOGY}

DEPTH, IN FEET

\section{Charles City Formation}

Sand, silty; not logged in detail.

\section{UNCONFORMITY}

\section{Donoho Creek Formation}

Sand; fine to medium, dominantly fine; grading down to medium to coarse at base; very calcareous; silty; clayey; very dense; dark olive gray (5Y 3/1)

Base of Charles City Formation:

$+51 \mathrm{ft}$ above sea level

\section{Bottomed in Donoho Creek Formation}


RH-8-04: $1.31 \mathrm{mi}$ west of eastern quadrangle border, $3.03 \mathrm{mi}$ north of southern quadrangle border, $0.25 \mathrm{mi}$ westsouthwest of RH-6-04 on northwestern side of road, in east-central $1 / 9$ th of map area (latitude $34.7942^{\circ} \mathrm{N}$., longitude $78.0227^{\circ} \mathrm{W}$.). Surface elevation $74 \mathrm{ft}$.

\section{LITHOLOGY}

DEPTH, IN FEET

\section{Charles City Formation}

Sand, silty and clayey; not logged in detail.

\section{UNCONFORMITY}

\section{Windsor Formation}

Silt, clayey, dark-greenish-gray (5G 4/1)

\section{Donoho Creek Formation}

Sand, fine to medium, silty, clayey, dense, dark-olive-gray

$(5 Y 3 / 1)$

$17-26$

Base of Charles City Formation:

$+61 \mathrm{ft}$ above sea level

Base of Windsor Formation:

$+57 \mathrm{ft}$ above sea level

Bottomed in Donoho Creek Formation 
RH-9-04: $0.04 \mathrm{mi}$ west of eastern quadrangle border, $3.23 \mathrm{mi}$ north of southern quadrangle border, at northwestern corner of field, $1.05 \mathrm{mi}$ east-northeast of RH-6-04, in east-central 1/9th of map area (latitude $34.7972^{\circ} \mathrm{N}$., longitude $78.0006^{\circ} \mathrm{W}$.). Surface elevation $76 \mathrm{ft}$.

\section{LITHOLOGY}

DEPTH, IN FEET

\section{Charles City Formation}

Sand, silty and clayey; not logged in detail.

\section{UNCONFORMITY}

\section{Windsor Formation}

Silt, clayey, sparsely shelly, dark-greenishgray $(5 G 4 / 1)^{*}$

\section{Donoho Creek Formation}

Sand, fine to coarse, poorly sorted, clayey, silty, dense, olive-gray ( $5 Y 3 / 1.5)$; local pyrite nodules*

Sand, fine to coarse, poorly sorted, clayey, silty, dense, olive-gray ( $5 Y 3 / 2)$; sparse shells and abundant limestone nodules reworked from unit below.

\section{Bladen Formation}

Calcarenite, very fine; more clayey than unit above; dense; very fine mica and small pyrite nodules;

\section{Base of Charles City Formation:}

Base of Windsor Formation:

Base of Donoho Creek Formation:

\section{Bottomed in Bladen Formation}

*Recovered calcareous nannofossils, including Pliocene to Pleistocene Gephyrocapsa at $19 \mathrm{ft}$, an Upper Cretaceous (Campanian) Zone CC 22a/b assemblage at $29 \mathrm{ft}$, and an Upper Cretaceous (Campanian) Zone CC 21 assemblage at $50 \mathrm{ft}$ (Jean M. Self-Trail, USGS, oral commun., 2004).
$+66 \mathrm{ft}$ above sea level

$+55 \mathrm{ft}$ above sea level

$+28 \mathrm{ft}$ above sea level 
RH-10-04: $0.69 \mathrm{mi}$ west of eastern quadrangle border, $3.59 \mathrm{mi}$ north of southern quadrangle border, at end of farm road shown on map on eastern side of U.S. Highway 117, 0.6 mi northeast of RH-6-04 and just south of closed 80-ft contour around small hill, in east-central $1 / 9$ th of map area (latitude $34.8023^{\circ} \mathrm{N}$., longitude $78.0118^{\circ} \mathrm{W}$.). Surface elevation $79 \mathrm{ft}$.

LITHOLOGY

DEPTH, IN FEET

\section{Charles City Formation}

Sand, silty and clayey; not logged in detail.

$0-13$

\section{UNCONFORMITY}

\section{Donoho Creek Formation}

Sand, fine to coarse, poorly sorted, clayey, silty, dense, olive-gray (5Y 3/1.5); local pyrite nodules

\section{Base of Charles City Formation:}

\section{Bottomed in Donoho Creek Formation}


RH-11-04: $0.32 \mathrm{mi}$ west of eastern quadrangle border, $5.64 \mathrm{mi}$ north of southern quadrangle border, at site of old chicken coops on southern side of Island Creek, $0.7 \mathrm{mi}$ east-northeast of lookout tower on northeastern side of Rose Hill, in east-central 1/9th of map area (latitude $34.8322^{\circ} \mathrm{N}$., longitude $78.0056^{\circ} \mathrm{W}$.). Surface elevation $86 \mathrm{ft}$.

\section{LITHOLOGY}

DEPTH, IN FEET

\section{Windsor Formation}

Sand, silty and clayey; not logged in detail

Silt, clayey, dark-greenish-gray (5G 4/1)

\section{Donoho Creek Formation}

Sand, fine to medium, clayey, silty, stiff, dark-

olive-gray (5Y 3/1).

$17-26$

Base of Windsor Formation:

$+69 \mathrm{ft}$ above sea level

\section{Bottomed in Donoho Creek Formation}


RH-12-04: $0.41 \mathrm{mi}$ west of eastern quadrangle border, $6.03 \mathrm{mi}$ north of southern quadrangle border, on northern side of abandoned house on northern side of Island Creek, $0.8 \mathrm{mi}$ northeast of lookout tower on northeastern side of Rose Hill, in northeastern $1 / 9$ th of map area (latitude $34.8378^{\circ} \mathrm{N}$., longitude $78.0069^{\circ} \mathrm{W}$.). Surface elevation $87 \mathrm{ft}$.

\section{LITHOLOGY}

DEPTH, IN FEET

Windsor Formation

Sand, silty and clayey; not logged in detail.

\section{UNCONFORMITY}

\section{Donoho Creek Formation}

Sand; fine to medium grading down to medium to coarse; dark olive gray ( $5 Y 3 / 1)$; shelly

in basal foot, including thick oyster-shell fragment

\section{Bladen Formation}

Calcarenite, fine, clayey, dense, sparsely shelly, olive-gray (5Y 3/2)

Base of Windsor Formation:

Base of Donoho Creek Formation:
$+74 \mathrm{ft}$ above sea level

+68 ft above sea level

\section{Bottomed in Bladen Formation}


RH-13-04: $0.47 \mathrm{mi}$ west of eastern quadrangle border, $5.91 \mathrm{mi}$ north of southern quadrangle border, $0.15 \mathrm{mi}$ southsouthwest of RH-12-04, $300 \mathrm{ft}$ west of upstream end of a small ponded segment of Island Creek, in northeastern 1/9th of map area (latitude $34.8359^{\circ} \mathrm{N}$., longitude $78.0079^{\circ} \mathrm{W}$.). Surface elevation $67 \mathrm{ft}$.

\section{LITHOLOGY}

DEPTH, IN FEET

\section{Alluvium}

Sand, dark-olive-gray (5Y 3/1); not logged in detail. $0-10$

\section{UNCONFORMITY}

\section{Bladen Formation}

Calcarenite, fine, shelly, olive-gray (5Y 3/2) $10-31$

Calcarenite, fine to medium, shelly, dark-green

(5G 4/2); abundant quartz, glauconite, and phosphate sand $31-36$

Calcarenite, fine, olive-gray (5Y 3/2)* $36-49$

Calcarenite, fine, very shelly, olive-gray ( $5 Y 3 / 2)$ $49-51$

\section{Base of alluvium:}

$+57 \mathrm{ft}$ above sea level

\section{Bottomed in Bladen Formation}

*Recovered an Upper Cretaceous (Campanian) calcareous nannofossil Zone CC 21 assemblage at $40 \mathrm{ft}$ (Jean M. Self-Trail, USGS, oral commun., 2004). 
RH-14-04: $6.07 \mathrm{mi}$ west of eastern quadrangle border, $3.07 \mathrm{mi}$ north of southern quadrangle border, $0.05 \mathrm{mi}$ east of junction of dirt road (at 81-ft spot elevation) with North Carolina State Road 1133, 1.35 mi northwest of Friendship Church, in west-central 1/9th of map area (latitude $34.7945^{\circ} \mathrm{N}$., longitude $78.1062^{\circ} \mathrm{W}$.). Surface elevation $80 \mathrm{ft}$.

\section{LITHOLOGY}

DEPTH, IN FEET

\section{Charles City Formation}

Sand, very fine to fine, varicolored; not logged in detail

\section{UNCONFORMITY}

\section{Bladen Formation}

Sand; very fine to fine grading down to medium to coarse near base; finely micaceous; silty; clayey; dense; dark olive gray (5Y 3/1) $11-14$

\section{UNCONFORMITY}

\section{Tar Heel Formation}

Sand, very fine to fine, clayey, dense; glauconite sand abundant near top (probably in burrows from unit above); dark greenish gray (5GY 4/1) with dark-grayish-green (10GY 4/2), glauconite-rich areas

Sand, mostly fine; interbedded with very clayey silt; dense; tough; dark greenish gray (5GY 4/1); lignite in clayey silt in basal foot

Base of Charles City Formation:

Base of Bladen Formation:

\section{Bottomed in Tar Heel Formation}

$+69 \mathrm{ft}$ above sea level $+66 \mathrm{ft}$ above sea level 
RH-15-04: $6.00 \mathrm{mi}$ west of eastern quadrangle border, $4.78 \mathrm{mi}$ north of southern quadrangle border, $0.1 \mathrm{mi}$ west of bridge over Taylors Creek on northern side of North Carolina State Road 1102, $0.8 \mathrm{mi}$ east of Brices Crossroads, in west-central 1/9th of map area (latitude $34.8194^{\circ} \mathrm{N}$., longitude $78.0874^{\circ} \mathrm{W}$.). Surface elevation $72 \mathrm{ft}$.

\section{Tar Heel Formation}

Sand, fine, varicolored; no basal contact; probably

residuum; not logged in detail....

Sand, fine to medium, dark-grayish-green (10GY 4/2);

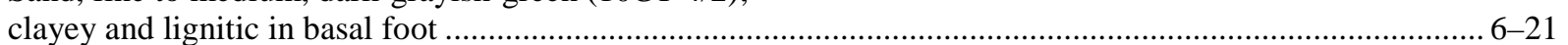

\section{Bottomed in Tar Heel Formation}


RH-16-04: $0.98 \mathrm{mi}$ west of eastern quadrangle border, $7.87 \mathrm{mi}$ north of southern quadrangle border, at northeastern end of limestone quarry too new to be shown on map, $0.15 \mathrm{mi}$ north-northeast of intersection of North Carolina State Road 1915 and 1911, in northeastern 1/9th of map area (latitude $34.8640^{\circ} \mathrm{N}$., longitude $78.0170^{\circ} \mathrm{W}$.). Surface elevation $80 \mathrm{ft}$.

\section{LITHOLOGY}

DEPTH, IN FEET

Disturbed earth. $0-4$

\section{UNCONFORMITY}

\section{Charles City Formation}

Sand, fine, dark-yellowish-brown (10YR 3/2);

contains abundant root fragments

Sand, fine, silty, slightly clayey; light grayish

olive (10Y 5/2) grading down through medium greenish

gray (5GY 5/1) to dark olive gray (5Y 2/2).

\section{UNCONFORMITY}

\section{Castle Hayne Limestone}

Calcarenite, fine to medium, medium-olive-gray

(5Y 5/1)

(Owner drilled site prior to opening pit and reports that

limestone extends down to depth of $90 \mathrm{ft}$ ).

\section{UNCONFORMITY}

\section{Tar Heel Formation}

(Owner reports that limestone is underlain by at least

Base of Charles City Formation:

Base of Castle Hayne Limestone:

$+69 \mathrm{ft}$ above sea level

$-10 \mathrm{ft}$ below sea level

\section{Bottomed in Tar Heel Formation}


RH-17-04: $3.23 \mathrm{mi}$ west of eastern quadrangle border, $4.53 \mathrm{mi}$ north of southern quadrangle border, $0.2 \mathrm{mi}$ beyond western-southwestern end of North Carolina State Road 1142, on northwestern side of road at western edge of field, 1.4 mi northwest of Lake Tut, in central 1/9th of map area (latitude $34.8158^{\circ} \mathrm{N}$., longitude $78.0563^{\circ} \mathrm{W}$.). Surface elevation $90 \mathrm{ft}$.

\section{LITHOLOGY}

DEPTH, IN FEET

\section{Windsor Formation}

Sand, fine, humic, silty; dusky yellowish brown

(10YR 3/2) grading down to dark yellowish brown

(10YR 4/4)

Sand, fine, humic, silty, medium-brownish-gray

(5YR 5/1); roots abundant in basal foot

Silt, sandy (very fine), clayey; grades down to

very fine, silty sand; yellowish gray (5Y 8/1).

Sand, very fine, silty; grades down to fine to medium at base; orange pink (10R 6/4) grading down rapidly

to yellowish orange (10YR 7/6) at $9 \mathrm{ft}$. $8-18$

Sand, fine, silty, shelly, pale-olive-gray (5Y 6/2) $18-20$

\section{UNCONFORMITY}

\section{Donoho Creek Formation}

Calcarenite, fine, sparsely shelly; dark olive gray (5Y 3/1)

grading down to dark greenish gray $(5 G Y 4 / 1)$ at $40 \mathrm{ft}^{*}$.

\section{Tar Heel Formation}

Silt, very clayey, dense, micaceous, lignitic; thin interbeds of fine sand; dark greenish gray (5GY 4/1) $51-55$

Sand, very fine, silty, micaceous, dark-greenish-gray (5GY 4/1)

\section{Base of Windsor Formation: Base of Donoho Creek Formation:}

\section{Bottomed in Tar Heel Formation}

*Recovered an Upper Cretaceous (Campanian) calcareous nannofossil Zone CC 22 assemblage at $24 \mathrm{ft}$ (Jean M. Self-Trail, USGS, oral commun., 2004). 
RH-18-04: 4.20 mi west of eastern quadrangle border, $6.95 \mathrm{mi}$ north of southern quadrangle border, on northern side of North Carolina State Road 1123, 0.25 mi west-northwest of intersection of North Carolina State Road 1123 and $1103,1.2 \mathrm{mi}$ southwest of Johnsons Lake, in north-central 1/9th of map area (latitude $34.8507^{\circ} \mathrm{N}$., longitude $78.0736^{\circ} \mathrm{W}$.). Surface elevation $125 \mathrm{ft}$.

\section{LITHOLOGY}

DEPTH, IN FEET

\section{Waccamaw Formation, Bahramsville unit}

Sand, fine, silty, grayish-yellow (5Y 8/4).

Sand, fine, silty; very fine, dark, heavy minerals

below 4-ft depth; dark yellowish brown

(10YR 4/2) grading down to pale grayish orange

(5YR 8/2)

Sand; very fine to fine with scattered medium grains;

thixotropic; pale yellowish brown (10YR 6/2);

lower contact gradational.

Silt, clayey, sandy (very fine), stiff, dense, very

light gray ( $N$ 8).....

Sand;fine grading down through fine to medium to medium to coarse; very light gray $(N 8)$

\section{Duplin Formation}

Sand, very fine, very silty; sparse shells in basal $4 \mathrm{ft}$; small quartz discoid $1 \mathrm{~cm}$ in maximum diameter on basal contact; pale brown (5YR 6/6) grading down through dark greenish gray (5G 3/1) (18-24 ft) to dark greenish gray $(5 G 4 / 1)$.....

\section{Bladen Formation}

Calcarenite, fine, quartzose, olive-gray ( $5 Y$ 4/1);

much denser than unit above.

Base of Waccamaw Formation, Bahramsville unit: Base of Duplin Formation:

\section{Bottomed in Bladen Formation}

$+108 \mathrm{ft}$ above sea level
$+97 \mathrm{ft}$ above sea level 
RH-19-08: $1.41 \mathrm{mi}$ west of eastern quadrangle border, $6.18 \mathrm{mi}$ north of southern quadrangle border, $100 \mathrm{ft}$ north of northern side of North Carolina State Road 1147, 0.16 mi east of intersection of North Carolina State Road 1147 with U.S. Highway 117 , in northeastern $1 / 9$ th of map area (latitude $34.8396^{\circ} \mathrm{N}$., longitude $78.0242^{\circ} \mathrm{W}$.). Surface elevation $100 \mathrm{ft}$.

\section{LITHOLOGY}

DEPTH, IN FEET

\section{Windsor Formation, barrier sand facies}

Sand, fine, silty, clayey; dark yellowish brown

(10YR 3/2) grading down to dark yellowish

orange (10YR 6/6) .

Sand, fine, silty, clayey, very dark yellowish

orange (10YR 5/6); plinthite nodules

at 5 -ft depth.

Sand, fine, slightly silty and clayey, thixotropic, grayish-orange (10YR 7/4)

\section{Windsor Formation, back-barrier facies}

Sand, very fine, silty, clayey, stiff, sticky;

yellowish gray ( $5 Y$ 8/1) with moderate-

reddish-brown (10R 4/6) streaks grading down

to dark yellowish orange (10YR 6/6).

Sand, fine to medium, slightly silty, yellowish-

orange (10YR 7/6) .....

Silt, very clayey, sandy (very fine); dark yellowish

orange (10YR 6/6) grading down to pale olive

brown $(10 Y 5 / 6)$

Sand, very fine, silty, slightly clayey, light-

yellowish-brown (10YR 6/4)

Sand, very fine, silty, slightly clayey, shelly, medium-greenish-gray $(5 G 5 / 1)^{*}$.....

\section{Bladen Formation}

Sand, fine, well-sorted, silty, clayey, micaceous, dark-olive-gray (5Y 3/1)...

Base of Windsor Formation, barrier sand facies:

Base of Windsor Formation, back barrier facies:

$+92.5 \mathrm{ft}$ above sea level $+76 \mathrm{ft}$ above sea level

\section{Bottomed in Bladen Formation}

*Mollusk taxa listed in appendix 3. 
RH-20-08: $0.62 \mathrm{mi}$ west of eastern quadrangle border, $1.0 \mathrm{mi}$ north of southern quadrangle border, on northwestern side of right-angle bend in North Carolina State Road 1149, 0.30 mi southwest of main railroad crossing in Teachey, in southeastern 1/9th of map area (latitude $34.7645^{\circ} \mathrm{N}$., longitude $78.0108^{\circ} \mathrm{W}$.). Surface elevation $69 \mathrm{ft}$.

\section{LITHOLOGY}

DEPTH, IN FEET

Road fill $0-1$

\section{UNCONFORMITY}

\section{Charles City Formation}

Sand, very fine to fine, silty, clayey;

olive gray (5Y 4/2) grading down through

olive gray (5Y 4.5/2) (2-4 ft) and through

light olive brown (5Y 5/4) (4-4.5 ft) back

to olive gray $(5 Y 4 / 2)$.....

Silt, very clayey, stiff, sticky; yellowish orange

(10YR 5/6) with light-olive-gray (5Y 6/1) streaks

grading to medium greenish gray ( $5 G Y 5 / 1)$.

Sand, very fine to fine, well-sorted, silty, medium-

greenish-gray ( $5 G Y 5 / 1)$; contains approximately

1 percent very fine, dark, heavy minerals

\section{Donoho Creek Formation}

Sand; fine grading down to fine to medium, dominantly fine; silty; dark greenish gray

(5GY 4/1); medium fraction subrounded to

rounded*

Sand, fine, silty, variably clayey, micaceous, calcareous, dusky-greenish-gray (5GY 3/1);

sparse thin oyster shells*.

\section{Base of Charles City Formation:}

\section{Bottomed in Donoho Creek Formation}

*Recovered an Upper Cretaceous (Campanian) calcareous nannofossil Zone CC 22c(?) assemblage at $23 \mathrm{ft}$ and a Zone CC 22a/b assemblage at $40 \mathrm{ft}$ (Jean M. Self-Trail, USGS, oral commun., 2008). 
RH-21-08: $7.18 \mathrm{mi}$ west of eastern quadrangle border, $8.00 \mathrm{mi}$ north of southern quadrangle border, $200 \mathrm{ft}$ north of intersection of unnumbered dirt road and North Carolina State Road 1117, $0.05 \mathrm{mi}$ east of western quadrangle border, in northwestern $1 / 9$ th of map area (latitude $34.8661^{\circ} \mathrm{N}$., longitude $78.1240^{\circ} \mathrm{W}$.). Surface elevation $118 \mathrm{ft}$.

\section{LITHOLOGY}

DEPTH, IN FEET

\section{Waccamaw Formation, Bahramsville unit}

Sand, fine to medium, clean, light-yellowishbrown (10YR 6/4).

Sand, fine, silty, clayey, dark-yellowish-

orange (10YR 6/6)

Sand, fine, silty, slightly clayey, pale-yellowish-

brown (10YR 6/2); lower contact gradational

Sand, fine to coarse, poorly sorted, silty; pale orange $(10 Y R 7 / 2)$ grading down to very pale orange $(10 Y R$ 8/2)

Sand, very fine to medium, poorly sorted, clayey, silty, stiff, sticky; dark yellowish orange (10YR 6/6) grading down to pale yellowish gray $(5 Y 8 / 2)$

Sand, very fine to medium, poorly sorted, very silty, slightly clayey, yellowish-orange (10YR 7/6)

Sand; fine grading down to fine to medium; silty; clayey; medium orange (10YR 7/8)

Sand, fine to coarse, poorly sorted, silty, clayey, medium-brown (5YR 4/6); abundant rounded quartz granules .

\section{UNCONFORMITY}

\section{Tar Heel Formation}

Sand, fine, silty, dark-yellowish-orange (10YR 6.5/6);

grades down to very fine to fine, micaceous, silty, pale-brown (5YR 6/6) sand....

Sand, very fine to fine, silty, micaceous, darkolive-gray ( $5 Y 3 / 1)$; grades down to very fine, clayey, silty, dark-olive-gray (5Y 3/1) sand; stringers of light-gray ( $N 7)$, very fine sand $31-41$

Base of Waccamaw Formation, Bahramsville unit: $+100 \mathrm{ft}$ above sea level

\section{Bottomed in Tar Heel Formation}




\section{Rowan Quadrangle}

RO-1-08: $5.64 \mathrm{mi}$ west of eastern quadrangle border, $0.99 \mathrm{mi}$ north of southern quadrangle border, on western side of unnumbered dirt road 0.42 mi north-northwest of Salem Cemetery, in southwestern 1/9th of map area (latitude $34.5142^{\circ} \mathrm{N}$., longitude $78.3476^{\circ} \mathrm{W}$.). Surface elevation $50 \mathrm{ft}$.

\section{LITHOLOGY}

DEPTH, IN FEET

\section{Dune sand}

Sand, fine to medium, slightly silty; pale yellowish brown $(10 Y R$ 6/2) grading rapidly down to dark orange $(10 Y R 6 / 8)$...

Sand, fine to medium, slightly silty, soft; pale grayish

orange (10YR 8/4) grading down through brown (5YR 4/2)

$(1.5-2 \mathrm{ft})$, pale grayish orange pink (5YR 8/2) $(2-2.5 \mathrm{ft})$,

pale brown (5YR 6/2) (2.5-3.5 ft), yellowish brown

$(10 Y R 3 / 2)(3.5-6 \mathrm{ft})$, and medium brown (5YR 4/4)

(6-8 ft) to medium brownish gray (5YR 5/1)

Sand; fine to medium, dominantly fine; slightly feldspathic;

slightly silty; thixotropic; yellowish gray (5Y 7/2)

\section{Shirley Formation}

Sand; fine to medium with some coarse grains; angular to subangular; slightly micaceous;

yellowish gray ( $5 Y 7 / 2$ ); subrounded to rounded quartz granules and pebbles up to $0.5 \mathrm{~cm}$ in diameter increasing in abundance downward

\section{UNCONFORMITY}

\section{Chuckatuck Formation}

Sand, very fine to fine, silty, clayey, micaceous, medium-olive-gray (5Y 5/1); wood fragments

Sand, dominantly very fine to fine, silty, very clayey, micaceous, stiff, dark-olive-gray

(5Y 3/1); carbonized wood streaks .

Silt, sandy (very fine), very clayey, dense, dark-

olive-gray (5Y 3/1)

Sand, very fine to fine, silty, slightly clayey, dense;

dark olive gray (5Y 3/1) grading down in basal foot to dark grayish green (10G 5/2); rounded, dusky-brown (5YR 2/2) wood clasts up to $3 \mathrm{~cm}$ in diameter concentrated at base 


\section{Bladen Formation}

Sand, very fine, silty, very clayey; olive gray

(5Y 4/1) grading down to pale olive gray (5Y 7/1)

Sand, very fine to fine, silty, clayey, slightly

micaceous, dense, olive-gray (5Y 4/1)

45-46

Base of dune sand:

Base of Shirley Formation:

Base of Chuckatuck Formation:
$+33 \mathrm{ft}$ above sea level

$+18 \mathrm{ft}$ above sea level

+6 ft above sea level

\section{Bottomed in Bladen Formation}


RO-2-08: $5.27 \mathrm{mi}$ west of eastern quadrangle border, $4.71 \mathrm{mi}$ north of southern quadrangle border, on southeastern corner of sharp turn in unnumbered dirt road, $0.56 \mathrm{mi}$ west-southwest of the " $\mathrm{C}$ " in "Camp Bay" label on map, in westcentral 1/9th of map area (latitude $34.5686^{\circ} \mathrm{N}$., longitude $78.3501^{\circ} \mathrm{W}$.). Surface elevation $45 \mathrm{ft}$.

\section{LITHOLOGY}

DEPTH, IN FEET

\section{Dune sand}

Sand, fine to medium, subangular to subrounded, soft, slightly silty; pale brown (5YR 5/2) grading down to pale grayish orange (10YR 8/4) with dark-yellowish-orange (10YR 6/6) mottles

Sand, fine to medium, subangular to subrounded, soft, slightly silty, yellowish-gray (5Y 7/4); abrupt basal contact

\section{Shirley Formation}

Sand; very fine to medium, dominantly fine; silty grading down to silty and clayey; dusky yellowish brown (10YR 2/2); roots

Sand, very fine to medium; medium fraction subrounded; humic; dusky yellowish brown (10YR 2/2); abundant dark-reddish-brown (5YR 3/4) roots

Sand, very fine to medium; fine fraction angular and medium fraction angular to subrounded; slightly silty; humic; medium brown (5YR 3.5/4) grading down to dark yellowish brown (10YR 3/2).

Sand, fine to coarse, angular to subangular, slightly silty; yellowish brown (10YR 5/2) grading down to olive gray (5Y 4/2); sparse subangular to subrounded quartz pebbles up to $1 \mathrm{~cm}$ in diameter ....

\section{Bladen Formation}

Silt, clayey, micaceous, dark-greenish-gray (5GY 3/1); interbedded with thin laminae of clean, very fine to fine sand .....

Sand, very fine, silty, micaceous, dark-greenishgray (5GY 3/1); dusky-brown (5YR 2/2) wood clast at $35 \mathrm{ft}$. 
Sand, fine to coarse, subrounded, dark-greenish-

gray (5GY 3/1); clayey and silty at top but cleaner

downward; fine to medium glauconite grains;

probably near base of unit.

Base of dune sand:

Base of Shirley Formation:

+41 ft above sea level

$+17 \mathrm{ft}$ above sea level

Bottomed in Bladen Formation 
RO-3-08: $5.26 \mathrm{mi}$ west of eastern quadrangle border, $5.01 \mathrm{mi}$ north of southern quadrangle border, on northern side of sharp bend in unnumbered dirt road, 0.18 mi north-northwest of the "C" in "Camp Bay" label on map, in west-central 1/9th of map area (latitude $34.5726^{\circ} \mathrm{N}$., longitude $78.3417^{\circ} \mathrm{W}$.). Surface elevation $67 \mathrm{ft}$.

\section{LITHOLOGY}

DEPTH, IN FEET

\section{Dune sand}

Sand, fine to medium, subangular to subrounded, clean, soft; dark yellowish brown (10YR 3/2)

grading down through grayish orange pink (5YR 7/2)

to dark yellowish brown (10YR 3/2)

Sand, fine to medium, subangular to subrounded, clean, soft, very humic; abundant roots; very

dark red (10YR 1/2); lower contact gradational

Sand, fine to medium, subangular to subrounded, clean, soft, dark-yellowish-orange (10YR 6/5)....

\section{UNCONFORMITY}

\section{Chuckatuck Formation}

Sand; very fine to fine, grades down to fine to medium; clayey; silty; slightly sticky; light olive gray (5Y 6/1)

Sand, very fine to medium, poorly sorted, clayey, silty, slightly sticky; brownish gray (5YR 4/1) intermingled with light olive gray (5Y 6/2);

lower contact somewhat gradational.....

Sand, fine to very coarse, subangular to subrounded, very poorly sorted, clean to slightly silty, soft; light yellowish brown (10YR 6/4) grading down to pale yellowish brown (10YR 5/2).

Sand, medium to very coarse, poorly sorted, paleyellowish-brown (10YR 5/2); subrounded quartz pebbles up to $1 \mathrm{~cm}$ in diameter increasingly abundant downward

\section{UNCONFORMITY}

\section{Bladen Formation}

Sand; very fine grading down to very fine to fine; clayey; silty; dark olive gray ( $5 Y 3 / 1)$; lower contact somewhat gradational 
Sand, very fine to fine, silty, clayey, micaceous,

dark-greenish-gray (5GY 4/1); scattered

dusky-yellowish-brown (10YR 2/2) lignite fragments

39-41

Base of dune sand:

Base of Chuckatuck Formation:

+52 ft above sea level

$+36 \mathrm{ft}$ above sea level

\section{Bottomed in Bladen Formation}


RO-4-08: $3.50 \mathrm{mi}$ west of eastern quadrangle border, $6.93 \mathrm{mi}$ north of southern quadrangle border, $100 \mathrm{ft}$ southwest of North Carolina Highway 210, 1.68 mi due south of northern quadrangle border, in north-central 1/9th of map area (latitude $34.5989^{\circ} \mathrm{N}$., longitude $78.3094^{\circ} \mathrm{W}$.). Surface elevation $33 \mathrm{ft}$.

\section{LITHOLOGY}

DEPTH, IN FEET

\section{Shirley Formation}

Sand, fine, well-sorted; scattered subrounded

to rounded medium grains; slightly silty; micaceous;

dark yellowish brown (10YR 4/2) grading rapidly

down to pale grayish orange (10YR $8 / 4)$.

Sand, very fine to fine, silty, slightly clayey; dusky

yellowish orange (10YR 5/6) grading down to dark

yellowish orange (10YR 6/6); lower contact

somewhat gradational

Sand, very fine, clayey, silty, stiff, sticky, yellowish-

brown (10YR 5/2).

Sand, fine to coarse, poorly sorted, slightly silty; pale yellowish gray (5Y 8/2) grading down through dark orange (10YR 6/8) to brown (10YR 4/6).

Clay, silty, dark-orange (10YR 6/8); 2 in. thick at 9

Sand, medium to coarse, clean; very pale orange (10YR 8/2) grading down to pale yellowish brown (10YR 6/2)

\section{UNCONFORMITY}

\section{Chuckatuck Formation}

Silt, clayey, sticky, woody; grayish brown (5YR 3/2) grading down to medium grayish brown (5YR 4/2); lower contact somewhat gradational

Sand, fine to medium, silty, soft, yellowish-brown (10YR 5/2); coarsens down to layer below.

Sand, medium to very coarse, poorly sorted, yellowishbrown (10YR $5 / 2)$; gravelly with subrounded to rounded quartz pebbles up to $3 \mathrm{~cm}$ in diameter 


\section{Tar Heel Formation}

Clay, silty, dark-greenish-gray (5GY 4/1);

lumps of dusky-yellowish-brown (10YR 2/2) lignite

$23-26$

Base of Shirley Formation:

$+23 \mathrm{ft}$ above sea level

Base of Chuckatuck Formation:

$+10 \mathrm{ft}$ above sea level

Bottomed in Tar Heel Formation 
RO-5-08: $2.12 \mathrm{mi}$ west of eastern quadrangle border, $2.06 \mathrm{mi}$ north of southern quadrangle border, at end of unnumbered dirt road $0.18 \mathrm{mi}$ north of North Carolina State Road 1548, $0.47 \mathrm{mi}$ northwest of intersection of North Carolina State Road 1548 and North Carolina Highway 210 in southeastern 1/9th of map area (latitude $34.5298^{\circ} \mathrm{N}$., longitude $78.2867^{\circ} \mathrm{W}$.). Surface elevation $35 \mathrm{ft}$.

\section{LITHOLOGY}

DEPTH, IN FEET

\section{Shirley Formation}

Silt, sandy (very fine), clayey, stiff; yellowish brown

(10YR 4/2) grading to yellowish orange (10YR 7/6)

Silt, very clayey, stiff, sticky, dense; dark yellowish

orange (10YR 6/6) with yellowish-gray (5Y 7/2) mottles

grading down to yellowish gray $(5 Y 7 / 2)$ with

dark-yellowish-orange (10YR 6/6) mottles; lower contact

somewhat gradational

Silt, very clayey, stiff, sticky, dense; pale yellowish

gray $(5 Y 8 / 2)$ grading down to very pale brown

(5YR 6/2)

Peat, silty, dusky-yellowish-brown (5YR 1/2);

abundant wood fragments

Sand; fine to medium grading down to medium to coarse

with rounded quartz granules and pebbles up to $0.5 \mathrm{~cm}$

in diameter; silty; soft; dark yellowish brown

(10YR 3/2) grading down to dark yellowish brown

(10YR 4/2)

\section{Bladen Formation}

Sand; very fine to fine with scattered medium grains; silty; clayey; dark greenish gray (5GY 4/1);

\section{Base of Shirley Formation:}

$+12 \mathrm{ft}$ above sea level

\section{Bottomed in Bladen Formation}


RO-6-08: $2.28 \mathrm{mi}$ west of eastern quadrangle border, $3.58 \mathrm{mi}$ north of southern quadrangle border, $300 \mathrm{ft}$ southwest of unnumbered road along northeast rim of Big Bay, 0.10 mi northwest of Moore Swamp Church, in east-central 1/9th of map area (latitude $34.5521^{\circ} \mathrm{N}$., longitude $78.2898^{\circ} \mathrm{W}$.). Surface elevation $58 \mathrm{ft}$.

\section{LITHOLOGY}

DEPTH, IN FEET

\section{Dune sand}

Sand, fine to medium, slightly silty, soft; grayish brown

(5YR 3/2) with yellowish-brown (10YR 5/2) mottles grading

down to light yellowish brown (10YR 6/4) with dark-

yellowish-brown (10YR 4/4) mottles

Sand, fine to medium, slightly silty, soft, humic; pale

grayish orange (10YR 8/4) grading down through

dark yellowish orange (10YR 6/6) (4-5 ft) to

pale yellowish brown (10YR 7/2)

Sand, fine to medium, silty, very humic; dusky

yellowish brown (10YR 2/2) grading down to dark

yellowish brown (10YR 4/4)

UNCONFORMITY

\section{Chuckatuck Formation}

Sand, fine, silty, humic, yellowish-brown (10YR 3/2)

Sand, fine to medium, silty, humic; light yellowish

brown (10YR 6/4) grading down through yellowish

orange (10YR 7/6) (9-9.5 ft), dusky yellowish

brown (10YR 2/2) (9.5-10 ft), and yellowish

orange (10YR 7/6) (10-10.5 ft) to dusky

yellowish brown $(10 Y R 2 / 2)$

Sand, fine to medium, clean; grades down to medium to

very coarse; poorly sorted; scattered rounded

and polished quartz granules; pale yellowish brown

(10YR 7/2); basal 3 in. becomes silty and yellowish gray

(5Y 8/1); contains rounded quartz pebbles up to 5

$\mathrm{cm}$ in diameter

$11-17$

\section{UNCONFORMITY}

\section{Bladen Formation}

Sand, very fine to fine, silty, clayey, micaceous, dense, slightly sticky, dusky-greenish-gray

Base of dune sand:

Base of Chuckatuck Formation:

\section{Bottomed in Bladen Formation}

$+50 \mathrm{ft}$ above sea level

$+41 \mathrm{ft}$ above sea level 


\section{St. Pauls Quadrangle}

SP-1-06: $5.79 \mathrm{mi}$ west of eastern quadrangle border, $1.77 \mathrm{mi}$ north of southern quadrangle border, on southern side of abandoned house at end of unnumbered dirt road, $0.26 \mathrm{mi}$ southwest of 157-ft spot elevation at junction of unnumbered dirt road and North Carolina State Road 1939, in southwestern 1/9th of map area (latitude $34.7760^{\circ} \mathrm{N}$., longitude $78.9764^{\circ} \mathrm{W}$.). Surface elevation $157 \mathrm{ft}$.

\section{LITHOLOGY}

DEPTH, IN FEET

\section{Varina Grove unit}

Sand, fine to medium, silty, clayey; dark yellowish brown $(10 Y R 4 / 2)$ grading rapidly down to light yellowish brown (10YR 6/4)

Sand, fine to medium, silty, clayey; pale yellowish brown $(10 Y R 6 / 2)$ grading down to dark yellowish orange $(10 Y R 6 / 6)$......

Sand, fine, silty; pale brownish gray (5YR 7/1)

grading down to yellowish gray ( $5 Y$ 8/1); basal

4 in. bright orange (10YR 6/8).

Sand, very fine to fine, silty, clayey, medium-

dark-gray ( $N$ 4).

Sand, fine to medium, silty, soft, yellowish-gray

(5Y 8/1); lower contact gradational

Sand, fine to coarse, subangular to subrounded, poorly sorted, soft, yellowish-gray (5Y 8/1);

lower contact gradational

Sand, fine to coarse, poorly sorted, silty, clayey; very light gray ( $N$ 7.5) grading down through dark gray $(N 3)$ to medium gray ( $N 5.5)$; contains subangular quartz pebbles up to $2 \mathrm{~cm}$ in maximum diameter

\section{UNCONFORMITY}

\section{Tar Heel Formation}

Silt, clayey, sandy (very fine), pale-olive-gray

(5Y 6/2); subrounded wood clasts up to

$2.5 \mathrm{~cm}$ in diameter.

Silt, clayey, sandy (very fine), micaceous, carbonaceous, dense, stiff, brownish-gray

\section{Base of Varina Grove unit:}

\section{$+132 \mathrm{ft}$ above sea level}

\section{Bottomed in Tar Heel Formation}


SP-2-07: $1.17 \mathrm{mi}$ west of eastern quadrangle border, $1.02 \mathrm{mi}$ north of southern quadrangle border, $100 \mathrm{ft}$ southsouthwest of North Carolina State Road 1006, 0.04 mi west of intersection of North Carolina State Roads 1006 and 1928, along outer edge of southwestern rim of Powers Bay, in southeastern 1/9th of map area (latitude $34.7650^{\circ} \mathrm{N}$., longitude $78.8951^{\circ} \mathrm{W}$.). Surface elevation $149 \mathrm{ft}$.

\section{LITHOLOGY}

DEPTH, IN FEET

\section{Varina Grove unit}

Sand, fine to medium, dominantly fine, silty; grayish brown $(5 Y R 3 / 2)$ grading rapidly down to dark yellowish orange (10YR 6/6).

Sand, very fine to fine, silty, slightly clayey; dark yellowish orange (10YR 6/6) with pale-brownish-gray (5YR 7/1) mottles in basal foot

Sand, very fine to fine, clayey, silty, stiff, slightly sticky, yellowish-orange

(10YR 7/6)

Sand, very fine to fine, silty, yellowishgray $(5 Y 7 / 2)$

Sand; very fine to fine grading down to fine to medium; silty; pale bluish gray (5B 8/1)

Sand; fine to medium grading down to medium to very coarse; poorly sorted;

dark gray $(N 3)$; subangular

to subrounded quartz granules

\section{Tar Heel Formation}

Clay, silty, very stiff, greasy, dense, medium-brownish-gray (5YR 5/1).

Base of Varina Grove unit:

$+131 \mathrm{ft}$ above sea level

\section{Bottomed in Tar Heel Formation}


SP-3-07: $5.68 \mathrm{mi}$ west of eastern quadrangle border, $7.32 \mathrm{mi}$ north of southern quadrangle border, on northern side of unnumbered dirt road on eastern edge of field, $0.30 \mathrm{mi}$ northeast of intersection of U.S. Highway 301 and North Carolina State Road 1726, in northwestern 1/9th of map area (latitude $34.8560^{\circ} \mathrm{N}$., longitude $78.9744^{\circ} \mathrm{W}$.). Surface elevation $175 \mathrm{ft}$.

\section{LITHOLOGY}

DEPTH, IN FEET

\section{Dune sand}

Sand; very fine to fine with scattered medium grains; silty; slightly clayey; pale grayish orange (10YR $8 / 4$ ) grading rapidly down to dark yellowish orange (10YR 6/6).

Sand; very fine to fine with scattered medium grains; silty; clayey; dark yellowish orange (10YR 6/6) grading down to light brown

Sand; very fine to fine with scattered medium grains; silty; clayey; pale reddish brown (10R 5/4) grading down to grayish orange pink (5YR 7/2).

Sand; very fine to fine with scattered medium grains grading down to fine to medium; silty; clayey; pale brown (5YR 7/4)

\section{UNCONFORMITY}

\section{Varina Grove unit}

Sand, very fine, very clayey, silty, very

stiff, dense; pale brownish gray (5YR 7/1)

with light-reddish-brown (10R 5/6) mottles

Sand; fine to coarse, dominantly medium;

poorly sorted; silty; pale brown (5YR 7/4);

reddish-pink (5R 6/4) clayball or clay lens at $26 \mathrm{ft}$.

Silt, very clayey, sandy (very fine), sticky, yellowish-orange (10YR 7/6)

Silt, sandy (very fine), slightly clayey; grades down through very fine to fine sand to fine sand; silty and slightly clayey; dark orange (10YR $6 / 8)$

Sand, fine, silty, pale-yellowish-orange (10YR 8/6)

Sand; fine to medium, dominantly fine;

clean; light reddish orange (10R 7/6)

grading down to yellowish orange (10YR 7/6)

at $49 \mathrm{ft}$; lower contact gradational. 
Sand, fine to coarse, dominantly medium, poorly sorted, clean; pale grayish orange

(10YR 8/4) grading down in basal 6 in.

to pale brown (5YR 6/6)

Silt, very clayey, sandy (very fine), pale-

yellowish-brown (10YR 7/2).

Sand, medium to coarse, yellowish-gray

(5Y 8/1); contains approximately 1 percent

very fine, dark, heavy minerals...

$57-70$

\section{Tar Heel Formation}

Sand, fine to medium, silty, clayey,

micaceous, dense, medium-gray $(N 5)$;

abundant fragments of wood

and two carbonized logs

Clay, silty, greasy, very dense, dark-

olive-gray ( $5 Y 3 / 1$ ); pyrite

lumps up to $1 \mathrm{~cm}$ in diameter.

Base of dune sand:

Base of Varina Grove unit:

$+160 \mathrm{ft}$ above sea level

$+105 \mathrm{ft}$ above sea level

\section{Bottomed in Tar Heel Formation}


SP-4-07: $3.09 \mathrm{mi}$ west of eastern quadrangle border, $3.78 \mathrm{mi}$ north of southern quadrangle border, $200 \mathrm{ft}$ south of North Carolina State Road 1920, 0.57 mi east-southeast of intersection of North Carolina State Roads 1920 and 1919, $300 \mathrm{ft}$ north of railroad tracks, in central 1/9th of map area (latitude $34.8047^{\circ} \mathrm{N}$., longitude $78.9295^{\circ} \mathrm{W}$.). Surface elevation $155 \mathrm{ft}$.

\section{LITHOLOGY}

DEPTH, IN FEET

\section{Dune sand}

Sand; fine to medium, dominantly fine; clean; grayish brown (5YR 3/2) grading down through grayish orange (10YR 7/4) $(0.5-3.5 \mathrm{ft})$

to yellowish gray (5Y 8/1).

\section{Varina Grove unit}

Sand, fine, silty, slightly clayey, dusky-

yellowish-orange $(10 Y R$ 5/6)

Sand, fine, clayey, silty, light-brown (5YR 5/6)

Sand, fine to medium, very clayey and silty, stiff, sticky; medium gray $(N 5)$, reddish brown $(10 R 4 / 8)$, and brownish gray (5YR 4/1) with yellowish-gray (5Y 8/1) mottles.

Sand, fine, silty, pale-brown (5YR 7/4) $13-16$

Sand; fine and fine to medium, interbedded; silty; yellowish orange (10YR 7/6) grading down to grayish orange (10YR 7/4) at $36 \mathrm{ft}$; pinkish gray (5YR 8/1) clayball at $36 \mathrm{ft}$ $16-38$

\section{UNCONFORMITY}

\section{Chowan River Formation, Coharie Member}

Sand, fine to medium, silty, very kaolinitic, micaceous, yellowish-gray (5Y 8/1).

Sand, fine to coarse, poorly sorted, slightly silty,

kaolinititic, pinkish-gray (5YR 8/1) $54-56$

Sand; fine grading down through medium to coarse then to fine; silty; very kaolinitic; micaceous; yellowish gray (5Y 8/1).

Sand; fine to medium grading down to fine to coarse; silty; kaolinitic; pinkish gray (5YR 8/1); lower contact somewhat gradational

Sand, medium to very coarse, poorly sorted, slightly silty, soft; medium red ( $5 R 5 / 6)$ grading down in basal foot to light brown (5YR 5/6) 


\section{Tar Heel Formation}

Clay, silty, stiff, sticky, weathered; grayish orange pink (5YR 6/2) with yellowishorange $(10 Y R$ 7/6) mottles.

Clay, silty, stiff, dense, olive-black

(5Y 2/1); black carbonized wood

fragments and lumps of pyrite.

Sand, fine to medium, silty, slightly clayey, micaceous; dark yellowish brown (10YR 4/2)

with scattered dark-gray $(N 3)$ clay laminae

Sand, fine to medium, micaceous, medium-gray

$(N 5)$; carbonized wood fragments..... 89-91

Base of dune sand:

Base of Varina Grove unit:

Base of Chowan River Formation, Coharie Member:

Bottomed in Tar Heel Formation
$+150 \mathrm{ft}$ above sea level

$+117 \mathrm{ft}$ above sea level

$+73 \mathrm{ft}$ above sea level 
SP-5-07: $1.42 \mathrm{mi}$ west of eastern quadrangle border, $6.99 \mathrm{mi}$ north of southern quadrangle border, $50 \mathrm{ft}$ south of North Carolina State Road 2257, 0.06 mi east-southeast of junction of North Carolina State Roads 2257 and 2252, in northeastern $1 / 9$ th of map area (latitude $34.8515^{\circ} \mathrm{N}$., longitude $78.8996^{\circ} \mathrm{W}$.). Surface elevation $160 \mathrm{ft}$.

\section{LITHOLOGY}

DEPTH, IN FEET

\section{Varina Grove unit}

Sand; fine to medium, dominantly fine; clean; brownish gray (5YR 4/1) grading rapidly

down to yellowish gray $(5 Y 7 / 2)$.

Sand, fine to medium, dominantly fine, silty, slightly clayey, stiff; dark yellowish orange (10YR 6/6) grading down to light yellowish brown

(10YR 6/4) with light-gray ( $N$ 7.5) and

light-brown (5YR 5/6) mottles.

Sand; fine to medium grading down to medium to

coarse; subangular; slightly silty and clayey;

stiff; pale orange (105YR 8/8) grading down

to pale grayish orange (10YR 8/4); lower contact

gradational

Sand, fine to medium, subangular, silty, pale-

grayish-orange-pink (5YR 7/4); lower contact gradational

Sand, medium to coarse, subangular, silty,

very pale orange (10YR $8 / 2)$; lower contact gradational

Sand, medium to very coarse, poorly sorted, angular to subangular, very pale orange

(10YR 8/2); rounded quartz pebbles

up to $3 \mathrm{~cm}$ in diameter

\section{UNCONFORMITY}

\section{Tar Heel Formation}

Clay, dense, sticky; scattered mica flakes

and black wood fragments; medium grayish

pink ( $5 R 7 / 2)$ with dark-yellowish-orange

(10YR 6/6) mottles grading down through grayish

orange pink (5YR 7/2) (24-26 ft) to dark gray $(N 3)$.

Sand, fine to medium, silty, slightly micaceous, medium-dark-gray ( $N$ 4); black

scattered wood fragments.

\section{Bottomed in Tar Heel Formation}




\section{Singletary Lake Quadrangle}

SI-1-07: $6.10 \mathrm{mi}$ west of eastern quadrangle border, $1.99 \mathrm{mi}$ north of southern quadrangle border, on northern side of unnumbered dirt road, $50 \mathrm{ft}$ west of North Carolina State Road 1715 and $0.77 \mathrm{mi}$ north-northeast of junction of North Carolina State Roads 1715 and 1712, in southwestern 1/9th of map area (latitude $34.5290^{\circ} \mathrm{N}$., longitude $78.4813^{\circ} \mathrm{W}$.). Surface elevation $105 \mathrm{ft}$.

\section{LITHOLOGY}

DEPTH, IN FEET

\section{Waccamaw Formation, Moorings unit}

Sand, very fine to fine, clean, grayish-orange

(10YR 7/4)

Sand, fine, slightly silty and clayey, stiff; yellowish orange (10YR 7/6) grading down to yellowish gray $(5 Y 7 / 2)$ at $4 \mathrm{ft}$.

Sand, fine to medium, silty, yellowish-gray $(5 Y 7 / 2)$

Sand, very fine to fine, silty; orange (10YR 7/8)

with very light gray $(N$ 8) blotches grading

down through yellowish gray ( $5 Y$ 8/1) (8.5-9 ft),

grayish orange (10YR 7/4) (9-12 ft), and

pinkish gray (5YR 8/1) $(12-13 \mathrm{ft})$ to

pale yellowish brown (10YR 6/2).

\section{Waccamaw Formation, Bahramsville unit}

Silt, sandy (very fine), clayey, yellowish-orange

(10YR 7/6)

Sand, very fine to fine; pinkish gray (5YR 8/1)

grading down through pale yellowish orange (10YR 8/6)

(16-19 ft) to yellowish orange (10YR 7/6).

Silt, very clayey, sandy (very fine); upper foot yellowish gray (5Y 7/2) grading rapidly down to medium gray $(N 5)$.

\section{Waccamaw Formation, James City Member}

Sand, fine to coarse, poorly sorted, very silty and clayey, stiff, medium-greenish-gray (5GY 5/1);

Sand; medium to coarse grading down to fine to coarse; poorly sorted; medium light gray $(N 6)$ grading down to medium olive gray ( $5 Y 5 / 1)$; sparse shells, including oysters .....

Sand, very fine to fine, clayey, silty, mediumgray $(N 5)$ 


\section{Bladen Formation}

Sand, very fine to fine, silty, clayey; top

3 in. yellowish gray ( $5 Y 8 / 1)$ grading

down rapidly to dark brownish gray (5YR 3/1);

abundant fine mica; very fine sand-filled burrows

about $1 \mathrm{~cm}$ in diameter.

Base of Waccamaw Formation, Moorings unit:

Base of Waccamaw Formation, Bahramsville unit:

Base of Waccamaw Formation, James City Member:
$+99 \mathrm{ft}$ above sea level

$+61 \mathrm{ft}$ above sea level

$+52 \mathrm{ft}$ above sea level

\section{Bottomed in Bladen Formation}


SI-2-07: $4.27 \mathrm{mi}$ west of eastern quadrangle border, $1.12 \mathrm{mi}$ north of southern quadrangle border, on northern side of unnumbered dirt road, $100 \mathrm{ft}$ east of junction of North Carolina State Road 1712 and North Carolina Highway 87, in south-central 1/9th of map area (latitude $34.5160^{\circ} \mathrm{N}$., longitude $78.4493^{\circ} \mathrm{W}$.). Surface elevation $123 \mathrm{ft}$.

\section{LITHOLOGY}

DEPTH, IN FEET

\section{Waccamaw Formation, Moorings unit}

Sand, fine, slightly silty; pale yellowish brown $(10 Y R$ 6/2) grading down through pale grayish orange $(10 Y R$ 8/4) $(0.5-2$

$\mathrm{ft})$, very dark yellowish orange (10YR 5/6)

$(2-2.5 \mathrm{ft})$, and very pale orange

$(10 Y R$ 8/2) (2.5-3 ft) to yellowish

orange (10YR 7/6); less than 1 percent

very fine grained, dark, heavy minerals;

lower contact gradational

Sand, fine, slightly silty; pale brown (5YR 5/2)

grading down through grayish brown (5YR 3/2)

(9-11 ft), dark brown (5YR 2/4), grayish orange

pink (5YR 7/2), and dark brown (5YR 2/4)

(11-13 ft) to yellowish gray (5Y 8/1); $1-2$ percent

very fine grained, dark, heavy minerals

Sand, fine to medium, subrounded; yellowish gray (5Y 8/1) with pale grayish orange (10YR 8/4)

streaks in basal $3 \mathrm{ft}$; $1-2$ percent very fine grained, dark, heavy minerals; lower contact gradational

Sand, medium to very coarse, subrounded to round, poorly sorted, pebbly, yellowishorange (10YR 7/6)

\section{Waccamaw Formation, Bahramsville unit}

Silt, very clayey, sandy (very fine); wood fragment in top foot; light brown (5YR 5/6) grading down through pale yellowish brown (10YR 6/2) in upper foot, then medium light gray $(N 6)$ grading down to medium light gray $(N 6)$ with olive-black (5Y 2/1) mottles at $44 \mathrm{ft}$..

\section{Waccamaw Formation, James City Member}

Sand, fine to coarse, poorly sorted, silty, clayey; greenish gray ( $5 G 6 / 1)$ grading down to medium gray ( $N$ 5); lower contact abrupt 


\section{Bladen Formation}

Silt, very clayey, sandy (very fine), stiff, dark-

olive-gray (5Y 3/1), about 3 in. recovered...

at 61

Base of Waccamaw Formation, Moorings unit:

Base of Waccamaw Formation, Bahramsville unit:

Base of Waccamaw Formation, James City Member:
+93 ft above sea level

$+71 \mathrm{ft}$ above sea level

+62 ft above sea level

Bottomed in Bladen Formation 
SI-3-07: $1.58 \mathrm{mi}$ west of eastern quadrangle border, $1.47 \mathrm{mi}$ north of southern quadrangle border, on northwestern side of unnumbered dirt road (Wendell Drive), $0.57 \mathrm{mi}$ northeast of junction of Wendell Drive and North Carolina Highway 53, in southeastern $1 / 9$ th of map area (latitude $34.5215^{\circ} \mathrm{N}$., longitude $78.4021^{\circ} \mathrm{W}$.). Surface elevation $41 \mathrm{ft}$.

\section{LITHOLOGY}

DEPTH, IN FEET

\section{Dune sand}

Sand, fine to medium, subangular to subrounded; grayish brown (10YR 3/2) grading down through light brownish gray (5YR 6/1) to grayish orange (10YR 7/4)

Sand, fine to medium, subangular to subrounded; very pale orange (10YR $8 / 2)$ grading down through dusky yellow (5Y 6/4) (2-4 ft)

to dusky brown (5YR 2/2) ...

Sand; very fine to fine, dominantly fine; subangular to subrounded; humic; medium brown (5YR 4/4)

\section{UNCONFORMITY}

\section{Alluvium}

Sand; medium to coarse grading down to medium to very coarse at $14 \mathrm{ft}$; poorly sorted with subrounded to rounded quartz pebbles up to $1 \mathrm{~cm}$ in diameter; medium yellowish brown (10YR 5/4)

Sand, medium to coarse, silty, olive-gray ( $5 Y 4 / 1)$;

contains detrital clasts of reworked Tar Heel

Formation

Sand, medium to coarse, clean, greenish-gray (5G 6/1). $36-38$

\section{UNCONFORMITY}

\section{Tar Heel Formation}

Sand, very fine to fine, silty, clayey, micaceous, dense, olive-gray (5Y 4/1); abundant

lumps of grayish-brown (5YR 3/2) and very dark orange (10YR 7/8) lignite; occasional thin layers of fine to medium sand and very clayey silt

Base of dune sand:

Base of alluvium:

\section{Bottomed in Tar Heel Formation}


SI-4-07: $3.49 \mathrm{mi}$ west of eastern quadrangle border, $4.38 \mathrm{mi}$ north of southern quadrangle border, $300 \mathrm{ft}$ northeast of North Carolina Highway 53, 0.16 mi northwest of the "L" in "Lagoon" map label, in central 1/9th of map area (latitude $34.5633^{\circ} \mathrm{N}$., longitude $78.4360^{\circ} \mathrm{W}$.). Surface elevation $51 \mathrm{ft}$.

\section{LITHOLOGY}

DEPTH, IN FEET

\section{Dune sand}

Sand, fine to medium, subangular to subrounded; grayish brown (5YR 3/2) grading down at $0.5 \mathrm{ft}$ to grayish orange $(10 Y R$ 7/4)

Sand; fine to medium grading down to fine; soft; dusky yellowish orange (10YR 5/6) grading

down at $3 \mathrm{ft}$ to very pale orange (10YR 8/2) .....

Sand, fine; pale grayish yellow (10YR 8/4)

grading down through dusky yellowish orange

$(10 Y R 5 / 6)(7-8 \mathrm{ft})$ to dark yellowish

orange (10YR 6/6)

\section{UNCONFORMITY}

\section{Older alluvium}

Paleosol, sand, very fine to fine, silty, clayey;

0.5 -in.-thick zone of olive gray

(5Y 4/2) over yellowish gray (5Y 7/2)

Sand, fine to coarse, poorly sorted, silty, yellowish-gray (5Y 8/1).

Sand; medium to coarse grading down to medium to very coarse; poorly sorted with granules of quartz; subrounded; yellowish gray $(5 Y 8 / 1)$...

\section{Shirley Formation}

Sand, fine, silty, light-olive-gray (5Y 6/1); more compacted than layers above; scattered wood fragments.

Wood, dusky-yellow (5Y 6/4) to dark-reddishbrown (5YR 3/4); overlying 3-in.-thick layer of fine to medium, silty, paleyellowish-brown (10YR 7/2) sand 


\section{Tar Heel Formation}

Sand, fine to coarse, poorly sorted;

interbedded with silty clay; dense; dark

olive gray (5Y 3/1); contains dark-brown

(5YR 2/4) lignite.

34-36

Base of dune sand:

Base of older alluvium:

Base of Shirley Formation:

$+40 \mathrm{ft}$ above sea level

$+27 \mathrm{ft}$ above sea level

$+17 \mathrm{ft}$ above sea level

\section{Bottomed in Tar Heel Formation}


SI-5-07: $4.27 \mathrm{mi}$ west of eastern quadrangle border, $1.12 \mathrm{mi}$ north of southern quadrangle border, on eastern side of North Carolina Highway 53, 0.73 mi northwest of the first "S" in "Singletary Lake State Park" label on map, in northwestern 1/9th of map area (latitude $34.6055^{\circ} \mathrm{N}$., longitude $78.4772^{\circ} \mathrm{W}$.). Surface elevation $65 \mathrm{ft}$.

\section{LITHOLOGY}

DEPTH, IN FEET

\section{Dune sand}

Sand, fine, subangular to subrounded, clean, soft; grayish brown (5YR 3/2) grading rapidly down to pale yellowish brown (10YR 7/2).....

Sand, very fine to fine, variably silty, variably humic; grayish brown (5YR 3/2) grading down through yellowish brown (10YR 5/2) (1.5$2 \mathrm{ft})$, dusky brown (10YR 2/2) (2-2.5 ft), and pale pinkish gray $(10 Y R$ 9/1) $(2.5-3 \mathrm{ft})$ to dark brown (5YR 2/4)...

Sand, fine to medium, subangular to subrounded, humic; medium brown (5YR 4/4) grading down through pale yellowish brown (10YR 6/2) to medium yellowish brown (10YR 5/4); very humic in basal foot

\section{UNCONFORMITY}

\section{Chuckatuck Formation}

Peat, sandy (very fine), woody, dark-brown (5YR 2/4).

Sand, very fine to fine; dark yellowish brown

(10YR 4/4) grading down to pale yellowish gray $(5 Y 8 / 2)$

Sand, very fine to fine, silty, clayey, very light gray $(N 9)$

Silt, clayey, sandy (very fine), very finely micaceous, greasy, light-greenish-gray (5G 7/1)...

Sand; very fine to fine grading down to fine; subangular; slightly silty; slightly micaceous; pale olive gray (5Y 7/1); lower contact gradational

Sand; fine to medium grading down to medium to coarse; pale olive gray (5Y 7/1); quartz pebbles up to $1 \mathrm{~cm}$ in diameter 


\section{Tar Heel Formation}

Clay, silty; very fine to fine sand-filled

burrows 0.5 to $1 \mathrm{~cm}$ in diameter; interbedded

with fine to medium sand; micaceous; dark

olive gray (5Y 3/1)

$44-46$

Base of dune sand:

Base of Chuckatuck Formation:

$+48 \mathrm{ft}$ above sea level

$+21 \mathrm{ft}$ above sea level

\section{Bottomed in Tar Heel Formation}


SI-6-07: $1.92 \mathrm{mi}$ west of eastern quadrangle border, $7.66 \mathrm{mi}$ north of southern quadrangle border, on southwestern side of junction of two unnumbered dirt roads at 84 -ft spot elevation, in northeastern 1/9th of map area (latitude $34.5160^{\circ} \mathrm{N}$., longitude $78.4493^{\circ} \mathrm{W}$.). Surface elevation $84 \mathrm{ft}$.

\section{LITHOLOGY}

DEPTH, IN FEET

\section{Dune sand}

Sand; fine to medium, dominantly fine;

subangular to subround; pale grayish

orange pink (5YR 7/2) over dark reddish brown

(5YR 3/4)...

Sand; fine to medium, dominantly fine;

subangular to subrounded; humic; thixotropic;

dusky brown (5YR 2/2) grading down to

dark reddish brown (5YR 3/4) at $4 \mathrm{ft}$

Peat, dark-olive-brown (5Y 2/4);

light-brown (5YR 5/6) wood pieces..

Sand, fine to medium, mostly subrounded,

humic; yellowish brown (10YR 5/2)

grading down to dark yellowish

brown (10YR 4/2) at $21 \mathrm{ft}$; upper part contains

roots from peat bed above.

\section{UNCONFORMITY}

\section{Chuckatuck Formation}

Silt, very clayey, sandy (very fine);

medium gray $(N 5)$ grading down

to yellowish gray (5Y 8/1); lower contact

gradational

Sand, very fine to fine, silty, clayey;

yellowish gray (5Y 8/1) grading down

to brownish gray (5YR 5/1); lower contact

gradational

Sand, fine to medium, clean, thixotropic,

yellowish-gray (5Y 8/1), lower contact gradational

Sand, medium to coarse, clean, thixotropic,

yellowish-gray (5Y 8/1).

Sand; coarse to very coarse, dominantly

very coarse; greenish gray ( $5 G 7 / 1)$;

abundant quartz pebbles up to

$2 \mathrm{~cm}$ in diameter. 


\section{Tar Heel Formation}

Sand, very fine to fine, silty, clayey,

micaceous, dense, sparsely lignitic;

olive gray (5Y 4/1) grading down to

light olive gray (5Y 6/1)

53-56

Base of dune sand:

Base of Chuckatuck Formation:
+59 ft above sea level

+31 ft above sea level

\section{Bottomed in Tar Heel Formation}




\section{Southeast Lumberton Quadrangle}

SL-1-06: $6.18 \mathrm{mi}$ west of eastern quadrangle border, $6.34 \mathrm{mi}$ north of southern quadrangle border, on northern side of public boat ramp parking area, under the "m" in "Public Boat Ramp" label on map, in northwestern 1/9th of map area (latitude $34.5921^{\circ} \mathrm{N}$., longitude $78.9842^{\circ} \mathrm{W}$.). Surface elevation $104 \mathrm{ft}$.

\section{LITHOLOGY}

DEPTH, IN FEET

\section{Alluvium}

Sand; fine to medium, dominantly fine;

slightly silty; grayish orange (10YR 7/4)

Sand; fine to medium grading down to medium to coarse; coarse fraction subrounded;

soft; yellowish gray (5Y 8/2)

Sand, coarse to very coarse, pebbly

(including common discoids), dark-

gray $(N 3)$; worn shark tooth

\section{Tar Heel Formation}

Sand, very fine to fine, silty, clayey, stiff, dense; pinkish brown (5YR 6/2) grading down through olive gray (5Y 4/1) (9-11 $\mathrm{ft})$ to light olive gray (5Y 6/1)

Sand, very fine to fine, silty, clayey, stiff, dense; yellowish gray (5Y 8/1) grading down to glauconitic and yellowish gray (5Y 6/2) below $18 \mathrm{ft}$; scattered rounded lumps of pyrite up to $1 \mathrm{~cm}$ in diameter at base.

Sand, medium to coarse, subangular to subrounded, micaceous, slightly silty, feldspathic, light-gray $(N 7)$.....

Base of alluvium:

$+97 \mathrm{ft}$ above sea level

\section{Bottomed in Tar Heel Formation}


SL-2-06: $6.42 \mathrm{mi}$ west of eastern quadrangle border, $7.22 \mathrm{mi}$ north of southern quadrangle border, on dirt lane $0.38 \mathrm{mi}$ west-southwest of junction of North Carolina Highway 72 and North Carolina State Road 2115, in northwestern 1/9th of map area (latitude $34.6048^{\circ} \mathrm{N}$., longitude $78.9868^{\circ} \mathrm{W}$.). Surface elevation $143 \mathrm{ft}$.

\section{LITHOLOGY}

DEPTH, IN FEET

\section{Varina Grove unit}

Sand, very fine to fine, silty; yellowish gray

(5Y 6/2) with light-olive-gray (5Y 5/2) streaks

grading at base to medium yellow (5Y 7/4).

Sand, very fine to fine, silty, grayish-orange

(10YR 7/4)

Sand, very fine to fine, silty, clayey, stiff, dark-

yellowish-orange $(10 Y R$ 6/6)

Sand, very fine to fine, silty; yellowish gray

(5Y 8/1) with dark-yellowish-orange

(10YR 6/6) mottles

Sand, very fine to fine, silty; yellowish gray

(5Y 8/1) with light-olive-gray (5Y 6/1)

and dark-yellowish-orange (10YR 6/6) mottles

Silt, clayey, sandy (very fine), micaceous; medium light gray $(N 6)$ grading down through

light brown (5YR 5/6) to bright orange

(10YR 6/8)

Sand, very fine, very silty, slightly clayey;

light brown (5YR 5/6) grading down to

medium gray $(N 5)$

\section{UNCONFORMITY}

\section{Duplin Formation}

Sand, very fine, very silty, slightly clayey, light-yellowish-brown (10YR 6/4); sparse shells (including Mulinia) and shell fragments

Sand; very fine to fine grading down to fine; silty; light olive gray $(5 Y 5 / 2)$; shells increasingly abundant downward

(Dinocardium, oysters, and others) 


\section{Tar Heel Formation}

Sand; very fine to fine, dominantly fine;

clayey; silty; stiff; sticky; micaceous;

glauconitic near base; light olive gray

(5Y 6/1)

UNCONFORMITY

Sand, medium to coarse, feldspathic, variably silty and clayey, dense,

light-brownish-gray (5YR 6/1)

Base of Varina Grove unit:

Base of Duplin Formation:
$+129 \mathrm{ft}$ above sea level

$+107 \mathrm{ft}$ above sea level

\section{Bottomed in Tar Heel Formation}


SL-3-06: $5.63 \mathrm{mi}$ west of eastern quadrangle border, $0.95 \mathrm{mi}$ north of southern quadrangle border, $0.06 \mathrm{mi}$ northnorthwest of unnumbered North Carolina State road, $0.22 \mathrm{mi}$ west of $110-\mathrm{ft}$ spot elevation at T-junction of unnumbered North Carolina State roads, in southwestern $1 / 9$ th of map area (latitude $34.5139^{\circ}$ N., longitude $78.9731^{\circ} \mathrm{W}$.). Surface elevation $108 \mathrm{ft}$.

\section{LITHOLOGY}

DEPTH, IN FEET

\section{Waccamaw Formation, Bahramsville unit}

Sand; very fine to medium, dominantly very fine to fine;

poorly sorted; clayey; dusky brown (5YR 2/2)

grading down to light yellowish gray (5Y 6/2)

with dark-yellowish-orange (10YR 6/6) mottles at $0.5 \mathrm{ft}$

Sand; very fine to fine grading down to very fine to medium; poorly sorted; silty; clayey; light brownish gray $(5 Y R 6 / 1)$

Sand; fine to medium grading down to medium to coarse; silty; light greenish gray (5G 8/1)

Sand, medium to coarse, silty; very pale yellowish brown (10YR 6/2) grading down through dark gray $(N 3)$

(12-15 ft) to bright orange (10YR 6/8); abrupt

basal contact

\section{Tar Heel Formation}

Silt, very clayey, sandy (very fine), dense, stiff; medium gray $(N 5)$ with greenish-gray $(5 G Y 6 / 1)$ mottles grading down to light olive gray (5Y 6/1) at $20 \mathrm{ft}$

\section{Base of Waccamaw Formation, Bahramsville unit:}

$+90 \mathrm{ft}$ above sea level

\section{Bottomed in Tar Heel Formation}


SL-4-06: $3.23 \mathrm{mi}$ west of eastern quadrangle border, $5.76 \mathrm{mi}$ north of southern quadrangle border, $100 \mathrm{ft}$ eastnortheast of house, $0.31 \mathrm{mi}$ southwest of junction of North Carolina Road 1002 with North Carolina Highway 211, 50 $\mathrm{ft}$ north of border between central 1/9th and north central 1/9th of map area (latitude $34.5838^{\circ} \mathrm{N}$., longitude $78.9314^{\circ} \mathrm{W}$.). Surface elevation $122 \mathrm{ft}$.

\section{LITHOLOGY}

DEPTH, IN FEET

\section{Waccamaw Formation, Moorings unit}

Sand, fine to medium, silty, humic, duskybrown $(5 Y R 2 / 2)$.

Sand; fine to medium with scattered

grains up to granule size; subangular to subrounded; slightly silty; slightly thixotropic;

grayish orange pink (5YR 7/2)

Sand, fine, well-sorted, thixotropic, slightly

silty; yellowish brown (10YR 4/4) grading

to pale grayish orange $(10 Y R \mathrm{R} / 4)$ at $7 \mathrm{ft}$.

Sand, fine, well-sorted, thixotropic, silty, soft, pale-yellowish-gray (5Y 8/2)...

\section{Waccamaw Formation, Bahramsville unit}

Silt, very clayey, very pale orange

(10YR 8/2); 3 in. thick

Sand, very fine to fine, silty, slightly clayey; light yellowish brown (10YR 6/4) grading down through olive gray ( $5 Y$ 5/1) (16-18 ft) to humic medium dark gray $(N 4)$

\section{UNCONFORMITY}

\section{Duplin Formation}

Sand, fine to medium, silty, dark-olive-gray

(5Y 3/1); abundant shell fragments and calcite-

cemented nodules enclosing shell

fragments; lower contact gradational

Sand, fine to medium, silty, medium-olive gray (5Y 5/1); about 50 percent of volume composed of shell fragments.

Calcarenite, very fine, very silty; abundant shell fragments; greenish yellow (10Y 6/4);

lower contact gradational

Calcarenite, silty; abundant fine to medium quartz sand and shell fragments, greenish yellow (10Y 6/4) 


\section{Tar Heel Formation}

Sand, medium to coarse, granular,

feldspathic, sparsely micaceous,

slightly silty; tough and dense, but

porous; greenish gray (5GY 6/1).

$47-51$

Base of Waccamaw Formation, Moorings unit:

Base of Waccamaw Formation, Bahramsville unit:

Base of Duplin Formation:
$+107 \mathrm{ft}$ above sea level $+98 \mathrm{ft}$ above sea level

$+75 \mathrm{ft}$ above sea level

Bottomed in Tar Heel Formation 
SL-5-06: $1.40 \mathrm{mi}$ west of eastern quadrangle border, $1.47 \mathrm{mi}$ north of southern quadrangle border, along driveway to abandoned house, $50 \mathrm{ft}$ east of North Carolina State Road 2121, $0.66 \mathrm{mi}$ northeast of junction of North Carolina State Roads 2116 and 2121 (at 94-ft spot elevation), in southeastern 1/9th of map area (latitude $34.5214^{\circ} \mathrm{N}$., longitude $78.8992^{\circ} \mathrm{W}$.). Surface elevation $94 \mathrm{ft}$.

\section{LITHOLOGY}

DEPTH, IN FEET

\section{Windsor Formation}

Sand; fine to medium with scattered subrounded grains up to granule size; silty; humic; dusky brown (5YR 2/2) grading down to dark yellowish brown (10YR 4/2)

Sand, medium to very coarse, poorly sorted, slightly silty, soft; light yellowish brown (10YR 6/4) grading down to pinkish gray (5YR 7/1); subangular to subrounded quartz granules and pebbles up to $1 \mathrm{~cm}$ in diameter

Sand, very fine to fine, silty, clayey, dense, medium-brownish-gray (5YR 5/1)...

Sand, medium to coarse, subangular, slightly

silty, soft, light-grayish-orange-pink (5YR 8/2);

lower contact somewhat gradational

Sand, coarse to very coarse, feldspathic, soft, pale-yellowish-brown (10YR 6/2);

abundant subangular to subrounded quartz granules and pebbles up to $1 \mathrm{~cm}$ in diameter

Sand; medium to coarse grading down to coarse to very coarse; medium brownish gray ( $5 Y R$ 5/1)

Sand, medium to very coarse, poorly sorted, medium-brownish-gray ( $5 Y R 5 / 1)$; subangular to subrounded quartz granules and pebbles up to

$2 \mathrm{~cm}$ in diameter and abundant fragments and wood chips

\section{UNCONFORMITY}

\section{Tar Heel Formation}

Silt, very clayey, sandy (very fine), dense, stiff, medium-olive-gray (5Y 5/1).

Base of Windsor Formation:

$+68 \mathrm{ft}$ above sea level

\section{Bottomed in Tar Heel Formation}


SL-6-06: $1.47 \mathrm{mi}$ west of eastern quadrangle border, $7.72 \mathrm{mi}$ north of southern quadrangle border, on eastern rim of bay $400 \mathrm{ft}$ northeast of pipeline and $0.10 \mathrm{mi}$ northwest of intersection of pipeline and North Carolina State Road 2106, in northeastern $1 / 9$ th of map area (latitude $34.6124^{\circ} \mathrm{N}$., longitude $78.9005^{\circ} \mathrm{W}$.). Surface elevation $144 \mathrm{ft}$.

\section{LITHOLOGY}

DEPTH, IN FEET

\section{Waccamaw Formation, Moorings unit}

Sand, fine, well-sorted, clean; dusky yellowish brown (10YR 2/2) grading down through dark yellowish gray $(5 Y$ 6/2) $(0.5-2 \mathrm{ft})$ and yellowish orange (10YR 7/6) (3-4 ft)

to grayish orange pink (5YR 6/2)

Sand, fine, well-sorted, thixotropic, very dark yellowish orange (10YR 4/6); lower contact gradational

Sand, fine, well-sorted, thixotropic, very humic, dusky-brown (5 YR 2/4)

\section{Waccamaw Formation, Bahramsville unit}

Silt, very clayey, sandy (very fine), soft, greasy;

oily luster; medium gray $(N 4.5)$ grading down through medium dark gray $(N 4)$ to medium greenish gray (5GY 5/1)

\section{UNCONFORMITY}

\section{Duplin Formation}

Sand, fine; medium greenish gray ( $5 G Y 5 / 1)$

grading down to greenish gray $(5 G Y 6 / 1)$ at $37 \mathrm{ft}$;

abundant shell hash; lower contact gradational

Calcarenite, fine, very silty, pale-olive (10Y 7/2);

abundant very fine to fine quartz sand;

lower contact gradational

Calcarenite, fine to medium, silty, quartzose;

black rounded phosphate pebbles up

to $1 \mathrm{~cm}$ in diameter 


\section{Tar Heel Formation}

Sand, fine to medium, very silty and clayey,

stiff, dense, medium-brownish-gray (5YR 5/1);

upper foot contains burrows filled with

overlying lithology.

$42-46$

Base of Waccamaw Formation, Moorings unit:

Base of Waccamaw Formation, Bahramsville unit:

Base of Duplin Formation:

$+126 \mathrm{ft}$ above sea level

$+109 \mathrm{ft}$ above sea level

$+102 \mathrm{ft}$ above sea level

\section{Bottomed in Tar Heel Formation}


SL-7-06: $4.88 \mathrm{mi}$ west of eastern quadrangle border, $5.81 \mathrm{mi}$ north of southern quadrangle border, on southern side of unnumbered dirt road running west from North Carolina State Road 2116, on northeastern rim of unnamed bay $100 \mathrm{ft}$ east of power line, in northwestern $1 / 9$ th of map area (latitude $34.5846^{\circ} \mathrm{N}$., longitude $78.9603^{\circ} \mathrm{W}$.). Surface elevation $138 \mathrm{ft}$.

\section{LITHOLOGY}

DEPTH, IN FEET

\section{Waccamaw Formation, Moorings unit}

Sand, fine, silty, slightly clayey; yellowish brown (10YR 5/2) grading down through pale grayish orange (10YR 8/4) to dark yellowish orange (10YR 6/6)

Sand, fine, silty, clayey; yellowish orange (10YR 7/6) with increasingly abundant yellowish-gray (5Y 7/2) mottles downward, and pale reddish brown (10R 5/6)

Sand, fine, well-sorted, soft, thixotropic; pale reddish brown $(10 R 5 / 6)$ grading down through pale yellowish gray (5Y 8/2) (7-9 $\mathrm{ft})$ to pale brownish gray $(5 Y R \quad 7 / 1)$.

Sand, fine, well-sorted, soft, thixotropic; medium brown (5YR 4/4) grading down through dark grayish red (5R 3/2) (18-19ft) to pale grayish red ( $5 R 5 / 2)$

Sand, very fine to fine, clayey, silty; very pale orange (10YR 8/2) grading down to yellowish gray (5Y 8/1)

\section{Waccamaw Formation, Bahramsville unit}

Silt, clayey; medium reddish brown (10R 4/6)

with yellowish orange (10YR 5/6) streaks grading rapidly down to olive gray (5Y 4/1) at $23.5 \mathrm{ft}$; very fine to fine (sandy) in upper foot; greasy texture below $24 \mathrm{ft}$; wood chips in basal foot

\section{UNCONFORMITY}

\section{Duplin Formation}

Sand, very fine to medium, poorly sorted, silty, yellowish-brown (10YR 5/2); sparse rounded, coarse grains.

Base of Waccamaw Formation, Moorings unit: Base of Waccamaw Formation, Bahramsville unit:

\section{Bottomed in Duplin Formation}


SL-8-06: $4.75 \mathrm{mi}$ west of eastern quadrangle border, $4.40 \mathrm{mi}$ north of southern quadrangle border, on western side of North Carolina State Road 2116, 0.23 mi north of the "o" in "Horse Bluff Landing” label on map, $50 \mathrm{ft}$ east of the border between the central and west-central $1 / 9$ th of map area (latitude $34.5640^{\circ} \mathrm{N}$., longitude $78.9577^{\circ} \mathrm{W}$.). Surface elevation $103 \mathrm{ft}$.

\section{LITHOLOGY}

DEPTH, IN FEET

\section{Waccamaw Formation, Bahramsville unit}

Sand, fine, silty, clayey, stiff; dusky yellowish brown (10YR 2/2) grading down through medium yellowish brown (10YR 5/4) and yellowish orange (10YR 7/6)

to light yellowish brown (10YR 6/4) with dark-orange (10YR 8/6) mottles .....

Sand, fine, silty, clayey, pale-yellowish-

brown (10YR 6/2)

Sand, fine to medium, clean; grayish orange pink (5YR 6/2) grading down to pale brown $(5 Y R 5 / 2)$ at $5 \mathrm{ft}$.

Sand, fine to medium, angular to subangular, silty, humic, dark-grayish-red (10R 3/2); lower contact gradational

Sand, medium to very coarse, angular to subangular, silty, humic, very dark reddish brown $(10 R 2 / 4)$

Gravel; subrounded to rounded quartz pebbles up to $1 \mathrm{~cm}$ in diameter; medium to coarse quartz-sand matrix; very dark reddish brown $(10 R 2 / 4)$

\section{UNCONFORMITY}

\section{Duplin Formation}

Sand, fine, well-sorted, silty, kaolinitic, micaceous, pale-yellowish-gray (5Y 8/2) 


\section{Tar Heel Formation}

Sand, fine to coarse, poorly sorted, silty, clayey,

micaceous, dense, stiff, medium-gray ( $N 5)$;

scattered subrounded quartz granules

Base of Waccamaw Formation, Bahramsville unit: Base of Duplin Formation:

$+81 \mathrm{ft}$ above sea level $+79 \mathrm{ft}$ above sea level

\section{Bottomed in Tar Heel Formation}


SL-9-06: $4.49 \mathrm{mi}$ west of eastern quadrangle border, $0.40 \mathrm{mi}$ north of southern quadrangle border, $50 \mathrm{ft}$ west of western side of North Carolina Highway 72, at junction with North Carolina State Road 2121, in south-central 1/9th of map area (latitude $34.5060^{\circ} \mathrm{N}$., longitude $78.9531^{\circ} \mathrm{W}$.). Surface elevation $119 \mathrm{ft}$.

\section{LITHOLOGY}

DEPTH, IN FEET

\section{Waccamaw Formation, Moorings unit}

Sand, very fine to fine; dusky yellowish brown

(10YR 3/2) grading down to dusky yellowish

brown $(10 Y R$ 2/2).......

Sand, very fine to fine; abundant very

fine, dark, heavy mineral grains; clean; yellowish

orange (10YR 7/6) grading down through

grayish yellow (5Y 7/4) (2-4 ft) to light

pinkish gray (5YR 9/1)

\section{Waccamaw Formation, Bahramsville unit}

Silt, very clayey, sandy (very fine), sticky, greasy;

dark brownish black (5YR 3/1) grading down through

light olive gray (5Y 6/1) (7-7.5 ft) and

yellowish orange $(10 Y R$ 7/6) $(7.5-9 \mathrm{ft})$

to medium grayish brown (5YR 4/2)

Silt, clayey, sandy (very fine), light-olive-gray

(5Y 6/1)

Sand, fine to coarse, subangular to angular, very

silty; black wood chips in basal foot;

bluish gray (5B 6/1)

\section{UNCONFORMITY}

\section{Tar Heel Formation}

Silt, clayey, sandy (very fine), very stiff, very

dense, dark greenish gray (5G 4/1) with

medium-gray $(N 5)$ streaks

Base of Waccamaw Formation, Moorings unit:

Base of Waccamaw Formation, Bahramsville unit:
$+113 \mathrm{ft}$ above sea level

$+84 \mathrm{ft}$ above sea level

\section{Bottomed in Tar Heel Formation}




\section{Tar Heel Quadrangle}

TH-1-06: $0.59 \mathrm{mi}$ west of eastern quadrangle border, $0.83 \mathrm{mi}$ north of southern quadrangle border, on southwestern side of ditch, $0.10 \mathrm{mi}$ west of North Carolina Highway 131, $0.11 \mathrm{mi}$ southwest of junction of North Carolina Highway 131 and North Carolina State Road 1103 at 133-ft spot elevation, in southeastern 1/9th of map area (latitude $34.6371^{\circ} \mathrm{N}$., longitude $78.7598^{\circ} \mathrm{W}$.). Surface elevation $133 \mathrm{ft}$.

\section{LITHOLOGY}

DEPTH, IN FEET

\section{Waccamaw Formation, Moorings unit}

Sand, very fine to fine, silty, slightly clayey; medium olive brown (5Y 4/6) grading down to light yellowish brown (10YR 6/4)

Sand, very fine to fine, silty, clayey, light-olive-

brown (5Y 5/4); lower contact gradational.

Sand, very fine to fine, silty; medium yellowish orange $(10 Y R 5 / 6)$ grading down to yellowish orange (10YR 7/6) with yellowish-gray (5Y 7/1) mottles.

Sand, very fine to fine, silty; very light gray $(N 8)$ grading to bright reddish brown (10R 5/9) at $8 \mathrm{ft}$.

Sand, very fine to fine, clean, thixotropic; bright orange (10YR 5/8) grading down to pale yellowish gray ( $5 Y$ 8/2) at $12 \mathrm{ft}$; $1-2$ percent very fine, dark, heavy mineral grains.

\section{Waccamaw Formation, Bahramsville unit}

Silt, clayey, sandy (very fine), greasy; very light gray $(N 8)$ grading down through pale orange $(10 Y R$ 8/8)

$(18.5-19 \mathrm{ft})$ and medium greenish gray $(5 G 5 / 1)$

$(19.5-25 \mathrm{ft})$ to greenish gray (5GY 6/1)

Sand; fine to medium grading down to medium to coarse; greenish gray $(5 G Y 6 / 1)$ grading down to dark bluish gray $(5 B 3 / 1)$; bone fragment on basal contact. 


\section{Duplin Formation}

Sand, very fine to fine, silty, clayey, finely

micaceous, dense, dark-greenish-gray

(5G 4/1); shell fragments and

calcified burrow fillings*

Base of Waccamaw Formation, Moorings unit:

Base of Waccamaw Formation, Bahramsville unit:

$+115 \mathrm{ft}$ above sea level

$+100 \mathrm{ft}$ above sea level

\section{Bottomed in Duplin Formation}

*Sample from this interval contained fragments of marine dinoflagellates and one whole specimen of Lingulodinium machaerophoram (Paleocene to modern) (Lucy E. Edwards, USGS, oral commun., 2006). 
TH-2-06: $1.08 \mathrm{mi}$ west of eastern quadrangle border, $6.76 \mathrm{mi}$ north of southern quadrangle border, on eastern side of unnumbered dirt road that runs south-southwest from North Carolina Highway 87, 0.27 mi southeast of 155-ft Wengert benchmark, in northeastern 1/9th of map area (latitude $34.7234^{\circ} \mathrm{N}$., longitude $78.7686^{\circ} \mathrm{W}$.). Surface elevation $152 \mathrm{ft}$.

\section{LITHOLOGY}

DEPTH, IN FEET

\section{Waccamaw Formation, Moorings unit}

Sand; very fine to fine, dominantly fine; increasingly silty and clayey downward; finely micaceous; dark yellowish brown (10YR 4/2) grading down through light yellowish brown $(10 Y R$ 6/4) to dark yellowish orange (10YR 6/6).

Sand, very fine to medium, poorly sorted, silty; light yellowish brown (10YR 6/4) grading down through yellowish gray (5Y 8/1) (3-5 ft) and yellowish gray (5Y 7/2) (5-11 ft) to pale yellowish brown (10YR 6/2); lower contact gradational

Sand, very fine to medium, poorly sorted, silty, thixotropic; light brown (10YR 5/4) grading down through reddish brown $(10 R 4 / 4)$

(14-15 ft), dusky reddish brown (10R 2/4)

(15-17 ft), brown (5YR 5/4) (17-18 ft), and orange pink (5YR 7/4) (18-20 ft) to yellowish orange (10YR 7/6) with yellowish gray (5Y 8/1) streaks

Sand, very fine to fine, slightly silty, yellowish-gray (5Y 8/1); 1-2 percent very fine, dark, heavy mineral grains

\section{Waccamaw Formation, Bahramsville unit}

Silt, clayey, sandy (very fine); pinkish gray (5YR 8/1) grading down through dark yellowish orange $(10 Y R$ 6/6) to greenish gray $(5 G Y$ 6/1)

Sand, very fine to medium, poorly sorted, subangular to angular, silty, clayey, darkbluish-gray (5B 4/1)

Silt, clayey, sandy (very fine), dark-bluishgray $(5 B 4 / 1)$.

Sand; fine to medium grading down to medium to very coarse; poorly sorted; dark bluish gray (5B 4/1); subrounded quartz granules.... 


\section{Tar Heel Formation}

Sand, fine to medium; light olive gray

(5Y 6/1) grading down through medium

brownish gray (5YR 5/1) and

medium gray $(N 6)$ to light olive gray

(5Y 6/1); lower contact abrupt.

Silt, very clayey, sandy (very fine),

dense, stiff, olive-gray (5Y 4/1)

Base of Waccamaw Formation, Moorings unit:

Base of Waccamaw Formation, Bahramsville unit:

$+128 \mathrm{ft}$ above sea level

$+112 \mathrm{ft}$ above sea level

\section{Bottomed in Tar Heel Formation}


TH-3-06: $6.13 \mathrm{mi}$ west of eastern quadrangle border, $6.37 \mathrm{mi}$ north of southern quadrangle border, on northeastern side of North Carolina State Road 1969, 0.43 mi northwest of bridge over Lewis Mill Branch, in northwestern 1/9th of map area (latitude $34.7174^{\circ} \mathrm{N}$., longitude $78.8574^{\circ} \mathrm{W}$.). Surface elevation $131 \mathrm{ft}$.

\section{LITHOLOGY}

DEPTH, IN FEET

\section{Varina Grove unit}

Sand, very fine, well-sorted, clean, grayishorange $(10 Y R 7 / 4)$.

Sand, very fine, silty, slightly clayey, dark-

yellowish-orange (10YR 6/6)

Sand, very fine, clayey, silty, very stiff, dense;

very light olive gray (5Y 7/1) with medium-reddish-

brown (10R 4/6) mottles below $4 \mathrm{ft}$

Sand, fine to medium, silty, bright-yellowishorange (10YR 6/8); lower contact gradational.

Sand; medium to coarse grading down to

fine to coarse with scattered angular, very

coarse grains; poorly sorted; silty; yellowish

orange (10YR 8/7) grading down through pale

yellowish orange (10YR 8/4) (19-21 ft),

very pale orange $(10 Y R \mathrm{R} / 2)(21-23 \mathrm{ft})$,

and yellowish gray $(5 Y$ 8/1) (23-23.5 ft)

to pinkish gray (5YR 8/1)

Sand, fine to very coarse, very poorly sorted;

very coarse fraction subrounded to rounded; silty,

slightly clayey; dark gray $(N 3)$ grading down

through black $(N 1)(26-27 \mathrm{ft})$ and

medium dark gray $(N 4)(27-29 \mathrm{ft})$

to medium gray $(N 5)$.

Silt, clayey, sandy (very fine), stiff, finely

micaceous, carbonaceous, medium-

bluish-gray (5B 5/1)

Sand; fine to medium grading down to very

fine to fine; silty; micaceous; dark gray $(N 3)$

grading down to medium light gray $(N 6)$

at $33 \mathrm{ft}$; lower contact gradational.

Sand, fine to medium, silty, medium-light-

gray $(N 6)$ 


\section{Tar Heel Formation}

Silt, very clayey, sandy (very fine), stiff,

dense; medium dark bluish gray (5B 4/1)

grading down to dark gray $(N 3)$;

abundant fine, silvery mica and brown to

black lignite containing numerous pyrite

crystals

$42-47$

Sand, very fine to fine, silty, very micaceous;

medium gray $(N 5)$ grading down to medium

bluish gray (5B 6/1)

$47-51$

Base of Varina Grove unit:

$+89 \mathrm{ft}$ above sea level

\section{Bottomed in Tar Heel Formation}


TH-4-06: $4.74 \mathrm{mi}$ west of eastern quadrangle border, $3.77 \mathrm{mi}$ north of southern quadrangle border, at entrance to unnumbered dirt road running from eastern side of loop in North Carolina State Road 1967, $20 \mathrm{ft}$ east of 134-ft spot elevation, $50 \mathrm{ft}$ east of border between west-central and central 1/9th of map area (latitude $34.6797^{\circ} \mathrm{N}$., longitude $78.8330^{\circ} \mathrm{W}$.). Surface elevation $133 \mathrm{ft}$.

\section{LITHOLOGY}

DEPTH, IN FEET

\section{Varina Grove unit}

Sand; very fine to fine, dominantly very fine;

slightly silty; dusky yellow (5Y 6/4) grading down

through dark yellowish orange (10YR 6/6)

(1-2 ft) to yellowish orange (10YR 7/6)

with pale-greenish-yellow (10Y 8/2) mottles

Sand; very fine to fine, dominantly very fine;

slightly silty; yellowish gray ( $5 Y$ 8/1) grading down

through grayish orange (10YR 7/2) (7-9

$\mathrm{ft}$ ) and grayish yellow (5Y 7/4) (9-11 ft) to

brownish gray (5YR 4/1) .

Sand, very fine to fine, silty, clayey, stiff,

yellowish-gray $(5 Y 7 / 2)$...

Sand, very fine to fine, silty, soft, yellowish-

brown (10YR 5/2); lower contact somewhat gradational

Sand, medium to coarse, silty; bright

yellowish orange (10YR 7/8) grading

down to yellowish orange (10YR 6/8);

lower contact gradational....

Sand, medium to very coarse, poorly sorted,

silty, grayish-orange (10YR 7/4)

\section{Duplin Formation}

Silt, clayey, sandy (very fine), mediumyellow $(5 Y 7 / 6)$.

Sand, fine to medium, silty, dark-yellowishorange (10YR 6/8) . 


\section{Tar Heel Formation}

Silt, very clayey, sandy (very fine), finely

micaceous, carbonaceous, stiff, dense;

pale yellowish brown (10YR 6/2) grading

rapidly down to brownish gray (5YR $5 / 1)$;

lumps of pyrite up to $1 \mathrm{~cm}$ in diameter;

grades down to very fine, silty, very micaceous,

medium-gray $(N 5)$ sand

Base of Varina Grove unit:

Base of Duplin Formation:

$+105 \mathrm{ft}$ above sea level

$+100 \mathrm{ft}$ above sea level

\section{Bottomed in Tar Heel Formation}


TH-5-06: $5.69 \mathrm{mi}$ west of eastern quadrangle border, $0.66 \mathrm{mi}$ north of southern quadrangle border, on southern side of unnumbered dirt road running southeastward from North Carolina State Road 2100 at 115-ft spot elevation, $0.10 \mathrm{mi}$ east of cemetery, in southwestern $1 / 9$ th of map area (latitude $34.6362^{\circ} \mathrm{N}$., longitude $78.8492^{\circ} \mathrm{W}$.). Surface elevation $107 \mathrm{ft}$.

\section{LITHOLOGY}

DEPTH, IN FEET

\section{Windsor Formation}

Sand; very fine to coarse, dominantly fine; poorly sorted; coarse fraction subrounded; silty; medium yellowish brown (10YR 5/6)

Sand; fine to medium grading down to medium to coarse; silty; yellowish orange (10YR 7/6)

grading down to medium brown (10YR 5/2).

\section{UNCONFORMITY}

\section{Varina Grove unit}

Silt, clayey, sandy (very fine), stiff; dark yellowish orange (10YR 6/6) grading down through pale reddish brown (10R 5/4) with yellowish-gray (5Y 7/2) streaks (6.25-8 ft), yellowish orange (10YR 7/6) (8-8.5 ft), and light olive gray (5Y 6/1) (8.5-13 ft) to olive gray (5Y 5/1) with pale-yellowish-brown (10YR 6/2) streaks...

Sand, fine to medium, silty; dark yellowish orange (10YR 6/6) grading down to light yellowish brown (10YR 6/4) at $15 \mathrm{ft}$

Silt, sandy (very fine), clayey, paleyellowish-brown (10YR 6/2).....

Sand; fine to medium grading down to medium to very coarse; poorly sorted; subangular; subrounded quartz granules near base; silty; light yellowish brown (10YR 6/4) 


\section{Tar Heel Formation}

Sand, fine to coarse, poorly sorted,

feldspathic, micaceous, silty, kaolinitic,

dense; scattered subangular,

very coarse to granule-sized grains of

quartz; very pale orange (10YR 8/2).

$24-26$

Base of Windsor Formation:

Base of Varina Grove unit:

$+101 \mathrm{ft}$ above sea level

$+83 \mathrm{ft}$ above sea level

\section{Bottomed in Tar Heel Formation}


TH-6-06: $3.30 \mathrm{mi}$ west of eastern quadrangle border, $2.32 \mathrm{mi}$ north of southern quadrangle border, on southern side of unnumbered dirt road about $0.05 \mathrm{mi}$ south of Allen Pocket Canal, $0.11 \mathrm{mi}$ west-northwest of junction of the canal with North Carolina State Road 1101, in south-central 1/9th of map area (latitude $34.6588^{\circ} \mathrm{N}$., longitude $78.8076^{\circ} \mathrm{W}$.). Surface elevation $121 \mathrm{ft}$.

\section{LITHOLOGY}

DEPTH, IN FEET

\section{Waccamaw Formation, Bahramsville unit}

Sand, fine to medium, angular to subangular; grayish orange (10YR 7/4) grading down through yellowish orange (10YR 7/6) (1-3 ft) and pale greenish yellow (10Y 8/4)

(3-5 ft) to pale yellowish gray (5Y 9/1)

Sand; fine to medium grading down to fine to coarse; silty; light yellowish brown (10YR 6/4) grading down through grayish orange (10YR $7 / 4)$ (7.33-9 ft) and light orange (10YR 7/8) (9-10 ft) to bright orange (10YR 6/8)

Sand, fine to coarse, subangular, silty, paleyellowish-brown (10YR 7/2); lower contact somewhat gradational $11-18$

Sand, fine to medium, subangular to subrounded, silty, light-grayish-brown (5YR 4/2); scattered subrounded to rounded coarse grains; lower contact gradational

Sand; fine grading down to fine to medium; angular to subangular; silty; light olive gray (5Y 6/1); lower contact gradational.

Sand, medium to coarse, dark-olive-gray (5Y 3/1)

\section{UNCONFORMITY}

\section{Tar Heel Formation}

Sand; fine to medium grading down to medium to very coarse; poorly sorted; subrounded to rounded; silty; clayey; kaolinitic; micaceous; dense; bluish gray (5B 6/1); wood fragment at base.

Silt, clayey, sandy (very fine), dense; medium gray $(N 5)$ grading down to medium bluish gray (5B 5/1) at $31 \mathrm{ft}$

Sand, very fine to fine, silty, slightly clayey, coarsely micaceous, medium bluish gray ( $5 B$ 5/1)

\section{Bottomed in Tar Heel Formation}


TH-7-06: $0.41 \mathrm{mi}$ west of eastern quadrangle border, $3.10 \mathrm{mi}$ north of southern quadrangle border, $0.05 \mathrm{mi}$ northnorthwest of Allen Cemetery and $100 \mathrm{ft}$ east of rim of unnamed Carolina bay, in east-central 1/9th of map area (latitude $34.6702^{\circ} \mathrm{N}$., longitude $78.7567^{\circ} \mathrm{W}$.). Surface elevation $141 \mathrm{ft}$.

\section{LITHOLOGY}

DEPTH, IN FEET

\section{Waccamaw Formation, Moorings unit}

Sand, very fine to fine, silty; grayish yellow

(5Y 7/4) grading down through very dark yellowish orange $(10 Y R 5 / 6)(0.5-1 \mathrm{ft})$, dark yellowish orange (10YR 6/6) (1-4 ft), and grayish yellow (5Y 7/4) (4-6 ft) to

light brown (5YR 5/4)...

Sand, very fine to fine, very silty, soft, lightorange $(10 Y R 7 / 8)$

\section{Waccamaw Formation, Bahramsville unit}

Silt, clayey, sandy (very fine); medium reddish orange (10R 6/6) grading down to medium orange pink (10R 7/4)

Sand, very fine to fine, dominantly fine, very silty, medium-orange-pink (10R 7/4).

Silt, clayey, yellowish-gray (5Y 8/1); 1

in. thick

Sand, very fine, silty, light-orange (10YR 7/8);

lower contact gradational

Sand, very fine to fine, silty, pinkish-gray

(5YR 8/1); lower contact gradational.

Sand, fine to medium, slightly silty; yellowish gray (5Y 8/1) grading down through light brown (5YR 5/6) (29-30 ft) to yellowish orange (10YR 5/6)

Sand; fine to medium grading down to fine to very coarse; very poorly sorted; silty; very pale orange (10YR 8/2); lower contact gradational.....

Sand; fine to very coarse grading down to medium to very coarse; poorly sorted; subangular to subrounded; silty; yellowish gray (5Y 8/1); subrounded quartz granules and small pebbles 


\section{Tar Heel Formation}

Sand, very fine to fine, silty, clayey,

micaceous, dense; yellowish gray

(5Y 8/1) grading down through bright orange

(10YR 6/8) (48-49 ft) to pale brown

(5YR 6/6) with pale-orange (10YR 8/8) streaks

$47-51$

Base of Waccamaw Formation, Moorings unit:

Base of Waccamaw Formation, Bahramsville unit:

$+124 \mathrm{ft}$ above sea level

+94 ft above sea level

\section{Bottomed in Tar Heel Formation}


TH-8-06: $3.86 \mathrm{mi}$ west of eastern quadrangle border, $6.90 \mathrm{mi}$ north of southern quadrangle border, along northwestern border of field $0.07 \mathrm{mi}$ northeast of North Carolina State Road 1300, $0.39 \mathrm{mi}$ northwest of junction of North Carolina State Roads 1300 and 1004 (at 134-ft spot elevation), in north-central 1/9th of map area (latitude $34.7252^{\circ} \mathrm{N}$., longitude $78.8177^{\circ} \mathrm{W}$.). Surface elevation $133 \mathrm{ft}$.

\section{LITHOLOGY}

DEPTH, IN FEET

\section{Waccamaw Formation, Bahramsville unit}

Sand, fine to medium, silty, light-olivebrown $(5 Y 6 / 6)$......

Sand; fine to medium grading down to very fine to fine; silty; yellowish gray $(5 Y 8 / 1)$

Silt, clayey, sandy (very fine), stiff, yellowish-gray $(5 Y 8 / 1)$.

Sand, very fine to fine, slightly silty; yellowish gray (5Y 8/1) grading down through yellowish gray $(5 Y 7 / 1)$ back to yellowish gray $(5 Y 8 / 1)$

Sand; fine to medium grading down through medium and coarse (16-19 $\mathrm{ft}$ ) to medium to very coarse; poorly sorted; clean; angular to subangular; yellowish gray ( $5 Y$ 8/1) grading down to pale orange (10YR 8/8) at $21 \mathrm{ft}$

\section{Tar Heel Formation}

Sand, fine to medium, silty, slightly

clayey, dense; pale orange

(10YR 7/2) grading down to

grayish orange (10YR 7/4)...

Silt, clayey, sandy (very fine);

increasingly micaceous downward;

stiff; greasy texture; light olive gray

(5Y 6/1) grading down rapidly at $27.5 \mathrm{ft}$

to dark gray $(N 3)$; sparse wood fragments

Sand, very fine to fine, silty, abundantly

micaceous; medium light gray ( $N$ 6)

grading down to light gray $(N 7)$;

fragment of carbonized wood

in basal foot.

Base of Waccamaw Formation, Bahramsville unit:

$+111 \mathrm{ft}$ above sea level

\section{Bottomed in Tar Heel Formation}




\section{Tomahawk Quadrangle}

TO-1-08: $1.75 \mathrm{mi}$ west of eastern quadrangle border, $1.83 \mathrm{mi}$ north of southern quadrangle border, along old railroad bed, 0.30 mi south-southeast of railroad bed crossing with North Carolina State Road 1007 at Kerr, in southeastern $1 / 9$ th of map area (latitude $34.6517^{\circ} \mathrm{N}$., longitude $78.2805^{\circ} \mathrm{W}$.). Surface elevation $77 \mathrm{ft}$.

\section{LITHOLOGY}

DEPTH, IN FEET

Sand, fine to medium, clean, slightly humic, pale-

yellowish-brown (10YR 6/2) (railroad bed fill).

\section{UNCONFORMITY}

\section{Dune sand}

Sand, fine to medium, clean, humic; dusky yellowish brown (10YR 1/2) grading down through dark yellowish brown (10YR 4/2) (2.5-3 ft), light yellowish brown (10YR 6/4) (3-4.5 ft), dark yellowish orange (10YR 6/6) $(4.5-5 \mathrm{ft})$, and pale brown (5YR 6/2) (5-5.5 ft), to very dusky red $(10 R 2 / 2)$......

\section{Charles City Formation}

Sand, fine, silty, humic, dark-yellowish-brown

(10YR 3/2)

Sand, fine, slightly silty; medium yellowish brown $(10 Y R 5 / 4)$ grading down to dusky yellowish orange $(10 Y R 5 / 6)$ at $9 \mathrm{ft}$.

Sand, fine to medium, silty, dusky-yellowishorange (10YR 5/6); lower contact gradational.

Sand, medium to very coarse, granular, poorly sorted, dusky-yellowish-orange (10YR 5/6); coarse to granule fraction subrounded to rounded

Sand; fine to medium grading down to coarse to very coarse with scattered rounded and polished quartz granules; dark yellowish brown 10YR 4/4) grading down to very pale orange $(10 Y R 8 / 2)$ at base

Sand; fine to coarse grading down to medium to very coarse; poorly sorted; silty; yellowish gray (5Y 8/1) grading down to pale yellowish brown (10YR 6/2) at $34 \mathrm{ft}$; locally gravelly with rounded quartz pebbles up to $7 \mathrm{~cm}$ in length; some clayballs in basal $2 \mathrm{ft}$ 


\section{Tar Heel Formation}

Sand, very fine to fine, slightly silty and clayey,

micaceous, dark-olive-gray ( $5 Y 3 / 1)$; thin layers

of dense, greenish-black (5GY 2/1), silty clay

and fine, well-sorted, micaceous dark-greenish-

gray (5GY 4/1), sand with very dusky red (10R $2 / 2)$

lignite fragments

36-41

Base of dune sand:

Base of Charles City Formation:

$+70 \mathrm{ft}$ above sea level

+41 ft above sea level

\section{Bottomed in Tar Heel Formation}


TO-2-08: $5.50 \mathrm{mi}$ west of eastern quadrangle border, $3.07 \mathrm{mi}$ north of southern quadrangle border, on northwestern side of unnumbered dirt road leading southwest from North Carolina Highway 210, $50 \mathrm{ft}$ southwest of North Carolina Highway 210 and 0.34 mi west-northwest of 47-ft spot elevation point along North Carolina Highway 210, in westcentral 1/9th of map area (latitude $34.6695^{\circ} \mathrm{N}$., longitude $78.3461^{\circ} \mathrm{W}$.). Surface elevation $60 \mathrm{ft}$.

\section{LITHOLOGY}

DEPTH, IN FEET

\section{Dune sand}

Sand, fine to medium, clean, slightly humic; medium brown (5YR 4/4) grading down through grayish orange (10YR 7/4) (0.5$1 \mathrm{ft}$ ) and very pale orange (10YR 8/2) (1-4 ft) to dark yellowish orange (10YR 6/6)

\section{UNCONFORMITY}

\section{Chuckatuck Formation}

Sand, fine to medium, very silty, slightly clayey, yellowish-brown (10YR 5/2);

much denser than unit above.

Sand, fine to coarse, angular to subrounded, silty; grades down to medium to very coarse, gravelly with subangular to rounded quartz pebbles up to $2 \mathrm{~cm}$ in length; poorly sorted; yellowish brown (10YR 5/2) grading down through pale grayish orange (10YR 8/4) and very pale orange $(10 Y R \quad 8 / 2)$ to grayish orange (10YR 7/4) 6-15

\section{Tar Heel Formation}

Silt, very clayey, very stiff, dense, duskygreenish-gray (5GY 3/1); carbon streaks near base

Sand, fine to coarse, poorly sorted, angular to subangular, granular, silty, carbonaceous; dark greenish gray (5GY 3/1) with dark-yellowish-brown (10YR 3/2), carbonaceous streaks grading down to dark greenish gray (5GY 4/1); lens of dusky-greenish-gray (5GY 3/2), lignitic clay in basal foot; very dark yellowish brown $(10 Y R$ 3/2) lignite

Base of dune sand:

Base of Chuckatuck Formation:

\section{Bottomed in Tar Heel Formation}


TO-3-08: $3.26 \mathrm{mi}$ west of eastern quadrangle border, $4.85 \mathrm{mi}$ north of southern quadrangle border, at junction of two unnumbered dirt roads where 98-ft spot elevation was taken, $0.28 \mathrm{mi}$ northeast of 99-ft Dismal benchmark along old railroad line, in central $1 / 9$ th of map area (latitude $34.6955^{\circ} \mathrm{N}$., longitude $78.3066^{\circ} \mathrm{W}$.). Surface elevation $98 \mathrm{ft}$.

\section{LITHOLOGY}

DEPTH, IN FEET

\section{Dune sand}

Sand, fine to medium, clean, humic; dusky yellowish

brown $(10 Y R 2 / 2)$ changing abruptly to pale

yellowish brown $(10 Y R$ 6/2) at 4 in

Sand, fine to medium, humic, dusky-yellowish-brown

(10YR 2/2)

Peat with abundant wood fragments, dusky-

yellowish-brown $(10 Y R$ 2/2)*

Sand, fine to medium, silty, humic, dusky-yellowish-

brown (10YR 2/2)

\section{Windsor Formation}

Sand, very fine, silty, tough, dense; medium brown

$(5 Y R 3 / 6)$ grading down to dark grayish yellow (5Y 7/4)

Sand, very fine to fine, silty, soft, light-yellowish-brown

(10YR 6/4)

Sand; medium to very coarse with subrounded quartz

pebbles up to $2 \mathrm{~cm}$ in length; poorly sorted; silty; soft; dark yellowish

brown (10YR 4/4) grading down to dark yellowish

brown (10YR 3/2); lower contact gradational

Sand, fine to medium, silty, soft, dark-yellowish-

brown (10YR 3/2)

Sand; fine to coarse with subrounded quartz pebbles

up to $1 \mathrm{~cm}$ in length; poorly sorted; silty; soft; pale yellowish brown

$(10 Y R 7 / 2)$

Sand; very fine to coarse with abundant quartz granules and pebbles up to $1 \mathrm{~cm}$ in length; very poorly sorted; very clayey

and silty; sticky; pale yellowish gray (5Y 9/1); thin layer

of yellowish-gray (5Y 8/1), very clayey silt at $40 \mathrm{ft}$

\section{Tar Heel Formation}

Sand, very fine to fine, silty, very micaceous, dense, greenish-gray (5GY 5/1) 
Sand, very fine to fine, clayey, silty, dense, sticky,

lignitic, olive-black (5Y 2/1); contains burrows filled

with above lithology

49-49.5

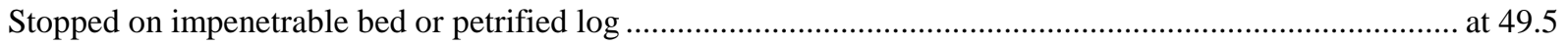

Base of dune sand:

Base of Windsor Formation:

$+92 \mathrm{ft}$ above sea level

+52 ft above sea level

\section{Bottomed in Tar Heel Formation}

*Wood fragment in peat yielded a radiocarbon age greater than 51,800 B.P.

(John P. McGeehin, USGS, written commun., 2008). 
TO-4-08: $0.68 \mathrm{mi}$ west of eastern quadrangle border, $6.37 \mathrm{mi}$ north of southern quadrangle border, $100 \mathrm{ft}$ north of North Carolina Highway 41, $0.55 \mathrm{mi}$ west of 45-ft Billy benchmark, in northeastern 1/9th of map area (latitude $34.7173^{\circ} \mathrm{N}$., longitude $78.2618^{\circ} \mathrm{W}$.). Surface elevation $46 \mathrm{ft}$.

\section{LITHOLOGY}

DEPTH, IN FEET

\section{Alluvium}

Sand, fine, well-sorted, silty, soft; medium yellowish brown (10YR $5 / 4)$ grading down to light yellowish brown (10YR 6/4)

Sand, fine, well-sorted, slightly silty, thixotropic; light yellowish brown (10YR 6/4) grading down through dark yellowish orange (10YR 6.5/6) to pale grayish orange pink (5YR 8/2); contains $<1$ percent very fine, dark, heavy mineral grains; lower contact somewhat gradational

Sand, medium to very coarse, poorly sorted, pale-grayish-orange-pink (5YR 8/2); abundant subrounded to rounded quartz pebbles up to $3 \mathrm{~cm}$ in length in basal foot.

\section{Tar Heel Formation}

Clay, silty, sandy (very fine), micaceous, stiff, dense, dark-olive-gray (5Y 3/1); wood and pyrite lumps; small burrows

filled with clean, very fine sand; thin

lenses of very fine sand in basal foot

Base of alluvium:

$+38 \mathrm{ft}$ above sea level

\section{Bottomed in Tar Heel Formation}


TO-5-08: $1.75 \mathrm{mi}$ west of eastern quadrangle border, $1.83 \mathrm{mi}$ north of southern quadrangle border, $50 \mathrm{ft}$ west of North Carolina State Road 1132 at entrance to unnumbered dirt road leading west-southwest from North Carolina State Road 1132, $200 \mathrm{ft}$ south of $103-\mathrm{ft}$ spot elevation, in northwestern 1/9th of map area (latitude $34.7371^{\circ} \mathrm{N}$., longitude $78.3695^{\circ} \mathrm{W}$.). Surface elevation $103 \mathrm{ft}$.

\section{LITHOLOGY}

DEPTH, IN FEET

\section{Dune sand}

Sand, fine to medium, slightly silty, humic, lightgrayish-brown $(10 Y R$ 4/2).

Sand, fine to medium, clean, soft, dark-yellowish-

orange (10YR 6.5/6)

Sand, fine to medium, slightly silty; dark yellowish orange (10YR 6.5/6) grading down through dark yellowish orange (10YR 6/6), light yellowish brown (10YR 6/4), and dark yellowish brown (10YR 4/2) to grayish orange pink (5YR 7/2)

Sand, fine to medium, slightly silty, humic; brownish black (10YR 1/2) grading down to dark reddish brown (5YR 3/4) .

Sand; fine to medium, dominantly medium; pale brown (10YR 6/2) grading down to very humic and dusky yellowish brown (10YR 2/2)

Sand, very fine, silty, massive (loess?), light yellowish-brown (10YR 6/4)

\section{Windsor Formation}

Sand, medium to coarse, pale-yellowishgray (5Y 8/2); contains subrounded to rounded quartz granules and $<1$ percent very fine, dark, heavy mineral grains

Sand, medium to coarse; pale grayish orange pink (5YR 8/2) grading down to pale yellowish brown (10YR 6/2) at $48 \mathrm{ft}$; subrounded to rounded quartz granules throughout; subrounded quartz pebbles up to $1 \mathrm{~cm}$ in diameter in basal foot 


\section{Tar Heel Formation}

Clay, silty, micaceous, very stiff, dense, dark-olive-gray (5Y 3/1); large

lump of pyrite.

Base of dune sand:

Base of Windsor Formation:

$+79.5 \mathrm{ft}$ above sea level $+54 \mathrm{ft}$ above sea level

\section{Bottomed in Tar Heel Formation}




\section{Turkey Quadrangle}

TU-1-04: $0.98 \mathrm{mi}$ west of eastern quadrangle border, $4.97 \mathrm{mi}$ north of southern quadrangle border, east of Carltons Mill Run and west of Buckhall Creek, on western side of North Carolina State Road 1108, 0.30 mi north-northwest of intersection of North Carolina State Roads 1108 and 1112, in east-central 1/9th of map area (latitude $34.9471^{\circ} \mathrm{N}$., longitude $78.1416^{\circ} \mathrm{W}$.). Surface elevation $120 \mathrm{ft}$.

\section{LITHOLOGY}

DEPTH, IN FEET

\section{Waccamaw Formation, Bahramsville unit}

Sand; fine to medium with scattered fine grains of dark, heavy minerals; clean; dusky yellow (5Y 6/4) grading down to pale yellowish gray (5Y 8/2) at $1 \mathrm{ft}$

Sand, fine to coarse, poorly sorted, silty, slightly clayey, dark-yellowish-orange (10YR 6/6)

Silt, very clayey, yellowish-gray (5Y 7/2);

2 in. thick

Sand, fine, clean, thixotropic, yellowish-

orange (10YR 7/6); contains <1 percent very

fine, dark, heavy mineral grains; lower contact

gradational

Sand, fine to coarse, poorly sorted, yellowishgray $(5 Y 7 / 2)$

\section{UNCONFORMITY}

\section{Tar Heel Formation}

Silt, sandy (very fine), clayey; pale reddish brown $(10 R 5 / 6)$ with yellowish-gray (5Y 7/2) streaks grading down to pale olive gray $(5 Y 6 / 2)$ at $21 \mathrm{ft}$

Silt, very clayey, carbonaceous, micaceous; variably interlayered dark brownish gray (5YR 3/1), dark yellowish green (5GY 4/4), and dark gray ( $N 8.5)$.

Sand, fine, silty, light-olive-brown (5Y 5/4).

Silt, very clayey, carbonaceous, micaceous; variably interlayered dark brownish gray (5YR 3/1), dark yellowish green (5GY 4/4), and dark gray ( $N$ 8.5); 1-in.-diameter pyrite nodule and some sand-filled burrows 
Sand, fine to coarse, poorly sorted, very

lignitic, dark-brownish-gray (5YR 3/1).

$45-48$

Silt, very clayey, dense, dark-gray ( $N$ 3.5).

$48-51$

Base of Waccamaw Formation, Bahramsville unit:

$+101 \mathrm{ft}$ above sea level

Bottomed in Tar Heel Formation 
TU-2-04: $3.78 \mathrm{mi}$ west of eastern quadrangle border, $7.87 \mathrm{mi}$ north of southern quadrangle border, in vacant lot on south side of North Carolina Highway 24, 0.45 mi west-southwest of intersection of North Carolina Highway 24 and North Carolina State Road 1911 in town of Turkey, in north-central 1/9th of map area (latitude $34.9895^{\circ} \mathrm{N}$., longitude 78.1914 W.). Surface elevation $145 \mathrm{ft}$.

\section{LITHOLOGY}

DEPTH, IN FEET

\section{Varina Grove unit}

Sand, fine, well-sorted, clean; grayish yellow

(5Y 7/4) grading down through dark yellowish orange

(10YR 6/6) (3-3.5 ft), pale yellowish gray

$(5 Y 8 / 2)(3.5-4 \mathrm{ft})$, and orange (10YR 5/6)

(4-8 ft) to pale yellowish orange (10YR 8/6)

Silt, sandy (very fine), yellowish-gray (5Y 8/1);

4 in. thick

Sand, fine, silty, light-brown (5YR 5/6)

Sand; fine grading down to fine to medium;

orange pink (5YR 7/4) grading down through

yellowish orange (10YR 7/6) (14-16 ft)

to dark yellowish orange (10YR 6/6).

Sand, fine to medium, silty, clayey, pale-

yellowish-gray (5Y 8/2).

Sand, medium to coarse, silty, clayey, medium-

yellowish-brown (10YR 5/4)

\section{UNCONFORMITY}

\section{Tar Heel Formation}

Sand, very fine to fine, clayey, lignitic; much denser than unit above; medium dark gray $(N 4)$

Sand, fine to medium, silty; olive gray ( $5 Y 3 / 2)$

grading down to medium gray $(N 5)$; lower contact

somewhat gradational

Sand, very fine to fine, clayey, silty, lignitic;

abundant coarse mica; dark olive gray (5Y 3/1).

Base of Varina Grove unit:

$+119 \mathrm{ft}$ above sea level

\section{Bottomed in Tar Heel Formation}


TU-3-04: $6.28 \mathrm{mi}$ west of eastern quadrangle border, $4.18 \mathrm{mi}$ north of southern quadrangle border, on southwestern side of North Carolina State Road 1932, 0.06 mi south-southeast of 134-ft spot elevation at intersection of North Carolina State Road 1932 with dirt road trending northeast, 1.3 mi northwest of intersection of North Carolina State Roads 1932 and 1004 , in west-central 1/9th of map area (latitude $34.9357^{\circ} \mathrm{N}$., longitude $78.2352^{\circ} \mathrm{W}$.). Surface elevation $130 \mathrm{ft}$.

\section{LITHOLOGY}

DEPTH, IN FEET

\section{Waccamaw Formation, Bahramsville unit}

Sand, fine, well-sorted, silty, slightly clayey;

light yellowish brown (10YR 6/4) grading down

to dark yellowish orange (10YR 6/6)...

Sand; fine with scattered grains up to granule size; dark yellowish orange (10YR 6/6) grading

down to reddish brown $(10 R 5 / 6)$.

Sand, very fine, silty, clayey; denser than interval above; yellowish gray ( $5 Y 7 / 2)$ grading down to orange (10YR 5/6)

Sand, fine, silty, orange (10YR 5/6); lower contact gradational.

Sand, fine to medium, silty, soft; orange

(10YR 5/6) grading down to medium brown $(5 Y R 4 / 6)$ at $14 \mathrm{ft}$..

\section{Tar Heel Formation}

Sand, very fine to fine, very clayey and silty, dense, stiff, micaceous; abundant wood fragments; light yellowish brown (10YR 6/4) in top 3 in., then grading down rapidly to dark olive gray (5Y 3/1)

Base of Waccamaw Formation, Bahramsville unit:

\section{Bottomed in Tar Heel Formation}


TU-4-04: 4.76 mi west of eastern quadrangle border, 3.18 mi north of southern quadrangle border, in Six Runs Creek valley, 0.05 mi south of North Carolina State Road 1004 on dirt road (not on map) located 0.3 mi east of North Carolina State Road 1004 bridge over Six Runs Creek, in west-central 1/9th of map area (latitude $34.9213^{\circ} \mathrm{N}$., longitude $78.2086^{\circ} \mathrm{W}$.). Surface elevation $74 \mathrm{ft}$.

\section{LITHOLOGY}

DEPTH, IN FEET

\section{Alluvium}

Sand, fine, well-sorted, silty; dark yellowish

brown (10YR 4/4) grading down through

medium olive brown (5Y 4/6) (1-3 ft)

to light yellowish brown (10YR 6/4)

Sand; medium grading down through medium

and coarse to coarse to very coarse and granular;

slightly silty; soft; very pale orange (10YR 8/2)

grading down to pale olive gray ( $5 Y 7 / 1)$;

rounded $1 \mathrm{~cm}$ pebble at base.

\section{Tar Heel Formation}

Silt, very clayey, stiff, olive-gray (5Y 4/1)

Sand, fine to medium; abundant large mica

flakes; sparsely lignitic; dark greenish gray

(5GY 4/1)

Silt, very clayey, stiff, lignitic, olive-gray

(5Y 4/1)

\section{Base of alluvium:}

$+58 \mathrm{ft}$ above sea level

\section{Bottomed in Tar Heel Formation}


TU-5-04: $3.34 \mathrm{mi}$ west of eastern quadrangle border, $1.82 \mathrm{mi}$ north of southern quadrangle border, north of Stewarts Creek, on northern side of North Carolina State Road 1942 opposite dirt road leading southwest to cemetery, $0.7 \mathrm{mi}$ east-southeast of junction of North Carolina State Roads 1942 and 1943, in south-central 1/9th of map area (latitude $34.9015^{\circ} \mathrm{N}$., longitude $78.1835^{\circ} \mathrm{W}$.). Surface elevation $104 \mathrm{ft}$.

\section{LITHOLOGY}

DEPTH, IN FEET

\section{Windsor Formation}

Sand, fine, well-sorted; dark yellowish brown $(10 Y R$ 4/2) grading down through light yellowish brown (10YR 6/4) to medium yellowish brown (10YR 5/4) with dark-yellowish-brown (10YR 4/2) mottles

Sand, fine, well-sorted, slightly silty; dark yellowish orange (10YR 6/6) grading down through light yellowish gray (5Y 8/4)

(4-5 ft) and dark yellowish orange (10YR 6/6)

(5-6 ft) to grayish orange pink (5YR 7/2)

Sand; medium to coarse, dominantly medium, with abundant rounded quartz granules and pebbles up to $2 \mathrm{~cm}$ in diameter; grayish orange pink (5YR 7/2)

\section{Waccamaw Formation, Bahramsville unit}

Sand, fine to medium, silty; grayish orange (10YR 7/2) grading down through pale yellowish brown (10YR 6/2) (14-17ft) and pale greenish yellow (10Y 8/2) (17-19ft) to medium yellow (5Y 7/6)..

Sand, fine to medium, dark-grayish-yellow

(10Y 7/4)

\section{UNCONFORMITY}

\section{Tar Heel Formation}

Silt, very clayey, micaceous, lignitic; orange (10YR 5/6) in upper 4 in. then grades rapidly to dark olive gray (5Y 3/1); lower contact gradational

Sand, very fine to fine, clayey, silty, very

micaceous, dark-olive-gray (5Y 3/1)

Base of Windsor Formation:

Base of Waccamaw Formation, Bahramsville unit:
$+93 \mathrm{ft}$ above sea level

$+80 \mathrm{ft}$ above sea level

\section{Bottomed in Tar Heel Formation}


TU-6-08: $0.29 \mathrm{mi}$ west of eastern quadrangle border, $7.38 \mathrm{mi}$ north of southern quadrangle border, on southern side of unnumbered dirt road, $0.13 \mathrm{mi}$ west-southwest of 145 -ft spot elevation on North Carolina State Road 1111, in northeastern 1/9th of map area (latitude $34.9815^{\circ} \mathrm{N}$., longitude $78.1325^{\circ} \mathrm{W}$.). Surface elevation $138 \mathrm{ft}$.

\section{LITHOLOGY}

DEPTH, IN FEET

\section{Varina Grove unit}

Sand, very fine to fine, silty, plinthitic, light-yellowish-

brown $(10 Y R 6 / 4)$

Sand, very fine to fine, silty, clayey; light yellowish

brown (10YR 6/4) grading down through dark yellowish

orange (10YR 6/6) with pale-yellowish-gray (5Y 8/2)

mottles and pale yellowish gray ( $5 Y$ 8/2) with dark-

yellowish-orange (10YR 6/6) mottles to pale yellowish brown

$(10 Y R 6 / 2)$

Silt, very clayey, sandy (very fine), dense, sticky;

yellowish orange (10YR 7/6) grading down to pale

greenish gray $(5 G 9 / 1)$....

Sand, fine to coarse, poorly sorted, silty; clayey grading

down to slightly clayey; pale greenish gray (5G 9/1)

Sand, fine to very coarse, very poorly sorted, granular, silty,

pale-olive (10Y 6/2); lower contact somewhat gradational .

Sand, fine to medium; contains 1-2 percent very fine, dark, heavy mineral grains; silty; light brown (5YR 5/6);

granular in basal foot...

\section{UNCONFORMITY}

\section{Chowan River Formation, Coharie Member}

Sand, fine to medium, silty, slightly clayey, micaceous, glauconitic; denser than unit above; dark grayish green (5GY 4/2) grading down through dark grayish yellow green $(5 G Y 6 / 2)$ to dark greenish gray (5GY $3 / 1)$ in basal $2 \mathrm{ft}$.

\section{Tar Heel Formation}

Clay, silty, micaceous, stiff, very dense, olive-gray $(5 Y 4 / 2)$.

Base of Varina Grove unit:

Base of Chowan River Formation, Coharie Member:

$+119 \mathrm{ft}$ above sea level

$+102 \mathrm{ft}$ above sea level

\section{Bottomed in Tar Heel Formation}


TU-7-08: $3.79 \mathrm{mi}$ west of eastern quadrangle border, $4.42 \mathrm{mi}$ north of southern quadrangle border, on southern side of unnumbered dirt road, $0.06 \mathrm{mi}$ west of $147-\mathrm{ft}$ spot elevation on North Carolina State Road 1004, in central 1/9th of map area (latitude $34.9357^{\circ} \mathrm{N}$., longitude $78.2352^{\circ} \mathrm{W}$.). Surface elevation $146 \mathrm{ft}$.

\section{LITHOLOGY}

DEPTH, IN FEET

\section{Dune sand}

Sand, fine, well-sorted, silty, increasingly

clayey downward; yellowish brown

(10YR 5/2) grading down through light yellowish

brown (10YR 6/4) and dark yellowish orange

(10YR 6/6) to yellowish gray (5Y 8/1).

Sand, fine, silty; denser than interval above; pale

yellowish brown $(10 Y R$ 7/2) grading to

grayish orange (10YR 7/4) at $3 \mathrm{ft}$

Sand, fine, slightly silty, soft, pale-orange

(10YR 7.5/2)

Sand, fine, soft, thixotropic; pale orange

(10YR 7.5/2) grading down through very pale

brown (5YR 6/2) (9-11 ft) to dusky

yellowish brown (10YR 2/2)

UNCONFORMITY

\section{Waccamaw Formation, Bahramsville unit}

Sand, fine to medium, silty, clayey, very pale brown (5YR 6/2); stiffer and denser

than sand above.

Sand; fine to medium grading down to fine to

coarse; poorly sorted with scattered

rounded quartz granules and small 0.5-

cm-diameter pebbles in basal $2 \mathrm{ft}$; silty;

slightly clayey; yellowish gray (5Y 8/1)

\section{Chowan River Formation, Coharie Member}

Sand, very fine to fine, silty, clayey,

micaceous, slightly sticky; denser than

unit above; dark orange (10YR 6/8) grading down

through yellowish gray (5Y 7/2) (25-25.5 ft) to

bright orange (10YR 7/8).

Base of dune sand:

Base of Waccamaw Formation, Bahramsville unit:

Bottomed in Chowan River Formation, Coharie Member
$+131 \mathrm{ft}$ above sea level

$+123 \mathrm{ft}$ above sea level 


\section{Wallace West Quadrangle}

WW-1-04: $4.03 \mathrm{mi}$ west of eastern quadrangle border, $4.40 \mathrm{mi}$ north of southern quadrangle border, at entrance to dirt road on western side of North Carolina State Road 1301, at intersection with 67-ft spot elevation, in central 1/9th of map area (latitude $34.6891^{\circ} \mathrm{N}$., longitude $78.0703^{\circ} \mathrm{W}$.). Surface elevation 67 feet.

\section{LITHOLOGY}

DEPTH, IN FEET

Road fill $0-1$

\section{UNCONFORMITY}

\section{Charles City Formation}

Sand, very fine, slightly silty and clayey; dusky yellowish brown (10YR 2/2) on light olive gray (5Y 6/1)

Sand, very fine, clayey, silty; light yellowish

brown (10YR 6/4) with light-olive-gray

(5Y 6/1) mottles grading down through light brown

(5YR 5/6) (5-6 ft) to yellowish orange

(10YR 7/6) with light-olive-gray (5Y 6/1) mottles

Sand, fine, slightly silty and clayey,

yellowish-gray (5Y 7/2)

Sand fine to medium grading down to fine;

silty; greenish gray (5GY 6/1)

Silt, clayey, sandy (very fine), dark-greenishgray $(5 G Y 4 / 1)$

Peat, dusky-yellowish-brown (10YR 2/2);

wood fragments.

Sand, fine, silty, olive-gray (5Y 4/2);

sparse wood fragments at base

\section{Windsor Formation}

Silt, clayey, massive, medium-greenishgray ( $5 G 5 / 1)$; burrows at top filled with sand from unit above; no basal coarse

lag bed, but scattered rounded quartz and phosphate pebbles up to $1 \mathrm{~cm}$ in diameter on basal contact. 


\section{Bladen Formation}

Sand; fine to medium grading down to fine, silty; clayey grading down to very clayey; olive gray ( $5 Y 3 / 2)$; rounded pyrite nodule

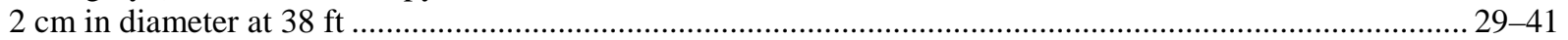

Base of Charles City Formation:

Base of Windsor Formation:

$+43 \mathrm{ft}$ above sea level $+38 \mathrm{ft}$ above sea level

\section{Bottomed in Bladen Formation}


WW-2-04: $1.33 \mathrm{mi}$ west of eastern quadrangle border, $7.59 \mathrm{mi}$ north of southern quadrangle border, at southern end of dead-end road, $0.08 \mathrm{mi}$ northwest of cemetery, $0.38 \mathrm{mi}$ northwest of "P" in "PENDER CO." label on map, in northeastern 1/9th of map area (latitude $34.7353^{\circ} \mathrm{N}$., longitude $78.0231^{\circ} \mathrm{W}$.). Surface elevation $47 \mathrm{ft}$.

LITHOLOGY

DEPTH, IN FEET

Road fill $0-1$

\section{UNCONFORMITY}

\section{Donoho Creek Formation}

Sand, fine to medium, silty, humic; dusky yellowish brown (10YR $2 / 2)$ grading down through pale yellowish brown (10YR 6/2), pale brownish gray (5YR 7/1), and medium olive gray $(5 Y 5 / 1)$ to dark olive gray (5Y 3/1)

Sand, fine to medium, poorly sorted; more angular than interval above; silty; humic; dark olive gray (5Y 3/1); silt and clay content increases downward.

Sand, fine to medium, subangular to angular, poorly sorted, silty; interbedded with fine sand, clayey, silty, with sparse shells;

\section{Bottomed in Donoho Creek Formation}


WW-3-04: 5.79 mi west of eastern quadrangle border, $6.40 \mathrm{mi}$ north of southern quadrangle border, on dirt road 0.2 mi north-northwest of junction of North Carolina State Roads 1303 and 1001, in northwestern 1/9th of map area (latitude $34.7178^{\circ} \mathrm{N}$., longitude $78.1012^{\circ} \mathrm{W}$.). Surface elevation $72 \mathrm{ft}$.

\section{LITHOLOGY}

DEPTH, IN FEET

\section{Charles City Formation}

Sand, very fine, silty, clayey; dark yellowish orange $(10 Y R$ 6/6) grading down through light brown (5YR 5/6) (2-4 ft) to light brown (5YR 5/6)

with yellowish-gray $(5 Y 7 / 2)$ mottles....

Sand; very fine grading rapidly down to fine to medium; silty; yellowish orange (10YR 7/6)

grading down to dark yellowish orange

(10YR 6/6)

Silt, clayey, sandy (very fine), greasy-textured, very sticky, soft, medium-greenish-gray ( $5 G 5 / 1)$

\section{UNCONFORMITY}

\section{Bladen Formation}

Sand, fine to medium, silty, clayey, olive-gray (5Y 3/2); denser than unit above; sparsely shelly in basal $2 \mathrm{ft}$.

\section{Bottomed in Bladen Formation}


WW-4-04: $1.52 \mathrm{mi}$ west of eastern quadrangle border, $2.48 \mathrm{mi}$ north of southern quadrangle border, on northern side of North Carolina State Road 1319, 0.56 mi east-northeast of intersection of North Carolina State Roads 1319 and 1324, 1.43 mi east-northeast of the "a" in "Penderlea" label on map, in southeastern 1/9th of map area (latitude $34.6612^{\circ} \mathrm{N}$., longitude $78.0259^{\circ} \mathrm{W}$.). Surface elevation $67 \mathrm{ft}$.

\section{LITHOLOGY}

DEPTH, IN FEET

\section{Charles City Formation}

Sand, very fine, silty, clayey; dusky yellowish brown $(10 Y R 2 / 2)$ on pale yellowish brown (10YR 6/2) with pale-olive-brown (5Y 6/6) mottles

Silt, clayey, sandy (very fine), stiff, dense;

light brown (5YR 5/6) with pale-olive-

gray (5Y 7/1) mottles; lower contact gradational

Sand, very fine, silty, pale-olive-gray (5Y 7/1)

Sand, very fine, silty, soft, yellowish-orange

(10YR 7/6); lower contact gradational.

Sand, fine, silty, yellowish-orange (10YR 7/6).....

Sand, fine to medium, slightly silty, olivegray $(5 Y 4 / 1)$

\section{UNCONFORMITY}

\section{Windsor Formation}

Silt, very clayey, sandy (very fine), greasy, dark-greenish-gray (5GY 4/1)

Sand; fine to medium with dense clay-silt

matrix; very dark greenish gray (5GY 3/1).

Sand, fine to medium, silty; softer than interval above; dark greenish gray (5GY 4/1)

\section{Donoho Creek Formation}

Sand; very fine to fine interbedded with fine to medium; silty; dark olive gray (5Y 3/1)

Base of Charles City Formation:
Base of Windsor Formation:

\section{Bottomed in Donoho Creek Formation}

$+29 \mathrm{ft}$ above sea level

$+21 \mathrm{ft}$ above sea level 
WW-5-04: $6.30 \mathrm{mi}$ west of eastern quadrangle border, $0.65 \mathrm{mi}$ north of southern quadrangle border, on western side of U.S. Highway 421, $0.1 \mathrm{mi}$ south of junction of U.S. Highway 421 and North Carolina Highway 11, in southwestern $1 / 9$ th of map area (latitude $34.6348^{\circ} \mathrm{N}$., longitude $78.1097^{\circ} \mathrm{W}$.). Surface elevation $57 \mathrm{ft}$.

\section{LITHOLOGY}

DEPTH, IN FEET

\section{Charles City Formation}

Sand, very fine, silty, clayey, pale-olive-

brown $(5 Y$ 6/6) ......

Silt, clayey, sandy (very fine), dense, stiff;

pale olive brown (5Y 6/6) grading down through

yellowish orange (10YR 7/6) (3-4 ft)

to dark yellowish gray $(5 Y$ 7/1).

Sand, very fine, silty, dusky-yellow

$(5 Y 6 / 4)$

\section{Windsor Formation}

Silt, clayey, sandy (very fine), stiff, dense;

medium yellowish brown (10YR 5/4)

with pale-olive (10Y 6/2) mottles

Silt, clayey, stiff, dense; pale olive

(10Y 6/2) with grayish-olive (10Y 4/2) mottles

grading down through grayish green ( $5 G 5 / 2)$

with greenish-gray ( $5 G$ 6/1) mottles (13 to 23

$\mathrm{ft})$ to dark greenish gray $(5 G 4 / 1)^{*}$

Sand, fine to medium, dark-greenish-gray

(5G 4/1); pyrite pebbles and an oyster

fragment on basal contact

\section{Bladen Formation}

Sand, fine to medium, silty, dark-olive-gray

(5Y 2/2); clay content increases downward;

scattered pyrite nodules; sparsely

shelly below $38 \mathrm{ft}$

Base of Charles City Formation:

Base of Windsor Formation:

\section{Bottomed in Bladen Formation}

*Recovered Pleistocene calcareous nannofossil assemblage at $31 \mathrm{ft}$

(Jean M. Self-Trail, USGS, oral commun., 2004).
$+49 \mathrm{ft}$ above sea level

$+24 \mathrm{ft}$ above sea level 


\section{Warsaw South Quadrangle}

WS-1-04: $5.06 \mathrm{mi}$ west of eastern quadrangle border, $7.64 \mathrm{mi}$ north of southern quadrangle border, $200 \mathrm{ft}$ east of Seaboard Railroad, $1.0 \mathrm{mi}$ south of northern quadrangle border, in northwestern 1/9th of map area (latitude $34.9860^{\circ} \mathrm{N}$., longitude $78.0888^{\circ} \mathrm{W}$.). Surface elevation $152 \mathrm{ft}$.

\section{LITHOLOGY}

DEPTH, IN FEET

\section{Varina Grove unit}

Sand, fine to medium, silty, humic, dusky-

brown (5YR 2/2)

Sand; fine grading down to very fine; dark yellowish gray (5Y 6/2) grading down through dark yellowish brown (10YR 5/2) (4-5

$\mathrm{ft})$ to dark grayish yellow (5Y 7/2)

Sand, very fine to fine, silty; dusky yellow (5Y 6/4) grading down through grayish orange (10YR 7/4) (9-11 ft) to dark yellowish orange (10YR 6/6)

Sand, very fine to fine, silty, clayey, orange-

pink (10R 6/4)

Sand, fine, silty, clayey, grayish-orange-

pink (10R 8/2)

Sand; fine to medium grading down to fine to very coarse; very poorly sorted; silty; clayey; medium greenish gray (5G 5/1); small clayball at $34 \mathrm{ft}$.....

Sand; medium grading down to medium to coarse; granular; medium grayish yellow (5Y $7 / 4)$

\section{UNCONFORMITY}

\section{Tar Heel Formation}

Clay, silty, dense, stiff, lignitic, very dark greenish gray (5GY 3/1); upper foot burrowed, filled with matrix from unit above

\section{Base of Varina Grove unit:}

$+114 \mathrm{ft}$ above sea level

\section{Bottomed in Tar Heel Formation}


WS-2-04: $1.48 \mathrm{mi}$ west of eastern quadrangle border, $8.56 \mathrm{mi}$ north of southern quadrangle border, at entrance of dirt road on southern side of North Carolina State Road 1375, $200 \mathrm{ft}$ south of northern quadrangle border, in northeastern 1/9th of map area (latitude $34.9999^{\circ} \mathrm{N}$., longitude $78.0258^{\circ} \mathrm{W}$.). Surface elevation $142 \mathrm{ft}$.

\section{LITHOLOGY}

DEPTH, IN FEET

\section{Varina Grove unit}

Sand, fine, well-sorted, clean, light-olivebrown $(5 Y 5 / 5)$.

Sand, fine, silty; yellowish orange (10YR 7/6)

grading down to very light gray $(N 8)$

Sand, fine to medium, silty, slightly clayey;

yellowish orange (10YR 7/6) grading down through

dark yellowish orange (10YR 6/6) (11-16

$\mathrm{ft}$ ) to light brown (7.5YR 5/6); lower contact

somewhat gradational

Sand, fine to coarse, silty, light-grayish-

orange (10YR 8/4); quartz pebbles and

discoids up to $3 \mathrm{~cm}$ in diameter.

\section{UNCONFORMITY}

\section{Chowan River Formation, Coharie Member}

Sand, very fine to fine with scattered medium grains, silty, clayey; light grayish orange (10YR 8/4) grading down to dark yellowish orange (10YR 5/6) at $25 \mathrm{ft}$

Sand, medium, silty, clayey, darkyellowish-orange (10YR 5/6); flattened discoidal mudballs up to $2 \mathrm{~cm}$ in diameter reworked from bed below

\section{Tar Heel Formation}

Silt, very clayey, dense, lignitic; overlies medium to coarse, lignitic sand; light grayish olive (10Y 5/2)

Base of Varina Grove unit:

Base of Chowan River Formation, Coharie Member:
$+122 \mathrm{ft}$ above sea level

$+108 \mathrm{ft}$ above sea level

\section{Bottomed in Tar Heel Formation}


WS-3-04: $3.51 \mathrm{mi}$ west of eastern quadrangle border, $4.73 \mathrm{mi}$ north of southern quadrangle border, at southern end of North Carolina State Road 1907, on northern side of Interstate Route 40 and $1.12 \mathrm{mi}$ south of junction of North Carolina State Roads 1907 and 1107, in central 1/9th of map area (latitude $34.9441^{\circ}$ N., longitude $78.0615^{\circ} \mathrm{W}$.). Surface elevation $110 \mathrm{ft}$.

LITHOLOGY

DEPTH, IN FEET

Road fill $0-2$

\section{UNCONFORMITY}

\section{Alluvium}

Muck, odiferous, fine (sandy), silty, clayey;

dusky yellowish brown (10YR 2/2) grading

down to grayish brown (5YR $3 / 2)$.

Sand, fine, silty, clayey, grayish-brown (5YR 3/2); quartz granules concentrated at base

\section{UNCONFORMITY}

\section{Chowan River Formation, Coharie Member}

Sand, fine, dark-grayish-green (5GY 4/2);

detrital mudballs and pyrite clasts up to $1 \mathrm{~cm}$

in diameter at base

\section{UNCONFORMITY}

\section{Tar Heel Formation}

Silt, very clayey, dense, lignitic, medium-

olive-gray (5Y 5/1)

Base of alluvium:

Base of Chowan River Formation, Coharie Member:
$+99 \mathrm{ft}$ above sea level

+95 $\mathrm{ft}$ above sea level

\section{Bottomed in Tar Heel Formation}


WS-4-04: $0.41 \mathrm{mi}$ west of eastern quadrangle border, $2.59 \mathrm{mi}$ north of southern quadrangle border, on dirt road $0.25 \mathrm{mi}$ southwest of junction with North Carolina State Road 1923, 0.25 mi south-southwest of 130-ft spot elevation on North Carolina State Road 1923, in southeastern $1 / 9$ th of map area (latitude $34.9127^{\circ} \mathrm{N}$., longitude $78.0070^{\circ} \mathrm{W}$.). Surface elevation $113 \mathrm{ft}$.

\section{UNCONFORMITY}

\section{Waccamaw Formation, Bahramsville unit}

Sand, fine, well-sorted, silty; grades down to fine, well-sorted, clean; dark yellowish orange (10YR 6/6) grading down to very light yellowish gray (5Y 9/1).

Sand, very fine, silty; denser than interval above;

very light yellowish gray ( $5 Y$ 9/1).

Silt, sandy (very fine), clayey, yellowish-gray

(5Y 8/1)

Sand, very fine, silty, clayey; rapidly grades to fine to medium, silty sand; dark yellowish gray $(5 Y 6 / 2)$

\section{Castle Hayne Limestone}

Calcarenite, fine, quartzose, silty, micaceous, medium-olive-gray (5Y 4/1); sparse shell fragments near base

Sand, fine to medium, silty, calcareous, shelly, pale-olive-gray ( $5 Y 7 / 1)$; echinoid spines and bryozoans; abundant phosphate granules at base*

\section{Bladen Formation}

Clay, silty; sandy (very fine) grading down to very fine, clayey, silty sand; dark olive gray $(5 Y 3 / 1)$

Sand, medium to coarse, glauconitic, silty, dark-olive-gray (5Y 3/1) to dark-grayishgreen $(5 G 4 / 2)$ 


\section{Tar Heel Formation}

Sand, fine to medium, clayey, dense, lignitic,

dark-olive-gray (5Y 3/1); locally abundant pyrite lumps 44-51

Base of Waccamaw Formation, Bahramsville unit:

Base of Castle Hayne Limestone:

Base of Bladen Formation:

\section{Bottomed in Tar Heel Formation}

*Recovered poorly preserved Tertiary calcareous nannofossils at $34 \mathrm{ft}$ (Jean M. Self-Trail, USGS, oral commun., 2004).
$+95 \mathrm{ft}$ above sea level $+78 \mathrm{ft}$ above sea level $+69 \mathrm{ft}$ above sea level 
WS-5-04: $5.60 \mathrm{mi}$ west of eastern quadrangle border, $1.22 \mathrm{mi}$ north of southern quadrangle border, along dirt road (not on map) $0.05 \mathrm{mi}$ south-southwest of North Carolina State Road 1104, $0.38 \mathrm{mi}$ southeast of 126-ft spot elevation on North Carolina State Road 1104, in southwestern 1/9th of map area (latitude $34.8930^{\circ} \mathrm{N}$., longitude $78.0982^{\circ} \mathrm{W}$.). Surface elevation $125 \mathrm{ft}$.

\section{LITHOLOGY}

DEPTH, IN FEET

\section{Waccamaw Formation, Bahramsville unit}

Sand, fine to medium; silt content increases downward; dark yellowish brown (10YR 4/2) grading down through medium yellowish orange (10YR 7/6) to dark yellowish orange (10YR 6/6).

Sand, fine to medium, clean, thixotropic; light yellowish brown (10YR 6/4) grading down to yellowish gray (5Y 8/1)

Sand, very fine, clayey, silty, pale-orange $(10 Y R$ 8/2)

Sand, fine to medium, thixotropic, paleorange $(10 Y R 8 / 2)$.

Sand, fine to medium, silty, clayey; denser than interval above; light olive gray ( $5 Y$ 6/1) grading

down to grayish orange pink (5YR 7/2).

Sand, fine to medium, clean, pale-orange (10YR $7 / 2)$

Sand, medium, silty, thixotropic, humic, grayish-brown (5YR 3/2).

Peat, sandy, greasy, dusky-brown (5YR 1/2); scattered wood fragments

Sand, fine to medium, peaty, humic, thixotropic, dusky-brown (5YR 1/2).

Sand, fine to medium, silty, clayey, sticky, grayish-orange-pink (5YR 7/2)

Sand, fine to medium, soft, thixotropic, dusky-brown (5YR 1/2)

Sand, fine to medium, soft, kaolinitic, pale-brownish-gray (5YR 7/1) 


\section{Tar Heel Formation}

Sand, very fine, clayey, silty, darkyellow (5Y 6/6).

Sand, very fine to fine, silty, clayey;

olive gray $(5 Y 4 / 2)$ with

dark-yellowish-orange (10YR 6/6) streaks,

light olive brown (5Y 5/4), and

grayish green (10GY 5/2) .....

Base of Waccamaw Formation, Bahramsville unit:

$+63 \mathrm{ft}$ above sea level

\section{Bottomed in Tar Heel Formation}


WS-6-04: $4.19 \mathrm{mi}$ west of eastern quadrangle border, $0.16 \mathrm{mi}$ north of southern quadrangle border, on southwestern side of Natural Well (erroneously shown on map without hachured contour lines to indicate a sinkhole), $0.16 \mathrm{mi}$ north of southern quadrangle border and 0.3 mi southeast of North Carolina State Road 1003, in south-central 1/9th of map area (latitude $34.8775^{\circ} \mathrm{N}$., longitude $78.0734^{\circ} \mathrm{W}$.). Surface elevation $132 \mathrm{ft}$.

\section{LITHOLOGY}

DEPTH, IN FEET

\section{Waccamaw Formation, Bahramsville unit}

Sand, fine, well-sorted, clean; dark yellowish brown $(10 Y R$ 4/2) over medium yellowish orange (10YR 7/6) .

Sand; fine grading down to fine to medium with a minor coarse fraction; slightly silty; dark yellowish orange (10YR 6/6) grading down to very pale orange $(10 Y R 8 / 2)$...

\section{Duplin Formation}

Sand, fine, silty, clayey; grayish orange (10YR 7/4) grading down through light brown $(5 Y R$ 5/6) (8-8.5 ft) to dark greenish gray $(5 G Y 4 / 1)$

Silt, sandy (very fine), slightly clayey, very shelly, medium-greenish-gray ( $5 G Y 5 / 1$ )

\section{Castle Hayne Limestone}

Calcisiltite to fine calcarenite, silty, darkgrayish-yellow green (5GY 6/2); locally indurated into massive lumps*

\section{Base of Waccamaw Formation, Bahramsville unit: Base of Duplin Formation:}

$+125 \mathrm{ft}$ above sea level

$+117 \mathrm{ft}$ above sea level

\section{Bottomed in Castle Hayne Limestone}

*Recovered Eocene calcareous nannofossils at $18 \mathrm{ft}$ representing Zone NP 16 and at $39 \mathrm{ft}$ representing Zone NP 16/17 (Jean M. Self-Trail, USGS, oral commun., 2004). 
WS-7-04: $2.89 \mathrm{mi}$ west of eastern quadrangle border, $0.87 \mathrm{mi}$ north of southern quadrangle border, $0.05 \mathrm{mi}$ east of U.S. Highway 117 and $0.1 \mathrm{mi}$ southeast of the southern town border of Magnolia, in south-central 1/9th of map area (latitude $34.8877^{\circ} \mathrm{N}$., longitude $78.0505^{\circ} \mathrm{W}$.). Surface elevation $128 \mathrm{ft}$.

\section{LITHOLOGY}

DEPTH, IN FEET

\section{Waccamaw Formation, Bahramsville unit}

Sand, fine to medium, silty, slightly clayey;

dusky yellowish brown (10YR 2/2) grading

down to dark reddish brown (5YR 3/4).....

Sand, fine to medium, silty, slightly clayey;

dark yellowish brown (10YR 4/2) grading

down to yellowish brown (10YR 5/2);

lower contact gradational

Sand, fine to coarse, poorly sorted, silty;

yellowish gray (5Y 8/1) grading down to

light greenish gray (5GY 8/1).

\section{Varina Grove unit}

Sand, very fine to medium, poorly sorted; grades down to medium to coarse; clayey; slightly greasy texture; silty; medium dark gray $(N 4)$; phosphate granules and quartz discoids up to $3 \mathrm{~cm}$ in diameter on basal contact

\section{Bladen Formation}

Sand, fine to medium, very calcareous, sparsely shelly; grayish olive (10YR 4/2)

grading down to olive gray ( $5 Y 3 / 2)$

Sand, fine to medium, calcareous, subangular to subrounded, clayey, silty, micaceous, darkgreenish-gray (5GY 3/1).

Base of Waccamaw Formation, Bahramsville unit: Base of Varina Grove unit:

\section{Bottomed in Bladen Formation}

$+114 \mathrm{ft}$ above sea level

$+111 \mathrm{ft}$ above sea level 
WS-8-04: $1.79 \mathrm{mi}$ west of eastern quadrangle border, $1.39 \mathrm{mi}$ north of southern quadrangle border, in vacant lot on south side of North Carolina State Road 1912, 0.15 mi west of intersection of North Carolina State Roads 1912 and 1911, in southeastern 1/9th of map area (latitude $34.8954^{\circ} \mathrm{N}$., longitude $78.0312^{\circ} \mathrm{W}$.). Surface elevation $120 \mathrm{ft}$.

\section{LITHOLOGY}

DEPTH, IN FEET

\section{Waccamaw Formation, Bahramsville unit}

Sand; fine to medium, dominantly fine; clean; humic at top; olive black (5Y 2/1) grading

down to pale yellowish brown (10YR 6/2).

Sand; fine to medium, dominantly fine; clean;

dusky yellowish brown (10YR 2/2) grading down

through dark yellowish brown (10YR 4/2)

(3-4 ft) to pale yellowish brown

(10YR 6/2)

Sand; fine to medium grading down to medium to coarse; light greenish gray (5GY 7/1) grading down to medium greenish gray (5GY 5/1) .

\section{Duplin Formation}

Sand, fine, silty, greenish-gray (5GY 6/1);

very shelly, including Mulinia

\section{Bladen Formation}

Calcarenite, quartzose, fine to medium;

indurated at top; sparsely shelly; olive gray

(5Y 4/1) grading down to dark olive gray (5Y 3/1)

at $17 \mathrm{ft}$; sparsely micaceous in basal foot;

lower contact abrupt with lag shell fragments

and detrital nodules*

\section{Tar Heel Formation}

Sand, very fine to fine, micaceous, silty, dark-olive-gray (5Y 3/1); sparse wood fragments.

Base of Waccamaw Formation, Bahramsville unit:

Base of Duplin Formation:

Base of Bladen Formation:

\section{Bottomed in Tar Heel Formation}

*Recovered Upper Cretaceous (Campanian) calcareous nannofossil Zone CC 21 assemblage at 35 ft (Jean M. SelfTrail, USGS, oral commun., 2004).
$+108 \mathrm{ft}$ above sea level
$+106 \mathrm{ft}$ above sea level
$+83 \mathrm{ft}$ above sea level 
WS-9-04: $3.36 \mathrm{mi}$ west of eastern quadrangle border, $3.52 \mathrm{mi}$ north of southern quadrangle border, on western side of chicken coops, $0.1 \mathrm{mi}$ west of North Carolina State Road 1909, $0.4 \mathrm{mi}$ south-southwest of junction of North Carolina State Roads 1909 and 1927, in central 1/9th of map area (latitude $34.9265^{\circ} \mathrm{N}$., longitude $78.0585^{\circ} \mathrm{W}$.). Surface elevation $140 \mathrm{ft}$.

\section{LITHOLOGY}

DEPTH, IN FEET

\section{Varina Grove unit}

Sand, very fine to fine, silty, slightly clayey; dark yellowish brown (10YR 4/2) over pale grayish orange (10YR 8/4).....

Sand, fine, silty; dark yellowish orange (10YR 6/6) grading down through yellowish orange (10YR 7/6) to pale yellowish brown (10YR $7 / 2)$

Sand, fine, silty, thixotropic; dark grayish yellow (5Y 7/4) grading down through grayish brown (5YR 3/2) (9-12 ft) and very pale brown $(5 Y R$ 6/2) (12-15 ft) to very pale yellowish brown $(10 Y R$ 6/2)

Sand; fine grading down to fine to medium; silty; clayey; very pale yellowish brown (10YR 6/2)

Sand, fine to medium, silty; yellowish gray (5Y 8/1) grading in basal foot to dusky yellow (5Y 6/4).

Sand, very fine to fine, silty, clayey; stiffer than interval above; dark yellowish orange (10YR 6/6)

\section{Bladen Formation?}

Impenetrable hard bed at 45

\section{Base of Varina Grove unit:}

\section{Bottomed on Bladen Formation?}


WS-10-05: $5.18 \mathrm{mi}$ west of eastern quadrangle border, $4.57 \mathrm{mi}$ north of southern quadrangle border, on northwestern side of North Carolina State Road 1107, 1.15 mi southwest of Carroll, in west-central 1/9th of map area (latitude $34.9413^{\circ} \mathrm{N}$., longitude $78.0908^{\circ} \mathrm{W}$.). Surface elevation $139 \mathrm{ft}$.

\section{LITHOLOGY}

DEPTH, IN FEET

\section{Varina Grove unit}

Sand, very fine to fine, silty, slightly clayey;

dark yellowish brown (10YR 3/2) over light

yellowish brown $(10 Y R$ 6/4)

Sand, fine, silty; medium grayish pink

( $5 R 7 / 2$ ) grading down through yellowish gray

(5Y 8/1) (4-8 ft) to yellowish orange

(10YR 7/6)

Sand, very fine, silty, clayey, yellowish-

orange (10YR 7/6)

Sand, very fine to fine, silty; very pale orange

(10YR 8/2) grading to pale grayish orange

$(10 Y R 8 / 4)$ at about $17 \mathrm{ft}$.....

Sand, very fine to medium, poorly sorted, silty,

clayey; dark yellowish orange (10YR 6/6)

grading down through pale grayish orange pink

(5YR 8/2) back to dark yellowish orange

(10YR 6/6)

\section{Castle Hayne Limestone}

Calcarenite, very fine to fine; pale yellowish gray $(5 Y 8 / 2)$ grading down to greenish gray (5GY 6/1) intermingled with greenish yellow (10Y 7/2) at about $27 \mathrm{ft}$; shell fragments.

Base of Varina Grove unit:

$+116 \mathrm{ft}$ above sea level

\section{Bottomed in Castle Hayne Limestone}


WS-11-05: $4.19 \mathrm{mi}$ west of eastern quadrangle border, $0.16 \mathrm{mi}$ north of southern quadrangle border, on dirt road (not shown on map) $0.15 \mathrm{mi}$ east-southeast of North Carolina State Road 1105, $0.40 \mathrm{mi}$ southeast of North Carolina State Road 1105 bridge over Buckhall Creek and 0.65 mi north-northeast of junction of North Carolina State Roads 1105 and 1113, in northwestern 1/9th of map area (latitude $34.9596^{\circ} \mathrm{N}$., longitude $78.1140^{\circ} \mathrm{W}$.). Surface elevation $133 \mathrm{ft}$.

\section{LITHOLOGY}

DEPTH, IN FEET

\section{Dune sand}

Sand, fine, soft; dark yellowish brown

(10YR 3/2) overlying $1 \mathrm{ft}$ of dark-

yellowish-brown peat. 0-6

\section{UNCONFORMITY}

\section{Waccamaw Formation, Bahramsville unit}

Sand, fine, slightly silty, thixotropic;

dusky yellowish brown (10YR 2/2)

grading down through dark yellowish brown

(10YR 4/4) intermingled with light yellowish

brown $(10 Y R 6 / 4)$ to pale olive gray

$(5 Y 7 / 1)$

Sand, fine, slightly silty, thixotropic, grayish-yellow (5Y 7/4).

Sand, fine, slightly silty, thixotropic;

pale olive (10Y 6/2) grading down

through dusky yellow (5Y 6/4) (20-

$25 \mathrm{ft}$ ) and dark greenish gray (5GY 4/1)

(25-27 ft) to dusky yellow green (5GY 5/2) ...

Sand, fine, micaceous, light-olive-

brown ( $5 Y 5 / 4)$; abundant very fine, dark,

heavy mineral grains

\section{Tar Heel Formation}

Sand, very fine, silty, clayey; dusky

yellowish orange $(10 Y R 5 / 6)$ with

light-olive-gray (5Y 5/2) mottles.

Sand, fine, micaceous, light-olive-

brown $(5 Y 5 / 4)$

Silt, very clayey, lignitic; dark greenish

gray (5GY 4/1) with dusky-yellowish-

orange $(10 Y R$ 5/6) mottles.

$35-36$

Base of Waccamaw Formation, Bahramsville unit:

$+104 \mathrm{ft}$ above sea level

\section{Bottomed in Tar Heel Formation}


WS-12-08: $3.13 \mathrm{mi}$ west of eastern quadrangle border, $7.53 \mathrm{mi}$ north of southern quadrangle border, at edge of field $200 \mathrm{ft}$ north of North Carolina State Road 1903, $0.22 \mathrm{mi}$ west of intersection of North Carolina State Roads 1903 and 1904 , in north-central 1/9th of map area (latitude $34.9845^{\circ} \mathrm{N}$., longitude $78.0552^{\circ} \mathrm{W}$.). Surface elevation $142 \mathrm{ft}$.

\section{LITHOLOGY}

DEPTH, IN FEET

\section{Varina Grove unit}

Sand, very fine, silty, clayey; dark yellowish brown $(10 Y R 3 / 2)$ overlying light yellowish brown $(10 Y R$ 6/4)

Sand, very fine to fine, silty, clayey; light olive gray (5Y 6/1) with grayish-orange (10YR 7/4) and light-brown (5YR 5/6) streaks

Sand; fine grading down to fine to medium; silty; light olive gray (5Y 6/1) with grayishorange (10YR 7/4) and light-brown (5YR 5/6) streaks grading down to dark greenish gray $(5 G Y 3 / 1)$ at $12 \mathrm{ft}$

Sand, fine to coarse, poorly sorted, very clayey and silty, dusky-greenish-gray (5GY 3/1)

Sand, medium to coarse, dusky-greenish-gray (5GY 3/1); abundant rounded quartz pebbles up to $6 \mathrm{~cm}$ long,

\section{UNCONFORMITY}

\section{Duplin Formation}

Coquina; mollusk shells in very fine to fine silty sand matrix; greenish gray (5GY 6/1).

\section{UNCONFORMITY}

\section{Bladen Formation}

Sand; very fine to fine grading down to fine and well-sorted; silty; calcareous; dark greenish gray ( $5 G Y 3 / 1)$; quartz and phosphate granules and pebbles up to 0.5 $\mathrm{cm}$ in diameter on basal contact* 


\section{Tar Heel Formation}

Sand, very fine to fine, silty, slightly clayey,

calcareous, dark-greenish-gray (5GY /3/1).

39-41

Base of Varina Grove unit:

$+119 \mathrm{ft}$ above sea level

Base of Duplin Formation:

$+110 \mathrm{ft}$ above sea level

Base of Bladen Formation:

$+103 \mathrm{ft}$ above sea level

\section{Bottomed in Tar Heel Formation}

*Recovered poorly preserved Upper Cretaceous (Campanian) calcareous nannofossil Zone CC 20-23 assemblage at $35 \mathrm{ft}$ (Jean M. Self-Trail, USGS, oral commun., 2008). 
WS-13-08: $5.92 \mathrm{mi}$ west of eastern quadrangle border, $3.23 \mathrm{mi}$ north of southern quadrangle border, $50 \mathrm{ft}$ southwest of North Carolina State Road 1107 along dirt road that leads southwest from 138-ft spot elevation on North Carolina State Road 1107 , in west-central 1/9th of map area (latitude $34.8775^{\circ} \mathrm{N}$., longitude $78.07348^{\circ} \mathrm{W}$.). Surface elevation $138 \mathrm{ft}$.

\section{LITHOLOGY}

DEPTH, IN FEET

\section{Waccamaw Formation, Bahramsville unit}

Sand, very fine to fine, silty, slightly clayey; grayish brown (5Y 3/2) grading down through pale yellowish brown (10YR 6/2) (4-6 in.)

to dark yellowish brown $(10 Y R 3 / 2)$

Sand; very fine to fine grading down to fine;

silty; olive gray ( $5 Y 4 / 2)$ grading to

grayish orange pink (5YR 7/2) at $4 \mathrm{ft}$

Sand, fine to medium, silty, slightly clayey,

pale-olive-gray (5Y 7/1) .

Sand, fine to coarse, poorly sorted, very silty

and clayey, sticky, dark-olive-gray (5Y 3/1)

\section{UNCONFORMITY}

\section{Duplin Formation}

Coquina, with very fine to fine quartz sand matrix; olive gray (5Y 4/1); shells include Dinocardium

Calcarenite, very shelly; interbedded with coquina with silty very fine quartz-sand matrix; grayish yellow (5Y 7/4) grading down to dark yellowish gray $(5 Y 6 / 2)$ at $26 \mathrm{ft}$; black quartz discoid $2 \mathrm{~cm}$ in diameter in basal foot

\section{UNCONFORMITY}

\section{Tar Heel Formation}

Sand; fine grading down to fine to medium; silty; slightly clayey; micaceous; very dark greenish gray (5GY 3/1)

Base of Waccamaw Formation, Bahramsville unit: Base of Duplin Formation:

\section{Bottomed in Tar Heel Formation}




\section{White Lake Quadrangle}

WL-1-07: $0.61 \mathrm{mi}$ west of eastern quadrangle border, $4.73 \mathrm{mi}$ north of southern quadrangle border, $50 \mathrm{ft}$ north of North Carolina Highway 41 on right side of driveway to abandoned house, $0.17 \mathrm{mi}$ west of where power line crosses North Carolina Highway 41, in east-central $1 / 9$ th of map area (latitude $34.6937^{\circ} \mathrm{N}$., longitude $78.3856^{\circ} \mathrm{W}$.). Surface elevation $77 \mathrm{ft}$.

\section{LITHOLOGY}

DEPTH, IN FEET

\section{Charles City Formation}

Sand, very fine to fine, very silty, slightly

clayey; medium yellowish brown (10YR 5/2)

grading rapidly down through light grayish orange

(10YR 8/4) to dark yellowish orange

(10YR 6/6)

Silt, very clayey, sandy (very fine); light grayish orange (10YR 8/4) with darkyellowish-orange (10YR 6/6) streaks grading

down to dark reddish brown (10R 3/6)

intermingled with yellowish gray (5Y 7/2)

and dark yellowish orange (10YR 6/6) at $4 \mathrm{ft}$

Sand, fine to medium, silty; dark reddish

brown $(10 R 3 / 6)$ intermingled with

yellowish gray (5Y 7/2) and dark yellowish

orange (10YR 6/6).

Sand; fine to medium grading down to medium to

coarse; yellowish gray (5Y 8/1); subrounded to

rounded below $15 \mathrm{ft}$

Sand; medium to coarse with subangular to subrounded quartz pebbles up to $2 \mathrm{~cm}$ in diameter; dark yellowish orange (10YR 6/6);

lower contact abrupt

\section{Tar Heel Formation}

Clay, sandy (very fine), silty, stiff, dense, slightly micaceous, sparsely lignitic, dark-olive-gray (5Y 3/1); contains a single 5 -mm-thick layer of fine to medium quartz sand.

\section{Bottomed in Tar Heel Formation}


WL-2-07: 3.79 mi west of eastern quadrangle border, $6.92 \mathrm{mi}$ north of southern quadrangle border, along abandoned loop of North Carolina Highway 210, $20 \mathrm{ft}$ northwest of 90-ft benchmark, along eastern margin of Reedy Branch Bay, in north-central 1/9th of map area (latitude $34.7255^{\circ} \mathrm{N}$., longitude $78.4412^{\circ} \mathrm{W}$.). Surface elevation $90 \mathrm{ft}$.

\section{LITHOLOGY}

DEPTH, IN FEET

\section{Dune sand}

Sand, fine to coarse, poorly sorted, subrounded,

soft, variably humic; brownish gray (5YR 4/1)

grading down through very pale orange (10YR 8/2)

(0.5-1 ft), pale yellowish brown (10YR 7/2) (1-2 ft),

and dusky brown (5YR 2/2) (2-2.5 ft) to

olive gray (5Y 4/2).

\section{Carolina Bay fill}

Silt, very fine to fine sandy, clayey, light-olive-

gray $(5 Y 6 / 1)$

Sand, very fine to medium, dominantly fine, poorly sorted, silty; brownish gray ( $5 Y R 5 / 1)$ grading down through grayish brown $(5 Y R 3 / 2)$ to light olive gray (5Y 5/2)

\section{UNCONFORMITY}

\section{Charles City Formation}

Silt, very clayey, greasy, sandy (very fine);

tree roots; upper $1 \mathrm{ft}$ olive gray ( $5 Y$ 4/2)

grading rapidly down to grayish yellow (5Y 7/4).....

Sand; fine to medium grading down to

medium to very coarse; poorly sorted; pale

olive gray (5Y 6/2) grading down to grayish

yellow (5Y 7/4) at about $18 \mathrm{ft}$.

\section{Tar Heel Formation}

Sand, very fine, silty, clayey, lignitic, micaceous, stiff, dense, olive-gray (5Y 4/1) 27-30

Sand, fine to medium, light-olive-gray 
Sand, very fine to fine, clayey, silty, carbonaceous; very dark dusky red (10R 2/2) with thin interbeds of very dark dusky red lignite and silty, dense clays and thin interbeds of light-olivegray $(5 Y 6.5 / 1)$, fine to medium sand

Base of dune sand:

$+87 \mathrm{ft}$ above sea level

Base of bay fill:

Base of Charles City Formation:

+79 ft above sea level

+63 ft above sea level

\section{Bottomed in Tar Heel Formation}


WL-3-07: $3.42 \mathrm{mi}$ west of eastern quadrangle border, $1.15 \mathrm{mi}$ north of southern quadrangle border, $200 \mathrm{ft}$ north of unnumbered dirt road, $0.3 \mathrm{mi}$ south of the "P" in "Mill Pond" label on map, in south-central 1/9th of map area (latitude $34.6419^{\circ} \mathrm{N}$., longitude $78.4344^{\circ} \mathrm{W}$.). Surface elevation $85 \mathrm{ft}$.

\section{LITHOLOGY}

DEPTH, IN FEET

\section{Charles City Formation}

Sand; fine to medium, dominantly fine; subrounded to rounded; clean; soft; pale yellowish brown (10YR 7/2) on dusky brown (5YR 2/2); lower contact gradational

Sand; fine to medium, dominantly fine; subrounded

to rounded; clean; soft; very humic; dark brown

(5YR 2/4); roots

Sand, fine, subangular to subrounded, humic; medium brown (5YR 4/4) grading down to

light yellowish brown (10YR 6/4)

Silt, very clayey, sandy (very fine), sticky; light olive gray (5Y 6/1) grading down to brownish gray $(5 Y R 5 / 1)$.

Peat, dark brown (5YR 2/4) grading down to grayish brown (5YR 3/2); abundant

light-brown (5YR 6/6) wood

Sand, fine to medium, subangular to subrounded, humic, slightly silty; upper foot dark yellowish gray ( $5 Y$ 6/2) then grades down rapidly to medium yellowish brown (10YR 5/4)

Sand, fine to medium, dominantly fine, subangular to subrounded, humic, slightly silty, thixotropic, medium-yellowish-brown (10YR 5/4).

\section{UNCONFORMITY}

\section{Charles City Formation}

Silt, very clayey, sandy (very fine), sticky, lightolive-gray ( $5 Y 5 / 2$ ); lower contact somewhat gradational.

Sand, fine to medium, light-olive-gray (5Y 5/2) $39-40$

(No recovery, fell off stem) $40-44$ 


\section{Tar Heel Formation}

Sand; fine to medium grading down to medium to

coarse; clayey; silty; micaceous; stiff; dense;

olive gray (5Y 4/1); sparse light-olive-brown ( $5 Y 5 / 6$ )

to dusky-yellowish-brown (10YR 2/2) lignite.

44-46

Base of dune sand:

Base of Charles City Formation:

$+55 \mathrm{ft}$ above sea level

$+41 \mathrm{ft}$ above sea level

\section{Bottomed in Tar Heel Formation}


WL-4-07: $5.31 \mathrm{mi}$ west of eastern quadrangle border, $4.27 \mathrm{mi}$ north of southern quadrangle border, along unnumbered dirt road, 1.10 mi east of junction of U.S. Highway 701 and North Carolina State Road 1519, in west-central 1/9th of map area (latitude $34.6869^{\circ} \mathrm{N}$., longitude $78.4676^{\circ} \mathrm{W}$.). Surface elevation $72 \mathrm{ft}$.

\section{LITHOLOGY}

DEPTH, IN FEET

\section{Charles City Formation}

Sand, fine to medium, subangular to subrounded, silty; dark yellowish brown (10YR 4/4) grading down through grayish orange (10YR 7/4) $(0.5-1 \mathrm{ft})$, medium yellowish brown (10YR 5/4) (1-1.5 ft), and medium brown (5YR 3/6) (1.5-2.5 ft) to yellowish gray $(5 Y 7 / 2)$ $0-3$

Sand, fine to medium, subangular to subrounded, clean, pale-grayish-orange-pink (5YR 8/2).

Sand, fine to medium, subangular to subrounded, slightly silty; pale olive gray ( $5 Y$ 7/1) grading down to brownish gray $(5 Y R$ 5/1) at $9 \mathrm{ft}$.....

Sand, very fine to fine, silty, clayey, yellowishgray $(5 Y 7 / 2)$

Sand, fine to medium, silty, clayey; varicolored, including light yellowish brown (10YR 6/4), brownish gray ( $5 Y R 5 / 2$ ), dusky brown (5YR 2/2), pale olive gray (5Y 7/1), and light yellowish gray ( $5 Y$ 8/2); lower contact gradational

Sand; medium to very coarse, dominantly medium to coarse; very poorly sorted; slightly silty; yellowish gray (5Y 7/2); scattered rounded quartz granules and pebbles up to $0.5 \mathrm{~cm}$ in length; lower contact gradational

Sand, coarse to very coarse; gravelly with subrounded to rounded quartz pebbles up to $1 \mathrm{~cm}$ in length; silty; olive gray ( $5 Y 5 / 1)$.

\section{UNCONFORMITY}

\section{Tar Heel Formation}

Silt, very clayey, sandy (very fine), micaceous, olive-gray ( $5 Y$ 4/1); 3-in.-thick piece of dark-brown (5YR 2/4) lignite and 6 -in.-thick layer of light-olive-gray ( $5 Y 5 / 2$ ), fine to medium, micaceous sand.

\section{Base of Charles City Formation:}

\section{Bottomed in Tar Heel Formation}




\section{Appendix 2. Supplementary Basement Data}

\begin{tabular}{|c|c|c|c|c|}
\hline $\begin{array}{l}\text { Basement } \\
\text { elevation } \\
\text { (in feet) }\end{array}$ & Latitude & Longitude & Well name & Data source \\
\hline-48 & $34.9917^{\circ} \mathrm{N}$. & $78.9583^{\circ} \mathrm{W}$ & CD-T-3-XX & Lawrence and Hoffman (1993). \\
\hline-98 & $34.9875^{\circ} \mathrm{N}$. & $78.7542^{\circ} \mathrm{W}$ & CD-T-3-81 & Lawrence and Hoffman (1993). \\
\hline-106 & $34.9327^{\circ} \mathrm{N}$. & $78.7392^{\circ} \mathrm{W}$ & $\begin{array}{l}\text { Cedar Creek Fire } \\
\text { Tower Station }\end{array}$ & $\begin{array}{l}\text { North Carolina Geological Survey } \\
\text { (2010). }\end{array}$ \\
\hline-110 & $34.9877^{\circ} \mathrm{N}$. & $78.7548^{\circ} \mathrm{W}$ & $\begin{array}{l}\text { Seabrook School } \\
\text { Station }\end{array}$ & $\begin{array}{l}\text { North Carolina Geological Survey } \\
\text { (2010). }\end{array}$ \\
\hline-114 & $34.8825^{\circ} \mathrm{N}$. & $78.6575^{\circ} \mathrm{W}$ & Bushy Lake Station & $\begin{array}{l}\text { North Carolina Geological Survey } \\
\text { (2010). }\end{array}$ \\
\hline-127 & $34.9581^{\circ} \mathrm{N}$. & $78.8519^{\circ} \mathrm{W}$ & Howard Williams & $\begin{array}{l}\text { North Carolina Geological Survey } \\
\text { (2010). }\end{array}$ \\
\hline-127 & $34.9581^{\circ} \mathrm{N}$. & $78.8519^{\circ} \mathrm{W}$ & CD-T-9-74 & Lawrence and Hoffman (1993). \\
\hline-134 & $34.9733^{\circ} \mathrm{N}$. & $78.8500^{\circ} \mathrm{W}$ & Jim Dozer & $\begin{array}{l}\text { North Carolina Geological Survey } \\
\text { (2010). }\end{array}$ \\
\hline-136 & $34.9869^{\circ} \mathrm{N}$. & $78.8311^{\circ} \mathrm{W}$ & Bill Devault & $\begin{array}{l}\text { North Carolina Geological Survey } \\
\text { (2010). }\end{array}$ \\
\hline-141 & $34.9525^{\circ} \mathrm{N}$. & $78.9156^{\circ} \mathrm{W}$ & CT-T-7-74 & Lawrence and Hoffman (1993). \\
\hline-206 & $4.9936^{\circ} \mathrm{N}$ & $78.3719^{\circ} \mathrm{W}$ & SA-T-2-84 & Lawrence and Hoffman (1993) \\
\hline-211 & $34.8436^{\circ} \mathrm{N}$. & $78.8383^{\circ} \mathrm{W}$ & DuPont Corporation & $\begin{array}{l}\text { North Carolina Geological Survey } \\
\text { (2010). }\end{array}$ \\
\hline-258 & $34.9994^{\circ} \mathrm{N}$. & $78.34083^{\circ} \mathrm{W}$ & SA-T-1-86 & Lawrence and Hoffman (1993). \\
\hline-279 & $34.8111^{\circ} \mathrm{N}$ & $78.3969^{\circ} \mathrm{W}$ & Garland & Trapp (1992). \\
\hline-289 & $34.9881^{\circ} \mathrm{N}$. & $78.3150^{\circ} \mathrm{W}$ & Town of Clinton & $\begin{array}{l}\text { North Carolina Geological Survey } \\
\text { (2010): }\end{array}$ \\
\hline
\end{tabular}




\section{Appendix 2. Supplementary Basement Data—Continued}

\begin{tabular}{|c|c|c|c|c|}
\hline $\begin{array}{l}\text { Basement } \\
\text { elevation } \\
\text { (in feet) }\end{array}$ & Latitude & Longitude & Well name & Data source \\
\hline-303 & $34.9753^{\circ} \mathrm{N}$ & $78.3083^{\circ} \mathrm{W}$. & Town of Clinton & $\begin{array}{l}\text { North Carolina Geological Survey } \\
\text { (2010). }\end{array}$ \\
\hline-313 & $34.9889^{\circ} \mathrm{N}$ & $78.1894^{\circ} \mathrm{W}$ & Turkey Station & $\begin{array}{l}\text { North Carolina Geological Survey } \\
\text { (2010). }\end{array}$ \\
\hline-366 & $34.6456^{\circ} \mathrm{N}$ & $78.6444^{\circ} \mathrm{W}$ & $\begin{array}{l}\text { West Point } \\
\text { Pepperell }\end{array}$ & $\begin{array}{l}\text { North Carolina Geological Survey } \\
\text { (2010). }\end{array}$ \\
\hline-371 & $34.6329^{\circ} \mathrm{N}$ & $78.6205^{\circ} \mathrm{W}$ & $\begin{array}{l}\text { Town of } \\
\text { Elizabethtown }\end{array}$ & $\begin{array}{l}\text { North Carolina Geological Survey } \\
\text { (2010). }\end{array}$ \\
\hline-372 & $34.8536^{\circ} \mathrm{N}$ & $78.2625^{\circ} \mathrm{W}$ & Six Runs Station & $\begin{array}{l}\text { North Carolina Geological Survey } \\
\text { (2010). }\end{array}$ \\
\hline-373 & $34.6478^{\circ} \mathrm{N}$ & $78.7309^{\circ} \mathrm{W}$ & Dublin Station & $\begin{array}{l}\text { North Carolina Geological Survey } \\
\text { (2010). }\end{array}$ \\
\hline-385 & $34.5700^{\circ} \mathrm{N}$ & $78.9339^{\circ} \mathrm{W}$ & VPI-2 & Lawrence and Hoffman (1993). \\
\hline-388 & $34.9283^{\circ} \mathrm{N}$ & $78.0639^{\circ} \mathrm{W}$ & DP-OT-1-69 & Lawrence and Hoffman (1993). \\
\hline-410 & $34.6553^{\circ} \mathrm{N}$ & $78.5225^{\circ} \mathrm{W}$ & $\begin{array}{l}\text { White Lake Prison } \\
\text { Station }\end{array}$ & $\begin{array}{l}\text { North Carolina Geological Survey } \\
\text { (2010). }\end{array}$ \\
\hline-415 & $34.6500^{\circ} \mathrm{N}$. & $78.5183^{\circ} \mathrm{W}$ & BL-T-1-81 & Lawrence and Hoffman (1993). \\
\hline-432 & $34.5417^{\circ} \mathrm{N}$. & $78.7917^{\circ} \mathrm{W}$. & $\begin{array}{l}\text { Town of Bladenboro } \\
\text { Test Well }\end{array}$ & $\begin{array}{l}\text { North Carolina Geological Survey } \\
\text { (2010). }\end{array}$ \\
\hline-463 & $34.5517^{\circ} \mathrm{N}$. & $78.5261^{\circ} \mathrm{W}$ & BL-244/BL-C-1-2003 & $\begin{array}{l}\text { Unpublished result from deepening } \\
\text { U.S. Geological Survey core hole } \\
\text { BL-244 in } 2004 \text {. }\end{array}$ \\
\hline-470 & $34.5068^{\circ} \mathrm{N}$. & $78.7543^{\circ} \mathrm{W}$ & Bladenboro Station & $\begin{array}{l}\text { North Carolina Geological Survey } \\
\text { (2010). }\end{array}$ \\
\hline-480 & $34.8481^{\circ} \mathrm{N}$ & $78.0217^{\circ} \mathrm{W}$ & DP-T-1-82 & Lawrence and Hoffman (1993). \\
\hline-544 & $34.6069^{\circ} \mathrm{N}$. & $78.2422^{\circ} \mathrm{W}$ & $\begin{array}{l}\text { Ivanhoe Research } \\
\text { Station }\end{array}$ & Trapp (1992). \\
\hline
\end{tabular}




\section{Appendix 3. Fossil Mollusk and Vertebrate Taxa Recovered in the Elizabethtown 1:100,000-Scale Quadrangle}

\begin{tabular}{|c|c|c|c|c|c|}
\hline Taxon & $\begin{array}{c}\text { Lumber } \\
\text { River }^{1} \\
\text { (Duplin } \\
\text { Formation) } \\
\end{array}$ & $\begin{array}{l}\text { Locality } \\
\text { WS-12 } 1 \\
\text { (Duplin } \\
\text { Formation) }\end{array}$ & $\begin{array}{l}\text { Locality } \\
\text { WS-131 } \\
\text { (Duplin } \\
\text { Formation) }\end{array}$ & $\begin{array}{l}\text { Elizabethtown } \\
\text { beds }^{2}\end{array}$ & $\begin{array}{c}\text { Locality RH- } \\
19^{1} \\
\text { (Waccamaw } \\
\text { Formation) } \\
\end{array}$ \\
\hline \multicolumn{6}{|c|}{ Pelecypoda } \\
\hline Abra aequalis & & & & $\mathrm{X}$ & \\
\hline Amusium mortoni & & & $\mathrm{X}$ & & \\
\hline Anadara aequicostata & & & & $\mathrm{X}$ & \\
\hline Anadara callicestosa & $\mathrm{X}$ & & & & \\
\hline Anadara improcera & $\mathrm{X}$ & & $\mathrm{X}$ & $\mathrm{X}$ & $\mathrm{X}$ \\
\hline Anadara lienosa & $\mathrm{X}$ & & & & \\
\hline Anadara ovalis & & & & & $\mathrm{X}$ \\
\hline Anadara propatula & $\mathrm{X}$ & & & & \\
\hline Anadara transversa & & & & & $\mathrm{X}$ \\
\hline Argopecten comparilis & $\mathrm{X}$ & & & & \\
\hline Astarte concentrica & $\mathrm{X}$ & & $\mathrm{X}$ & & \\
\hline Bornia triangula & & & & $\mathrm{X}$ & \\
\hline Carolinapecten eboreus & & $\mathrm{X}$ & $\mathrm{X}$ & $\mathrm{X}$ & $\mathrm{X}$ \\
\hline Carditamera arata & $\mathrm{X}$ & & & $\mathrm{X}$ & \\
\hline Chama corticosa & $\mathrm{X}$ & $\mathrm{X}$ & & & \\
\hline Chama emmonsi & $\mathrm{X}$ & $\mathrm{X}$ & $\mathrm{X}$ & & \\
\hline Chione cribraria & $\mathrm{X}$ & & & & \\
\hline Chione latilirata & $\mathrm{X}$ & $\mathrm{X}$ & $\mathrm{X}$ & & \\
\hline Clinocardium acutilaqueatum & $\mathrm{X}$ & & & & \\
\hline Clinocardium virginianum & $\mathrm{X}$ & & & & \\
\hline Clinocardium sp. & & $\mathrm{X}$ & & & \\
\hline Corbula cuneata & & & $\mathrm{X}$ & & \\
\hline Crassostrea virginica & $\mathrm{X}$ & & & $\mathrm{X}$ & $\mathrm{X}$ \\
\hline Crepidula aculeata aculeata & $\mathrm{X}$ & & & & \\
\hline
\end{tabular}




\section{Appendix 3. Fossil Mollusk and Vertebrate Taxa Recovered in the Elizabethtown 1:100,000-Scale Quadrangle-Continued}

\begin{tabular}{|c|c|c|c|c|c|}
\hline Taxon & $\begin{array}{c}\text { Lumber } \\
\text { River }^{1} \\
\text { (Duplin } \\
\text { Formation) }\end{array}$ & $\begin{array}{l}\text { Locality } \\
\text { WS-12 } \\
\text { (Duplin } \\
\text { Formation) }\end{array}$ & $\begin{array}{l}\text { Locality } \\
\text { WS-131 } \\
\text { (Duplin } \\
\text { Formation) }\end{array}$ & $\begin{array}{l}\text { Elizabethtown } \\
\text { beds }^{2}\end{array}$ & $\begin{array}{c}\text { Locality RH- } \\
19^{1} \\
\text { (Waccamaw } \\
\text { Formation) } \\
\end{array}$ \\
\hline \multicolumn{6}{|c|}{ Pelecypoda-continued } \\
\hline Crepidula aculeata costata & $\mathrm{X}$ & & & & \\
\hline Crepidula cymbaeformis & & $\mathrm{X}$ & & & \\
\hline Crepidula fornicata & $\mathrm{X}$ & & & & \\
\hline Crepidula plana & $\mathrm{X}$ & $\mathrm{X}$ & & & \\
\hline Crucibulum grandis & $\mathrm{X}$ & & & & \\
\hline Ctena speciosa & & $?$ & ? & & \\
\hline Cumingia subtellinoides & & & & $\mathrm{X}$ & \\
\hline Cyathodonta dalli & & $\mathrm{X}$ & & & \\
\hline Diplodonta acclinis & & & & $\mathrm{X}$ & \\
\hline Divaricella quadrisulcata & & & & $\mathrm{X}$ & \\
\hline Donax cuneola & & & & $\mathrm{X}$ & \\
\hline Dosinia acetabula & $\mathrm{X}$ & & & & \\
\hline Dosinia elegans & & & & $\mathrm{X}$ & \\
\hline Ensis directus & $\mathrm{X}$ & & & $\mathrm{X}$ & \\
\hline Ensis sp. & & & $\mathrm{X}$ & & $\mathrm{X}$ \\
\hline Eucrassatella kauffmani & $\mathrm{X}$ & & & & \\
\hline Eucrassatella virginica & & & $\mathrm{X}$ & & \\
\hline Florimetis magnoliana & $\mathrm{X}$ & & & & \\
\hline Gemma magna & & & & $\mathrm{X}$ & \\
\hline Glycymeris americana & $\mathrm{X}$ & & & $\mathrm{X}$ & \\
\hline Glycymeris americana quinquerugata & & $\mathrm{X}$ & $\mathrm{X}$ & & \\
\hline Glycymeris subovata & $\mathrm{X}$ & $\mathrm{X}$ & $\mathrm{X}$ & $\mathrm{X}$ & \\
\hline Glycymeris subovata var. hummi & & & & $\mathrm{X}$ & \\
\hline Gouldia metastriata & $\mathrm{X}$ & & & & \\
\hline
\end{tabular}




\section{Appendix 3. Fossil Mollusk and Vertebrate Taxa Recovered in the Elizabethtown 1:100,000-Scale Quadrangle-Continued}

\begin{tabular}{|c|c|c|c|c|c|}
\hline Taxon & $\begin{array}{c}\text { Lumber } \\
\text { River }^{1} \\
\text { (Duplin } \\
\text { Formation) }\end{array}$ & $\begin{array}{l}\text { Locality } \\
\text { WS-12 } \\
\text { (Duplin } \\
\text { Formation) }\end{array}$ & $\begin{array}{c}\text { Locality } \\
\text { WS-13 }^{1} \\
\text { (Duplin } \\
\text { Formation) }\end{array}$ & $\begin{array}{c}\text { Elizabethtown } \\
\text { beds }^{2}\end{array}$ & $\begin{array}{c}\text { Locality RH- } \\
19^{1} \\
\text { (Waccamaw } \\
\text { Formation) }\end{array}$ \\
\hline \multicolumn{6}{|c|}{ Pelecypoda—continued } \\
\hline Macrocallista albraria & & $\mathrm{X}$ & & & \\
\hline Macrocallista greeni & & & & $\mathrm{X}$ & \\
\hline Mercenaria campechiensis campechiensis & & & & $\mathrm{X}$ & \\
\hline Mercenaria corrugata & $\mathrm{X}$ & & & & \\
\hline Merceneria tridachnoides & $\mathrm{X}$ & & & & \\
\hline Merceneria sp. & & & $\mathrm{X}$ & & \\
\hline Modiolus gigas & & & $\mathrm{X}$ & & \\
\hline Mulinia congesta & & $\mathrm{X}$ & $\mathrm{X}$ & & $\mathrm{X}$ \\
\hline Mulinia lateralis & & & & $\mathrm{X}$ & $\mathrm{X}$ \\
\hline Noetia carolinensis & & & & $\mathrm{X}$ & \\
\hline Noetia limula & & & & $\mathrm{X}$ & \\
\hline Nucula proxima & & & & $\mathrm{X}$ & \\
\hline Nucula taphria & & & & $\mathrm{X}$ & \\
\hline Nuculana acuta & & & & $\mathrm{X}$ & \\
\hline Nuculana hypsoma & & & & & $\mathrm{X}$ \\
\hline Nuculana sp. & & & & & $\mathrm{X}$ \\
\hline Ostrea compressirostra & & & $\mathrm{X}$ & $\mathrm{X}$ & $\mathrm{X}$ \\
\hline Ostrea sculpturata & $\mathrm{X}$ & & & $\mathrm{X}$ & \\
\hline Panopea reflexa & $\mathrm{X}$ & & & & \\
\hline Parvilucina crenulata & & & & $\mathrm{X}$ & \\
\hline Parvilucina multilineata & & & & $\mathrm{X}$ & \\
\hline Parvilucina (Cavilinga) trisulcata & & & & $\mathrm{X}$ & \\
\hline Pecten hemicyclicus & $\mathrm{X}$ & & & & \\
\hline Placunanomia plicata (thick form) & & & & $\mathrm{X}$ & \\
\hline
\end{tabular}




\section{Appendix 3. Fossil Mollusk and Vertebrate Taxa Recovered in the Elizabethtown 1:100,000-Scale Quadrangle-Continued}

\begin{tabular}{|c|c|c|c|c|c|}
\hline Taxon & $\begin{array}{c}\text { Lumber } \\
\text { River }^{1} \\
\text { (Duplin } \\
\text { Formation) }\end{array}$ & $\begin{array}{l}\text { Locality } \\
\text { WS-12 } \\
\text { (Duplin } \\
\text { Formation) }\end{array}$ & $\begin{array}{c}\text { Locality } \\
\text { WS-13 }^{1} \\
\text { (Duplin } \\
\text { Formation) }\end{array}$ & $\begin{array}{c}\text { Elizabethtown } \\
\text { beds }^{2}\end{array}$ & $\begin{array}{c}\text { Locality RH- } \\
19^{1} \\
\text { (Waccamaw } \\
\text { Formation) }\end{array}$ \\
\hline \multicolumn{6}{|c|}{ Pelecypoda—continued } \\
\hline Pleuromeris decemcostata & & & & & $\mathrm{X}$ \\
\hline Pleuromeris tridentata & $\mathrm{X}$ & & & & \\
\hline Plicatula marginata & $\mathrm{X}$ & $\mathrm{X}$ & $\mathrm{X}$ & $\mathrm{X}$ & \\
\hline Pododesmus sp. & $\mathrm{X}$ & & & & \\
\hline Pseudomiltha anodonta & & & & $\mathrm{X}$ & \\
\hline Quadrilatera adamsi & & & & $\mathrm{X}$ & \\
\hline Raeta plicatella & & & & $\mathrm{X}$ & \\
\hline Rangia clathrodonta & & & & $\mathrm{X}$ & \\
\hline Semele carinata & & $\mathrm{X}$ & & $\mathrm{X}$ & \\
\hline Sphenia dubia & & & & $\mathrm{X}$ & \\
\hline Spisula confraga & $\mathrm{X}$ & & & & \\
\hline Strigilla mirabilis & & & & $\mathrm{X}$ & \\
\hline Tagelus plebeius & & & & $\mathrm{X}$ & \\
\hline Yoldia laevis & & & & $\mathrm{X}$ & \\
\hline \multicolumn{6}{|c|}{ Gastropoda } \\
\hline Busycon contrarium & & & & $\mathrm{X}$ & \\
\hline Busycon excavatum & & & & $\mathrm{X}$ & \\
\hline Busycon incile & $\mathrm{X}$ & & & & \\
\hline Busycon maximum maximum & & & & $\mathrm{X}$ & \\
\hline Busycon maximum filosum & $\mathrm{X}$ & & & & \\
\hline Busycon sp. & & $\mathrm{X}$ & & & $\mathrm{X}$ \\
\hline Caecum compactum & & & & $\mathrm{X}$ & \\
\hline Caecum johnsoni & & & & $\mathrm{X}$ & \\
\hline Calliostoma lapidosum & $\mathrm{X}$ & & & & \\
\hline
\end{tabular}




\section{Appendix 3. Fossil Mollusk and Vertebrate Taxa Recovered in the Elizabethtown 1:100,000-Scale Quadrangle-Continued}

\begin{tabular}{|c|c|c|c|c|c|}
\hline Taxon & $\begin{array}{c}\text { Lumber } \\
\text { River }^{1} \\
\text { (Duplin } \\
\text { Formation) } \\
\end{array}$ & $\begin{array}{l}\text { Locality } \\
\text { WS-12 } \\
\text { (Duplin } \\
\text { Formation) }\end{array}$ & $\begin{array}{c}\text { Locality } \\
\text { WS-13 }^{1} \\
\text { (Duplin } \\
\text { Formation) }\end{array}$ & $\begin{array}{c}\text { Elizabethtown } \\
\text { beds }^{2}\end{array}$ & $\begin{array}{c}\text { Locality RH- } \\
19^{1} \\
\text { (Waccamaw } \\
\text { Formation) }\end{array}$ \\
\hline \multicolumn{6}{|c|}{ Gastropoda—continued } \\
\hline Calyptraea centralis & $\mathrm{X}$ & & & & \\
\hline Conus marylandicus & $\mathrm{X}$ & & & & \\
\hline Conus adversarius & $\mathrm{X}$ & & & & \\
\hline Crassispira virginiana & & $\mathrm{X}$ & & & \\
\hline Crepidula fornicata & & & & $\mathrm{X}$ & \\
\hline Crepidula sp. & & & & & $\mathrm{X}$ \\
\hline Crucibulum scutellatum & $\mathrm{X}$ & & & & \\
\hline Cyclostremiscus obliquestriatus & & & & $\mathrm{X}$ & \\
\hline Cymatosyrinx lunata & $\mathrm{X}$ & & & $\mathrm{X}$ & \\
\hline Diodora sp. & $\mathrm{X}$ & & & & \\
\hline Drillia impressa & & $\mathrm{X}$ & & & \\
\hline Epitonium rupicolum & & & & $\mathrm{X}$ & \\
\hline Eupleura caudata & & & & $\mathrm{X}$ & \\
\hline Euspira sayana & $\mathrm{X}$ & & & & \\
\hline Fusinus exilis exilis & $\mathrm{X}$ & & & & \\
\hline Fusinus exilis burnsii & $\mathrm{X}$ & & & & \\
\hline Hesperisternia filicata & ? & & & & \\
\hline Ilyanassa porcina & $\mathrm{X}$ & & & & \\
\hline Littorina irrorata carolinensis & & & & $\mathrm{X}$ & \\
\hline Lunatia interna & & & $\mathrm{X}$ & & \\
\hline Mitrella lunata & & & & $\mathrm{X}$ & \\
\hline Nassarius quadrulatus & $\mathrm{X}$ & $\mathrm{X}$ & & $\mathrm{X}$ & \\
\hline Oliva canaliculata & $\mathrm{X}$ & $\mathrm{X}$ & & & \\
\hline Olivella mutica & $\mathrm{X}$ & $\mathrm{X}$ & & $\mathrm{X}$ & \\
\hline
\end{tabular}




\section{Appendix 3. Fossil Mollusk and Vertebrate Taxa Recovered in the Elizabethtown 1:100,000-Scale Quadrangle-Continued}

\begin{tabular}{|c|c|c|c|c|c|}
\hline Taxon & $\begin{array}{c}\text { Lumber } \\
\text { River }^{1} \\
\text { (Duplin } \\
\text { Formation) }\end{array}$ & $\begin{array}{l}\text { Locality } \\
\text { WS-12 } \\
\text { (Duplin } \\
\text { Formation) }\end{array}$ & $\begin{array}{c}\text { Locality } \\
\text { WS-13 }{ }^{1} \\
\text { (Duplin } \\
\text { Formation) }\end{array}$ & $\begin{array}{c}\text { Elizabethtown } \\
\text { beds }^{2}\end{array}$ & $\begin{array}{c}\text { Locality RH- } \\
19^{1} \\
\text { (Waccamaw } \\
\text { Formation) }\end{array}$ \\
\hline \multicolumn{6}{|c|}{ Gastropoda-continued } \\
\hline Petaloconchus sculpturatus & $\mathrm{X}$ & $\mathrm{X}$ & $\mathrm{X}$ & & \\
\hline Polinices duplicatus & & & $\mathrm{X}$ & & \\
\hline Prunum limatulum & $\mathrm{X}$ & $\mathrm{X}$ & $\mathrm{X}$ & $\mathrm{X}$ & $\mathrm{X}$ \\
\hline Prunum virginianum & & $\mathrm{X}$ & & & \\
\hline Ptychosalpinx multirugata & $\mathrm{X}$ & & & & \\
\hline Ptychosalpinx tuomeyi & & $\mathrm{X}$ & & & \\
\hline Scalaspira sp. & & & & & ? \\
\hline Serpulorbis granifera & $\mathrm{X}$ & & & & \\
\hline Skenea harrisii & & & & $\mathrm{X}$ & \\
\hline Tectonatica pusilla & & & & $\mathrm{X}$ & \\
\hline Teinostoma nana & & & & $\mathrm{X}$ & \\
\hline Terebra blakei & $\mathrm{X}$ & & & & \\
\hline Terebra emmonsii emmonsii & $\mathrm{X}$ & & & & \\
\hline Terebra emmonsii grayi & $\mathrm{X}$ & & & & \\
\hline Terebra emmonsii hamptonensis & $\mathrm{X}$ & & & & \\
\hline Terebra sp. & & $\mathrm{X}$ & & & $\mathrm{X}$ \\
\hline Triplofusus gigantea & $\mathrm{X}$ & & & & \\
\hline Turritella alticostata & ? & & & & \\
\hline Turritella fluxionalis & $\mathrm{X}$ & & & & \\
\hline Turritella virginica & $\mathrm{X}$ & & & & \\
\hline Turritella sp. & & $\mathrm{X}$ & $\mathrm{X}$ & & \\
\hline Urosalpinx lepidota & $\mathrm{X}$ & & & $\mathrm{X}$ & \\
\hline
\end{tabular}




\section{Appendix 3. Fossil Mollusk and Vertebrate Taxa Recovered in the Elizabethtown 1:100,000-Scale Quadrangle-Continued}

\begin{tabular}{|c|c|c|c|c|c|}
\hline Taxon & $\begin{array}{c}\text { Lumber } \\
\text { River }^{1} \\
\text { (Duplin } \\
\text { Formation) }\end{array}$ & $\begin{array}{l}\text { Locality } \\
\text { WS-12 } 1 \\
\text { (Duplin } \\
\text { Formation) }\end{array}$ & $\begin{array}{l}\text { Locality } \\
\text { WS-13 } 1 \\
\text { (Duplin } \\
\text { Formation) }\end{array}$ & $\begin{array}{c}\text { Elizabethtown } \\
\text { beds }^{2}\end{array}$ & $\begin{array}{c}\text { Locality RH- } \\
19^{1} \\
\text { (Waccamaw } \\
\text { Formation) } \\
\end{array}$ \\
\hline \multicolumn{6}{|c|}{ Selachii } \\
\hline Squalicorax kaupi ${ }^{3}$ & $\mathrm{X}$ & $\mathrm{X}$ & & & \\
\hline Squalicorax pristodontus ${ }^{3}$ & $\mathrm{X}$ & & & & \\
\hline
\end{tabular}

${ }^{1}$ Collection reposited with the North Carolina Museum of Natural Sciences, Raleigh, N.C., under accession number 12351.

${ }^{2}$ Faunal list compiled by Campbell (1993), which also provides a comprehensive list of species from elsewhere in the Duplin and Waccamaw Formations.

${ }^{3}$ Specimens reworked into base of Duplin Formation from Tar Heel Formation below. 


\section{Appendix 4. Upper Cretaceous Fossil Vertebrate Taxa Reported by Miller (1966, 1967, 1968), Baird and Horner (1979), and Robb (1989) From Phoebus Landing in the Elizabethtown 1:100,000-Scale Quadrangle}

\begin{tabular}{ll}
\hline \multicolumn{1}{c}{ Taxon } & Affinity \\
\hline Hybodus montanensis & Chondrichthyes \\
Ischyrhiza mira & Hybodont shark \\
Odontaspis samhammeri & Ganopristine shark \\
Scapanorhynchus texanus & Sand shark \\
Squalicorax kaupi & Goblin shark \\
Squalicorax pristodontus & Crow shark \\
Squatina hassei & Crow shark \\
Synodontaspis holmdelensis & Angel shark \\
Brachyrhizodus wichitaensis & Sand shark \\
Rhombodus levis & Cow-nosed ray \\
Ischyodus cf. I. bifurcatus & Primitive ray \\
\hline
\end{tabular}

Osteichthyes

$\begin{array}{ll}\text { Albula sp. } & \text { Bonefish } \\ \text { Anomoeodus phaseolus } & \text { Pycnodont fish } \\ \text { Cylindracanthus ornatus } & \text { Affinity uncertain } \\ \text { Enchodus cf. E. petrosus } & \text { Primitive salmon } \\ \text { Lepisosteidae indet. } & \text { Garfish } \\ \text { Paralbula casei } & \text { Primitive ladyfish } \\ \text { Saurodon sp. } & \text { Osteoglossomorph fish } \\ \text { Stephanodus sp. } & \text { Triggerfish } \\ \text { Xiphactinus audax } & \text { Primitive tarpon }\end{array}$

Reptilia

Adocus sp.

Soft-shell turtle

Bothremys barberi

Side-neck turtle 


\section{Appendix 4. Upper Cretaceous Fossil Vertebrate Taxa Reported by Miller (1966, 1967, 1968), Baird and Horner (1979), and Robb (1989) From Phoebus Landing in the Elizabethtown 1:100,000-Scale Quadrangle-Continued}

\begin{tabular}{ll}
\hline \multicolumn{1}{c}{ Taxon } & \multicolumn{1}{c}{ Affinity } \\
\hline & Reptilia—continued \\
\hline Brachychampsa sp. & Alligatorid crocodilian \\
$c f$. Thoracosaurus neocessariensis & Gavialid crocodilian \\
Deinosuchus rugosus & Alligatorid crocodilian \\
Dryptosaurus sp. & Theropod dinosaur \\
Hadrosaurinae indet. & Medium-sized hadrosaur \\
Halosaurus sp. & Mosasaur \\
Hypsibema crassicauda & Giant hadrosaur \\
Leidyosuchus $c f$. L. formidabilis & Alligatorid crocodilian \\
Ornithomimus sp. & Theropod dinosaur \\
Platecarpus sp. & Mosasaur \\
Prognathodon sp. & Mosasaur \\
Taphrosphys dares & Side-neck turtle \\
Trionyx halophilus & Soft-shell turtle \\
Tylosaurus sp. & Mosasaur \\
\hline
\end{tabular}


Manuscript approved on May 5, 2011.

For more information about this publication, contact

Chief, Eastern Geology and Paleoclimate Science Center

U.S. Geological Survey

12201 Sunrise Valley Drive, MS 926A

Reston, VA 20192

Edited by Elizabeth D. Koozmin and Lyn K. Osburn

Layout by Cathy Y. Knutson

Online Posting by Cathy Y. Knutson 